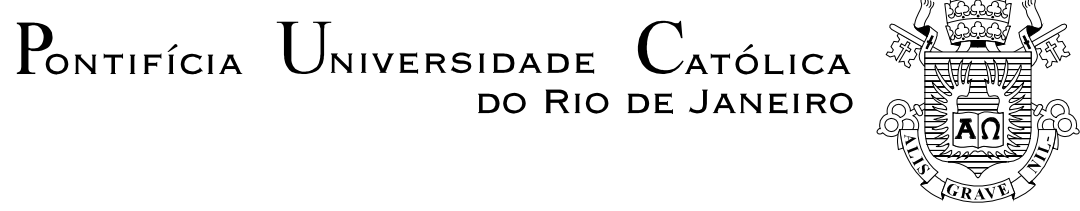

THIAGO GUERRA

\title{
MODELAGEM DO CICLO TÉRMICO DO PROCESSO GMAW EM AÇOS INOXIDÁVEIS DUPLEX PELO MÉTODO DE ELEMENTOS FINITOS
}

\section{Tese de Doutorado}

Tese apresentada ao Programa de Pós-graduação em Engenharia de Materiais e de Processos Químicos e Metalúrgicos da PUC-Rio como requisito parcial para obtenção do grau de Doutor em Engenharia de Materiais e de Processos Químicos e Metalúrgicos.

Orientador: Profa. Ivani de Souza Bott

Co-orientador: Prof. Pedro Manuel Calas Lopes Pacheco

Rio de Janeiro

Setembro de 2017 


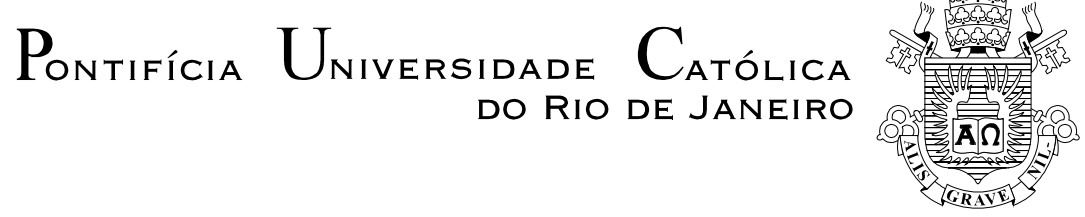

THIAGO GUERRA

\title{
MODELAGEM DO CICLO TÉRMICO DO PROCESSO GMAW EM AÇOS INOXIDÁVEIS DUPLEX PELO MÉTODO DE ELEMENTOS FINITOS
}

\author{
Tese apresentada como requisito parcial para \\ obtenção do grau de Doutor pelo Programa de Pós- \\ Graduação em Engenharia de Materiais e de \\ Processos Químicos e Metalúrgicos da PUC-Rio. \\ Aprovada pela Comissão Examinadora abaixo \\ assinada.
}

Profa. Ivani de Souza Bott

Orientador

Departamento de Engenharia Química e de Materiais - PUC-Rio

Prof. Pedro Manuel Calas Lopes Pacheco

Co-Orientador

CEFET/RJ

Prof. Luis Felipe Guimarães de Souza

CEFET/RJ

Prof. Jorge Carlos Ferreira Jorge

CEFET/RJ

Prof. Sérgio Souto Maior Tavares

Departamento de Engenharia Mecânica - UFF

Prof. Leonardo Sales Araújo

COPPE/UFRJ

Prof. Marcio da Silveira Carvalho

Coordenador Setorial de Pós-Graduação do Centro Técnico

Científico da PUC-Rio

Rio de Janeiro, 22 de Setembro de 2017. 
Todos os direitos reservados. É proibida a reprodução total ou parcial do trabalho sem autorização do autor, da orientadora e da universidade.

\section{Thiago Guerra}

Bacharel em Física, pela Universidade Federal de Santa Maria RS (2008), mestre em Engenharia de Defesa pelo Instituto Militar de Engenharia (2011) na área de simulação de processos catalíticos com explosivos e Ã (c) Doutor em Engenharia de Materiais e de Processos Químicos e Metalúrgicos pela Pontifícia Universidade Católica do Rio de Janeiro (2017), na área de simulação numérica e soldagem de aços inoxidáveis duplex. Tem experiência na Área de Física e Engenharia de Materiais, com ênfase em materiais metálicos, atuando principalmente nos seguintes temas: análises microestruturais de aços inoxidáveis duplex, propriedades mecânicas e termo dependentes de materiais metálicos e simulações numéricas.

Ficha Catalográfica

Guerra, Thiago

Modelagem do ciclo térmico do processo GMAW em aços inoxidáveis duplex pelo método de elementos finitos / Thiago Guerra; orientador: Ivani de Souza Bott; co-orientador: Pedro Manuel Calas Lopes Pacheco. - 2017.

$144 \mathrm{f.} \mathrm{;} 30 \mathrm{~cm}$

Tese (doutorado) - Pontifícia Universidade Católica do Rio de Janeiro, Departamento de Engenharia Química e de Materiais, 2017.

Inclui bibliografia

1. Engenharia de Materiais - Teses. 2. Engenharia Química - Teses. 3. Modelamento. 4. Aço inoxidável duplex. 5. Simulação física. 6. ZTA. I. Bott, Ivani de Souza. II. Pacheco, Pedro Manuel Calas Lopes. III. Pontifícia Universidade Católica do Rio de Janeiro. Departamento de Engenharia Química e de Materiais. IV. Título. 
Tos meus pais...

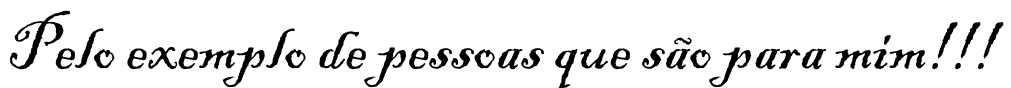




\section{Agradecimentos}

Primeiramente a Deus, que no meio de tantas tribulações, permitiu que este trabalho fosse executado.

À minha orientadora, Professora Ivani de S. Bott, por todo conhecimento e tempo compartilhados, dedicação e compreensão, reuniões e atenção durante toda realização do trabalho, meu especial agradecimento.

Igualmente ao meu orientador, Pedro Manuel, por todo conhecimento e tempo dedicado ao ensino da metodologia, paciência nas explicações, dedicação e atenção para a realização deste trabalho, também o meu agradecimento especial.

Aos meus pais, por todo apoio prestado, principalmente nas horas mais difíceis, ao meu irmão pelas conversas e idas ao RIR, e a todos os familiares, que deram seu suporte e colaboração, no intuito de concretizar esse sonho.

Aos professores Luis Felipe, Jorge e Mateus do CEFET, por toda atenção dedicada na realização dos experimentos e discussão do trabalho.

Aos meus colegas da PUC: Lilia, Marina, Asafe e Henrique e de também de fora da PUC, Guilherme e Luciano, sempre a disposição para ajudar.

Aos colegas Hiron e Marcelo do CEFET, pelas grandes contribuições na realização dos experimentos.

Juan Pozo e Amado Cruz por toda solicitude no auxílio com as dúvidas e na realização do trabalho.

Aos professores da PUC-Rio, por suas ótimas aulas lecionadas. Em especial ao professor Sidnei, sendo de fundamental importância para a realização deste trabalho. A Carmem por todo auxílio prestado na PUC.

Aos meus colegas de apartamento, Fábio, Lúcio, Danyllo, Pablo, Juninho, Raul, Rubens e Daniel, que ajudaram com horas de conversas e incentivos, assim como a todos os colegas de classe que participaram de maneira direta ou indireta, fica registrado meu agradecimento.

À PUC-Rio, ao Departamento de Engenharia Química e de Materiais, à Coordenação de Aperfeiçoamento de Pessoal de Nível Superior (CAPES) e ao Conselho Nacional de Desenvolvimento Científico e Tecnológico pelo financiamento outorgado para a realização de meus estudos de doutorado. 


\section{Resumo}

Guerra, Thiago; Bott, Ivani de Souza (Orientador); Pacheco, Pedro Manuel Calas Lopes (Co-orientador). Modelagem do ciclo térmico do processo GMAW em aços inoxidáveis duplex pelo método de elementos finitos. Rio de Janeiro, 2018. 144p. Tese de Doutorado - Departamento de Engenharia Química e de Materiais, Pontifícia Universidade Católica do Rio de Janeiro.

Os aços inoxidáveis Duplex são materiais metálicos que tendem a aliar uma excelente resistência à corrosão em meios agressivos com elevada resistência mecânica devido à sua microestrutura bifásica. Essa microestrutura é composta por uma matriz ferrítica e ilhas de austenita, a temperatura ambiente, com frações volumétricas aproximadamente iguais dessas duas fases. Com isso, estas ligas costumam ser utilizadas em tubulações e equipamentos industriais onde se requer elevada relação resistência/peso, especialmente em empreendimentos de construção e montagem off-shore. Este trabalho apresenta uma metodologia desenvolvida com a utilização de um modelo numérico parametrizado baseado no método de elementos finitos para analisar o efeito dos ciclos térmicos de soldagem nos aços duplex e leanduplex. O modelo desenvolvido faz uso da análise térmica transiente da soldagem, em que as propriedades térmicas dos materiais envolvidos são termo dependentes, e grandes gradientes térmicos são gerados entre a região da solda e as áreas afastadas dela. Procedimentos experimentais para medição dos ciclos térmicos empregados sob determinados regimes de soldagem são utilizados para calibrar o modelo numérico. A metodologia é aplicada ao estudo do comportamento de uma solda na forma de cordão sob chapa contendo um único passe, realizada com o processo GMAW, em chapas planas de 10mm de espessura dos aços duplex UNS32205 e leanduplex UNS32304, através de um modelo de elementos finitos. Os resultados mostram uma boa correspondência entre o modelo numérico e o resultado experimental.

\section{Palavras-chave}

Modelamento; Aço Inoxidável Duplex; Simulação Física; ZTA. 


\section{Abstract}

Guerra, Thiago; Bott, Ivani de Souza (Advisor); Pacheco, Pedro Manuel Calas Lopes (Co-advisor). Modelling of the Gmaw process thermal cycle in duplex stainless steel using finite elements method. Rio de Janeiro, 2018. 144p. Tese de Doutorado - Departamento de Engenharia Química e de Materiais, Pontifícia Universidade Católica do Rio de Janeiro.

Duplex stainless steels are metallic materials that tend to combine excellent corrosion resistance in aggressive environment with high mechanical strength due to their biphasic microstructure. This microstructure is composed of a ferritic matrix and austenite islands, at room temperature, with approximately equal volume fractions of these two phases. As a result, these alloys are often used in pipes and industrial equipment where high resistance / weight ratio is required, especially in offshore assembly and construction field. This work presents a methodology developed with the use of a parameterized numerical model based on the finite element method to analyze the effect of thermal welding cycles on duplex and leanduplex stainless steels. The developed model uses the transient thermal analysis of welding, in which the thermal properties of the materials involved are thermo-dependent, and large thermal gradients are generated between the region of the weld and the areas away from it. Experimental procedures for measuring the thermal cycles employed under certain welding conditions are used to calibrate the numerical model. The methodology is applied to the study of the behavior of a weld in the form of a strand in sheet form containing a single pass, realized with the GMAW process, in flat plates of $10 \mathrm{~mm}$ thickness of the duplex steels UNS32205 and leanduplex UNS32304, through a finite element model. The results show a good correspondence between the numerical model and the experimental result.

\section{Keywords}

Numerical simulation; duplex stainless steel; HAZ. 


\section{Sumário}

$\begin{array}{ll}\text { 1. Introdução } & 18\end{array}$

2. Objetivos 20

3. Revisão Bibliográfica $\quad 21$

3.1. Breve História dos Aços Inoxidáveis Duplex 21

3.2. Características dos aços inoxidáveis duplex $\quad 24$

3.2.1. Microestrutura 25

3.2.2. Propriedades Físicas $\quad 29$

3.2.3. Propriedades Mecânicas 31

3.3. Soldagem dos Aços Inoxidáveis Duplex 32

3.4. Ciclos Térmicos 34

3.5. Partição Térmica 36

3.6. Metalurgia da soldagem dos aços inoxidáveis duplex26 37

3.6.1. Influência dos Elementos de Liga na Microestrutura da Junta Soldada $\quad 37$

3.7. Características e microestrutura dos AID durante o processo de soldagem 41

3.7.1. Influência das taxas de resfriamento sobre as transformações nos aços inox duplex $\quad 42$

3.7.2. Zona Termicamente Afetada (ZTA) 44

3.7.2.1 Zona Termicamente Afetada de Temperatura Elevada (ZTATE) 45

3.7.2.2 Zona Termicamente Afetada de Temperatura Baixa (ZTATB) 49

3.7.3. Controlando as Frações Ferrita - Austenita 51

3.7.4. Metal de Solda $\quad 51$

4. Modelagem do Processo de Soldagem - Aproximações 53

4.1. Modelo da Fonte de Calor - Introdução $\quad 54$

4.1.1. Modelo da Fonte de Calor Duplo Elipsoide de Goldak 59

4.1.2. Geração da malha do modelo x Tempo computacional 60

4.1.3. Passo de Tempo 61

4.1.4. Condições de Perda de Calor 62

4.1.4.1. Condução 62

4.1.4.2. Convecção 63

4.1.4.3. Radiação 64

4.1.4.4 Coeficiente de transferência de calor combinado 64

5. Modelo Numérico Desenvolvido $\quad 66$

5.1. Descrição da Geometria 66

5.2. Condições de Contorno 69

$\begin{array}{ll}\text { 5.3. Modelo do Cordão de Solda } & 70\end{array}$

5.4. Análise Térmica 71

5.5. Propriedades Físicas Utilizadas nos Modelos Numéricos 73

6. Materiais e Métodos Experimentais $\quad \mathbf{8 0}$

6.1. Materiais Utilizados $\quad 80$ 
6.1.1. Metal Base $\quad 80$

6.1.2. Consumíveis de Soldagem 80

6.2. Preparação dos Corpos de Prova 81

6.3. Soldagem $\quad 83$

6.4. Medição dos Ciclos Térmicos 86

6.5. Análises Macrográficas da Solda $\quad 87$

6.5.1. Contagem de Fases $\quad 87$

7. Resultados e Discussão $\quad 88$

7.1. Ensaios Experimentais $\quad 88$

7.1.1. Medição dos Ciclos Térmicos Através dos Termopares 88

7.1.2. Análise Metalográfica 93

7.2. Simulações Numéricas 95

7.2.1. Efeito de Borda 96

7.2.2. Validação do Modelo Numérico 103

7.2.3. Calibração dos Modelos 104

7.2.3.1. Amostras Aporte Térmico Menor - 1,5kJ/mm 105

7.2.3.2. Amostras Aporte Térmico Maior - 2,5kJ/mm 110

7.3. Ciclos Térmicos Simulados x Microestrutura 119

7.3.1. Amostras Aporte Térmico Maior - 2,5kJ/mm 121

7.3.2. Amostras Aporte Térmico Maior - 1,5kJ/mm 127

$\begin{array}{ll}\text { 8. Conclusão } & 133\end{array}$

9. Sugestão para Trabalhos Futuros 135

10. Referências Bibliográficas 136 


\section{Lista de figuras}

Figura 3.1: Microestrutura típica do aço inoxidável duplex, mostrando a estrutura lamelar com matriz ferrítica com ilhas de austenita.

Figura 3.2: Seção isotérmica do sistema ternário $\mathrm{Fe}-\mathrm{Cr}-\mathrm{Ni}$ a $1300^{\circ} \mathrm{C}$ (RAYNOR, 1988).

Figura 3.3: Seção isotérmica do sistema ternário Fe-Cr-Ni a $1200^{\circ} \mathrm{C}$ (RAYNOR, 1988).

Figura 3.4: Seção isotérmica do sistema ternário Fe-Cr-Ni a $1100^{\circ} \mathrm{C}$ (RAYNOR, 1988).

Figura 3.5: Seção isotérmica do sistema ternário Fe-Cr-Ni a $1000^{\circ} \mathrm{C}$ (RAYNOR, 1988).

Figura 3.6: Diagrama pseudo-binário (70\% Fe em peso) do sistema FeCr-Ni (ATAMERT*, 1991).

Figura 3.7: (a) Curva esquemática de um ciclo térmico; (b) Variações de temperatura ao longo de uma junta (ZEEMANN, 2001).

Figura 3.8: Desenho mostrando a repartição térmica para um determinado cordão de solda, evidenciando três regiões da solda. Região A - Zona Fundida (ZF); Região B - Zona Termicamente Afetada (ZTA); Região C - Metal de Base (MB) (MARQUES, 2007).

Figura 3.9: Influência do teor de cromo na taxa de corrosão de uma liga Fe-Cr (MODENESI, 2001).

Figura 3.10: Curvas TTP para a precipitação de fases intermetálicas em um AID UNS S31803 solubilizado a $1050^{\circ} \mathrm{C}$ por $30 \mathrm{~min}$ (SEDRIKS, 1996).

Figura 3.11: Diagrama esquemático exibindo as mudanças na estrutura de uma junta soldada de um AID submetido a um processo de soldagem (ATAMERT, 1992).

Figura 3.12: Imagem de um aço inoxidável duplex, destacando a região que foi afetada pelo calor de um processo de soldagem.

Figura 3.13: Regiões de um ciclo térmico de soldagem da ZTATE (VAROL, 1992). 
Figura 3.14: Efeito do aporte térmico (tempo acima da temperatura solvus da ferrita) no tamanho de grão da ferrita (Lippold et al., 1994 adaptado).

Figura 3.15: Distintos casos mostrando regiões relevantes de um ciclo térmico de soldagem na ZTATB. (a) Quando a temperatura máxima ultrapassa $(T \alpha / \gamma)$ e (b) quando a temperatura máxima está determinada dentro do intervalo de precipitação de uma fase deletéria.

Figura 3.16: Imagem de um aço inoxidável duplex, ilustrando a separação adotada para a ZTA, em temperatura alta (região com crescimento de grão) e temperatura baixa (desbalanço das frações de fase).

Figura 4.1: Representação do sistema de coordenadas para obtenção do sistema quase-estacionário.

Figura 4.2: Distribuição Gaussiana do fluxo de calor gerado no processo de soldagem sugerido por Eagar e Tsai (EAGAR e TSAI, 1983).

Figura 4.3: Modelo de distribuição de calor apresentada por Goldak (GOLDAK, 1983).

Figura 5.1: Key-points onde as áreas serão atribuídas.

Figura 5.2: Exemplo das geometrias expandidas utilizadas nos modelos numéricos; a) 150x300x10mm; b) 150x150x10mm.

Figura 5.3: Exemplo da chapa, considerando a condição de simetria proposta.

Figura 5.4: Condições de contorno convectivas no modelo axissimétrico.

Figura 5.5: Visão lateral da malha utilizada no modelo axissimétrico.

Figura 5.6: Ampliação da visão lateral da malha utilizada no modelo axissimétrico.

Figura 5.7: Geometria do elemento térmico SOLID70 (Ansys15).

Figura 5.8: Propriedades térmicas do aço duplex SAF2205 (Xiaojun, 2004), onde a variável "K” representa a condutibilidade térmica e " $C_{p}$ ” 0 calor específico do material (adaptado).

Figura 5.9: Propriedades linearmente dependentes com a temperatura apresentadas por (XAVIER, 2013); a) calor específico e b) condutividade térmica (adaptado).

Figura 5.10: Propriedades físicas para o SAF2205 apresentadas por Daha (DAHA, 2012) (adaptado). 
Figura 5.11: Propriedades físicas termo dependentes apresentadas por (USHIO, 1997).

Figura 5.12: Variação das propriedades físicas, adotadas no presente trabalho, baseados nos dados apresentados por (XIAOJUN, 2004); evidenciando a) condutibilidade térmica, b) calor específico

Figura 6.1: Imagem evidenciando os termopares alocados na parte inferior do corpo de prova.

Figura 6.2: Vista inferior da chapa exibindo o esquema adotado para o posicionamento dos termopares utilizados nos corpos de prova com aportes térmicos menores.

Figura 6.3: Vista inferior da chapa exibindo o esquema adotado para o posicionamento dos termopares utilizados nos corpos de prova com aportes térmicos maiores.

Figura 6.4: Corpo de prova 2304P15,após realização do procedimento experimental de soldagem.

Figura 6.5: Corpo de prova 2205G25,após realização do procedimento experimental de soldagem.

Figura 6.6: Esquema da montagem do equipamento para os ensaios experimentais. (1- carro trator; 2- tocha de soldagem; 3- corpo de prova; 4- placa base; 5- termopares acoplados à chapa)

Figura 7.1: Ciclo térmico adquirido do processo experimental para a amostra 2205P15.

Figura 7.2: Ciclo térmico adquirido do processo experimental para a amostra 2205P25.

Figura 7.3: Ciclo térmico adquirido do processo experimental para a amostra 2304P15.

Figura 7.4: Ciclo térmico adquirido do processo experimental para a amostra 2304P25.

Figura 7.5: Ciclo térmico adquirido do processo experimental para a amostra 2205G15.

Figura 7.6: Ciclo térmico adquirido do processo experimental para a amostra 2205G25.

Figura 7.7: Ciclo térmico adquirido do processo experimental para a amostra 2304G15. 
Figura 7.8: Ciclo térmico adquirido do processo experimental para a amostra 2304G25.

Figura 7.9: Macrografia característica realizada em um dos corpos de prova (2205G15).

Figura 7.10: Macrografia característica realizada em um dos corpos de prova (2304G25).

Figura 7.11: Perfil de temperatura da amostra 2205P25, para as 3 condições de tamanho geométrico, no tempo de 108s.

Figura 7.12: Perfil de temperatura da amostra 2205P25, para as 3 condições de tamanho geométrico, no tempo de $448 \mathrm{~s}$.

Figura 7.13: Perfil de temperatura da amostra 2205P25, para as 3 condições de tamanho geométrico, no tempo final de aquisição dos dados, 638s.

Figura 7.14: Perfil de temperatura da amostra 2304P25, para as 3 condições de tamanho geométrico, no tempo final de aquisição dos dados, 108s.

Figura 7.15: Perfil de temperatura da amostra 2304P25, para as 3 condições de tamanho geométrico, no tempo final de aquisição dos dados, 448s.

Figura 7.16: Perfil de temperatura da amostra 2304P25, para as 3 condições de tamanho geométrico, no tempo final de aquisição dos dados, 638s.

Figura 7.17: Comparação entre o ciclo térmico adquirido do processo experimental e o numericamente simulado para a amostra 2205G15.

Figura 7.18: Imagem da ZF da amostra 2205G15.

Figura 7.19: Comparação entre o ciclo térmico adquirido do processo experimental e o numericamente simulado para a amostra 2304G15.

Figura 7.20: Imagem da ZF da amostra 2304G15.

Figura 7.21: Comparação entre o ciclo térmico adquirido do processo experimental e o numericamente simulado para a amostra 2205G25.

Figura 7.22: Imagem da ZF da amostra 2205G25.

Figura 7.23: Comparação entre o ciclo térmico adquirido do processo experimental e o numericamente simulado para a amostra 2304G25.

Figura 7.24: Imagem da ZF da amostra 2304G25. 
Figura 7.25: Comparação entre o ciclo térmico adquirido do processo experimental e o numericamente simulado para a amostra 2205P25.

Figura 7.26: Imagem da ZF da amostra 2205P25.

Figura 7.27: Comparação entre o ciclo térmico adquirido do processo experimental e o numericamente simulado para a amostra 2304P25.

Figura 7.28: Imagem da ZF da amostra 2304P25.

Figura 7.29: Macroscopia ilustrando a posição onde foram obtidos os ciclos térmicos simulados, a fim de serem comparados com a microestrutura encontrada experimentalmente.

Figura 7.30: Diagramas obtidos através do software "thermocalc" para os dois aços estudados no presente trabalho, indicando em função da temperatura as fases que estariam presentes em condições de equilíbrio (LUENGAS, 2017).

Figura 7.31: Ciclos térmicos simulados para a amostra 2205G25.

Figura 7.32: Imagens obtidas por microscopia da amostra 2205G25. Superior com um aumento de 100x, inferior com um aumento de 200x.

Figura 7.33: Ciclos térmicos simulados para a amostra 2304G25.

Figura 7.34: Imagens obtidas por microscopia da amostra 2304G25. Superior com um aumento de 100x, inferior com um aumento de 200x.

Figura 7.35: Ciclos térmicos simulados para a amostra 2205G15.

Figura 7.36: Ciclos térmicos simulados para a amostra 2205G15.

Figura 7.37: Imagens obtidas por microscopia da amostra 2205G15. Superior com um aumento de 100x, inferior com um aumento de 200x.

Figura 7.38: Ciclos térmicos simulados para a amostra 2304G15.

Figura 7.39: Imagens obtidas por microscopia da amostra 2304G15. Superior com um aumento de 100x, inferior com um aumento de 200x. 


\section{Lista de tabelas}

Tabela 3.1: Propriedades físicas de alguns aços inoxidáveis (SOLOMON e DEVINE, 1982).

Tabela 5.1: Geometrias utilizadas nos modelos numéricos.

Tabela 5.2: Propriedades termo físicas do aço SAF 2205 apresentadas por (ALMEIDA, 2016).

Tabela 6.1: Composição química nominal aço SAF 2205 e SAF 2304 (Sandvik, 2015).

Tabela 6.2: Composição química nominal do arame consumível 22.8.3.L G7.

Tabela 6.3: Parâmetros de soldagem utilizados nos experimentos.

Tabela 7.1: Profundidade medida da linha de fusão para cada amostra.

Tabela 7.2: Diferenças absolutas entre as temperaturas mínimas e máximas da amostra 2205P25, para os 3 tempos adotados, entre as geometrias 150x150mm e 150x300mm.

Tabela 7.3: Diferenças absolutas entre as temperaturas mínimas e máximas da amostra 2205P25, para os 3 tempos adotados, entre as geometrias 150x300mm e 150x600mm.

Tabela 7.4: Diferenças absolutas entre as temperaturas mínimas e máximas da amostra 2304P25, para os 3 tempos adotados, entre as geometrias 150x150mm e 150x300mm.

Tabela 7.5: Diferenças absolutas entre as temperaturas mínimas e máximas da amostra 2304P25, para os 3 tempos adotados, entre as geometrias 150x300mm e 150x600mm.

Tabela 7.6: Parâmetros do modelo da fonte de calor para as amostras com aporte térmico de $1,5 \mathrm{KJ} / \mathrm{mm}$.

Tabela 7.7: Diferenças absolutas entre as temperaturas de pico registradas no experimento e encontradas na simulação numérica para a amostra 2205G15.

Tabela 7.8: Diferenças absolutas entre as temperaturas de pico registradas no experimento e encontradas na simulação numérica para a amostra 2304G15. 
Tabela 7.9: Parâmetros do modelo da fonte de calor para as amostras com aporte térmico de $2,5 \mathrm{KJ} / \mathrm{mm}$.

Tabela 7.10: Diferenças absolutas entre as temperaturas de pico registradas no experimento e encontradas na simulação numérica para a amostra 2205G25.

Tabela 7.11: Diferenças absolutas entre as temperaturas de pico registradas no experimento e encontradas na simulação numérica para a amostra 2304G25.

Tabela 7.12: Diferenças absolutas entre as temperaturas de pico registradas no experimento e encontradas na simulação numérica para a amostra 2205P25.

Tabela 7.13: Diferenças absolutas entre as temperaturas de pico registradas no experimento e encontradas na simulação numérica para a amostra 2304P25.

Tabela 7.14: Temperaturas do balance de fases Austenita-Ferrita próximo 1:1 e temperatura de completa ferritização (LUENGAS, 2017). 
"Pessoas quietas têm as mentes mais barulhentas."

Stephen Hawking 


\section{1 \\ Introdução}

No início da década de 1930 emergiu uma nova classe de aços inoxidáveis que em meados dos anos 1940 adquiriu importância comercial. Esse aço é constituído por uma matriz bifásica, contendo um balanço entre suas fases austeno-ferrítica, sendo denominado por aço inoxidável duplex (AID). Ao passar dos anos e da modernização dos instrumentos tecnológicos de fabricação mecânica, essa classe de aço passou por inúmeras modificações e implementações.

Atualmente a indústria necessita cada vez mais de novos materiais capazes de operar em meios e com fluidos extremamente agressivos, para os quais ainda não se disponibiliza estudos e análises completas sobre seu comportamento ante esses meios. Os aços inoxidáveis duplex têm hoje em sua maioria aplicações que atendem a essas indústrias e exigências do mercado. Podem ser citadas indústrias no ramo de petróleo e gás, papel e celulose, plantas de dessalinização e químicas, que se enquadram nas exigência e demanda por materiais que exibam essas características (Practical Guidelines for the Fabrication of Duplex Stainless Steels, 2009).

Aços inoxidáveis duplex apresentam uma estrutura bifásica com frações proporcionais das fases, sendo este o grande distinguidor de suas vantagens. Suas propriedades melhores são obtidas quando se consegue atingir um balanço apropriado de percentagens de austenita e ferrita, juntamente com a abstenção de fases deletérias em sua microestrutura. Estes aços possuem elevados limites de resistência à tração e de escoamento, aliada a excelente resistência à corrosão por pites ou sob tensão em meios contendo cloretos. Destaca-se também a elevada tenacidade à fratura, desde que parâmetros como aporte térmico na soldagem, proteção da poça de fusão, temperatura e patamares de tratamento térmico quando aplicados sejam controlados (KOU, 2003; MESSLER, 1999; OLSSON, 1996).

Em detrimento da enorme aplicação dos aços duplex na indústria, falhas prematuras em equipamentos (LINTONA et al., 2004) vêm ocorrendo gerando lucros cessantes e perdas de produção, onde na sua grande maioria, estas falhas estão associadas à presença de trincas, corrosão e fraturas, em tubos de trocadores 
de calor. Estes materiais são utilizados em equipamentos e instalações cuja construção depende sempre da utilização de processos de soldagem (CHARLES, 2008). Esses processos empregados, envolvem a aplicação de uma fonte de calor localizada e intensa que promove elevados gradientes térmicos ao longo da peça.

O presente trabalho busca estabelecer uma metodologia para modelar o comportamento do processo de soldagem GMAW que seja adequado para descrever os ciclos térmicos sofridos em aços inoxidáveis duplex. O conhecimento desses ciclos térmicos permitirá uma previsão da microestrutura do material, principalmente na ZTA, uma vez conhecidas as cinéticas de precipitação nesses aços. 


\section{2}

\section{Objetivos}

O objetivo desse trabalho é desenvolver uma metodologia utilizando um modelo numérico computacional, parametrizado, baseado no método de elementos finitos, para reproduzir e obter ciclos térmicos do processo de soldagem GMAW nos aços duplex. O modelo desenvolvido considera apenas a análise térmica e a dependência das propriedades físicas com a temperatura.

Como objetivos específicos, pretende-se realizar soldas na forma de cordão sob chapa, em corpos de prova dos aços UNS S31803 e UNS S32304, compostos de duas geometrias e dois aportes térmicos, visando obter ciclos térmicos de soldagem. Objetiva-se então, com estes resultados, configurar e calibrar um modelo numérico parametrizado utilizando o método de elementos finitos, e validar o modelo. Em seguida, foram feitas análises acerca das propriedades termodependentes de cada material envolvido no estudo, bem como da influência das geometrias utilizadas nos resultados das simulações. Por fim, foram confrontados os dados dos ciclos térmicos simulados em diferentes pontos dos corpos de prova com as microestruturas obtidas de maneira experimental. 


\section{3}

\section{Revisão Bibliográfica}

\section{1}

\section{Breve História dos Aços Inoxidáveis Duplex}

Os primeiros aços inox foram desenvolvidos durante as primeiras décadas do século 20 na Alemanha e Grã-Bretanha e eram dos tipos martensíticos e ferríticos (Fe-Cr). Em seguida, as ligas formando os aços austeníticos Fe-Cr-Ni tornaram-se o maior grupo. Esta mudança ocorreu principalmente devido à maior facilidade de produção e soldagem deste tipo de aço.

Com o aprimoramento dos fornos e das técnicas de refino do material, foi possível alcançar teores mínimos de carbono, em torno de 0,08\%. Isso foi importante pelo fato de que níveis elevados de carbono ocasionam o fenômeno de sensitização nestes aços, que através da precipitação de carbonetos de cromo nos contornos de grão durante as execuções de soldagem e tratamentos térmicos, geram corrosão intergranular na zona termicamente afetada (ZTA).

Em 1927 ocorreu o primeiro relato sobre os aços duplex quando Bain e Griffiths publicaram no resultado de suas pesquisas a existência de um campo bifásico no sistema Fe-Cr-Ni composto de austenita e ferrita. Eles descreveram que eram ligas auteníticas-ferríticas com 22 a 30\% de Cr e 1,2 a 9,7\% de Ni. (OLSSON, 2009).

Em 1930 uma empresa sueca, Avesta Iron Works, desenvolveu dois aços duplex forjados aplicados na indústria de papel, o Grau 453E com liga de Cr-Ni, e o Grau 453 s com adição de molibdênio, cujo principal objetivo era reduzir o problema por corrosão intergranular que ocorria nos aços austeníticos. Apesar de estes aços possuírem o mesmo teor de carbono dos austeníticos, apresentaram claramente o aumento da resistência à corrosão intergranular e uniforme, conforme foi descrito por Payson e Harrison em 1932 e por Lindh em 1933.

Os primeiros aços duplex continham entre 60 e $70 \%$ de ferrita e como resultado, a liga apresentou uma microestrutura muito mais resistente do que os aços austeníticos. Em 1932 os aços duplex correspondiam a 6,5\% do total de aços 
inoxidáveis produzidos e com crescente demanda. Durante a Segunda Guerra Mundial a escassez de matérias-primas, especialmente o níquel, fez aumentar o interesse nos aços duplex. (OLSSON, 2009).

Existem relatos da produção de aços duplex na Finlândia por volta de 1930. Na França, a J. Holtzer Steel Works, garantiu a patente da liga duplex contendo $16-23 \%$ de $\mathrm{Cr}, 1,5-6,5 \%$ de $\mathrm{Ni}$, ate $3 \%$ de $\mathrm{Mo}$ e $\mathrm{W}$, e ate 2,5\% de $\mathrm{Cu}$. E foi a partir desta patente que a liga duplex URANUS 50 (UNS S32404) foi desenvolvida.

O aprimoramento das técnicas de refino em fornos por arco elétrico permitiu que fosse possível gradualmente reduzir os teores de carbono contido nos aços inoxidáveis austeníticos (AIA) e consequentemente nos duplex (AID) (OLSSON, 2009; PARDAL, 2009).

$\mathrm{Na}$ década de 40 foi observado que os aços inoxidáveis austeníticos apresentavam certa susceptibilidade à corrosão sob tensão (CST), e que poderia ser reduzida com a presença de ferrita, sendo mais uma aplicação dos AID. A alta resistência dos AID foi descrita por Colombier e Hochmann. A primeira liga duplex de baixo carbono e desenvolvida para resistir à corrosão sob tensão foi o 3RE60 (UNS S31500). Este grau de AID continha baixo cromo, porém mais molibdênio e silício que as primeiras ligas desenvolvidas. O 3RE60 (UNS S31500) foi usado em componentes onde a corrosão sob tensão era um problema nos aços inoxidáveis tipo 304 e 316.

Embora os primeiros aços inoxidáveis duplex demonstrassem ter uma melhor resistência à corrosão intergranular do que os aços inoxidáveis austeníticos, observou-se que nas soldagens a arco elétrico com baixa energia podiam ser geradas soldas com estrutura ferrítica contendo uma zona frágil localizada na ZTA. Isso foi atribuído em parte devido ao elevado nível de ferrita das primeiras series. Como a solubilidade do carbono na ferrita é baixa, o carboneto de cromo formado no contorno de grão poderia ocorrer mesmo em baixo teor de carbono $(<0,03 \% \mathrm{C})$, resultando em corrosão intergranular e redução da tenacidade da junta soldada (LIPPOLD, 2005; PARDAL, 2009).

Na década de 70 foi desenvolvido um aço inoxidável duplex com 22\% de cromo visando à solução dos problemas de suscetibilidade a corrosão intergranular na ZTA que, quando comparado aos antecessores, apresentava alto teor de molibdênio e a adição de nitrogênio. Esta nova patente indicava que a liga 
era resistente à corrosão intergranular após a soldagem, função da quantidade de cromo e com adição do nitrogênio, sendo a susceptibilidade do aço determinada pelo ensaio de Strauss ou Huey (GENTIL, 2003; GUNN, 2003; OLSSON, 1996).

Contudo, a faixa de composição química proposta, em particular o teor de nitrogênio adicionado, permitiu uma larga faixa com altos níveis de ferrita na zona termicamente afetada. Existiam padrões nacionais para o aço inoxidável duplex com 22\% Cr que especificavam a mesma faixa de nitrogênio. Desta forma, durante o processo de soldagem existe um alto risco de formação de zonas termicamente afetadas totalmente ferríticas ou com altos teores da mesma. Ligas puderam ser produzidas, com precipitação de carbonetos e nitretosintergranular e intragranular, dentro da referida especificação. Isto poderia causar fragilização pelo hidrogênio e corrosão por pites.

A adoção de faixas de composição mais rigorosas, em especial de nitrogênio, indicou ser a melhor solução. Produtos mais modernos contendo 0,150,20\% N e 22\% Cr apresentaram maior resistência mecânica, melhor resistência à corrosão do que os inoxidáveis austeníticos 316L e 317L em algumas aplicações, sendo superiores ao N08904 (904L). Esta nova liga duplex foi designada por 32205 (OLSSON, 1996).

Na década de 80 foi descrito pela primeira vez o papel do nitrogênio no controle dos ciclos térmicos de soldagem. Programas com bases de dados termodinâmicos foram utilizados para determinar o desenvolvimento de fases durante tratamentos térmicos e ciclos de soldagem proporcionando aos fornecedores a selecionar uma composição balanceada nos metais base, metais de solda e zona termicamente afetada. O nitrogênio também foi fundamental para o controle da cinética das transformações de fase e no aumento na resistência a corrosão por pites, de maneira similar aos aços inoxidáveis austeníticos (IMOA, 2009; LIPPOLD, 2005; McGUIRE, 2008; MESSER, 2007; PARDAL, 2009; SANDVIK, 2009).

Ainda na década de 80, no desenvolvimento dos aços inoxidáveis superduplex (AISD), informações termodinâmicas também foram utilizadas. Nos AISD UNS32750, o balanço e a composição da austenita e ferrita foram otimizadas resultando uma alta liga com elevada resistência à corrosão por pites e resistência mecânica quando comparada as ligas duplex com 22\% Cr. Assim, os aços inoxidáveis superduplex se tornaram uma alternativa competitiva em relação 
aos aços inoxidáveis super austeníticos com 6\%Mo para serviço em ambientes agressivos da indústria offshore, tais como: equipamentos com alta pressão de trabalho e sistemas com água do mar.

Outros resultados dos desenvolvimentos na década de 80 foram alguns aços inoxidáveis duplex de baixa liga, como exemplo o S32304 que, quando comparado aos AIA 304L e 316L, possuem maiores resistência a corrosão e resistência mecânica, gerando ganhos na redução de espessura de equipamentos.

\section{2}

\section{Características dos aços inoxidáveis duplex}

Os aços inoxidáveis duplex surgiram na década de 1930, porém este material somente começou a ser utilizado no Brasil a partir da década de 1990 (MARTINS E CASTELETTI, 2007).

Os aços inoxidáveis duplex são materiais que apresentam microestrutura bifásica, de tal forma que se obtém uma estrutura composta por uma matriz ferrítica e ilhas de austenita, com frações volumétricas aproximadamente iguais dessas duas fases. Proporção alcançada principalmente pelo balanceamento dos elementos de liga, estabilizadores da austenita (carbono, níquel, nitrogênio, cobre e manganês) e estabilizadores de ferrita (cromo, molibdênio, tungstênio, nióbio e silício) (PADILHA, 2009).

Essa classe de materiais é caracterizada por apresentar combinação de elevadas propriedades mecânicas e de resistência à corrosão em meios agressivos devido à sua habilidade em se passivar e permanecer no estado passivo em diversos meios aos quais é submetido (SENATORE, 2007). Essa propriedade está relacionada, principalmente, aos elementos de liga presentes na composição química do aço, embora outros fatores como tamanho de grão, distribuição e morfologia de inclusões, fases precipitadas e qualidade da superfície também exerçam influencia (SENATORE, 2007; PARDAL, 2011; SOUZA, 2015).Em razão do efeito do refino de grão, obtido pela estrutura austenítica-ferrítica e ao endurecimento por solução sólida, os aços inoxidáveis duplex apresentam resistência mecânica superior aos aços inoxidáveis austeníticos e ferríticos. Eles possuem baixo coeficiente de expansão térmica, alta condutividade térmica e são ferromagnéticos devido à presença de ferrita. (CHAWLA, 1995). 
Apresentam de maneira geral em sua composição, cerca de 20 a 30\% de cromo, 5 a 10\% de níquel e 1,5 a 5\% de molibdênio; incluindo cobre, tungstênio e nitrogênio, assim como um baixo teor de carbono (SOLOMON,1982). O molibdênio, juntamente com o cromo, é forte estabilizador da ferrita e auxilia na melhoria da resistência à corrosão uniforme e localizada. O nitrogênio favorece e acelera a formação da austenita e a endurece fortemente.

Os aços inoxidáveis duplex apresentam boa tenacidade e ductilidade quando a quantidade de ferrita e austenita é balanceada, aliado a maior resistência à corrosão sob tensão quando comparados aos aços inoxidáveis austeníticos (a austenita contribui com a tenacidade ao impacto e a ferrita, mais dura, melhora as características de resistência mecânicas) (BONAVINA, 2003).

\subsection{1}

\section{Microestrutura}

A microestrutura duplex é obtida através do balanceamento dos elementos de liga e de tratamento termomecânico durante a conformação mecânica a aproximadamente $1200^{\circ} \mathrm{C}$ (BRANDI, 2008). Na faixa de temperatura de $1200^{\circ} \mathrm{C}$, os aços inoxidáveis apresentam um comportamento muito próximo do equilíbrio estável e metaestável, produzindo uma estrutura lamelar com grãos alongados na direção de laminação e composta por uma matriz ferrítica com ilhas de austenita, figura 3.1, sendo de aproximadamente 35-55 \% de ferrita e 45-65 \% de austenita. (SOLOMON, 1982).

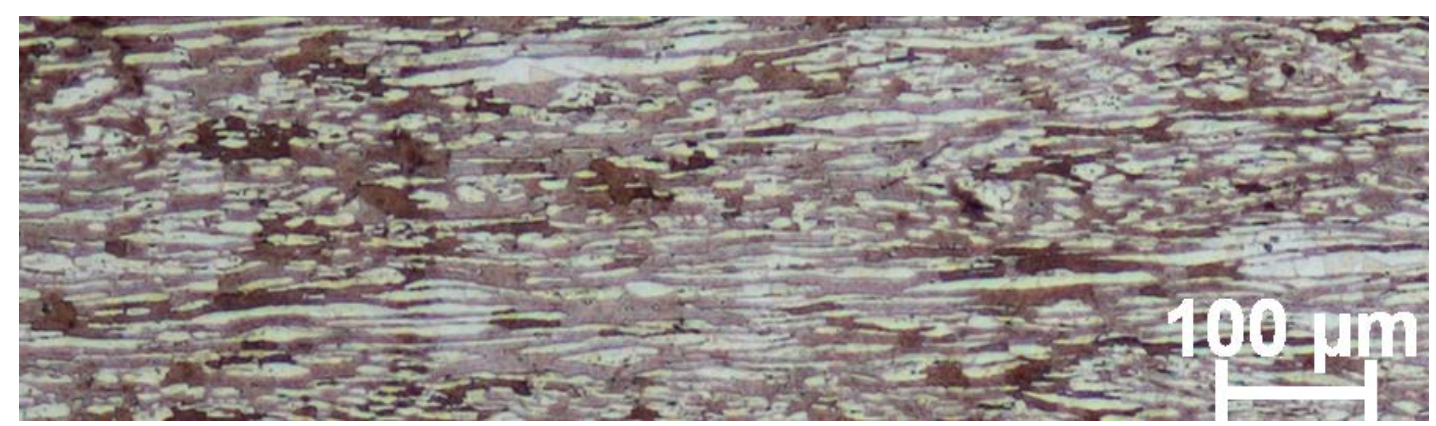

Figura 3.1: Microestrutura típica do aço inoxidável duplex, mostrando a estrutura lamelar com matriz ferrítica com ilhas de austenita.

O balanceamento dos elementos de liga, nos aços inoxidáveis, tem a função de controlar os teores de elementos estabilizadores de austenita, ou 
gamagênicos (níquel, carbono, nitrogênio) e de elementos estabilizadores da ferrita, ou alfagênicos (cromo, molibdênio e silício). Com isso, o conceito de cromo e níquel equivalentes é determinado em função da composição química dos aços inoxidáveis, considerando os elementos estabilizadores das fases ferrita e austenita (SOLOMON, 1982).

Assim, em uma análise referente ao sistema ternário Fe-Cr-Ni, quatro fases sólidas são encontradas, a saber: austenita $(\gamma)$, de estrutura CFC; ferrita $(\alpha)$, de estrutura CCC e ferrita ( $\left.\alpha^{\prime}\right)$, com estrutura também CCC, porém esta se apresenta rica em cromo, e todas as três são soluções sólidas. A quarta fase sólida encontrada é um intermetálico denominado sigma $(\sigma)$, de estrutura tetragonal, onde além de ser frágil e consideravelmente duro, é não magnético (RAYNOR, 1988).

Para a formação da microestrutura característica da liga, analisando a seção isotérmica para o sistema ternário Fe-Cr-Ni, mostrada abaixo (Fig. 3.2), observa-se um campo bifásico (ferrita + austenita), desde que a composição correta seja alcançada, assim como a execução do tratamento de solubilização seguido de um resfriamento rápido.

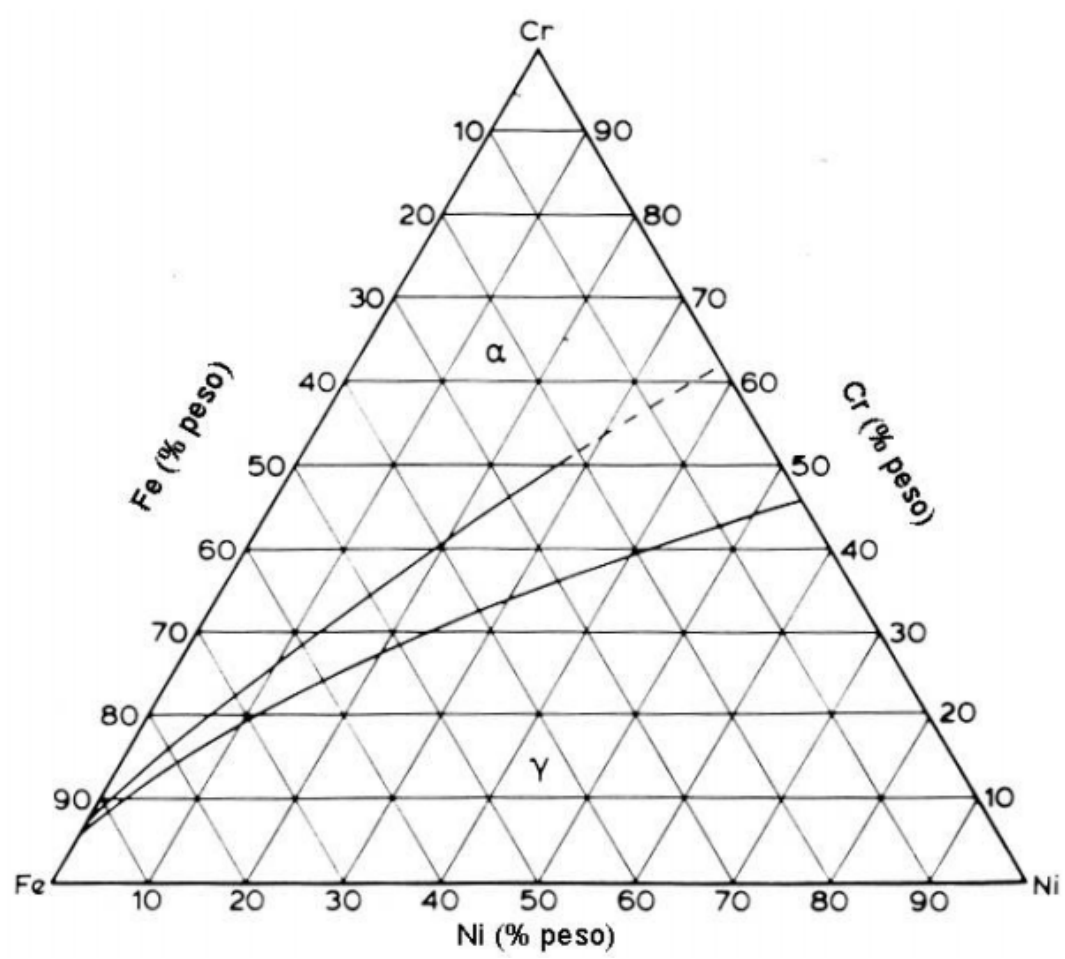

Figura 3.2: Seção isotérmica do sistema ternário Fe-Cr-Ni a $1300^{\circ} \mathrm{C}$ (RAYNOR, 1988). 
Ponderando sobre as seções isotérmicas para o mesmo sistema, agora com o decréscimo regular da temperatura em questão (Fig. 3.3 - Fig. 3.5), é observado o contínuo aumento da área relacionada ao campo bifásico em cada seção.

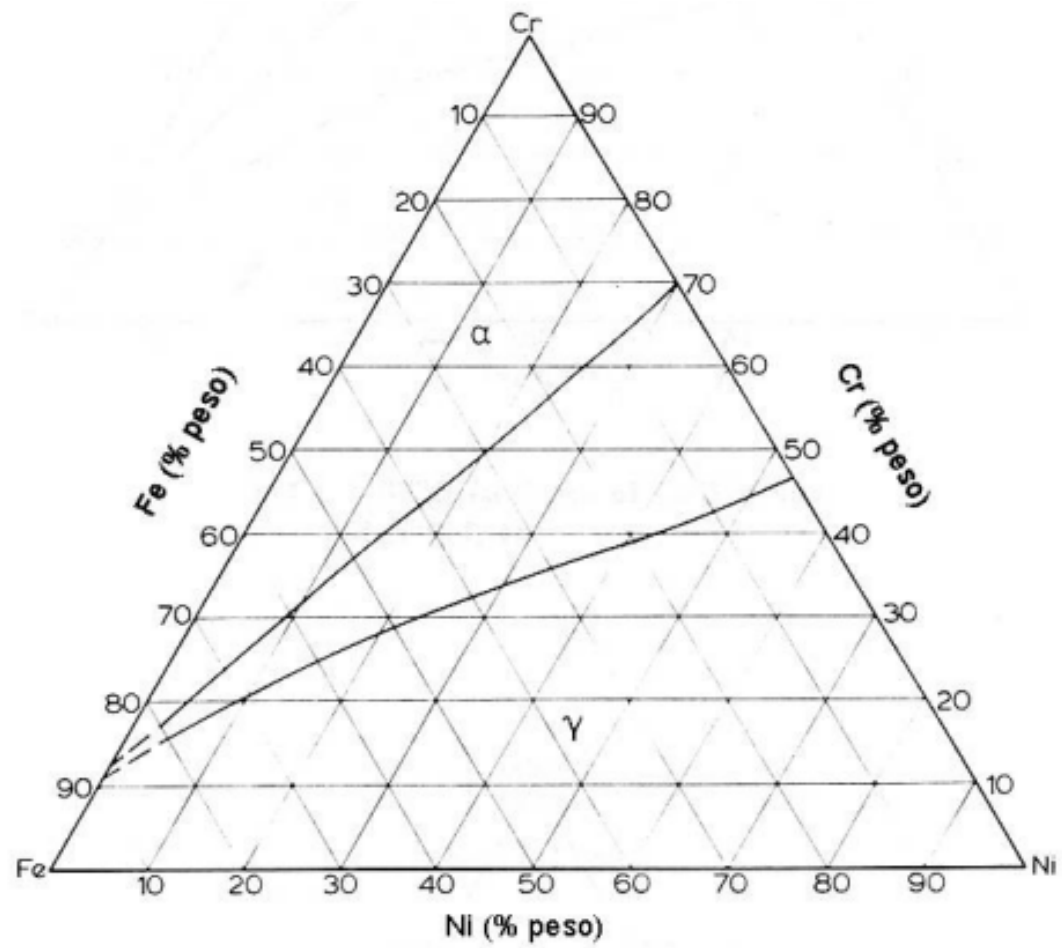

Figura 3.3: Seção isotérmica do sistema ternário Fe-Cr-Ni a $1200^{\circ} \mathrm{C}$ (RAYNOR, 1988).

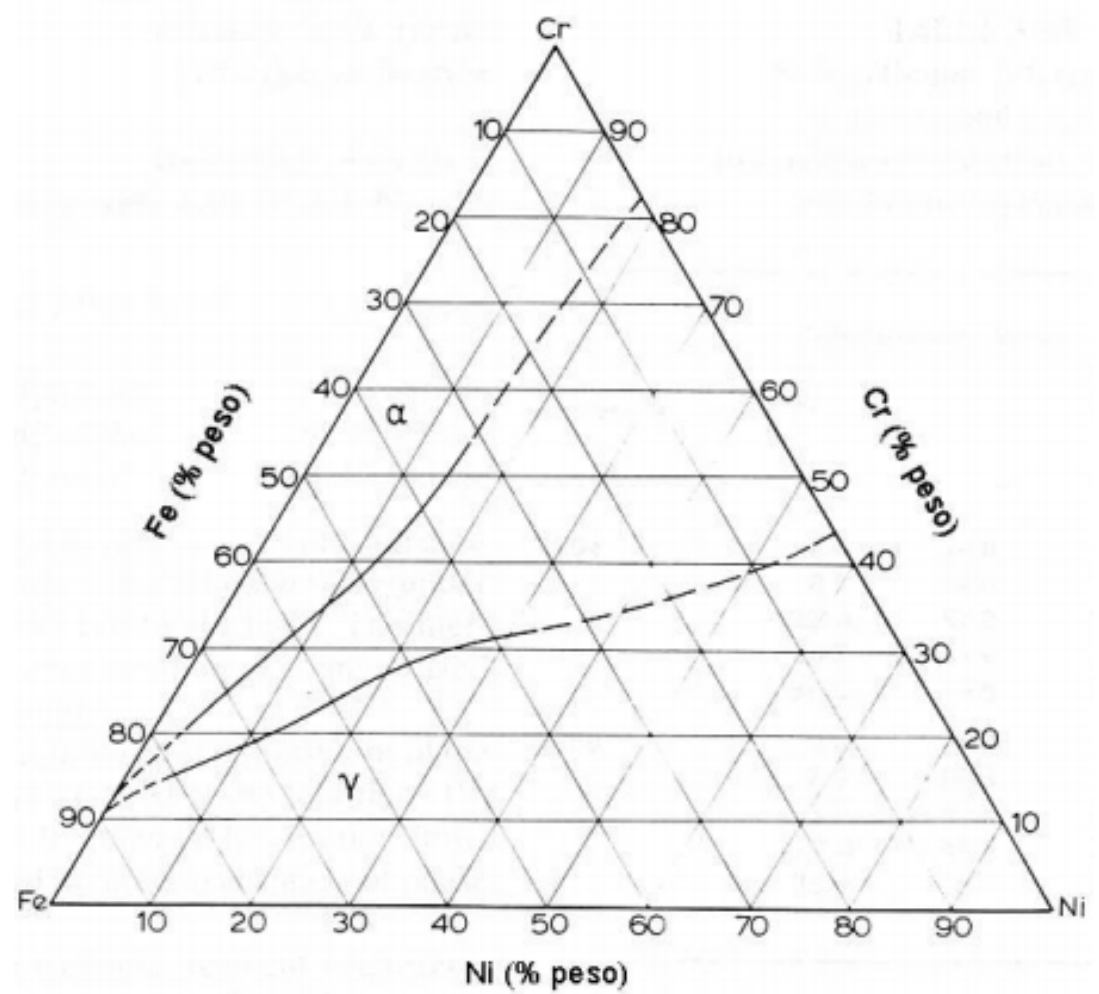

Figura 3.4: Seção isotérmica do sistema ternário Fe-Cr-Ni a $1100^{\circ} \mathrm{C}$ (RAYNOR, 1988). 


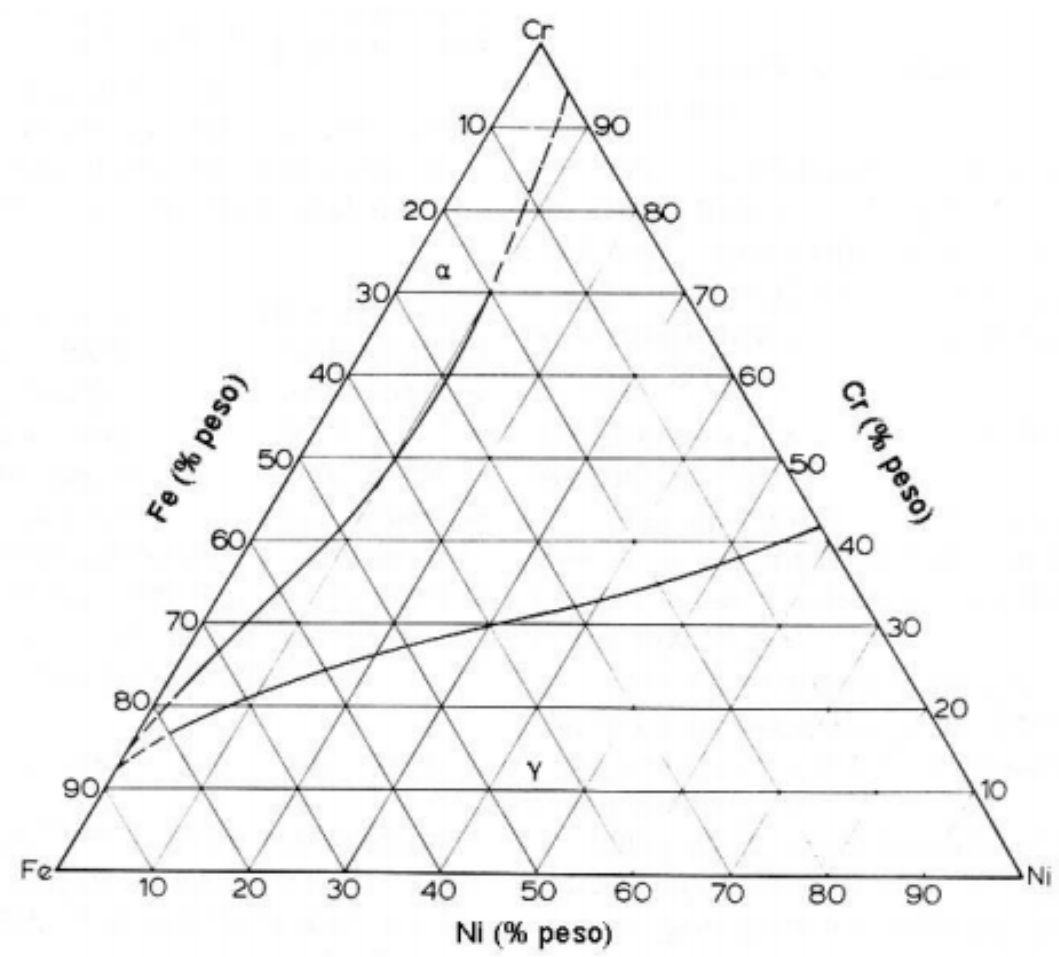

Figura 3.5: Seção isotérmica do sistema ternário Fe-Cr-Ni a $1000^{\circ} \mathrm{C}$ (RAYNOR, 1988).

De maneira equivalente, o equilíbrio das fases austenita e ferrita nos aços inoxidáveis duplex pode ser observado utilizando um diagrama de fases pseudobinário (70\% Fe em massa), como mostrado na Fig. 3.6. Convém ressaltar que este diagrama não considera todos os outros elementos presentes nos aços duplex, como é o caso por exemplo do nitrogênio, que possui caráter fortemente gamagênico mesmo em pequenos teores (BORSATO, 2001). O diagrama mostra de maneira esquemática a solidificação do aço inoxidável duplex, onde acontece uma transformação no estado sólido de parte da ferrita em austenita. Assim, caso as condições de resfriamento sejam favoráveis e impeçam a formação de outras fases, na temperatura ambiente existirá apenas uma microestrutura bifásica austenita + ferrita. 


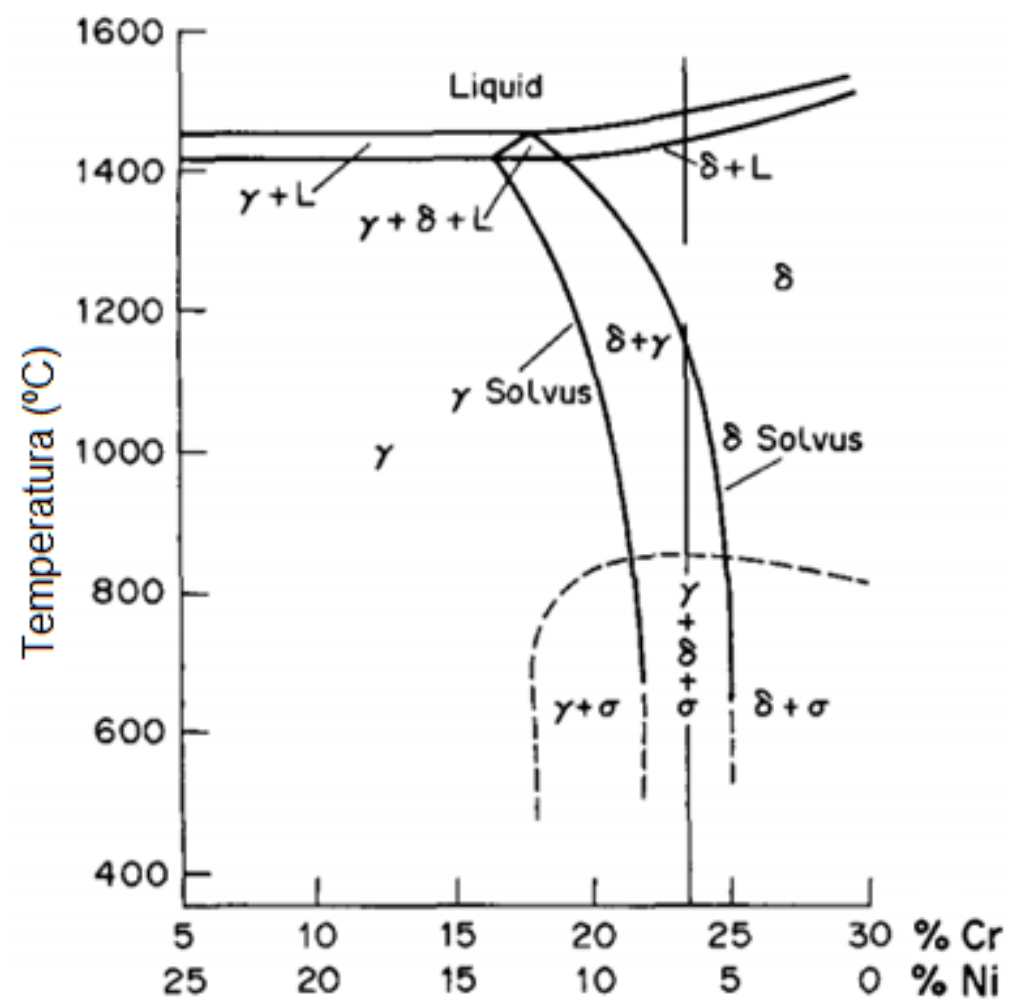

Figura 3.6: Diagrama pseudo-binário $(70 \% \mathrm{Fe}$ em peso) do sistema $\mathrm{Fe}-\mathrm{Cr}-\mathrm{Ni}$ (ATAMERT*, 1991).

\section{2 .2}

\section{Propriedades Físicas}

Os diferentes tipos de aços inoxidáveis duplex são classificados em três grupos, com relação à composição química e suas aplicabilidades:

Aços inoxidáveis duplex de baixa liga ou Leanduplex: devido ao menor teor de elementos de liga são materiais econômicos, não possuem molibdênio na composição química e podem substituir aços inoxidáveis austeníticos como AISI 304L/316L (o aço inoxidável duplex UNS S32304 é o mais indicado).

Aços inoxidáveis duplex de média liga: nessa família, enquadram-se os aços inoxidáveis duplex mais utilizados. O aço inoxidável duplex UNS S31803 é o mais indicado. Apresentam resistência à corrosão intermediária entre os austeníticos comuns AISI 304L/316L e aços inoxidáveis super austeníticos com 5 e $6 \%$ de molibdênio.

Aços inoxidáveis duplex de alta liga: comumente designados por super duplex. O UNS S32750 apresenta elevada resistência à corrosão comparável aos super austeníticos que possuem entre 5 e 6 \% de molibdênio. 
A condutibilidade térmica dos aços inoxidáveis duplex é maior do que a dos aços inoxidáveis austeníticos. Devido à presença da fase ferrita, os aços inoxidáveis duplex possuem menor coeficiente de expansão térmica que os austeníticos (próximo a dos ferríticos), fazendo com que estas ligas apresentem comportamento próximo ao dos aços carbono, (SENATORE, 2007) o que os tornam aconselháveis para uso em condições de ciclos térmicos, em temperaturas de aplicação menores do que $300^{\circ} \mathrm{C}$. Essas duas propriedades atuando conjuntamente, acabam por tornar os aços inoxidáveis duplex bons candidatos à utilização em trocadores de calor. São também fortemente magnéticos devido à presença de ferrita, permitindo o uso de fixadores magnéticos durante o processo de usinagem e inspeção.

Na Tabela 3.1 apresentam-se as propriedades físicas de alguns aços inoxidáveis, sendo ressaltado o S31803.

Tabela 3.1: Propriedades físicas de alguns aços inoxidáveis (SOLOMON e DEVINE, 1982).

\begin{tabular}{|c|c|c|c|c|c|c|c|}
\hline \multirow{2}{*}{ Tipo } & \multirow{2}{*}{$\begin{array}{l}\text { Grau } \\
\text { UNS }\end{array}$} & \multirow{2}{*}{$\begin{array}{l}\text { Temp } \\
{\left[{ }^{\circ} \mathrm{C}\right]}\end{array}$} & \multirow{2}{*}{$\begin{array}{l}\text { Módulo } \\
\text { Young } \\
\text { [GPa] }\end{array}$} & \multirow{2}{*}{$\begin{array}{l}\text { Calor } \\
\text { Específico } \\
{[\mathbf{J} / \mathbf{k g . K}]}\end{array}$} & \multirow{2}{*}{$\begin{array}{l}\text { Condutividade } \\
\text { Térmica } \\
{[\mathbf{W} / \mathbf{m} . \mathbf{K}]}\end{array}$} & \multicolumn{2}{|c|}{$\begin{array}{l}\text { Coeficiente de Expansão } \\
\text { Térmica Linear }\end{array}$} \\
\hline & & & & & & $\begin{array}{l}\text { Temp } \\
{\left[{ }^{\circ} \mathrm{C}\right]}\end{array}$ & $10^{-6} / \mathrm{K}$ \\
\hline \multirow{2}{*}{ Ferrítico } & S 43000 & 20 & 205 & 480 & 22 & $20-100$ & 10 \\
\hline & S 44700 & 20 & 205 & 480 & 21 & $20-100$ & 10 \\
\hline \multirow{2}{*}{ Austenítico } & S 30400 & 20 & 205 & 520 & 16 & $20-100$ & 16 \\
\hline & S 08904 & 20 & 205 & 544 & 15 & $20-100$ & 16 \\
\hline \multirow{4}{*}{ Duplex } & \multirow{4}{*}{ S 31803} & 20 & 200 & 450 & 17 & \multirow{2}{*}{$20-100$} & \multirow{2}{*}{13,5} \\
\hline & & 100 & 190 & 450 & 18 & & \\
\hline & & 200 & 180 & 500 & 19 & $20-200$ & 14 \\
\hline & & 300 & 170 & 550 & 20 & $20-300$ & 14,5 \\
\hline \multirow{8}{*}{ Superduplex } & \multirow{3}{*}{ S 32550} & 20 & 200 & 450 & 17 & $20-200$ & 13,5 \\
\hline & & 100 & 190 & 450 & 18 & $20-300$ & 14 \\
\hline & & 200 & 180 & 530 & 19 & $20-500$ & 14,5 \\
\hline & \multirow{5}{*}{ S 32750} & 20 & 200 & 470 & 16 & \multirow{2}{*}{$20-100$} & \multirow{2}{*}{13} \\
\hline & & 100 & 190 & - & 17 & & \\
\hline & & 200 & 180 & - & 19 & $20-200$ & 13,5 \\
\hline & & 300 & 170 & - & 20 & $20-300$ & 14 \\
\hline & & 400 & 160 & - & 21 & $20-400$ & 14,5 \\
\hline
\end{tabular}




\subsection{3}

\section{Propriedades Mecânicas}

As propriedades mecânicas de um aço inoxidável duplex refletem as propriedades mecânicas das fases individuais austenita e ferrita, particularmente a fase ferrita. A ferrita, quando adicionada à austenita, tem o papel de aumentar o limite de escoamento de um aço duplex, especialmente em baixas temperaturas (SOLOMON e DEVINE, 1982).

Quanto às propriedades mecânicas, os aços inoxidáveis duplex ocupam um lugar de destaque na indústria, pois possuem um limite de resistência mínimo à tração superior de $700 \mathrm{MPa}$, limite de escoamento mínimo superior a $450 \mathrm{MPa}$ e alongamento em $50 \mathrm{~mm}$ de $25 \%$. A alta tenacidade dessa liga é o resultado do pequeno tamanho de grão associado a forte presença de austenita em sua estrutura (BORSATO, 2006).

A combinação entre os elevados valores de alongamento da austenita com o elevado limite de escoamento da ferrita nos aços inoxidáveis duplex, formam um conjunto de notáveis propriedades mecânicas. Os aços inoxidáveis duplex apresentam elevado limite de escoamento, na ordem de duas vezes o valor dos aços austeníticos. Além disso, apresentam um alongamento mínimo em torno de 25\%. O comportamento mecânico dos aços inoxidáveis duplex está intimamente relacionado com a característica de cada fase, por isso o balanceamento entre as frações volumétricas de austenita e ferrita deve estar próximo de 50\% para cada uma das fases, a fim de se maximizar as propriedades mecânicas. (SENATORE, 2007).

Os aços inoxidáveis duplex apresentam alta resistência ao impacto na temperatura ambiente $\left(25^{\circ} \mathrm{C}\right)$. Sua tenacidade está limitada à fração volumétrica e distribuição da ferrita. Com uma fração volumétrica de austenita da ordem de $40 \%$, obtém-se prevenção efetiva do crescimento de trincas. Dessa forma, a orientação e a morfologia da estrutura dos aços duplex são importantes na avaliação da tenacidade. Vários documentos apresentaram as ligações entre propriedades mecânicas e microestrutura, isso inclui o efeito de tratamento térmico, precipitação de fases e as propriedades mecânicas do material (NILSSON, 1997; DAKHLAOUI, 2007). 
Para os aços inoxidáveis duplex UNS S31803 e UNS S32750, o percentual da fase sigma em torno de 1 a $2 \%$, já reduz de forma drástica a tenacidade dos aços, mesmo se as propriedades de tração forem menos afetadas. A transformação mais comum é a decomposição espinoidal da ferrita em $\alpha^{\prime}$ - separação da ferrita em teores baixo e alto de cromo em uma escala muito pequena. Esta transformação é conhecida como a transformação de $475^{\circ} \mathrm{C}$ (acontece principalmente entre 280 e $475^{\circ} \mathrm{C}$ ). Observa-se também um endurecimento subsequente e fragilização da ferrita. Isto explica por que a maioria das aplicações é restrita a temperaturas mais baixas que $250^{\circ} \mathrm{C}$ (CHARLES, 2008).

A resistência à corrosão é determinada pela capacidade de passivação dos aços inoxidáveis duplex e de permanecer nesse estado no ambiente a que estiver exposto. Essa propriedade está relacionada, principalmente, aos elementos de liga presentes na composição química do aço, embora outros fatores como tamanho de grão, distribuição e morfologia de inclusões, precipitação de fases e qualidade da superfície também exerçam influência.

\section{3}

\section{Soldagem dos Aços Inoxidáveis Duplex}

A soldabilidade dos aços inoxidáveis duplex é semelhante à dos aços austeníticos, porém, cuidados especiais são necessários com alguns tipos de fragilizações por precipitação por exemplo, que podem ocorrer diante do processo. Estas precipitações estão diretamente relacionadas à história térmica do material soldado, ou à energia de soldagem utilizada no processo.

A energia de soldagem está rigorosamente associada às transformações microestruturais e ao desempenho da junta soldada. Assim, uma energia de soldagem elevada provoca uma baixa velocidade de resfriamento, favorecendo a precipitação de austenita e o equilíbrio microestrutural do aço inoxidável duplex. Entretanto, uma baixa energia de soldagem, resulta numa elevada velocidade de resfriamento, retardando a precipitação de austenita e a formação equilibrada das fases (FEDELE, 1999; BRANDI, 1999).

Os aços inoxidáveis duplex podem ser soldados por praticamente todos os processos de soldagem a arco convencionais (CUNHA, 1996; BRANDI, 1996; STILL, 1994). No entanto processos que fazem uso de uma fonte de calor de alta 
densidade, como laser ou feixe de elétrons, tem sua aplicação limitada devido ao impedimento na formação da austenita uma vez que a junta sofre elevadas velocidades de resfriamento (VAROL*, 1992). Soldagem por explosão e por eletroescória tem sido utilizadas para fazer revestimentos com aços inoxidáveis duplex (NOBLE, 1996; OLSSON, 1986). O aporte térmico e a espessura do material são parâmetros importantes a ter em conta durante a seleção adequada do processo de soldagem dependendo da sua aplicação final (TAVARES et al., 2007)

Além da busca de uma energia de soldagem ótima, deve-se ainda considerar o fato de que, na soldagem multipasses, a junta é submetida a vários ciclos térmicos. Isto significa que a região soldada passa por aquecimentos e resfriamentos consecutivos, geralmente pouco controlados. Tais variações de temperatura podem modificar a microestrutura original e, por consequência, comprometer o desempenho da junta.

Os consumíveis de soldagem para aços inoxidáveis duplex atualmente utilizados podem ser classificados de dois tipos, ligados ao níquel e de mesma composição do metal-base.

A utilização dos consumíveis ligados ao níquel, mantém o balanço de fases e controle microestrutural da zona fundida. Porém, a falta de nitrogênio e a presença frequente de nióbio nestas ligas contribuem para a ocorrência de reações metalúrgicas desfavoráveis como a formação de precipitados e regiões com elevado teor de ferrita, como na ZTA (CUNHA, 1996; BRANDI, 1996).

Em teoria, a aplicação de um tratamento térmico após a soldagem na faixa de $1050^{\circ} \mathrm{C}$ visa balancear a microestrutura, fornecendo a energia e tempo necessários para a precipitação da quantidade ideal de austenita do aço duplex. Consumíveis, àqueles de mesma composição do metal base, porém enriquecido em níquel melhoram o balanço de fases na condição de como soldado, aumentando a quantidade de austenita no metal de solda. Desse modo, as soldas realizadas com estes consumíveis não necessitam de tratamento térmico após a soldagem (FEDELE, 1999).

As mesmas práticas aplicadas para a soldagem de aços inoxidáveis austeníticos como por exemplo limpeza da junta, evitar a contaminação da poça de fusão por aço carbono, uso de gás de purga no passe de raiz, entre outros devem também ser utilizadas nos aços inoxidáveis duplex. Todo o procedimento de soldagem deve ser determinado com o objetivo de garantir que a junta soldada 
continue sendo aço inoxidável duplex, com sua microestrutura balanceada e livre de precipitados (VASCONCELLOS, 2008).

Portanto o controle do aporte de calor, a escolha do metal de adição, o tipo de chanfro, a aplicação ou não de preaquecimento e tratamento térmico póssoldagem, assim como o controle da temperatura interpasse e velocidade de resfriamento são todos parâmetros que podem criar a possibilidade de crescimento exagerado de grão na zona afetada pelo calor, e o risco de precipitação de fases fragilizantes. Deve- se buscar parâmetros que permitam obter uma junta soldada que mantenha as propriedades mecânicas e de resistência a corrosão da liga original as menos alteradas possíveis.

\section{4}

\section{Ciclo Térmico}

O decurso da fonte térmica durante a operação de soldagem, provoca variações de temperatura em diversos pontos situados próximos à junta soldada. Os ciclos térmicos sofridos em cada ponto do material soldado determinam as transformações microestruturais, e, portanto, as propriedades esperadas para uma junta (ZEEMANN, 2001). Considerando um ponto qualquer de uma junta soldada, onde sua posição espacial é definida pela distância ao centro da solda e pela sua posição relativa à espessura do material, a variação da temperatura em função do tempo $\left(\mathrm{T}_{(\mathrm{t})}\right)$ é o ciclo térmico no ponto considerado, de acordo com a figura 3.7 a seguir: 


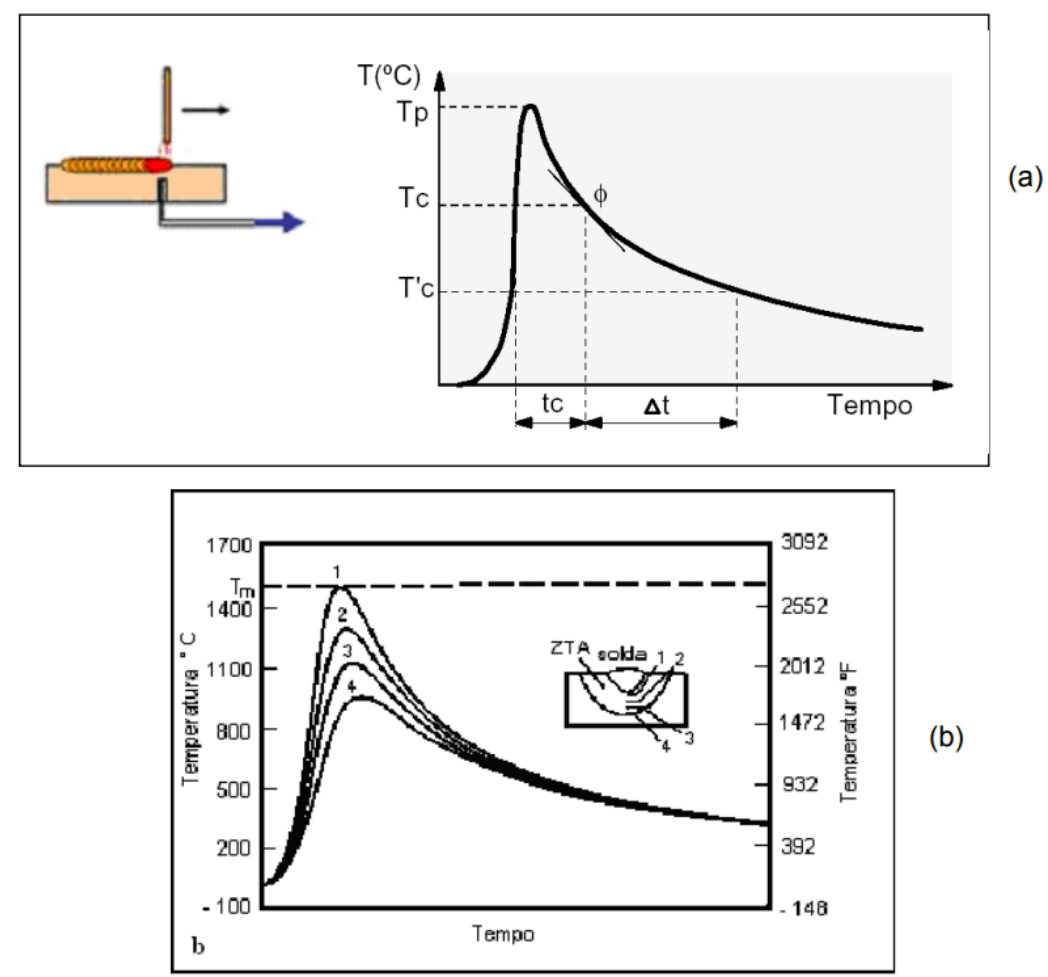

Figura 3.7: (a) Curva esquemática de um ciclo térmico; (b) Variações de temperatura ao longo de uma junta (ZEEMANN, 2001).

Esquematicamente exibidas curvas de ciclo térmico para um cordão de solda na figura 3.7(a), a saber:

$\mathrm{T}_{\mathrm{p}}=>$ Temperatura máxima atingida no ponto;

$\mathrm{T}_{\mathrm{C}}=>$ Temperatura crítica;

$t_{c}=>$ Tempo de permanência acima da temperatura crítica;

$\phi=>$ Velocidade de resfriamento.

A figura 3.7(b) mostra o afastamento linear de pontos com relação ao centro da solda, e a consequente queda na temperatura máxima em cada um dos pontos adotados. Também se nota uma defasagem nas temperaturas máximas em cada ponto, devido ao fluxo de calor na amostra, assim como o tempo de permanência acima de uma temperatura estabelecida decresce no mesmo sentido. Hipoteticamente as velocidades de resfriamento decrescem à medida que a distância do ponto aumenta, em relação ao centro da solda. Todavia, de um ponto de vista prático, e para a faixa de temperatura onde ocorrem os fenômenos de transformações microestruturais mais relevantes, pode-se considerar a velocidade 
de resfriamento como sendo constante em toda extensão da zona termicamente afetada (ZTA). A maneira como o calor é dissipado do material influencia diretamente o ciclo térmico quanto ao resfriamento e a própria velocidade de resfriamento, que é obtida pela derivada da curva na região de interesse (MARQUES, 2007; MODENESI, 2000). Essa velocidade de resfriamento assume valores mais elevados quando a peça a ser soldada apresenta dimensões que proporcionem uma dissipação de calor no regime tridimensional (ZEEMANN, 2001).

Com relação à temperatura de pico atingida em uma região, esta determina a extensão da ZTA durante a soldagem e traz grandes influencias sobre as transformações microestruturais ocorridas. Assim a temperatura de pico atingida em um determinado ponto, a velocidade de resfriamento e o tempo de permanência acima de uma temperatura crítica previamente estabelecida, são características importantes do ciclo térmico de soldagem (MARQUES, 2007).

\section{5}

\section{Partição Térmica}

A partição térmica é uma função obtida a partir da análise de todos os pontos obtidos através do ciclo térmico, mostrando assim a variação da temperatura de pico com a distância ao centro do cordão de solda na direção perpendicular a este, de acordo com a figura 3.8 a seguir.

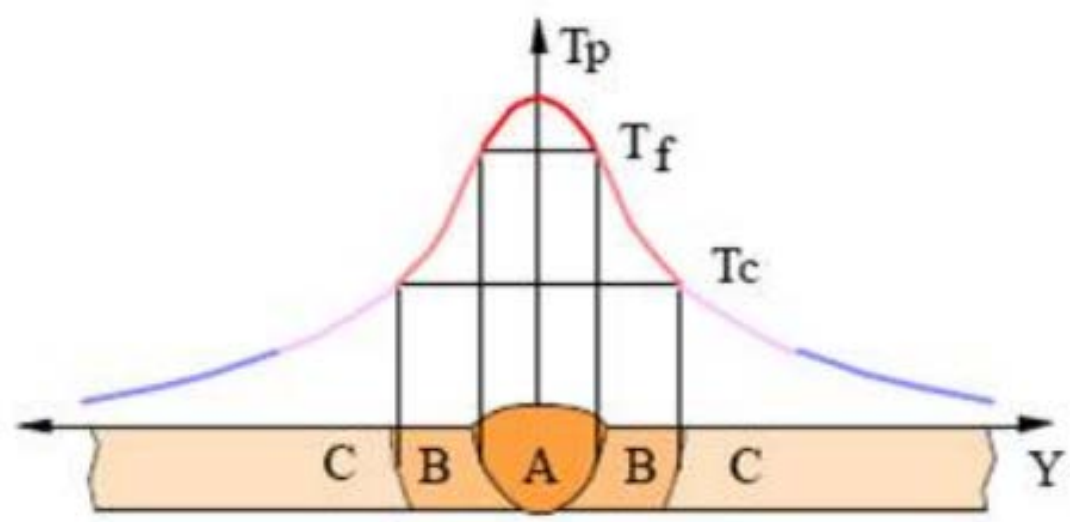

Figura 3.8: Desenho mostrando a repartição térmica para um determinado cordão de solda, evidenciando três regiões da solda. Região A - Zona Fundida (ZF); Região B Zona Termicamente Afetada (ZTA); Região C - Metal de Base (MB) (MARQUES, 2007). 
Com a obtenção dos ciclos térmicos e da partição térmica, torna-se viável o estudo das transformações metalúrgicas, que ocorrem no estado sólido, em uma junta soldada. O ciclo térmico possibilita assim a previsão das transformações, enquanto a partição térmica permite determinar a possível extensão das zonas onde se passam tais fenômenos (CUNHA, 1989).

\section{6}

\section{Metalurgia da soldagem dos aços inoxidáveis duplex}

A soldagem envolve muitos fenômenos como fusão, solidificação, transformações microestruturais, tensões causadas pela distribuição de calor e tensões de contração que causam inúmeros problemas práticos.

Na soldagem dessas ligas, a microestrutura varia desde a poça de fusão até o metal adjacente à solda como consequência da história térmica (ciclos térmicos e repartição térmica) experimentada. Assim, a microestrutura final depende da velocidade de resfriamento a partir de cada temperatura máxima presente na repartição térmica.

\subsection{1}

\section{Influência dos Elementos de Liga na Microestrutura da Junta Soldada}

Em geral, a velocidade de decomposição da austenita durante a soldagem é afetada pela presença de determinados elementos de liga, favorecendo ou suprimindo a ocorrência desta transformação, em função da velocidade de resfriamento. Portanto a taxa de resfriamento determina as transformações de fase que ocorrem na ZTA.

O Cromo é um elemento essencial para a formação da camada de óxido de cromo (como já citado anteriormente), ou camada passivadora, sendo assim o principal responsável pela resistência à corrosão dos aços inoxidáveis (SCHWEITZER, 1996). Outros elementos podem influenciar a efetividade do cromo na formação ou manutenção do filme, mas nenhum outro elemento pode, por si só, criar as propriedades dos aços inoxidáveis. Quando em teores menores do que 10,5\%, o efeito favorável do cromo na resistência à corrosão existe, mas é 
muito fraco (FIG. 3.9), assim valores maiores são necessários para se garantir uma razoável resistência à corrosão atmosférica (MODENESI, 2001). A fim de aumentar a estabilidade do filme passivo, necessário em ambientes mais agressivos, maiores teores de cromo são necessários. Os altos teores de cromo necessários ao aumento da resistência à corrosão podem afetar as propriedades mecânicas do material, quando utilizado em ambientes que exigem altas temperaturas assim como a soldabilidade, sendo o principal elemento que estabiliza a ferrita.

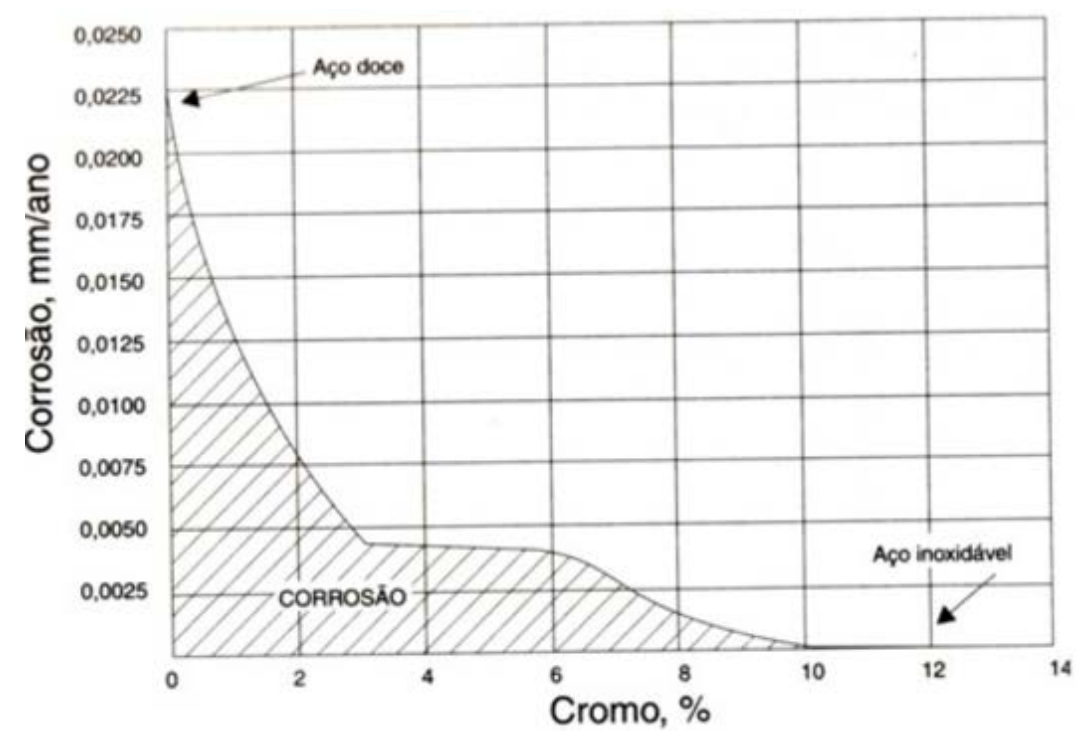

Figura 3.9: Influência do teor de cromo na taxa de corrosão de uma liga $\mathrm{Fe}-\mathrm{Cr}$ (MODENESI, 2001).

Assim como o Cromo, o Molibdênio tende a estabilizar a ferrita e aumentar a temperabilidade da liga, e estabiliza o filme de óxido de cromo, aumentando a passividade, melhorando assim a resistência à corrosão da liga (FOLKHARD, 1988). Atua na diminuição da autodifusão através da distorção na rede contribuindo assim para o aumento de resistência mecânica.

Uma das consequências da utilização do Níquel na liga é a estabilização da estrutura austenítica, quando utilizado em quantidades suficientes (ASM HANDBOOK, 2002; EGHLIMI, 2013). Acelerando a cinética de precipitação da fase ferrita embora a fração volumétrica desta fase seja, em geral, reduzida (HUANG, 2005).

De forma análoga ao Níquel, o Manganês também estabiliza a estrutura austenítica, favorecendo sua formação, quando em quantidades moderadas. 
Apesar de existir uma limitação quanto ao seu uso, significando que não pode haver uma total substituição do níquel por manganês na liga, pois altos teores desse elemento, quando interagem com enxofre, podem formar sulfetos que são susceptíveis à corrosão seletiva. (SMITH, 1981).

Nitrogênio: É um elemento austenitizante, com a função de estabilizar a fase austenita em altas temperaturas. A adição deste elemento se refere à problemas primeiramente encontrados no momento da soldagem dos aços inoxidáveis duplex, onde ferrita era formada em larga escala na região soldada, diminuindo assim a resistência à corrosão e a dureza do material. Assim, a fim de prevenir esses problemas, era necessário recompor uma fração de austenita através de tratamentos térmicos, o que tornava a utilização da liga muito mais custosa (SEDRIKS, 1996).

A solubilidade do carbono e do nitrogênio em aços inox duplex é limitada e se torna ainda mais reduzida a baixas temperaturas. Ambos os elementos preferem se concentrar na austenita, devido a um maior número de sítios tetraédricos a solubilidade de elementos intersticiais é mais elevada nesta fase. A ferrita dissolve pequenas quantidades de carbono e nitrogênio em sítios octaédricos e, por esse motivo a formação de carbonetos e nitretos ocorrem exclusivamente na fase ferrítica e nos contornos de grão entre as fases ferrítica e austenítica. A figura 3.10 mostra um diagrama temperatura-tempo-precipitação (Diagrama TTP) para o aço duplex UNS S31803 indicando as fases intermetálicas que podem precipitar (SEDRIKS, 1996; RAMIREZ, 2003). 
Figura 3.10: Curvas TTP para a precipitação de fases intermetálicas em um AID UNS S31803 solubilizado a $1050^{\circ} \mathrm{C}$ por $30 \mathrm{~min}$ (SEDRIKS, 1996).

Como mostra a figura 3.10, a precipitação dos AID’s pode ser dividida, basicamente em dois grupos (LONDONO, 1997; LIPPOLD, 2005):

- Fragilização de baixa temperatura $\left(\sim 475^{\circ} \mathrm{C}\right)$ : ocorre numa faixa de temperatura de 400 a $500^{\circ} \mathrm{C}$. Este tipo de fragilização limita a temperatura máxima de aplicação em serviço dos aços inoxidáveis duplex;

- Fragilização de alta temperatura: ocorre na faixa de temperatura de 600 a $1000^{\circ} \mathrm{C}$, onde precipitam diversas fases intermetálicas. Comumente, quando da realização de soldagem, os aços duplex ficam expostos a ciclos térmicos compreendidos por esta faixa, o que justifica maior crédito a este grupo.

As fases secundárias de maior importância, formada durante a fabricação e soldagem dos duplex, são todas formadas acima de $500^{\circ} \mathrm{C}$, a citar: sigma- $\sigma$, chi- $\chi$, austenita secundária $\left(\gamma_{2}\right)$, carbonetos e nitretos, todos. As reações de precipitação abaixo de uma temperatura limite operacional $\left(400-500^{\circ} \mathrm{C}\right)$ são relativamente lentas e de menor preocupação com a fragilização (TOPOLSKA, 2009). Observase que não só a resistência à corrosão é influenciada pela formação dessas fases intermetálicas, mas também é notada perda de propriedades mecânicas, sendo a dureza uma das propriedades mais afetadas (NOBLE, 1996).

Em um processo de soldagem ou em solicitações com temperaturas elevadas, as fases secundárias podem aparecer como precipitações (FONSECA et al, 2017; MAGNABOSCO, 2009). Estes compostos podem ser prejudiciais para 
as propriedades do aço, principalmente na zona termicamente afetada, dependendo das distribuições de frações de tamanho e volume. O precipitado principal que aparece neste caso é a fase sigma, embora outros precipitados, como a fase chi ou os nitritos, possam ser encontrados. Sabe-se que a fase chi pode ser um precursor da fase sigma, que também é prejudicial para as propriedades do aço inoxidável duplex (FONSECA et al, 2017; MAGNABOSCO, 2009).

A literatura sobre a caracterização das fases chi e sigma é amplamente discutida e indicou que essas fases deletérias podem ser formadas em grande quantidade se a temperatura for mantida em torno de $800^{\circ} \mathrm{C}$ por tempos superiores a 30 minutos (FONSECA et al, 2017; MAGNABOSCO, 2009). Este não é um intervalo de tempo típico na zona crítica para a maioria dos processos comuns de soldagem de juntas pequenas. No entanto, para equipamentos e peças de soldagem de maiores tamanhos, é comum usar o procedimento de soldagem com múltiplos passes e algumas regiões podem recair sobre o intervalo de temperatura e tempo “adequado” para formar as fases deletérias (CASTRO et al, 2017). Assim, o projeto de um processo de soldagem adequado é importante para fazer ou reparar o equipamento em questão, a fim de trabalhar em condições de segurança (XAVIER et al, 2016).

\section{7 \\ Características e microestrutura dos AID durante o processo de soldagem}

Durante a soldagem de um AID por qualquer processo de soldagem que envolva fusão, haverá a formação de um ciclo térmico que promoverá mudanças microestruturais na zona termicamente afetada (ZTA). Estas mudanças devem ser controladas de modo que as propriedades da junta soldada sejam as melhores possíveis e este controle pode ser dado através da composição química e da história térmica. A composição química do metal de solda (MS) pode ser controlada através do metal de adição e/ou da composição do gás de proteção. A história térmica determinará a microestrutura na ZTA dos AIDs. 


\subsection{1}

\section{Influência das taxas de resfriamento sobre as transformações nos aços inox duplex}

O ciclo térmico é controlado pela energia de soldagem. Uma alta energia de soldagem resulta em baixa taxa de resfriamento, facilitando a transformação da ferrita em austenita. Por outro lado, tal condição tende a produzir depósitos com grãos mais grosseiros, uma ZTA mais extensa, e possivelmente a precipitação de fases intermetálicas. Assim, os parâmetros de soldagem devem ser controlados para garantir que as condições gerais de resfriamento permitam obter uma reforma adequada da austenita evitando, ao mesmo tempo, precipitações deletérias na ZTA (GUNN, 1997). Com esta finalidade, algumas diretrizes sugeriram faixas de aportes térmicos para soldagem de aços inoxidáveis duplex. Na prática, foram recomendados tempos de resfriamento entre 800 e $500{ }^{\circ} \mathrm{C}\left(\Delta \mathrm{t}_{8 / 5}\right)$, situados na faixa de 8-30 s, correspondendo aproximadamente a 4-15 s para o tempo de resfriamento entre 1200 e $800{ }^{\circ} \mathrm{C}\left(\Delta \mathrm{t}_{12 / 8}\right)$, que é mais relevante para aços duplex, pois recai sobre este intervalo a reforma da austenita (NASSAU, 1983; LILJAS, 1994). Este tempo de resfriamento é normalmente alcançado, dependendo da espessura do metal de base e geometria da junta, com energia de soldagem entre 0,5 e $2,5 \mathrm{KJ} / \mathrm{mm}$.

Além disso, algumas fases, incluindo austenita secundária $\left(\gamma_{2}\right)$, nitretos de cromo e carbonetos, também são propensas a serem formadas durante a soldagem dos aços duplex, fato que pode afetar suas propriedades como resistência à corrosão e propriedades mecânicas (CHEN, 2002; NOWACKI, 2006; TOPOLSKA, 2009). A austenita secundária pode formar-se nos aços duplex como resultado de ciclos de reaquecimento, tais como no processo de soldagem multipasse, tendo como resultado crítico principal a perda de resistência à corrosão da soldagem. De acordo com o ciclo térmico da soldagem, a austenita secundária pode ser formada durante o resfriamento como resultado das transformações $\alpha+\gamma \rightarrow \alpha+\gamma+\gamma_{2}$ na estrutura austeno-ferrítica. Também pode diretamente nuclear e crescer a partir da ferrita pela transformação difusional ( $\alpha$ $\rightarrow \gamma_{2}$ ) ou pode se formar como resultado da decomposição eutetóide da ferrita ( $\alpha$ $\left.\rightarrow \sigma+\gamma_{2}\right)$ (NOWACKI, 2005; NOWACKI, 2006). 
Menores aportes térmicos implicam em maiores taxas de resfriamento, favorecendo a formação de nitretos de cromo nas soldas dos aços duplex, fato que aumenta a sua susceptibilidade à corrosão por pites. Uma maior quantidade de ferrita estará presente nas soldas dos aços duplex, com taxas de resfriamento crescentes, devido ao menor tempo disponível para que a transformação difusional de ferrita em austenita possa ocorrer. Levando-se isto em consideração e o fato da ferrita possuir menor solubilidade do nitrogênio do que a austenita, pode ser atribuído à ferrita um papel importante no processo de precipitação de nitretos de cromo nos aços duplex (CHEN, 2002; MUTHUPANDI, 2003).

Assim, para evitar a precipitação de nitretos de cromo em soldas de aços duplex, recomenda-se o uso de altos aportes térmicos (dentro dos limites 0,5 - 2,5 $\mathrm{KJ} / \mathrm{mm}$ ) durante o processo de soldagem, uma vez que taxas de resfriamento mais lentas favorecem a reforma da austenita, além de promover a difusão de elementos estabilizadores da austenita, como o níquel e o nitrogênio (CHEN, 2002; YANG, 2011).

Apesar de um papel menor desempenhado pelos carbonetos nos aços duplex modernos devido ao seu conteúdo de carbono muito baixo, alguns carbonetos típicos como $\mathrm{M}_{23} \mathrm{C}_{6}$ podem ocorrer em soldas de aços duplex e até mesmo no metal base, causando os mesmos efeitos deletérios que os precipitados da fase sigma (BADJI, 2008). A precipitação de carbonetos de cromo $\mathrm{Cr}_{23} \mathrm{C}_{6}$ ocorre primeiro nas interfaces ferrita/austenita e cresce nos grãos de ferrita (BADJI, 2008), embora alguns trabalhos tenham relatado pouca ou nenhuma ocorrência de carbonetos em soldas ou após tratamentos térmicos dos aços duplex (LIOU, 2002; CALLIARI, 2006).

A figura (FIG. 3.11) indica as transformações microestruturais que podem ocorrer em uma junta soldada, de um AID, devido ao ciclo térmico de soldagem. São apresentadas cinco regiões distintas, o metal de solda (MS), zona parcialmente fundida a qual corresponde a diluição e é a zona de ligação, zona de crescimento de grão ferrítico ou zona de grãos grosseiros, zona bifásica parcialmente transformada e zona bifásica semelhante ao metal de base. Neste diagrama são apresentadas apenas as fases ferrítica e austenítica. 


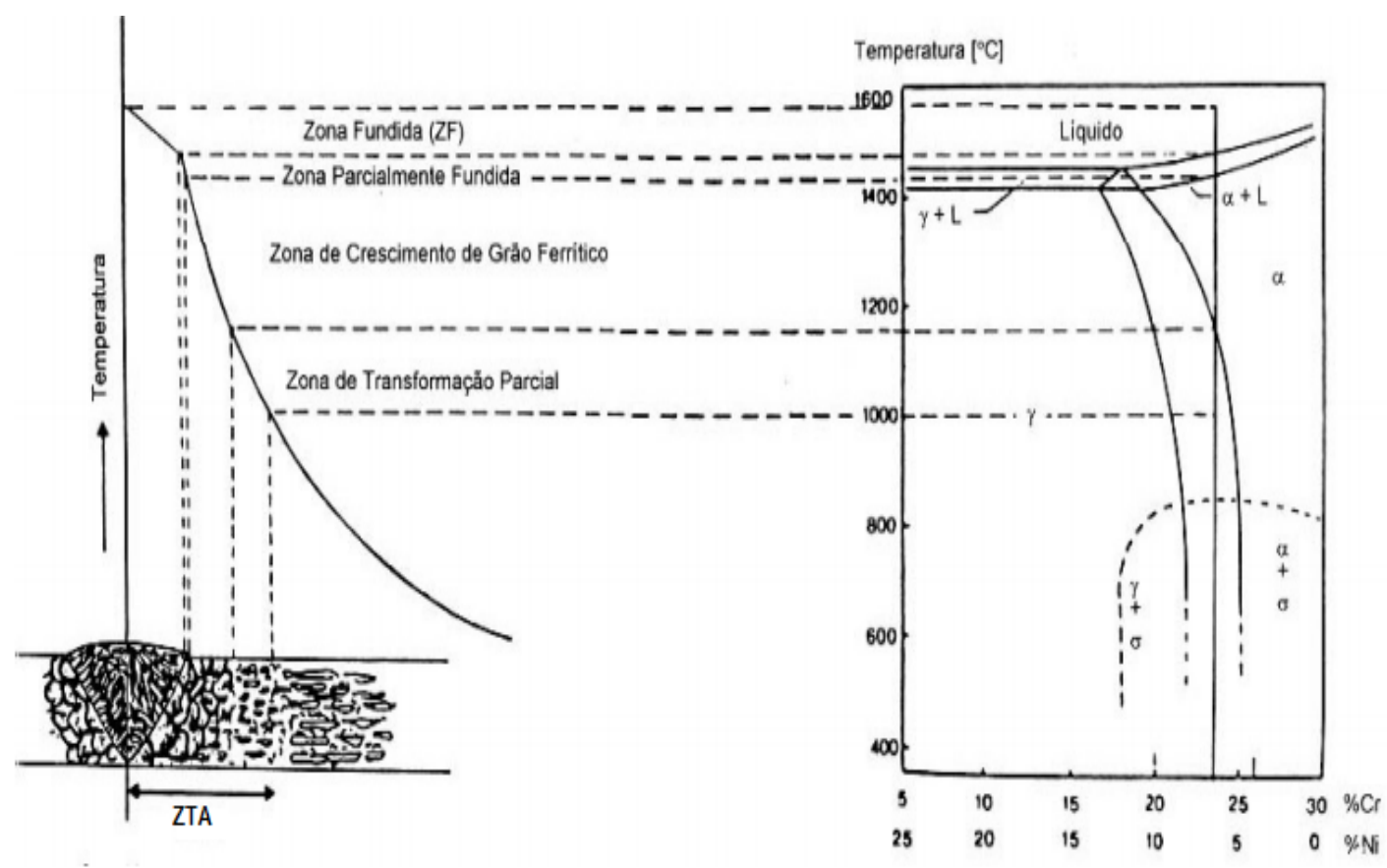

Figura 3.11: Diagrama esquemático exibindo as mudanças na estrutura de uma junta soldada de um AID submetido a um processo de soldagem (ATAMERT, 1992).

\section{7 .2}

\section{Zona Termicamente Afetada (ZTA)}

Os ciclos térmicos dos processos de soldagem estão diretamente relacionados às temperaturas de pico e as taxas de resfriamento. A partição térmica determina a extensão da ZTA, figura 3.12, assim como as temperaturas máximas nas diferentes regiões que a compõe.

Uma vez que, por definição, ZTA é a região compreendida entre o metal de solda (ou zona fundida) e o metal de base não afetado pelo calor inserido através do ciclo térmico de soldagem, esta pode ser dividida, de maneira geral, em duas sub-regiões (ATAMERT, 1992; LILJAS, 1996), a saber: uma região é submetida à temperaturas elevadas (ZTATE), sendo esta região delimitada pelas temperaturas solvus da ferrita e a temperatura solidus da liga, onde o aço duplex se encontra completamente ferritizado. E a outra região está associada a temperaturas baixas (ZTATB), apresentando como limite superior a temperatura solvus da ferrita. Nesta região da ZTA o campo do AID continua bifásico, porém com diferentes frações volumétricas finais de austenita. 


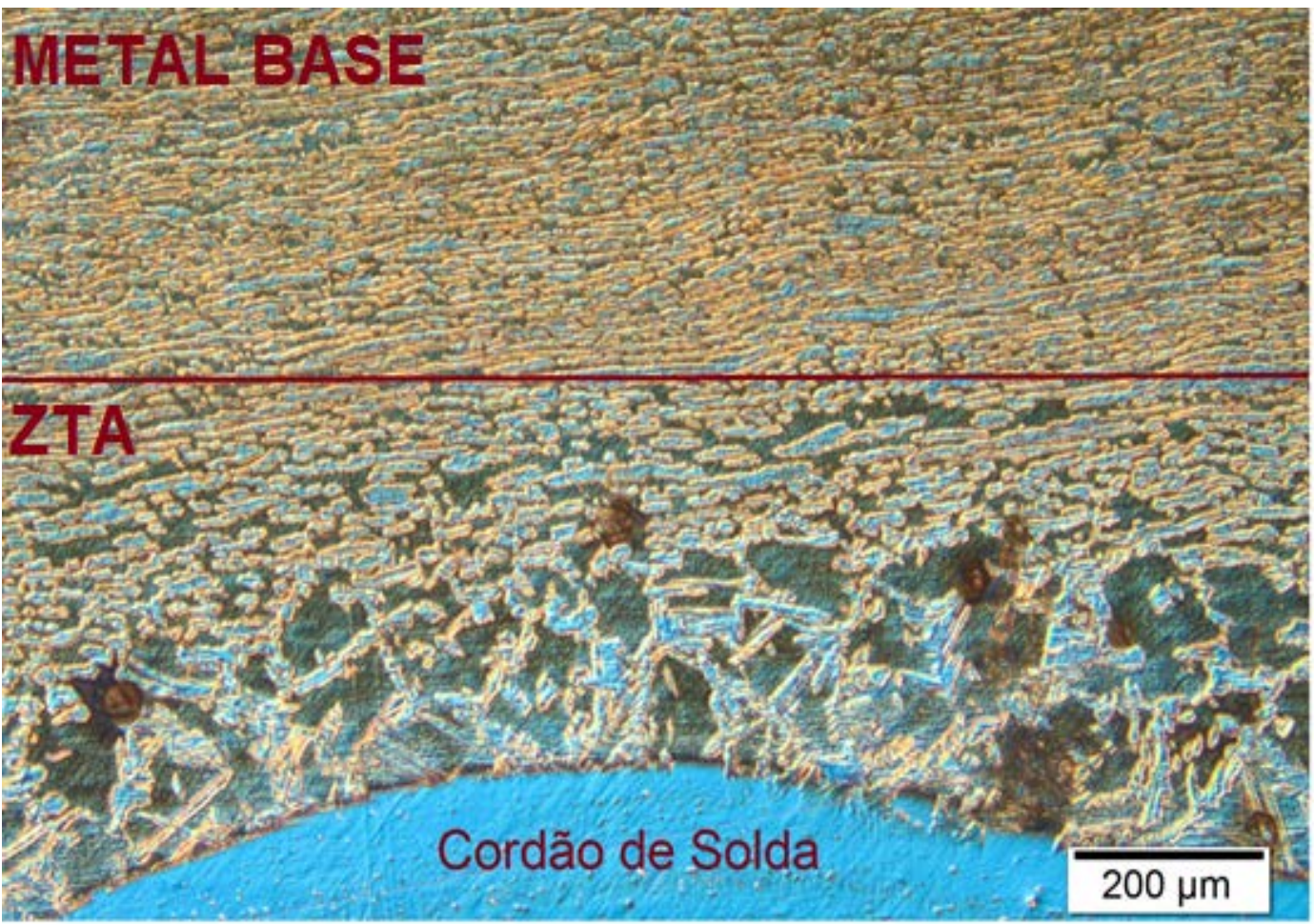

Figura 3.12: Imagem de um aço inoxidável duplex, destacando a região que foi afetada pelo calor de um processo de soldagem.

\subsubsection{1}

\section{Zona Termicamente Afetada de Temperatura Elevada (ZTATE)}

Uma característica fundamental dessa região é a largura (ou extensão) da ZTATE, a qual é determinada pela geometria da junta, parâmetros de soldagem e composição química do aço. A ZTA é definida com relação ao campo monofásico do diagrama de fases do aço em questão.

Tanto a dissolução parcial da austenita e dos precipitados durante o aquecimento estão envolvidos nas transformações no estado sólido, quanto a reformação de austenita e precipitados durante o resfriamento em contorno de grão ferrítico e em alguns sítios intragranulares. As transformações na ZTA podem ser explicadas conforme apresentado na figura abaixo FIG. 3.13, que representa um AID que se torna completamente ferrítico em temperaturas elevadas, como o 2205 (com baixo nitrogênio: 0,1\% N) e o 2304. 


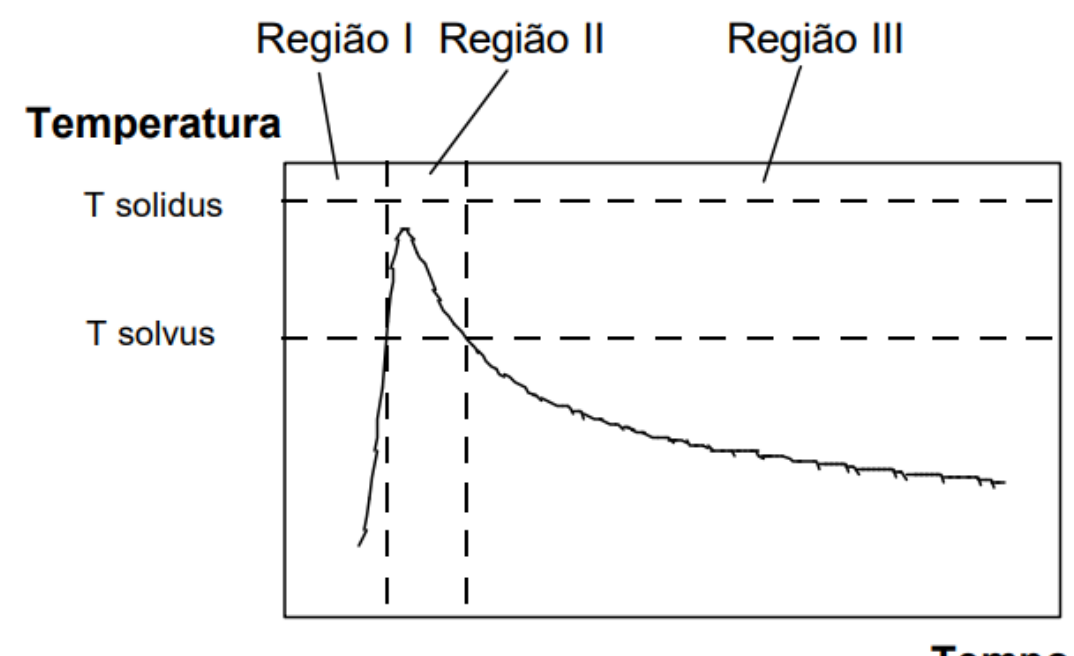

Figura 3.13: Regiões de um ciclo térmico de soldagem da ZTATE (VAROL, 1992).

\section{$\underline{\text { Região I - região de aquecimento: }}$}

$\mathrm{Na}$ região I, o metal base é aquecido a temperaturas próximas a temperatura solvus da ferrita. Nessa faixa de temperatura, a difusão de elementos intersticiais e substitucionais transformam austenita em ferrita, até que toda estrutura fique eventualmente ferritizada. A taxa de aquecimento irá determinar a cinética da dissolução da austenita. Se for muito elevada impedirá a dissolução da mesma, até mesmo em temperaturas acima da solvus da ferrita (VAROL, 1992). Precipitados como nitretos, carbonetos ou intermetálicos também podem sofrer dissolução durante o aquecimento, dependendo da taxa a que são submetidos.

$\underline{\text { Região II - região de altas temperaturas: }}$

Na região II, a temperatura elevada, acima da temperatura solvus da ferrita, acelera a cinética de dissolução dos precipitados e da austenita. Quando a velocidade do aquecimento não é muito elevada essas transformações tendem a se completar, resultando apenas em ferrita, e a partir deste momento os grãos começam a crescer e coalescer, uma vez que não existe segunda fase nem precipitados para inibir o crescimento. O tempo e a temperatura a que o material é exposto acima da temperatura solvus, enquanto a microestrutura é completamente ferrítica, irá determinar o tamanho dos grãos. Quanto mais baixa for a temperatura solvus da ferrita, mais nítido será o crescimento do grão de ferrita. A temperatura Solvus é altamente dependente da composição química da liga. O tamanho do grão pode impactar o material de diversas maneiras, através de 
suas propriedades mecânicas, como por exemplo diminuir sua ductilidade. Alguns modelos foram propostos para dimensionar o tamanho do grão na ZTA a partir do tempo de permanência acima da temperatura solvus ou do $\Delta t_{12-8}$ (ATAMERT, 1992; VAROL, 1992; LINDBLOM, 1991; KIVINEA, 1994).

A temperatura solvus da ferrita varia de aproximadamente 1250 a $1350^{\circ} \mathrm{C}$ para a família dos aços inoxidáveis duplex, dependendo da composição da liga, assim como a largura da região completamente ferrítica (região II) na ZTA pode variar significativamente. Ligas como a 2205 (com baixo teor de N) e a 2304 tendem a ter a temperatura solvus da ferrita mais baixas e próximas para essas duas ligas, enquanto que ligas superduplex por exemplo, tendem a ter a temperatura solvus da ferrita próximas ou até acima de $1350^{\circ} \mathrm{C}$.

\section{$\underline{\text { Região III - região de resfriamento: }}$}

Na região III, abaixo da temperatura solvus da ferrita, o resfriamento promove a precipitação da austenita, a partir da ferrita. A transformação de ferrita para austenita para uma determinada liga é controlada pela taxa de resfriamento, onde uma alta taxa de resfriamento atrasará essa transformação e assim uma ZTA com maior porcentagem de ferrita irá ocorrer. Essa transformação nos contornos de grão de ferrita pode ser descontinuada para altas taxas de resfriamento, porém a medida que a taxa de resfriamento diminui, a austenita tende a tornar-se cada vez mais contínua. Sob baixas taxas de resfriamento a austenita intragranular com morfologia de placas tende a precipitar e podem ser nucleadas nos contornos de grão da ferrita ou nas discordâncias(VAROL, 1992). Uma taxa de resfriamento entre 1200 e $800\left(\Delta t_{12-8}\right)$ é comumente usada para quantificar o efeito das taxas de resfriamento na porcentagem de ferrita.Em virtude das taxas de resfriamento obtidas durante a soldagem, a precipitação da austenita acaba sendo controlada principalmente pela difusão do nitrogênio (HERTZMAN, 1986).A temperatura solvus da ferrita também é alterada, mas pela proporção de nitrogênio; quanto maior for essa proporção de nitrogênio, maior a temperatura solvus. Assim, nas temperaturas mais elevadas acontece a precipitação da austenita, resultando numa quantidade maior de austenita de Widmanstatten. Em contrapartida, quando o teor de nitrogênio é reduzido obtém-se uma fração volumétrica maior de austenita intragranular. 
A fração de austenita formada durante o resfriamento na região III, pode ser impactada pelo crescimento de grão ocorrido na região II, ocasionando na sua diminuição por exemplo. Isto ocorre devido à falta de área de contorno de grão, consequentemente de energia, para nucleação da austenita. A área de contorno de grãos por volume é proporcional ao potencial químico para a nucleação da austenita. Assim como outras fases podem se precipitar durante o processo de resfriamento, como fases intermetálicas, carbonetos e nitretos e a cinética de precipitação dessas fases depende tanto da composição química da liga quanto do ciclo térmico experimentado, e ainda da fração volumétrica de austenita formada (Lippold e Koteck, 2005; Londoño, 1997).

Como mencionado anteriormente, o tempo acima da temperatura solvus da ferrita tem um efeito notável no crescimento de grão da ferrita. Acima dessa temperatura, não existe nenhum impedimento efetivo para o crescimento de grão da ferrita e o tamanho desse grão cresce drasticamente. Como o tamanho de grão da ferrita tem um forte efeito na ductilidade e na dureza da liga, geralmente é recomendável minimizar esse tempo de permanência na região 2 . O tamanho de grão, tanto do metal de solda quanto da ZTA, aumenta também como uma função do aporte térmico aplicado. A figura 3.14 mostra, para o aço duplex 2205, que o tamanho de grão, tanto da zona fundida quanto da ZTA, cresce um fator perto de 5 na faixa de aporte térmico 0,25 a 1,7KJ/mm.

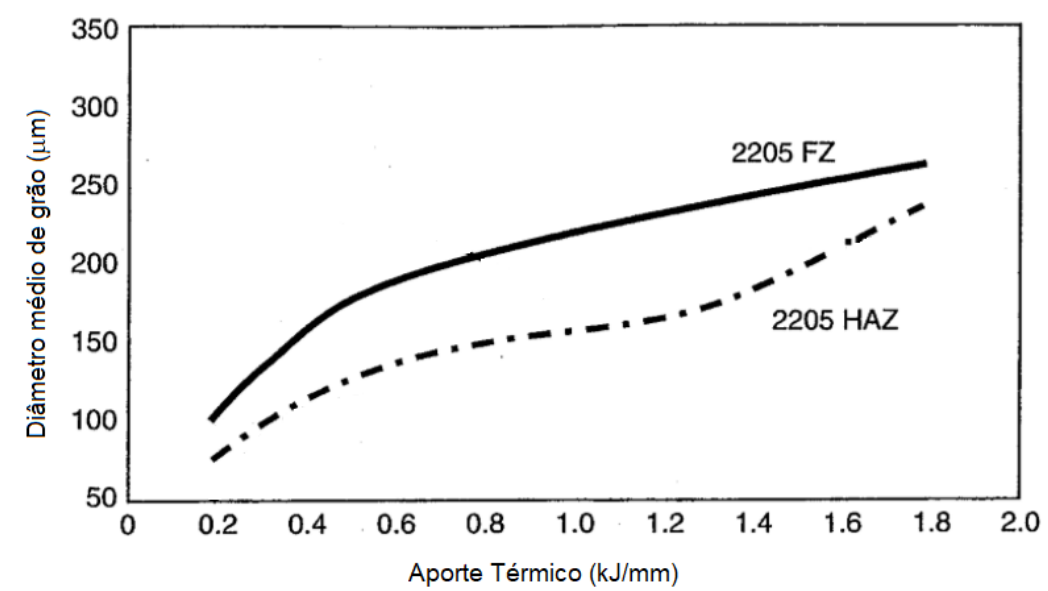

Figura 3.14: Efeito do aporte térmico (tempo acima da temperatura solvus da ferrita) no tamanho de grão da ferrita (Lippold et al., 1994 - Adaptado).

Nos extremos das taxas de resfriamento acima da temperatura solvus da ferrita, a fração de ferrita-austenita pode ser grandemente influenciada. Na 
microestrutura de uma liga quando resfriada bruscamente (de uma temperatura acima da temperatura solvus da ferrita), apenas uma pequena parte de austenita é observada nos contornos de grão da ferrita. Não existe austenita dentro dos largos grãos de ferrita que se mantiveram oriundos da temperatura acima da temperatura solvus da ferrita. Quando processos de soldagem de altas energias forem empregados, a chance de surgirem precipitados que resultam de um resfriamento brusco, aumentam. Por isso, precauções devem ser tomadas quando estes processos forem utilizados.

\subsubsection{2}

\section{Zona Termicamente Afetada de Temperatura Baixa (ZTATB)}

A ZTATB é definida entre as temperaturas solvus da ferrita e a ambiente, e acrescenta-se a temperatura onde as frações volumétricas de ferrita e austenita são as de equilíbrio $(T \alpha / \gamma)$ e a faixa de temperatura de precipitação de algumas fases.

Na região I acontece a dissolução parcial da austenita, já a sua precipitação irá depender da taxa de resfriamento empregada no processo. Os grãos de austenita não dissolvidos atuam como barreira para o crescimento do grão ferrítico (ATAMERT, 1992). No processo de resfriamento, o crescimento da austenita acaba sendo favorecido pelos grãos não totalmente dissolvidos e tem-se nesta região a fração de austenita maior que na ZTATE, em face disso a precipitação intragranular de nitretos é muito menor.

A região II é delimitada pelas temperaturas extremas (máxima e mínima) de precipitação de algumas fases, onde essa precipitação depende do tempo de permanência nesta faixa de temperatura e da cinética da transformação.

A FIG. 3.15 apresenta um exemplo dos ciclos térmicos em duas zonas na ZTATB. Na primeira zona a temperatura máxima foi acima de $(T \alpha / \gamma)$, podendo, assim, distinguir as duas regiões do ciclo térmico. O segundo ciclo térmico representa uma zona da ZTATB onde a temperatura máxima está determinada dentro do intervalo de precipitação da fase de interesse, não se pode distinguir duas regiões para este caso, ficando apenas com a região II do ciclo térmico. 


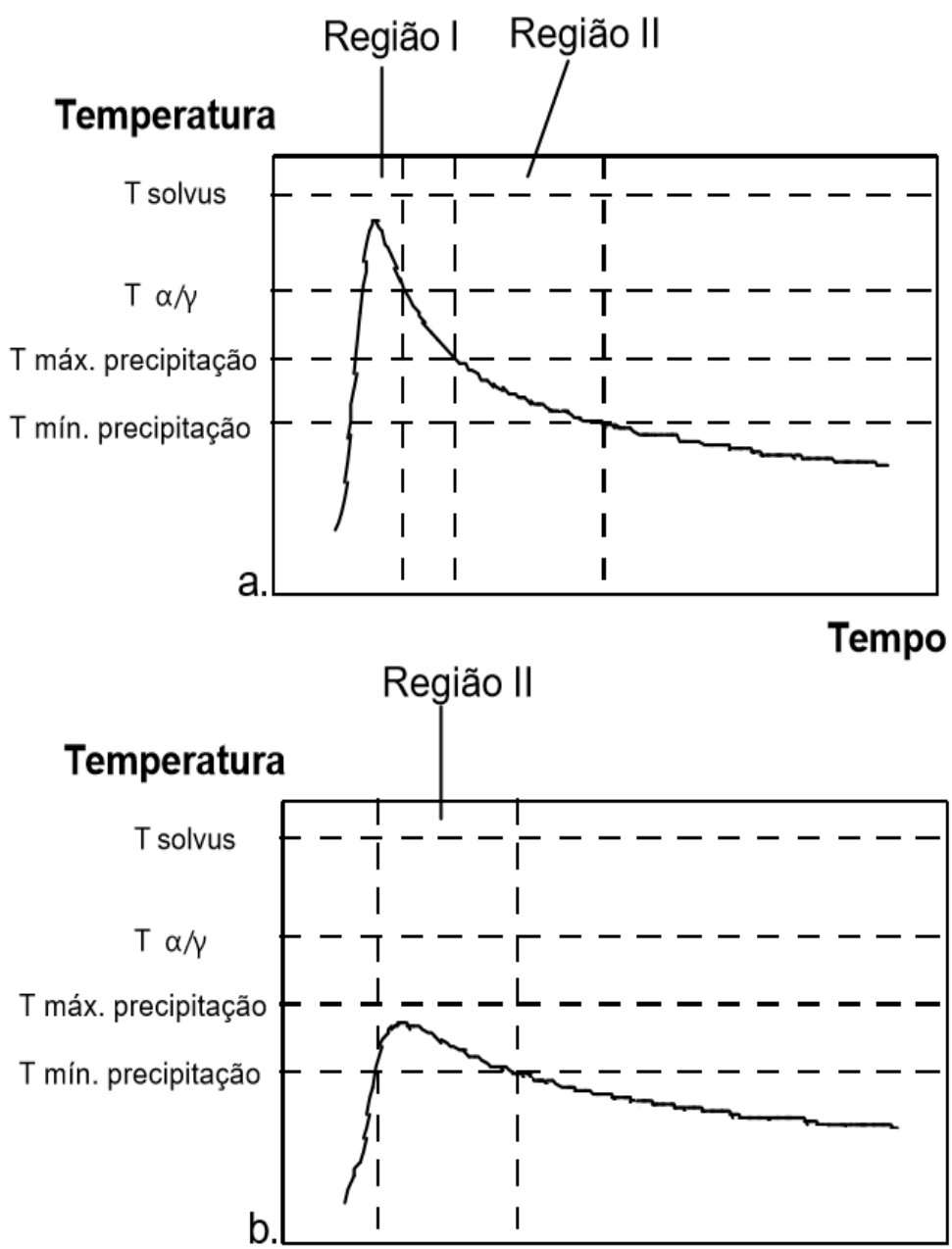

Tempo

Figura 3.15: Distintos casos mostrando regiões relevantes de um ciclo térmico de soldagem na ZTATB. (a) Quando a temperatura máxima ultrapassa $(T \alpha / \gamma)$ e (b) quando a temperatura máxima está determinada dentro do intervalo de precipitação de uma fase deletéria.

A FIG. 3.15, demonstra que a ZTATB pode ser dividida em 2 situações, que dependem da temperatura máxima atingida na região: uma onde ocorre a variação das frações volumétricas da ferrita e da austenita, e outra onde essas frações são praticamente constantes. Nitretos e/ou outras fases intermetálicas podem sofrer precipitação na segunda situação, devido a taxas de resfriamento muito baixas ou quando a junta soldada é submetida a reaquecimento, como uma soldagem multipasse, por exemplo. 


\subsection{3}

\section{Controlando as Frações Ferrita - Austenita}

A fração de ferrita no metal de base é controlada através de uma combinação de composições químicas e condições térmicas de soldagens. Para superar os efeitos de uma taxa de resfriamento rápida que pode promover uma fração maior de ferrita do que aquela ótima desejada, muitos metais de adição contêm níveis mais elevados de níquel do que o metal base. Níveis elevados de níquel e/ou nitrogênio permitem que a austenita seja formada em temperaturas mais altas devido ao aumento da temperatura solvus da ferrita. Também promove a formação da austenita mais rapidamente durante o resfriamento.

Uma vez que o metal de base é escolhido, o balanço de ferrita-austenita na ZTA pode ser controlado ajustando o ciclo térmico a ser utilizado e o gás de proteção. Taxas rápidas de resfriamento como consequência de um baixo aporte térmico utilizado ou em seções estreitas do material podem resultar em uma ZTA altamente ferrítica adjacente à linha de fusão.

\subsection{4}

\section{Metal de Solda}

Os mecanismos de transformação no estado sólido para o MS são similares aos que ocorrem na ZTA. Tem-se que no MS as frações de austenita intragranular são maiores, devido a maior quantidade de inclusões ocorridas nesta região, o que se torna uma via preferencial para a nucleação deste tipo de austenita

O crescimento epitaxial a partir dos grãos de ferrita pré-existentes da zona de ligação, que ocorre durante a solidificação da poça de fusão, produzem uma estrutura colunar grosseira de grãos de ferrita no MS portanto o tamanho do grão da ZTATE tem influência determinante na microestrutura do MS, figura 3.16.

A austenita precipita no MS de maneira similar àquela que acontece na ZTATE, durante o resfriamento. O crescimento epitaxial é explicado pelos gradientes térmicos elevados e o contato direto entre o líquido e o sólido de composições e/ou estruturas semelhantes, existentes na poça de fusão.

A solidificação da poça de fusão tem por característica o crescimento competitivo entre grãos adjacentes, uma vez que estes crescem a partir de 
estruturas previamente já existentes. Como o crescimento é favorecido na direção do maior gradiente térmico, os grãos tendem a crescer primeiro segundo essa orientação. Esse fato pode ocasionar o impedimento do crescimento ou coalescimento de novos e menores grãos.

As propriedades finais da junta soldada são influenciadas pelo tamanho do grão, orientação, fração volumétrica e morfologia de ambas as fases presentes nessa região. Quando em quantidades excessivas, a ferrita altera as propriedades mecânicas da junta soldada, e para diminuir as alterações na estrutura da ZF recomenda-se que haja uma certa quantidade de austenita em temperatura ambiente. Uma vez que a nucleação da austenita é favorecida pelos contornos de grão, grão de tamanho diminuto tendem assim promover maiores teores de austenita. Em geral as soldas de aços inoxidáveis duplex têm teor de ferrita na faixa de 30 70\% dependendo da composição e das taxas de resfriamento (Gunn, 2003).

O controle da fração de austenita no MS pode ser ajustado através do metal de adição e do gás de proteção afim de controlar a precipitação de nitretos de cromo. O processo de soldagem deve ser, de maneira geral, controlado para assegurar que o resfriamento seja lento o suficiente a fim de permitir a formação da austenita na ZTA, e rápida o bastante para evitar precipitações de fases indesejadas na região (BRANDI, 1992).

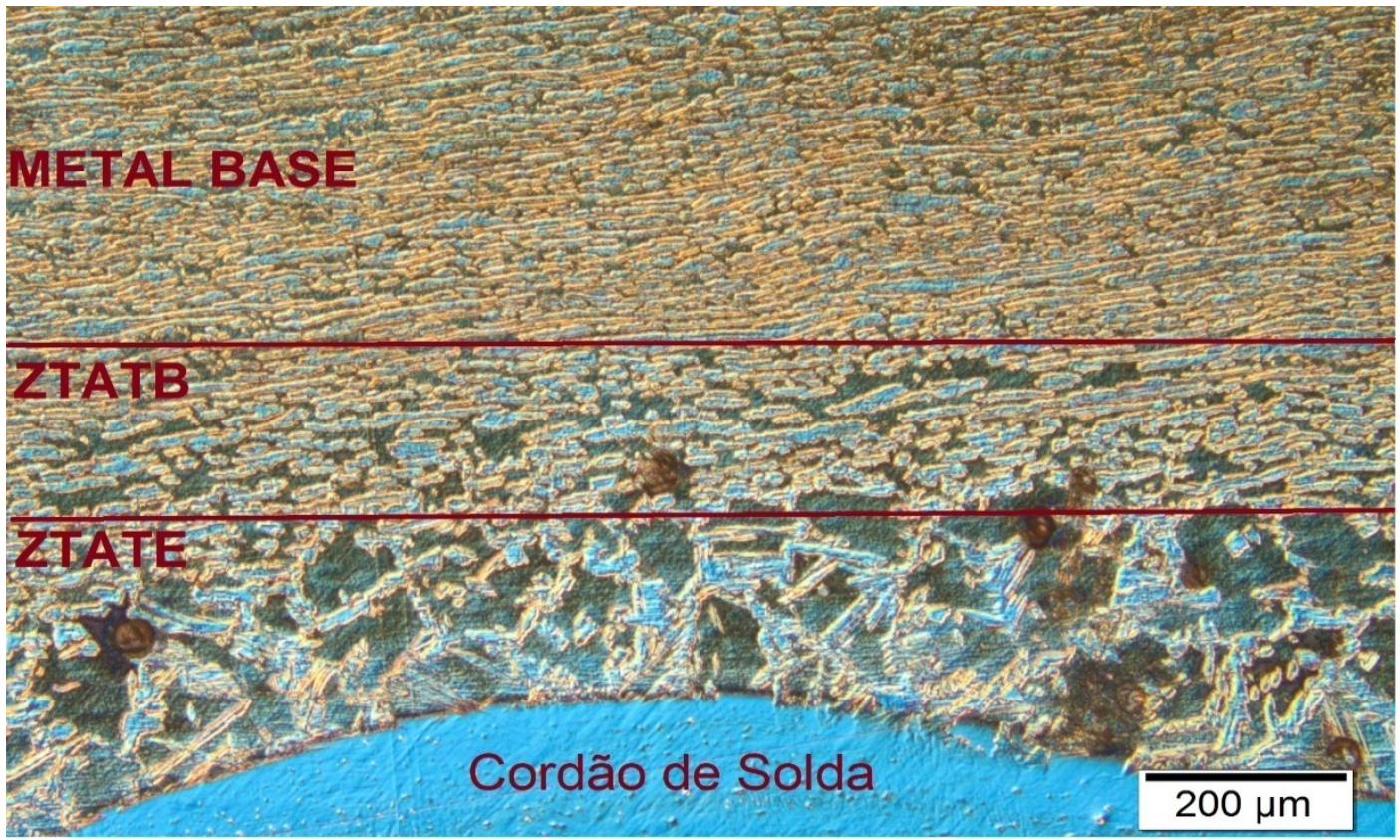

Figura 3.16: Imagem de um aço inoxidável duplex, ilustrando a separação adotada para a ZTA, em temperatura alta (região com crescimento de grão) e temperatura baixa (desbalanço das frações de fase). 


\section{4 \\ Modelagem do Processo de Soldagem - Aproximações}

A modelagem do processo de soldagem é uma tarefa complexa que envolve o acoplamento de diversos fenômenos, sendo os principais: o térmico, o mecânico e o de transformação de fase. O processo envolve ainda a presença de não-linearidades constitutivas e geométricas. As primeiras estão associadas à dependência da temperatura das propriedades termomecânicas, enquanto as segundas a grandes deslocamentos. A fonte de calor localizada promove uma forte localização do processo que apresenta elevados gradientes das variáveis envolvidas, além de elevadas taxas.

Em função das complexidades presentes, normalmente é necessário que algumas hipóteses e aproximações sejam consideradas para simplificar o modelo, de modo a tornar viável o desenvolvimento de simulações numéricas utilizando abordagens como as baseadas no método de elementos finitos.

Neste trabalho considera-se que o metal de base e o material de solda apresentam as mesmas propriedades termomecânicas e que estas não são alteradas pelo processo. Pequenas alterações podem ocorrer devido às transformações de fase presentes e de variações de composição química. No entanto, considera-se que as propriedades termomecânicas dependem da temperatura. Isto afeta o comportamento observado durante o processo, no que diz respeito a questões como o desenvolvimento de deformações plásticas do material, além do processo de transferência de calor (BONIFAZ, 2000).

Além disso, considera-se que a poça de fusão é considerada uma região de tensão zero, bem como as regiões onde as temperaturas excedem as temperaturas de fusão do material. Finalmente, não são consideradas tensões resultantes de nenhum processo de fabricação anterior a que a chapa foi submetida. 


\section{1}

\section{Modelo da Fonte de Calor - Introdução}

Nas modelagens do processo de soldagem, a descrição precisa da fonte de calor é um fator essencial para que se obtenha uma previsão adequada das temperaturas e tensões que se desenvolvem ao longo do processo. Diversas abordagens podem ser encontradas na literatura.

Em 1946 Rosenthal(1946) apresentou uma solução para a distribuição de temperatura de uma fonte de calor em deslocamento sobre uma chapa. Este modelo analítico serviu de base para a maioria dos estudos subsequentes sobre fluxo de calor. Resultados experimentais indicam que a equação proposta por Rosenthal apresenta boa concordância com o tamanho real da ZTA, mas não fornece informações detalhadas sobre a forma da poça de fusão. A equação de Rosenthal para um processo de condução de calor tridimensional em uma placa semi-infinita é dada por:

$$
T-T_{0}=\frac{q}{2 \pi k R} e^{-\frac{v(x+R)}{2 \alpha}}
$$

A equação acima denota a distribuição de temperatura, considerando um sistema de coordenadas retangulares, com o eixo $x$ paralelo à direção de soldagem (FIG. 4.1), e com a fonte de calor deslocando-se a uma velocidadevsobre a superfície da placa. A potência máxima gerada durante a soldagem pode ser determinada através da equação:

$$
P=V I \eta
$$

Onde $P$ é a potência, $V$ a diferença de potencial, $I$ a corrente elétrica e $\eta$ a eficiência do processo. A condutividade e a difusividade térmicas da peça são representadas respectivamente por $k$ e $\alpha, T_{0}$ é a temperatura inicial da peça e

$$
R=\left(x^{2}+y^{2}+z^{2}\right)^{\frac{1}{2}}
$$




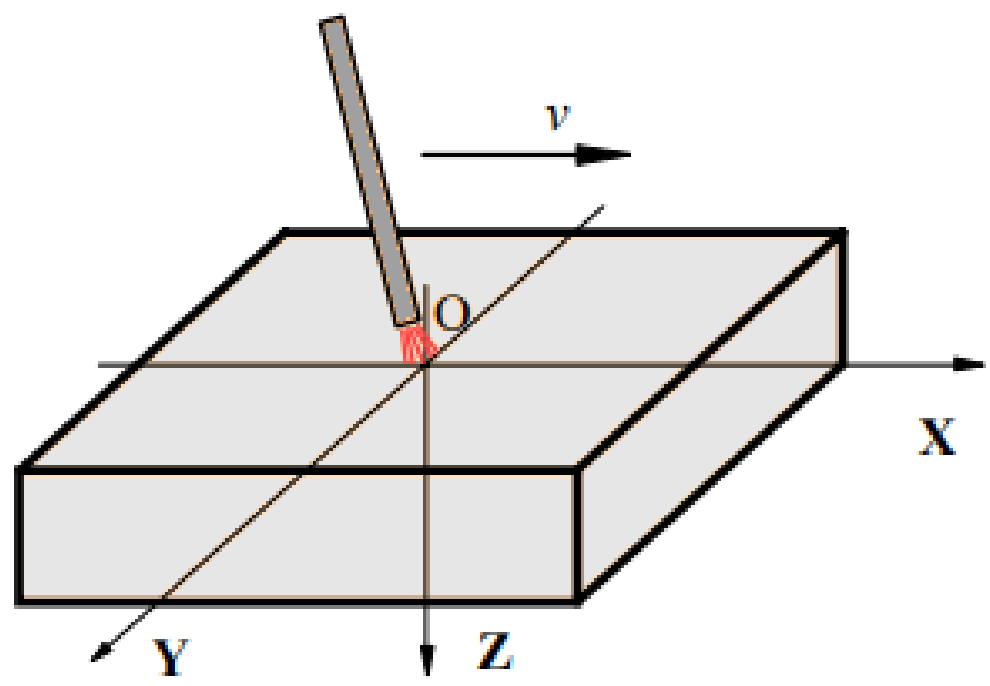

Figura 4.1: Representação do sistema de coordenadas para obtenção do sistema quaseestacionário.

A equação de Rosenthal tende a prever a profundidade da solda e a subestimar a largura da solda em função das simplificações assumidas no modelo, a saber:

A fonte de calor é tida como um ponto aplicado na superfície da chapa - sendo que através desse ponto de aplicação da fonte térmica, existe a deposição do material;

A solução encontrada é válida para um sistema em estado quaseestacionário - onde supõe-se que a distribuição de temperaturas se mantém inalterada para um sistema de coordenadas arbitrário que se move junto com a fonte de calor, tornando assim o problema independente do tempo;

$>$ A peça a ser soldada possui uma geometria simplificada - onde comprimento, largura e muitas vezes a espessura da peça são infinitos. Eliminando assim a questão do efeito de borda, fato que poderia ocasionar em uma maior dificuldade de se chegar à solução do problema;

As propriedades físicas dos materiais são consideradas constantes diversas propriedades (como condutibilidade térmica, calor específico e até mesmo a densidade) variam fortemente com a temperatura, mas admitir essa variação na solução do problema, 
tornaria o processo muito mais complexo;

As perdas de calor do material por condução e radiação térmicas são desprezadas - a solução do modelo não leva em conta a perda de calor do material através dessas duas condições, pois também aumentaria muito a complexidade da própria solução.

Este modelo adotado para a fonte de calor, fornece uma entrada de calor extremamente elevada ao modelo, próximo ao ponto onde essa fonte de calor se encontra. A solução também fornece representações não realistas da ZTA do material. Ainda assim, devido às simplificações adotadas, as soluções fornecem uma representação aproximada da distribuição de temperatura em uma solda a ser avaliada. Estas soluções permitem, de maneira geral, obter uma ideia das características do fluxo de calor em soldagem para muitos casos.

Em trabalho posterior, Christensen (CHRISTENSEN, 1965) foi capaz de reduzir as equações de Rosenthal a uma forma adimensional e comparou as dimensões (área, largura e penetração) do cordão de solda previstas pelo modelo anterior com um grande número de dados experimentais. Foram realizados testes com alumínio e aço, para diferentes condições de soldagem, obtendo-se também como resultado a velocidade média de resfriamento. $\mathrm{O}$ autor concluiu que seu modelo é adequado para prever tendências em termos das dimensões da solda, mesmo existindo uma vasta dispersão em alguns resultados comparados aos dados experimentais.

Logo após foram propostos os modelos de fluxo de calor distribuído de Pavelic (PAVELIC, 1969) e Rykalin (RYKALYN, 1974), introduzindo o caráter da função de distribuição do fluxo de calor. Os modelos concebidos por esses autores são, de maneira geral, bastante efetivos para baixos aportes de soldagem, significando que tais modelos não podem ser empregados para soldagem a laser, por elétrons ou plasma. No entanto, nesses modelos puderam ser incluídas características importantes como a não linearidade das propriedades dos materiais e a evolução da microestrutura do mesmo. Mesmo sendo mais apurados do que o modelo proposto por Rosenthal, ainda não descrevem de maneira adequada a largura e a penetração do cordão de solda.

Anos mais tarde, Eagar e Tsai (EAGAR e TSAI, 1983) apresentaram uma solução para uma fonte de calor em uma placa semi-infinita, onde a única 
diferença para o modelo apresentado por Rosenthal é a inclusão de uma distribuição da fonte de calor através de uma representação gaussiana (FIG. 4.2). Esta teoria da fonte de calor distribuída forneceu a primeira estimativa da geometria da poça de solda com base nos fundamentos da transferência de calor. Para este modelo, os mesmos pressupostos que Rosenthal fez foram utilizados, a saber: a ausência de perdas de calor na forma de convecção e radiação térmicas, propriedades térmicas constantes do material e um meio semi-infinito. A equação de Eager e Tsai é dada por:

$$
Q(x, y)=\frac{q}{2 \pi \sigma^{2}} e^{\frac{-\left(x^{2}+y^{2}\right)}{2 \alpha}}
$$

Onde $Q(x, y)$ representa a distribuição de potência empregada e $\sigma$ é o desvio padrão da função gaussiana adotada no modelo.

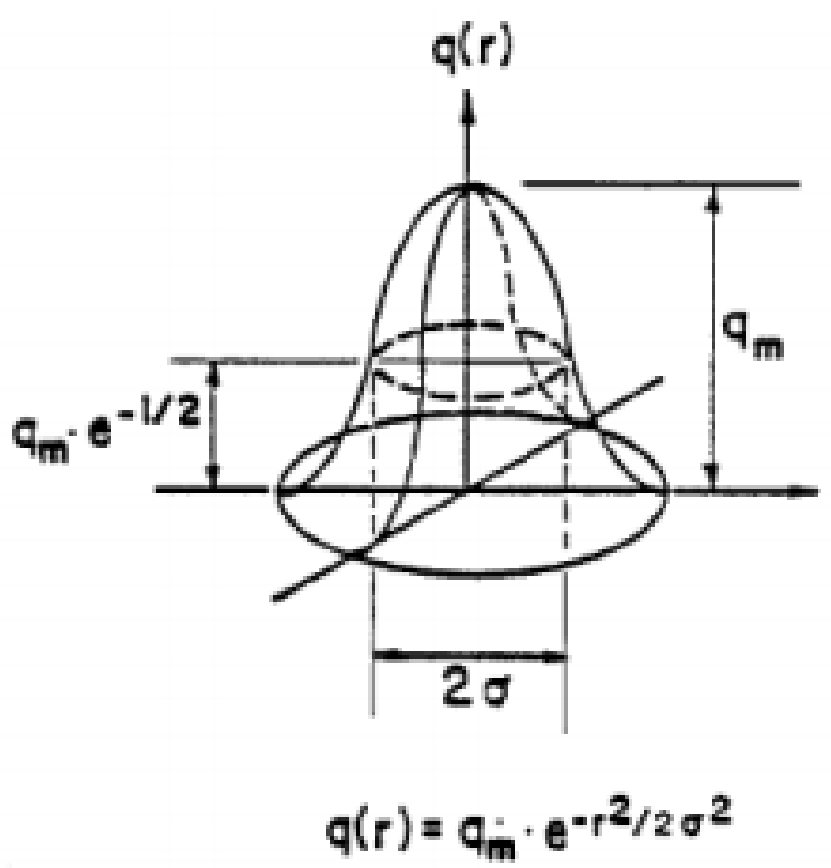

Figura 4.2: Distribuição Gaussiana do fluxo de calor gerado no processo de soldagem sugerido por Eagar e Tsai (EAGAR e TSAI, 1983).

A teoria fornecida apresenta uma boa correlação com experimentos feitos em aço carbono, aço inoxidável, alumínio e titânio. Somente a profundidade de solda não apresenta uma boa correlação com os experimentos. Um fator de aprimoramento, que estimou o perfil de temperatura de placas de espessura finita, 
propostas por Myers (citado por EAGAR e TSAI, 1983), apresenta uma concordância muito melhor com os experimentos. A perda de calor devido à radiação, à condução através do eletrodo e o calor consumido para a queima do fluxo e fusão do eletrodo foram consideradas através da introdução do parâmetro de eficiência do arco $\eta$, associada ao processo de soldagem (ADAK, 2003).

Outros trabalhos indicaram que, em termos dos perfis da distribuição de temperaturas em torno da região da solda, os resultados apresentados por Rosenthal têm uma maior validade para os pontos mais afastados da fonte de calor, não sendo bem descrito onde o gradiente de temperatura é significativo. O modelo descrito por Rosenthal e por alguns autores subsequentes, desconsideraram a convecção do material na poça de fusão e sua possível influência no formato final do cordão de solda. Este efeito foi evidenciado por outros autores como HALMOY (1979), que associou a formação geométrica do perfil de penetração em “dedo” (finger-typepenetration) com a transferência de momento das gotas de metal de adição para a poça, efeito típico da transferência em spray no processo GMAW. Já HEIPER e ROPER (1982) associaram a variação de penetração em soldagem GTAW mecanizada de aços inoxidáveis com o efeito de elementos tenso-ativos (como o enxofre e o oxigênio em particular) sobre a convecção na poça de fusão.

Tsai e Eagar (1985) mediram a eficiência do arco para a soldagem a arco com eletrodo não consumível de Tungstênio (TIG) em um ânodo de cobre arrefecido a água. A eficiência do arco foi determinada pela medição do calor que chegou ao ânodo de cobre dividido pelo calor total produzido pelo arco. O calor foi calculado como sendo 80\% do calor gerado no arco. Esta eficiência do arco foi muito maior do que a eficiência do arco de uma solda normal quando uma poça fundida estivesse presente. Tsai também investigou os efeitos dos comprimentos de arco e provou ser este o parâmetro primário que governa as distribuições de calor, enquanto a corrente dominou a magnitude do fluxo de calor. Uma mudança no comprimento do arco influencia o parâmetro de distribuição de calor, $\sigma$, da equação (4.2).Pode-se observar que o fluxo de calor cairá mais rapidamente com um menor valor $\sigma$. A representação do parâmetro de distribuição de calor, $\sigma$, é mostrada na Figura 4.2. 


\subsection{1}

\section{Modelo da Fonte de Calor Duplo Elipsoide de Goldak}

Goldak (GOLDAK, 1983) introduziu pela primeira vez um modelo de fonte de calor tridimensional com formato geométrico de dupla elipsoide em movimento (FIG. 4.3). Para essa abordagem, a distribuição do calor é considerada do tipo Gaussiana (na qual o fluxo de calor é distribuído pelo volume da fonte de calor) e duas semi-elipsóides (uma a frente e outra atrás da fonte de calor) delimitam a distribuição da temperatura.

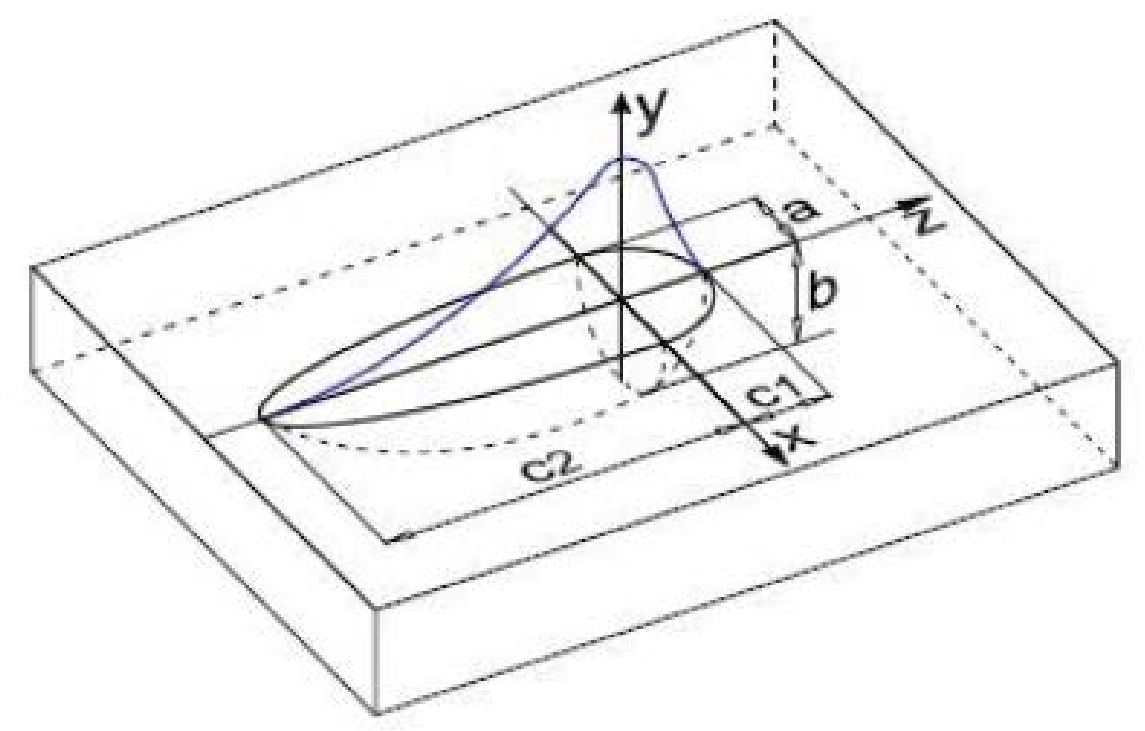

Figura 4.3: Modelo de distribuição de calor apresentada por Goldak (GOLDAK, 1983).

Uma modelagem baseada no método de elementos finitos foi utilizada por Goldak para estimar o campo de temperatura de um cordão de solda depositado sobre uma placa. $\mathrm{O}$ autor mostrou que esta fonte de calor tridimensional pode eliminar a deficiência associada aos modelos simples gaussianos bidimensionais, conhecidos até então, em relação à previsão da temperatura das juntas soldadas com penetração profunda. A equação de modelo de fonte proposta por Goldak é dada por:

$$
Q(x, y, z)=\frac{6 \sqrt{3} r Q}{a b c \pi \sqrt{\pi}} \exp \left(-\frac{3 x^{2}}{a^{2}}-\frac{3 y^{2}}{b^{2}}-\frac{3 z^{2}}{c^{2}}\right)
$$


Onde $a, b, c$ - representam parâmetros geométricos da elipsoide quando a fonte de calor está situada nas coordenadas $(0,0,0)$ naquele instante de tempo;

A fonte de calor proposta por Goldak consiste em dois volumes semielipsoidais diferentes que foram combinados para dar o novo fluxo de calor. O fluxo de calor para assemi-elipsóides frontal e traseira é representado, respectivamente, pelas seguintes equações:

$$
\begin{aligned}
& q_{f}(x, y, z, t)=\frac{6 \sqrt{3} f_{f} Q}{a b c_{1} \pi \sqrt{\pi}} e^{\frac{-3 x^{2}}{a^{2}}} e^{\frac{-3 y^{2}}{b^{2}}} e^{\frac{-3[z+v(\tau-t)]^{2}}{c_{1}^{2}}} \\
& q_{r}(x, y, z, t)=\frac{6 \sqrt{3} f_{r} Q}{a b c_{2} \pi \sqrt{\pi}} e^{\frac{-3 x^{2}}{a^{2}}} e^{\frac{-3 y^{2}}{b^{2}}} e^{\frac{-3[z+v(\tau-t)]^{2}}{c_{2}^{2}}}
\end{aligned}
$$

Os índices $a$, $b$ e $c$ nas equações (4.4) e (4.5) são parâmetros geométricos já discutidos, que buscam descrever o tamanho da poça de fusão empregada no processo de soldagem. Estes parâmetros podem ser estimados de forma experimental (NGUYEN, 1999) pela medição dos limites da zona fundida através de um ensaio metalográfico por exemplo, sendo usados assim para iniciar o processo de calibração do modelo numérico. Para $f_{f}$ e $f_{r}$, que são os coeficientes adimensionais de proporção de aporte de calor na parte a frente e atrás da fonte, deve-se satisfazer a relação: $f_{f}+f_{r}=2$. Na ausência de dados melhores, ou experimentais, a distância na frente da fonte de calor pode ser tomada como a metade da largura do cordão de solda e a distância atrás da fonte de calor como sendo igual ao dobro da largura do cordão de solda (GOLDAK, 1984).

\subsection{2}

\section{Geração da malha do modelo x Tempo computacional}

O custo computacional de preparação de uma malha refinada o suficiente para garantir uma análise precisa com elementos finitos é relativamente baixo em comparação com os custos de computação. Goldak (GOLDAK, 1986) aponta para uma importante condição que deve ser utilizada na elaboração da malha: a malha deve ser suficientemente refinada para representar a fonte de calor com a precisão 
adequada e desejada. O autor estabelece de maneira generalizada que ao menos quatro elementos geométricos deveriam ser usados ao longo de cada eixo apresentado, a fim de capturar a inflexão da distribuição gaussiana com um mínimo de precisão requerida pelo modelo.

Ao gerar a malha do modelo, deve-se analisar o nível de detalhamento da mesma com o objetivo de garantir que a análise seja realizada adequadamente a fim de cumprir seu propósito, com o menor custo computacional possível. Logo, uma boa malha é aquela que apresenta elementos geométricos adequados, pouco distorcidos e deformados e esta métrica podendo ser avaliada por meio de algum dado substancial.

Goldak afirma que se pretendemos estudar em detalhe a região próxima à poça de fusão, este modelo de duplo elipsoide pode ser muito favorável, especialmente combinado com uma malha previamente refinada, contendo assim cerca de dez elementos lineares ao longo do eixo da área elipsoidal de entrada de calor (BARAN, 1988). Este mesmo autor afirma que a fonte de calor deve avançar no máximo cerca de metade do seu comprimento para garantir a precisão dos resultados, definindo assim o passo de tempo empregado no modelo.

O tamanho do passo de tempo influencia drasticamente a precisão do modelo de fonte de calor. Goldak propôs que a fonte de calor deve se mover no máximo aproximadamente a metade do seu comprimento durante um único passo de tempo para determinados modelos (GOLDAK, 1986). Uma sucinta descrição de um passo de tempo otimizado é descrita na próxima seção.

\subsection{3}

\section{Passo de Tempo}

A fim de evitar resultados imprecisos ou soluções instáveis durante as simulações numéricas, é necessária a escolha adequada do passo de tempo. Uma série de fatores, incluindo o tamanho espacial do elemento da malha e a difusividade térmica do material empregado, devem ser levados em conta na escolha do passo de tempo pois influenciam diretamente a precisão do modelo de fonte de calor. Dependendo das condições, a utilização de passos de tempo muito pequenos pode levar a resultados fisicamente inadmissíveis, como o estabelecimento de fluxos de calor de regiões de temperatura mais baixa para 
regiões de temperatura mais elevada.

A utilização de um passo de tempo grande, gera imprecisão na representação de gradientes e taxas elevados. Além disso, um passo de tempo demasiadamente grande pode levar a situações nas quais elementos da malha não sejam corretamente submetidos aos níveis de energia corretos durante a passagem da fonte de calor no processo de soldagem.

Goldak em seus trabalhos propõe que o passo seja escolhido de modo que a fonte de calor se mova uma distância aproximadamente igual à metade do comprimento de um elemento durante a realização da solda, a cada passo de tempo.

Assim como no caso da discretização espacial, para a discretização temporal é necessário desenvolver uma análise de convergência para que os resultados possam ser considerados confiáveis sob o ponto de vista de análise numérica.

\subsection{4}

\section{Condições de Perda de Calor}

Em um processo de soldagem qualquer, acontece o aquecimento localizado de uma determinada região do material com a passagem da fonte de calor. Em função deste aquecimento localizado, estabelecem-se gradientes de temperatura que provocam o aquecimento por condução de outras regiões da peça. Após a passagem da fonte, observa-se o resfriamento da peça, em grande parte, por transferência de calor com outras regiões da peça e com o meio. O processo de transferência de calor pode ocorrer segundo três mecanismos distintos, a saber: condução, convecção e radiação.

\subsubsection{1}

\section{Condução}

Propagação do calor consiste na transferência de energia térmica entre as regiões de um material. Na condução, o processo é basicamente molecular, de contato, e a transferência do calor é bastante eficiente em meios densos. Este mecanismo é o responsável pelo calor se deslocar dentro do material que está 
sendo soldado, pelos ciclos térmicos serem dependentes dos deslocamentos e da distância da fonte térmica. O fluxo de calor conduzido através de um determinado material (em uma direção) é dado pela lei de Fourier, da seguinte maneira:

$$
q_{\operatorname{cond}_{(x)}}=-k \frac{\partial T}{\partial x}
$$

onde $k$ é a condutividade térmica do material e $\frac{\partial T}{\partial x}$ é o gradiente de temperatura em uma determinada direção do material, aqui representada pela direção $x$.

O sinal negativo na expressão indica que o fluxo de calor é contrário ao gradiente de temperatura estabelecido no material, ou seja, o fluxo de calor ocorre da região de maior temperatura para a região de menor temperatura.

\subsubsection{2 \\ Convecção}

O mecanismo de transferência de calor por convecção acontece quando um sistema realiza troca térmica com outro através de um meio fluido. Assim durante a realização de um processo de soldagem, estando o corpo de prova a ser soldado sempre imerso em um meio fluido, significa que este mecanismo será efetivo e estará atuante.

Para os processos convectivos, independentemente da natureza específica do processo, existindo transferência de calor por convecção, pode-se descrever este modo de transferência de calor através da Lei de Newton do Resfriamento, da seguinte maneira:

$$
q_{\text {conv }}=h_{\text {conv }}\left(T_{S}-T_{a m b}\right)
$$

onde o fluxo de calor convectivo $q$, é proporcional à diferença entre temperaturas da superfície do objeto em questão e do fluido em contato com o objeto.

O parâmetro “ $h_{\text {conv }}$ ” é chamado de coeficiente de transferência de calor por convecção. Este parâmetro é dependente das condições empregadas no meio de resfriamento para as camadas de fluido, as quais, por sua vez, são influenciadas pela geometria das superfícies da amostra. A natureza do escoamento do fluido e uma série de propriedades termodinâmicas e de transporte do fluido também 
exercem influência sobre as condições de resfriamento (INCROPERA, 1998).

\subsubsection{3}

\section{Radiação}

Em se tratando da transferência de calor por radiação, o transporte de energia térmica é realizado por ondas eletromagnéticas, não sendo necessário meio material para sua propagação, diferentemente da condução e da convecção que necessitam de um meio para ocorrer. Qualquer objeto com temperatura superior a $-273^{\circ} \mathrm{C}(0 \mathrm{~K})$, ou zero absoluto, emite radiação.

A taxa de energia em um determinado ponto ou por unidade de área liberada neste modo de transmissão de calor é conhecida como poder emissivo da superfície em análise. A lei de Stefan-Boltzmann que rege a transferência de calor por radiação, pode ser escrita como o fluxo de calor radioativo:

$$
q_{r a d}=\varepsilon \sigma\left(T_{S}^{4}-T_{a m b}^{4}\right)
$$

sendo $T_{S}$ a temperatura absoluta $(\mathrm{K})$ da superfície e $\sigma$ é a constante de StefanBoltzmann $\left(5,669 \times 10^{-8} \mathrm{~W} /\left(\mathrm{m}^{2} \cdot \mathrm{K}^{4}\right)\right.$. Como uma superfície real difere de um corpo negro, para o qual toda energia pode ser emitida, o fluxo térmico emitido é menor considerando a mesma temperatura. A levar em consideração esse fato, adota-se um índice de emissividade que depende de cada material, $\varepsilon$, onde seu valor pode variar de 0 a 1 , fornecendo a eficiência com que a superfície emite radiação.

\subsubsection{4}

\section{Coeficiente de transferência de calor combinado}

Muitos pesquisadores usam em seus trabalhos um coeficiente de transferência (perda) de calor combinado por convecção e radiação (BONIFAZ, 2000). Este fato permitiu o uso de uma condição limite para a perda de calor em vez de utilizar duas. Rykalin propôs em seu trabalho, um coeficiente de transferência de calor como descrito na Equação 3.9 (RYKALIN, 1974). 


$$
h_{c o m b}=24.1 \times 10^{-4} \varepsilon T^{1.61}
$$

Goldak comenta em seus trabalhos que a utilização desta equação não fornece resultados tão precisos quanto a aplicação das equações de Newton para o resfriamento (convecção) e a equação de Stefan-Boltzmann para a radiação, de maneira separada, com os coeficientes apropriados. A transferência de calor através da radiação é proporcional à quarta potência da diferença de temperatura e só se torna significativa a temperaturas muito elevadas $\left(\sim>800^{\circ} \mathrm{C}\right)$. Alguns autores ignoram as perdas de calor por radiação nos corpos de prova simulados, quando o objetivo é o de estudar, por exemplo, apenas tensões residuais, uma vez que este fato não influencia nos resultados esperados e comumente incorporam-na no fator de eficiência do arco (FRANCIS, 2002). 


\section{Modelo Numérico Desenvolvido}

A fim de avaliar os ciclos térmicos sob determinadas condições específicas foram desenvolvidos modelos tridimensionais baseados no método de elementos finitos. Esses modelos tridimensionais permitem análises puramente térmicas dos fenômenos físicos envolvidos nos processos de soldagem.

Para representar a fonte de calor associada à fonte de soldagem utilizou-se o modelo proposto por Goldak, como já citado anteriormente. Para todos os modelos tridimensionais desenvolvidos considera-se a equação (X) que utiliza um sistema de coordenadas móvel no centro da fonte e um fixado sobre um plano de referência. Para o processo térmico empregado, os modelos consideram os fenômenos térmicos de geração de calor pela fonte de calor, além dos fenômenos de transferência de calor por condução (no material) e a perda de calor para o meio por convecção e radiação.

A análise térmica compreende 2 momentos, a saber: Soldagem $e$ Resfriamento. O período de Soldagem é compreendido pelo tempo em que o modelo da fonte de calor é aplicado ao modelo, através de um termo de geração na equação da energia, juntamente com os demais fenômenos de transferência de calor, com o intuito de gerar uma distribuição de fluxo de calor sobre a chapa. Após a passagem da fonte de calor, tem-se o momento do Resfriamento, onde o termo de geração de calor é retirado, assim a chapa é submetida aos fenômenos de transferência de calor com o meio externo por convecção e radiação.

\section{1}

\section{Descrição da Geometria}

Os modelos foram desenvolvidos utilizando rotinas na linguagem de programação paramétrica APDL do pacote computacional de elementos finitos ANSYS (ANSYS, 2015). As rotinas desenvolvidas em APDL incluem o modelo da fonte de calor, as condições geométricas, assim como os fenômenos de trocas de calor. 
As chapas modeladas possuem duas geometrias distintas, descritas na Tab. 5.1, afim de avaliar o efeito da geometria nos ciclos térmicos para os determinados aportes térmicos. Foi realizado um processo de soldagem com um cordão sobre chapa, sem chanfro empregado.

Tabela 5.1: Geometrias utilizadas nos modelos numéricos.

\begin{tabular}{|c|c|c|}
\hline Comprimento (mm) & Largura (mm) & Espessura (mm) \\
\hline 150 & 300 & 10 \\
150 & 150 & 10 \\
\hline
\end{tabular}

Para a confecção da geometria inicial, utilizam-se pontos de referência, onde o modelo é construído. Estes pontos, chamados de "key-points" são a base de formação da geometria, e as áreas são atribuídas a estes pontos, como mostrado na FIG. 5.1.

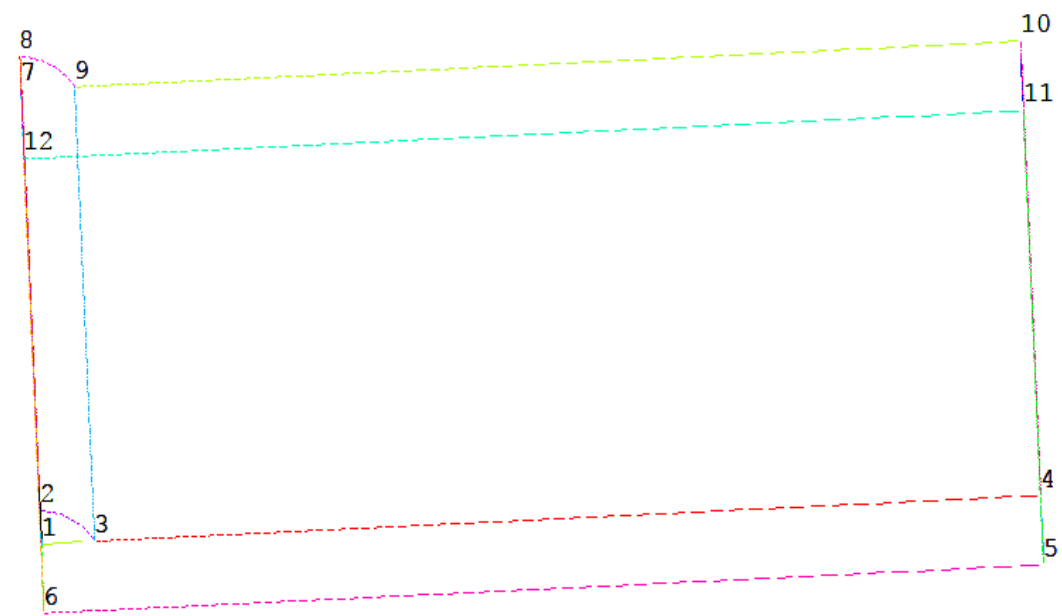

Figura 5.1: Key-points onde as áreas serão atribuídas.

Na FIG. 5.2 é mostrada as duas geometrias expandidas utilizadas no modelo numérico. 


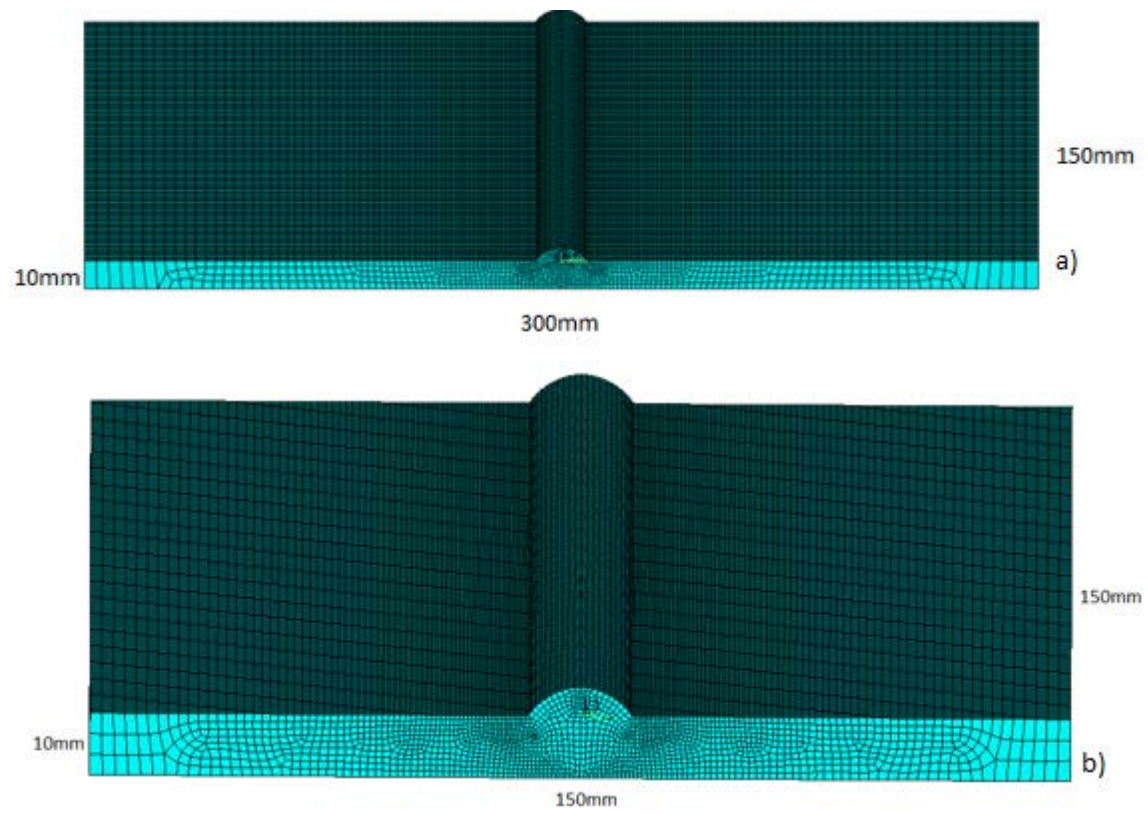

Figura 5.2: Exemplo das geometrias expandidas utilizadas nos modelos numéricos; a)

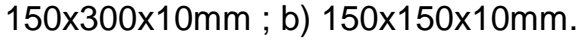

A fim de reduzir custos computacionais no modelo em elementos finitos, foi considerada uma condição de simetria no plano "xy" (para condições de contorno e geometria), que passa pelo centro do cordão de solda, reduzindo a análise numérica a apenas metade da chapa como visto na figura (FIG. 5.3).

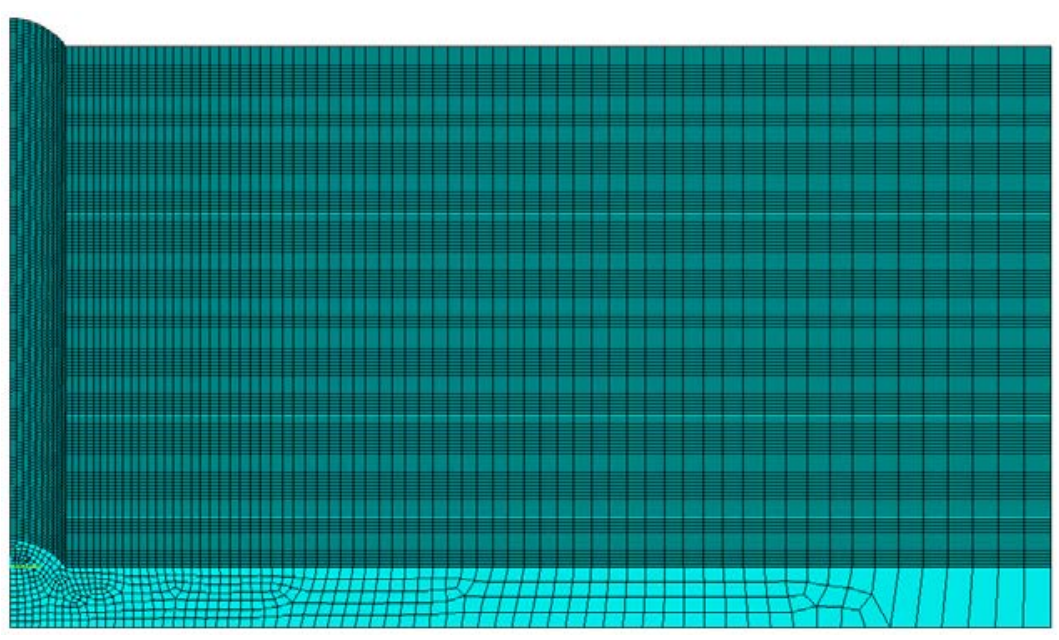

Figura 5.3: Exemplo da chapa, considerando a condição de simetria proposta. 


\section{2}

\section{Condições de Contorno}

É adotado uma condição adiabática para o plano de simetria, enquanto que as condições de contorno de convecção e radiação são empregadas em todas as outras faces livres da chapa (FIG. 5.4). Foi considerada uma temperatura inicial de $28^{\circ} \mathrm{C}$ para as chapas e para o meio externo em todas as simulações. O coeficiente de convecção $h$, adotado nos modelos para as superfícies livres das chapas foi de $20\left(\mathrm{~W} / \mathrm{m}^{2} \mathrm{~K}\right)$. Como as chapas estavam sob 3 apoios simples (para uma condição de equilíbrio estático), foi considerado o mesmo coeficiente de convecção para o inferior da chapa, como em todas as outras superfícies livres.

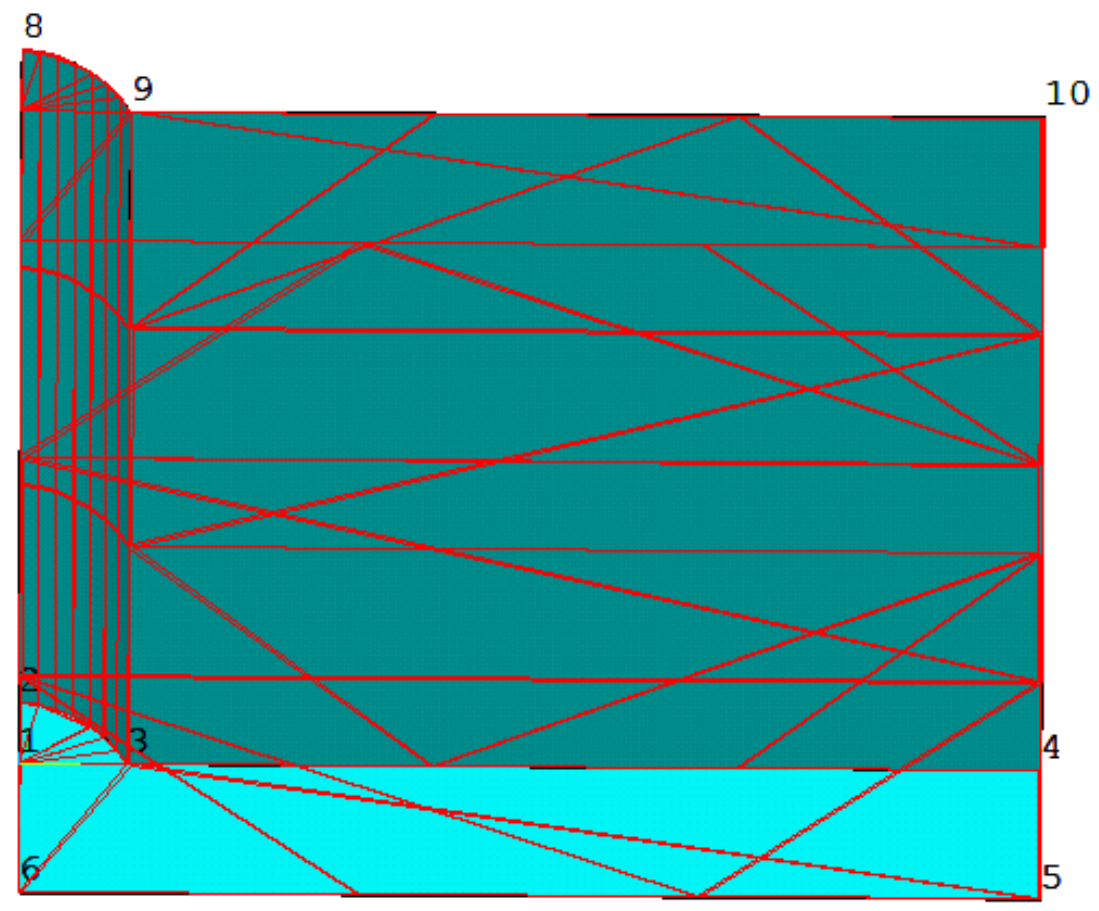

Figura 5.4: Condições de contorno convectivas no modelo axissimétrico.

Foi realizada uma análise de convergência ajustando-se a malha de elementos finitos, que possui diferentes tamanhos para a região da zona fundida e para o metal de base, afim de contemplar adequadamente os maiores gradientes térmicos presentes nesta região. A FIG. 5.5 apresenta uma visão lateral da semi chapa utilizada na simulação numérica com a malha ajustada para as diferentes regiões, assim como uma visão aumentada é exibida na FIG. 5.6. A medida que a 
distância aumenta em relação à região de maiores gradientes, os elementos aumentam de tamanho por não

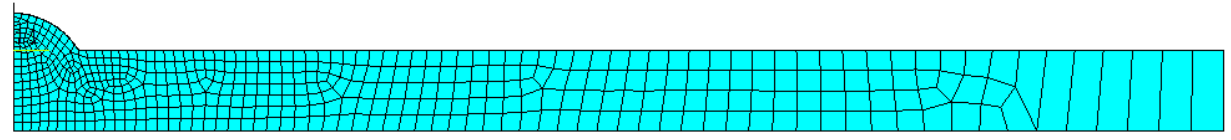

Figura 5.5: Visão lateral da malha utilizada no modelo axissimétrico.

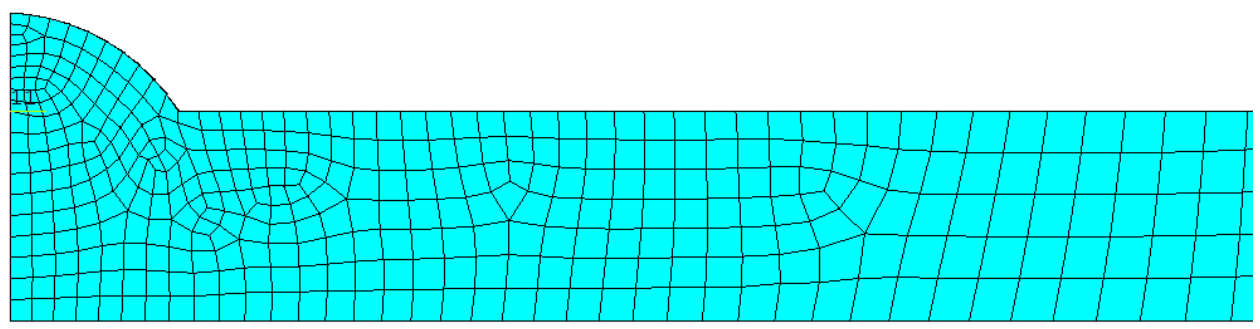

Figura 5.6: Ampliação da visão lateral da malha utilizada no modelo axissimétrico.

Na região do metal de solda, existe a mínima garantia de sempre haver uma quantidade de elementos igual ou superior a 10, na direção da meia largura do cordão. Esta regra também se aplica para a região da espessura do material.

\section{3}

\section{Modelo do Cordão de Solda}

Se qualquer material for adicionado a um sistema, alguns elementos do modelo de elementos finitos podem se tornar existentes ou inexistentes. Para essa finalidade, é possível usar a técnica "birthanddeath" nos elementos para desativar ou reativar esses próprios elementos finitos na simulação. Neste trabalho, para simular a deposição do cordão de solda do processo de soldagem MIG, essa técnica foi utilizada (CAPRICCIOLI, 2009). Esses elementos são coletados em grupos, de acordo com o movimento da fonte de calor, e o passo de tempo utilizado. Sendo assim, com o objetivo de alcançar o efeito de "morte do elemento" (ou desativação do elemento finito), o procedimento numérico não remove fisicamente os elementos "mortos", em vez disso, ele os desativa multiplicando sua matriz de rigidez por um fator de redução de $1,0 \times 10^{-6}$ (MADENCI, 2005).

Em primeiro lugar, os elementos que representam o material fundido no cordão de solda são previamente selecionados e desativados. Em seguida, eles são 
reativados durante a análise térmica de acordo com a velocidade de soldagem real do processo MIG. No caso do processo de soldagem empregado, a massa e a energia dos elementos desativados não são consideradas.

Além disso, a tensão do elemento também é definida como zero assim que esse elemento é representado como "morto" (desativado). Quando os elementos são ativados, a geração de entrada de calor é aplicada como carga no modelo térmico de elementos finitos e as tensões térmicas são calculadas para elementos recém-ativados com base na temperatura da etapa de carga atual e na temperatura de referência.

A geometria do cordão de solda foi assumida, para os modelos, de maneira a descrever a obtida no procedimento experimental em cada corpo do prova adotado.

\section{4}

\section{Análise Térmica}

Para todos os modelos, foi utilizado o elemento SOLID70 (ANSYS, 2015) para a discretização da geometria e cálculo dos ciclos térmicos, possuindo 8 nós e 1 grau de liberdade de temperatura por nó. Este elemento permite a condução de calor nas três dimensões e a utilização de propriedades termodependentes. Pode ser utilizado para análises em regime permanente ou transiente. A FIG. 5.7 mostra a geometria deste elemento, que também pode assumir os formatos prismático, tetragonal e piramidal. 

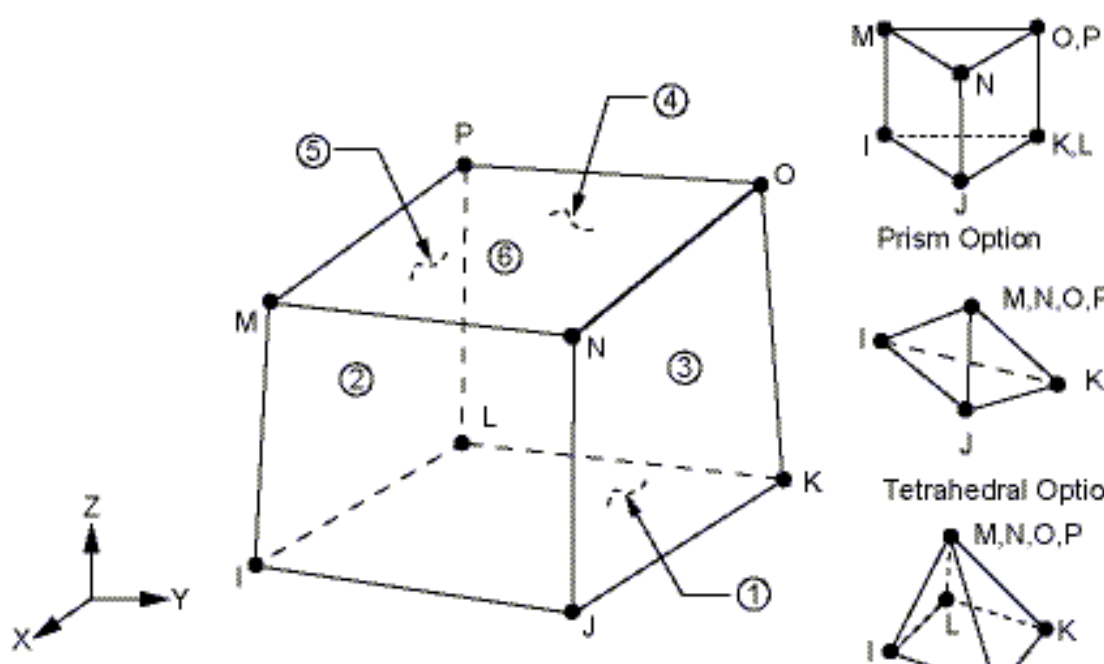

Prism Option

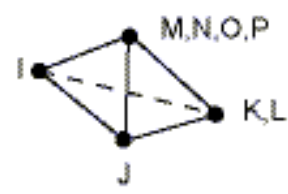

Tetrahedral Option

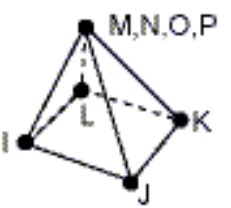

Pyramid Option

Figura 5.7: Geometria do elemento térmico SOLID70 (Ansys15).

De modo a representar a energia introduzida pelo processo de soldagem, foi utilizado o modelo de fonte de calor volumétrico de Goldak. A fonte de calor é aplicada ao modelo através do comando "BFE", onde as contribuições para a geração de calor dependem da posição espacial do elemento. A cada instante de tempo é realizado um loop e para cada elemento o centroide é recalculado. Assim as novas coordenadas do centroide recalculadas são utilizadas na equação (4.3).

A fim de realizar a comparação com os dados experimentais, foi feita a aquisição das temperaturas nos pontos geometricamente coincidentes com a alocação dos termopares, em cada modelo gerado. Os parâmetros do modelo de fonte de calor foram ajustados considerando os dados de temperatura aquisitados pelos 5 termopares acoplados nos corpos-de-prova utilizados experimentalmente. Não foi aplicado no modelo a condição de "furos", onde nos experimentos continham os termopares por não serem considerados relevantes para a análise.

Foi necessário ajustar um valor de eficiência térmica do processo de soldagem para poder calcular o calor introduzido nas chapas. A maioria dos autores trazem como referência valores para a eficiência do processo de soldagem GMAW entre 80 e 90\% (ASM, 1993; DUPONT, 1995; SAQUIB, 2012). AWS (1998) propõe uma faixa de valores entre 66 e 85\%, já Kou (2003) utiliza a faixa entre 75 e 88\%. Para os modelos empregados neste trabalho, utilizou-se a 
eficiência de $80 \%$, sendo o valor que melhor se ajustou às curvas de ciclos térmicos, mostradas no capítulo 7.

\section{5}

\section{Propriedades Físicas Utilizadas nos Modelos Numéricos}

Durante o processo de soldagem, altas temperaturas são atingidas na região da poça de fusão e grandes gradientes térmicos são gerados entre a região da solda e as regiões afastadas, as quais permanecem a uma temperatura próxima da ambiente. Os primeiros modelos analíticos para análise térmica do problema da soldagem consideravam as propriedades físicas dos materiais constantes, o que de fato não acontece em um processo real.

A utilização de modelos numéricos de simulação computacional na análise dos processos de soldagem oferece a possibilidade de incorporar, com relativa facilidade, a dependência das propriedades dos materiais com a temperatura. É importante ressaltar, no entanto, que embora os códigos de elementos finitos atuais permitam essa consideração, a informação disponível sobre o comportamento dos metais a altas temperaturas é bastante escassa e de difícil obtenção.

$\mathrm{Na}$ análise térmica transiente da soldagem, as principais propriedades físicas do material que devem ser consideradas são: a condutividade térmica, o calor específico e a massa específica. ZHU e CHAO (2002) analisaram os efeitos da dependência das propriedades em uma simulação do processo de soldagem. Seus resultados sugerem que a dependência da temperatura na condutividade térmica tem efeito na distribuição do campo de temperatura transitória durante a soldagem. Sendo assim é a que apresenta os efeitos relevantes em comparação com as demais propriedades, as quais podem ser avaliadas à temperatura ambiente, embora citem que o uso dos valores médios sobre o histórico de temperatura seja melhor

Para este trabalho, considera-se a massa específica do material como sendo constante, $7800 \mathrm{~kg} / \mathrm{m}^{3}$ (Sandvik, 2015), sendo a condutibilidade térmica e calor específico dependentes da temperatura. 
Xiaojun (2004) apresenta a variação das as propriedades térmicas do aço inoxidável duplex SAF2205 (Fig. 5.8) com a temperatura, obtidos de maneira experimental (YIMING GANG, 1992).

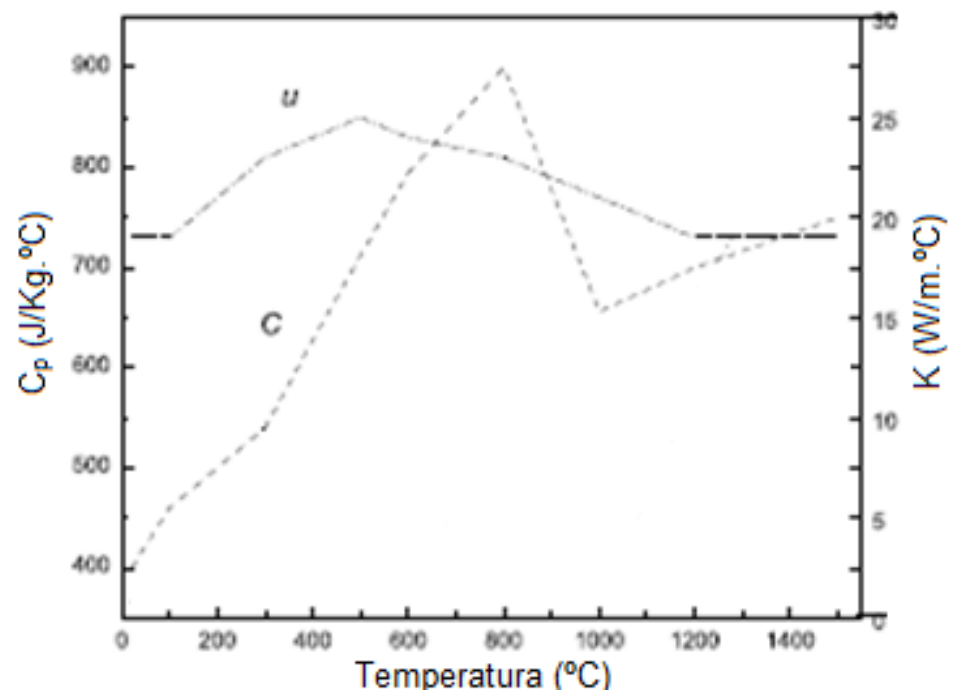

Figura 5.8: Propriedades térmicas do aço duplex SAF2205 (Xiaojun, 2004), onde a variável "K" representa a condutibilidade térmica e " $\mathrm{C}_{\mathrm{p}}$ " o calor específico do material. (Adaptado)

Alguns autores, como Almeida e colaboradores (ALMEIDA, 2016), utilizaram funções lineares (TAB. 5.2) para descrever as propriedades físicas do material, neste caso SAF 2205, não relatando qual a faixa de temperatura empregada para as funções.

Tabela 5.2: Propriedades termo físicas do aço SAF 2205 apresentadas por (ALMEIDA, 2016).

\begin{tabular}{|c|c|}
\hline Condutividade térmica em função da temperatura $\left(\mathrm{W} / \mathrm{m}^{\circ} \mathrm{C}\right):$ & $14+0,0145 \mathrm{~T}$ \\
\hline Calor específico em função da temperatura $\left(\mathrm{J} / \mathrm{kg} .{ }^{\circ} \mathrm{C}\right):$ & $473.47+0,2897 \mathrm{~T}$ \\
\hline
\end{tabular}

Estas funções lineares foram obtidas através de dados recebidos do fabricante (Sandvik), onde a amplitude de temperatura fornecida para estas propriedades é baixa (até $400^{\circ} \mathrm{C}$ ), agudamente distantes daquelas necessárias para aplicabilidade adequada em processos de soldagem. O maior problema da utilização das propriedades dessa maneira não recai sobre o formato geométrico da distribuição dos parâmetros físicos e sim sobre o comportamento assintótico ou não do material. Retratar propriedades dessa maneira, como comportamento 
linear, não descreve quaisquer fenômenos físicos que estejam ocorrendo no material e que devam ser considerados.

De maneira semelhante, Xavier e colaboradores (XAVIER, 2013) levam em consideração as propriedades do aço duplex SAF2205 como sendo linearmente dependentes da temperatura. Mostrando através de gráficos (FIG. 5.9) quais foram os valores e as faixas de temperatura adotados no emprego das mesmas.
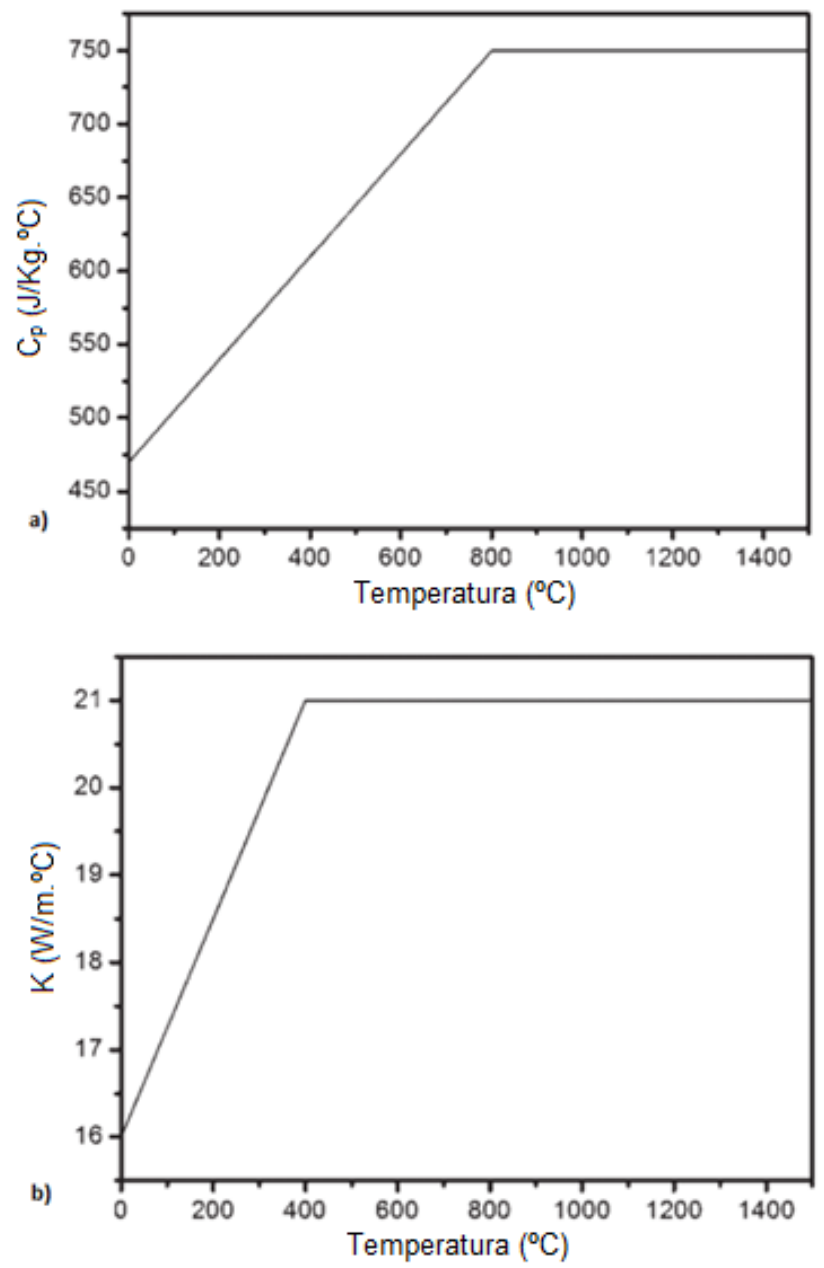

Figura 5.9: Propriedades linearmente dependentes com a temperatura apresentadas por (XAVIER, 2013); a) calor específico e b) condutividade térmica (adaptado).

No trabalho de (CASTRO et al, 2017), foi proposto um modelo capaz de prever o histórico térmico das peças soldadas, juntamente com as propriedades mecânicas desenvolvidas durante o processo de soldagem que combinam os efeitos da temperatura empregada e mudanças de fase durante a soldagem. Um método inverso é aplicado para ajustar os parâmetros termofísicos baseados em 
dados medidos. O modelo foi verificado pela comparação de perfis de temperatura medidos experimentalmente e previstos usando termopares situados dentro da zona afetada pelo calor.

Daha e seus colaboradores (DAHA, 2012) analisaram a evolução dos perfis de temperatura e a geometria da poça de fusão durante a soldagem entre um aço inoxidável duplex SAF2205 e um aço com baixo teor de carbono(A36), usando um modelo de transferência de calor numérico tridimensional. Os perfis de temperatura e a geometria da poça de fusão solidificada são apresentadas para três diferentes aportes térmicos de soldagem. Os autores apresentam as propriedades físicas termo dependentes na forma dos gráficos mostrados na FIG. 5.10. São funções próximas da linearidade até a temperatura de fusão do material. São relatados que os resultados da simulação foram comparados com dados experimentais obtidos de forma independente e foram obtidas boas concordâncias.

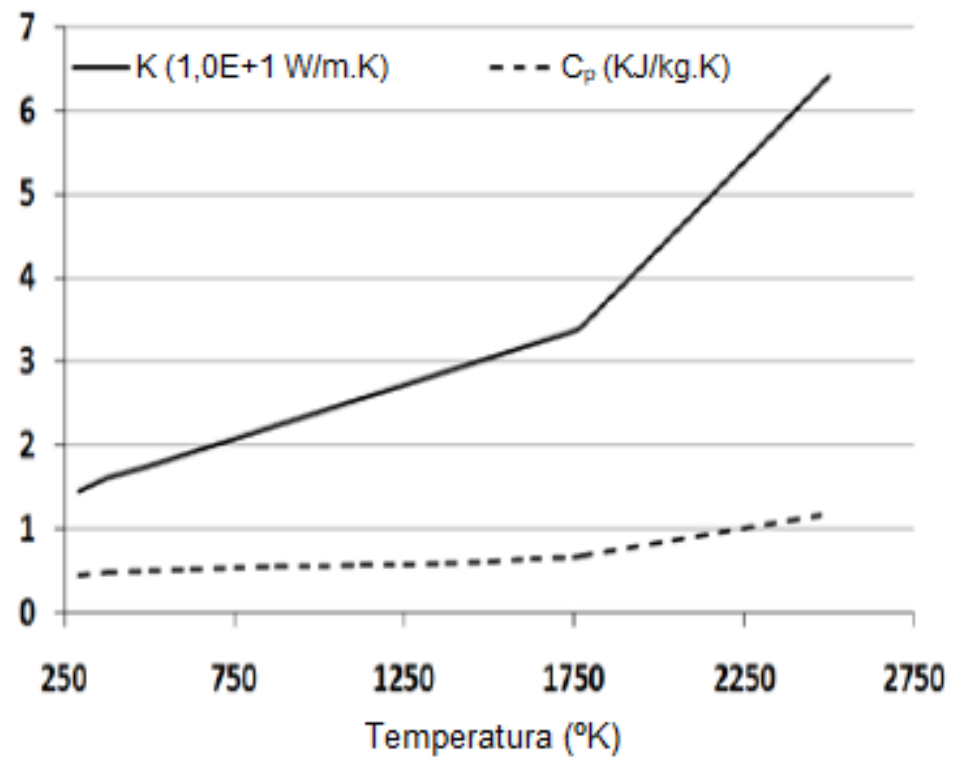

Figura 5.10: Propriedades físicas para o SAF2205 apresentadas por Daha (DAHA, 2012) (adaptado).

No trabalho de Ushio e Wu (1997) os autores apresentam as propriedades físicas termo dependentes para um aço macio (FIG. 5.11), não citando exatamente qual o aço em questão, mas com ponto de fusão e densidade iguais os dos aços inoxidáveis duplex. As propriedades encontradas pelos autores demonstram as mesmas características das exibidas por Xiaojung, onde estas exibem a mesma assintocidade e não apenas um comportamento linear crescente constante. 

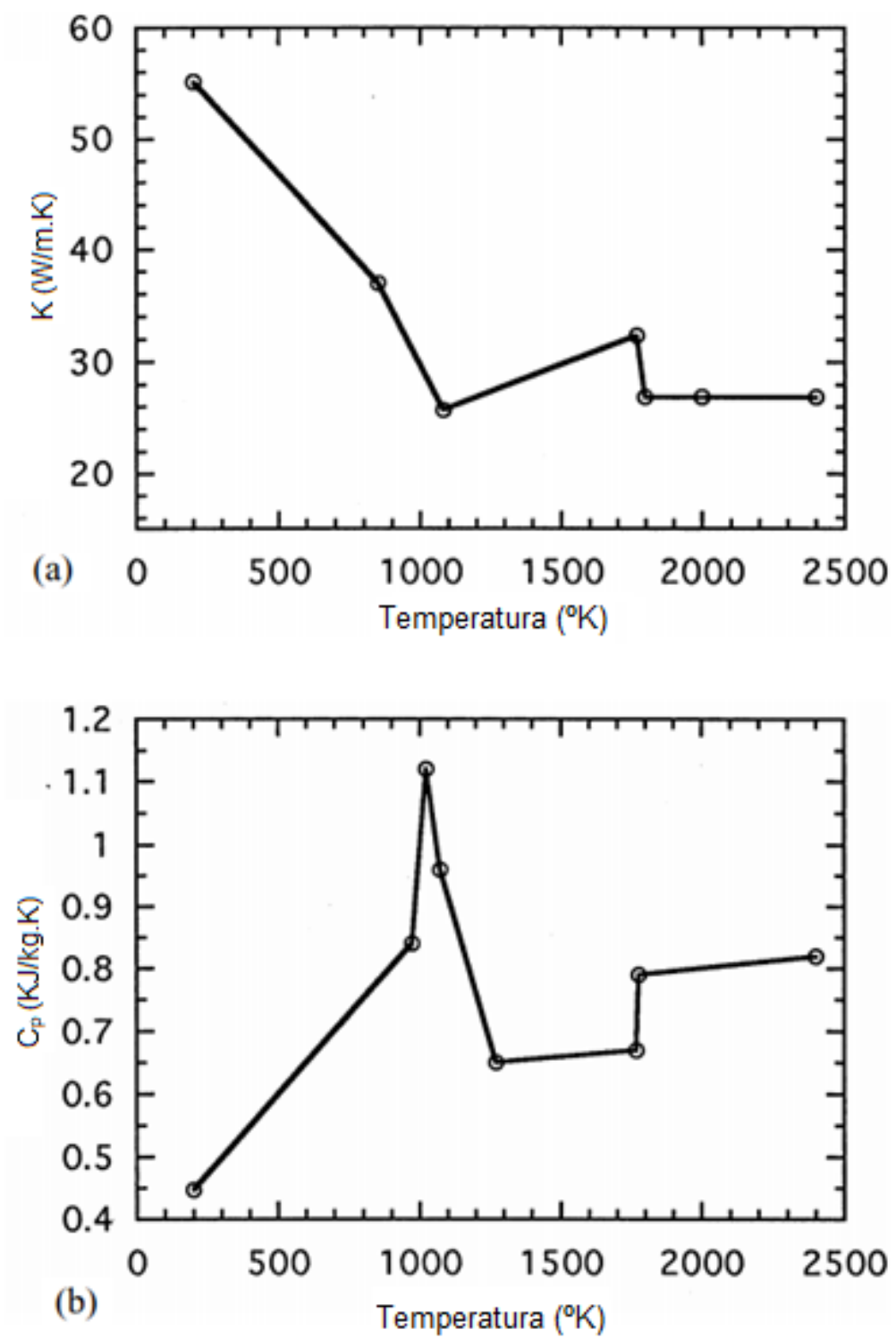

Figura 5.11: Propriedades físicas termo dependentes apresentadas por (USHIO, 1997).

Os autores Little e Kamtekar(1998) estudaram numericamente os efeitos das propriedades térmicas, especialmente a condutividade térmica nas distribuições de temperatura transitória e descobriram que as distribuições de temperatura próximas das regiões da solda são significativamente influenciadas pela escolha dos valores corretos para a condutividade térmica.

No trabalho de Zacharia com seus colaboradores (ZACHARIA, 1991), os autores realizaram um estudo de modelagem computacional para analisar a transferência de calor convectivo que ocorre durante a soldagem. A ênfase do estudo foi avaliar a sensibilidade dos resultados previstos nos efeitos da vaporização da poça de fusão e as propriedades do material prescrito. Definem 
que na capacidade de modelar o processo de soldagem com uma generalidade suficiente, é essencial que o efeito das propriedades do material sobre os resultados previstos seja entendido. Seus resultados também mostram que as escolhas das propriedades do material podem influenciar significativamente o desenvolvimento da poça de fusão. A análise mostrou que mesmo quando dados aparentemente precisos são usados, se a dependência de temperatura das propriedades físicas não for devidamente considerada, pode ocorrer discrepância significativa nas previsões dessa região. Portanto, os autores consideram que seja vital que os estudos de modelagem computacional dos processos de soldagem considerem, da melhor maneira possível, a dependência de temperatura das propriedades do material.

Assim como Zacharia, agora Mundra e seus colaboradores (MUNDRA, 1992) determinaram os efeitos de várias propriedades termo físicas dos materiais, e seus resultados indicaram que a difusividade térmica é um parâmetro fundamental e bastante relevante a ser considerado. Assim, os valores dependentes da temperatura da difusividade térmica do material empregado são cruciais para a simulação realista do comportamento da poça de fusão e da região circundante à solda. $\mathrm{O}$ autor ainda enfatiza a falta de dados teóricos e principalmente experimentais acerca destas e outras propriedades dos materiais.

Neste trabalho, considera-se as propriedades termo dependentes: condutibilidade térmica $K$, e calor específico $C_{p}$, descritas por Xiaojun (XIAOJUN, 2004), como mostradas na FIG. 5.12. Estas propriedades foram assim assumidas por descreverem o comportamento experimental encontrado para o aço duplex. A condutibilidade térmica é aumentada artificialmente para temperaturas acima da temperatura de fusão do material afim de simular a convecção de calor na poça de fusão (PAPAZOGLOU, 1982; GOLDAK, 1984, JIANG, 2005). As transformações de fase, não são consideradas nesses modelos empregados. 


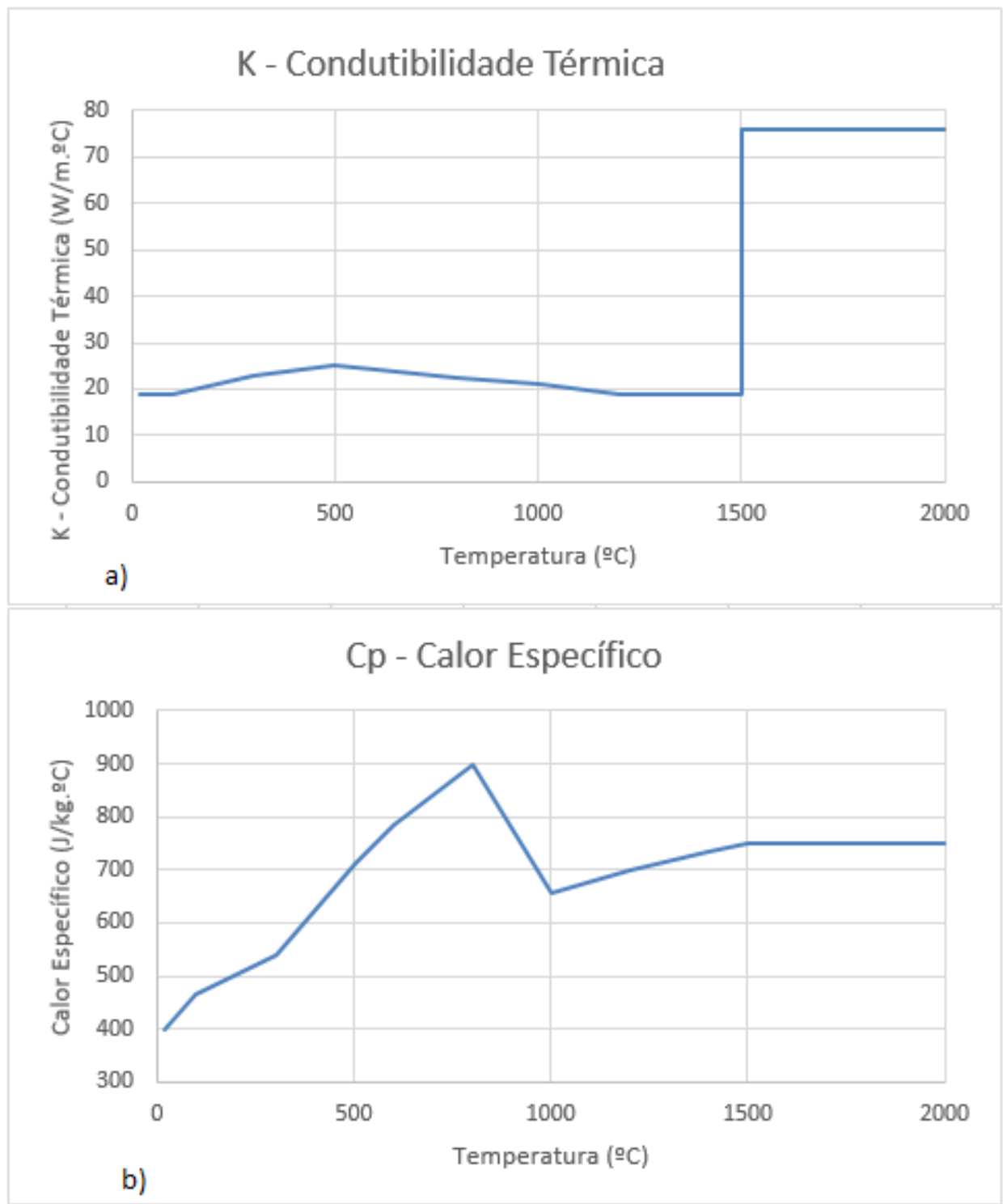

Figura 5.12: Variação das propriedades físicas, adotadas no presente trabalho, baseados nos dados apresentados por (XIAOJUN, 2004); evidenciando a) condutibilidade térmica, b) calor específico

É importante ressaltar que o trabalho desenvolvido procura estabelecer uma metodologia para modelar o comportamento dos ciclos térmicos criados no processo de soldagem abordado, adotando uma abordagem simplificada para a dependência das propriedades do material com a temperatura. O objetivo é avaliar a adequação da metodologia proposta. Estudos mais precisos podem ser posteriormente desenvolvidos utilizando-se procedimentos experimentais envolvendo a determinação das propriedades do material para uma faixa completa de temperatura. 


\section{6 \\ Materiais e Métodos Experimentais}

6.1

Materiais Utilizados

A seguir serão apresentados os materiais utilizados para a execução da etapa experimental da presente tese.

\subsection{1}

\section{Metal Base}

No presente trabalho os ensaios para obtenção dos ciclos térmicos foram desenvolvidos com chapas planas de aço duplex designação UNS31803 SAF 2205 e UNS32304 SAF 2304. A Tabela 6.1 apresenta a composição química nominal dos materiais utilizados.

Tabela 6.1: Composição química nominal aço SAF 2205 e SAF 2304 (Sandvik, 2015).

\begin{tabular}{|c|c|c|c|c|c|c|c|c|c|c|}
\hline LIGA & UNS & C & Si & Mn & $\mathbf{P}$ & $\mathbf{S}$ & $\mathrm{Cr}$ & $\mathrm{Ni}$ & Mo & $\mathbf{N}$ \\
\hline $\begin{array}{l}\text { SAF } \\
2205\end{array}$ & $\begin{array}{c}\text { UNS } \\
31803\end{array}$ & $\leq 0,03$ & $\leq 1,0$ & $\leq 2,0$ & $\leq 0,03$ & $\leq 0,015$ & 22,5 & 5,2 & 2,7 & 0,40 \\
\hline $\begin{array}{l}\text { SAF } \\
2304\end{array}$ & $\begin{array}{c}\text { UNS } \\
32304\end{array}$ & $\leq 0,03$ & $\leq 1,0$ & $\leq 2,0$ & $\leq 0,035$ & $\leq 0,015$ & 25,5 & 5,0 & 0,3 & 0,1 \\
\hline
\end{tabular}

Quanto à geometria dos corpos de prova, duas dimensões foram utilizadas

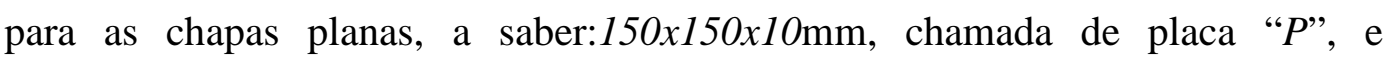
150x300x10mm, chamada de placa “G”, sendo as dimensões (comprimento $\mathrm{x}$ largura x espessura).

\section{1 .2}

\section{Consumíveis de Soldagem}

Para o processo de soldagem empregado nos experimentos foi utilizado o arame consumível, com as seguintes especificações: Sandvik Grau 22.8.3.L G7 
(AWS ER2209), de 1,2 mm de diâmetro. A composição química do arame utilizado esta apresentada na tabela 6.2abaixo:

Tabela 6.2: Composição química nominal do arame consumível 22.8.3.L G7.

\begin{tabular}{|c|c|c|c|c|c|c|c|c|c|}
\hline Arame & $\mathbf{C}$ & $\mathbf{S i}$ & $\mathbf{M n}$ & $\mathbf{P}$ & $\mathbf{S}$ & $\mathbf{C r}$ & $\mathbf{N i}$ & $\mathbf{M o}$ & $\mathbf{N}$ \\
\hline 22.8.3.L G7 & $\leq 0,02$ & 0,5 & 1,5 & $\leq 0,02$ & $\leq 0,015$ & 23 & 9 & 3.2 & 0,16 \\
\hline
\end{tabular}

\section{2}

\section{Preparação dos Corpos de Prova}

Os corpos de prova são na forma de chapas planas, nas quais foram usinados 5 furos - por chapa - com 1,5 mm de diâmetro e 4 mm de profundidade, na parte inferior da chapa, como mostrado na FIG. 6.1.

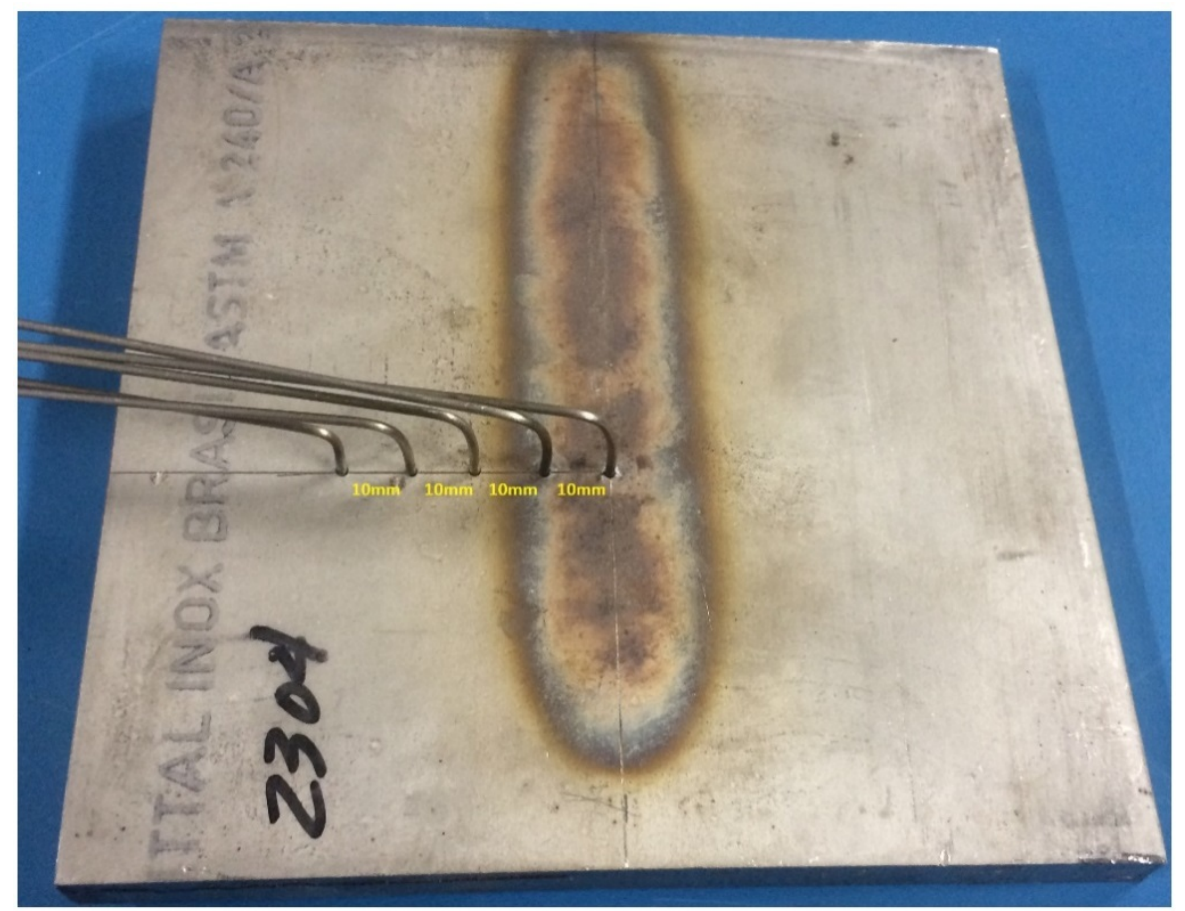

Figura 6.1: Imagem evidenciando os termopares alocados na parte inferior do corpo de prova.

Foram empregados dois aportes térmicos distintos, dentro da faixa recomendada, nos corpos de prova, afim de se avaliar o impacto destes no modelo empregado. As distâncias entre os furos e as suas posições relativas são apresentadas nas figuras abaixo (FIG. 6.2 e 6.3). O intuito seria de coletar os dados de temperatura, partindo de uma região com alto gradiente para uma de 
baixo gradiente de temperatura, onde existe um deslocamento no primeiro termopar, de 5mm com relação ao centro do cordão de solda, para o aporte térmico maior. Os termopares acoplados à chapa são do tipo "K" com bainha de aço inox, e esse deslocamento apenas do primeiro termopar para o maior aporte térmico foi pensado com o intuito de evitar a fusão do próprio termopar. O posicionamento linear dos termopares foi escolhido visando obter o perfil de temperatura ao longo da junta soldada.

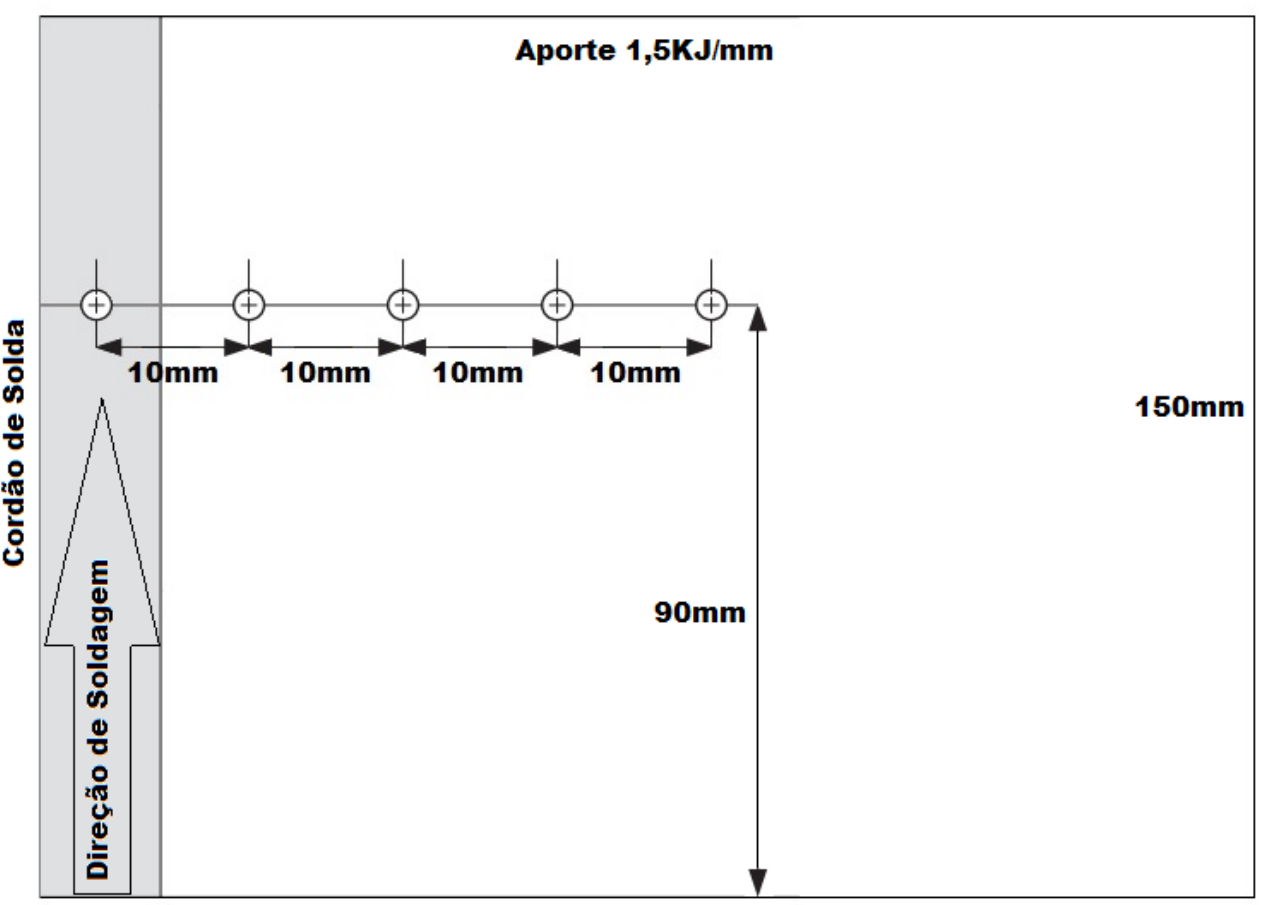

Figura 6.2: Vista inferior da chapa exibindo o esquema adotado para o posicionamento dos termopares utilizados nos corpos de prova com aportes térmicos menores. 


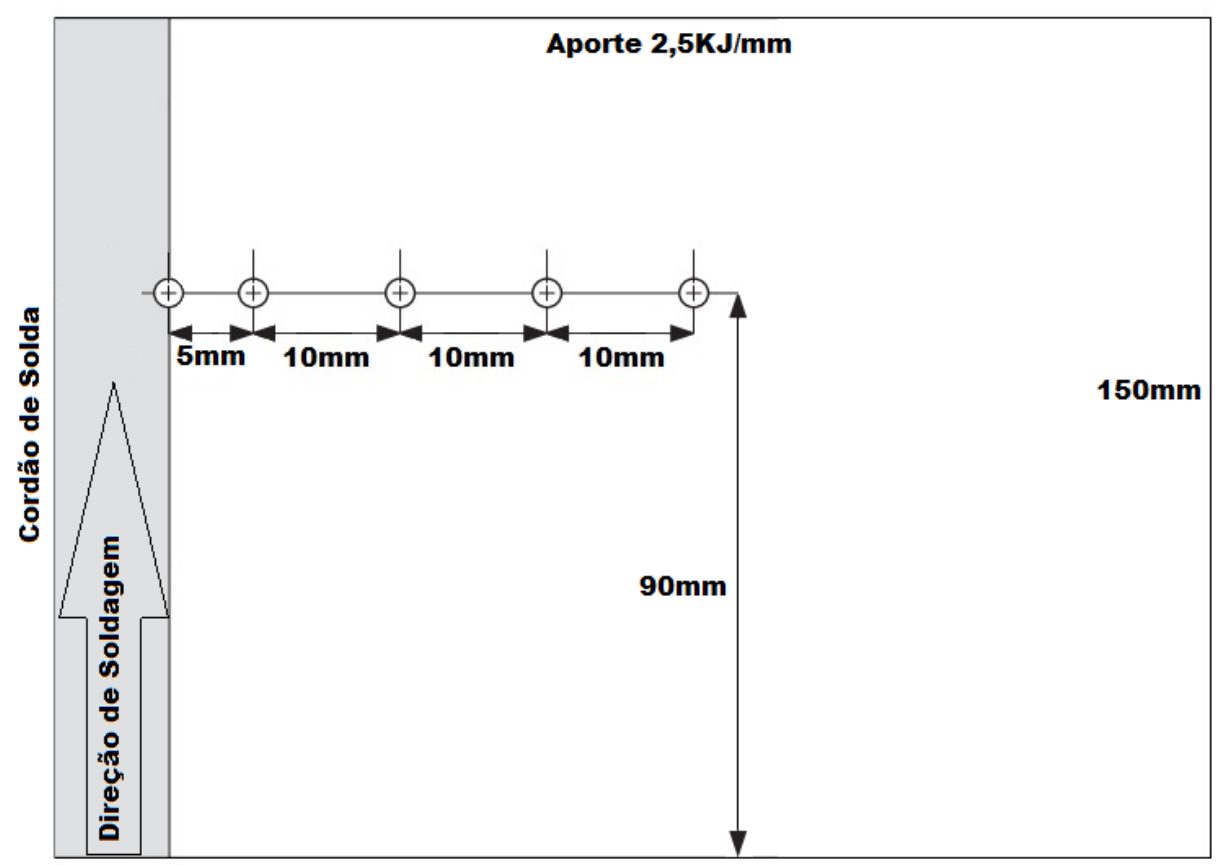

Figura 6.3: Vista inferior da chapa exibindo o esquema adotado para o posicionamento dos termopares utilizados nos corpos de prova com aportes térmicos maiores.

\section{3}

\section{Soldagem}

A soldagem de todos os corpos de prova foi do tipo cordão sobre chapa utilizando-se o processo MIG pulsado. Como gás de proteção foi utilizada uma mistura composta de $92 \% \mathrm{Ar}$ e $8 \% \mathrm{CO}_{2}$, com um fluxo de $18 \mathrm{l} / \mathrm{min}$. A fonte de energia para soldagem empregada foi o equipamento da marca Miller, modelo Millermatic 350P. Os valores de tensão e de corrente utilizados durante a soldagem de todos os corpos de prova foram obtidos diretamente do painel de instrumentos, situados na fonte de energia. $\mathrm{O}$ valor de intensidade de corrente obtido para o processo de soldagem é um valor médio uma vez que o sistema utiliza corrente pulsada.

A tabela 6.3mostra os valores dos parâmetros, para o regime de solda experimental, utilizados em cada um dos corpos de prova. Os corpos de prova estão mostrados, separados por aportes térmicos teóricos, em dois grupos, aporte maior $(2,5 \mathrm{KJ} / \mathrm{mm})$ e aporte menor $(1,5 \mathrm{KJ} / \mathrm{mm})$.A nomenclatura adotada para cada amostra é: (aço empregado) (tamanho da chapa soldada) (aporte térmico utilizado). 
Tabela 6.3: Parâmetros de soldagem utilizados nos experimentos.

\begin{tabular}{|c|c|c|c|}
\hline $\begin{array}{l}\text { APORTE } \\
\text { TÉRMICO } \\
\text { TEÓRICO }\end{array}$ & AMOSTRA & REGIME DE SOLDA & $\begin{array}{c}\text { APORTE } \\
\text { TÉRMICO } \\
\text { REAL }\end{array}$ \\
\hline \multirow{4}{*}{$1,5 \mathrm{KJ} / \mathrm{mm}$} & $\underline{2205 P 15}$ & $\begin{array}{c}\mathrm{I}_{\mathrm{s}}=184 \mathrm{~A} ; \mathrm{V}_{\mathrm{a}}=25,6 \mathrm{~V} \\
\mathrm{~V}_{\mathrm{s}}=0,0023 \mathrm{~m} / \mathrm{s}\end{array}$ & $1,63 \mathrm{KJ} / \mathrm{mm}$ \\
\hline & $\underline{205 G 15}$ & $\begin{array}{c}I_{s}=185 \mathrm{~A} ; V_{a}=25,7 \mathrm{~V} \\
V_{s}=0,0023 \mathrm{~m} / \mathrm{s}\end{array}$ & $1,65 \mathrm{KJ} / \mathrm{mm}$ \\
\hline & 2304P15 & $\begin{array}{c}I_{s}=181 \mathrm{~A} ; V_{a}=25,9 \mathrm{~V} ; \\
V_{s}=0,0023 \mathrm{~m} / \mathrm{s}\end{array}$ & $1,63 \mathrm{KJ} / \mathrm{mm}$ \\
\hline & 2304G15 & $\begin{array}{c}I_{s}=183 A ; V_{a}=26,4 \mathrm{~V} ; \\
V_{s}=0,0023 \mathrm{~m} / \mathrm{s}\end{array}$ & $1,68 \mathrm{KJ} / \mathrm{MM}$ \\
\hline \multirow{4}{*}{$2,5 \mathrm{KJ} / \mathrm{mm}$} & 2205P25 & $\begin{array}{c}\mathrm{I}_{\mathrm{s}}=186 \mathrm{~A} ; \mathrm{V}_{\mathrm{a}}=26,2 \mathrm{~V} ; \\
\mathrm{V}_{\mathrm{s}}=0,0014 \mathrm{~m} / \mathrm{s}\end{array}$ & $2,78 \mathrm{KJ} / \mathrm{mm}$ \\
\hline & $2205 G 25$ & $\begin{array}{c}I_{s}=183 A ; V_{a}=26,7 \mathrm{~V} ; \\
V_{s}=0,0014 \mathrm{~m} / \mathrm{s}\end{array}$ & $2,79 \mathrm{KJ} / \mathrm{mm}$ \\
\hline & $\underline{2304 P 25}$ & $\begin{array}{c}\mathrm{I}_{\mathrm{s}}=185 \mathrm{~A} ; \mathrm{V}_{\mathrm{a}}=26,7 \mathrm{~V} ; \\
\mathrm{V}_{\mathrm{s}}=0,0014 \mathrm{~m} / \mathrm{s}\end{array}$ & $2,82 \mathrm{KJ} / \mathrm{mm}$ \\
\hline & 2304G25 & $\begin{array}{c}\mathrm{I}_{\mathrm{s}}=189 \mathrm{~A} ; \mathrm{V}_{\mathrm{a}}=25,0 \mathrm{~V} \\
\mathrm{~V}_{\mathrm{s}}=0,0014 \mathrm{~m} / \mathrm{s}\end{array}$ & $2,7 \mathrm{KJ} / \mathrm{mm}$ \\
\hline
\end{tabular}

As figuras (6.4 - 6.5), apresentam o aspecto do cordão de solda obtido experimentalmente, com os parâmetros da tabela 6.3, para duas das oito amostras. Todas as oito amostras seguiram o mesmo padrão de aspecto do cordão relacionado à junta soldada. 


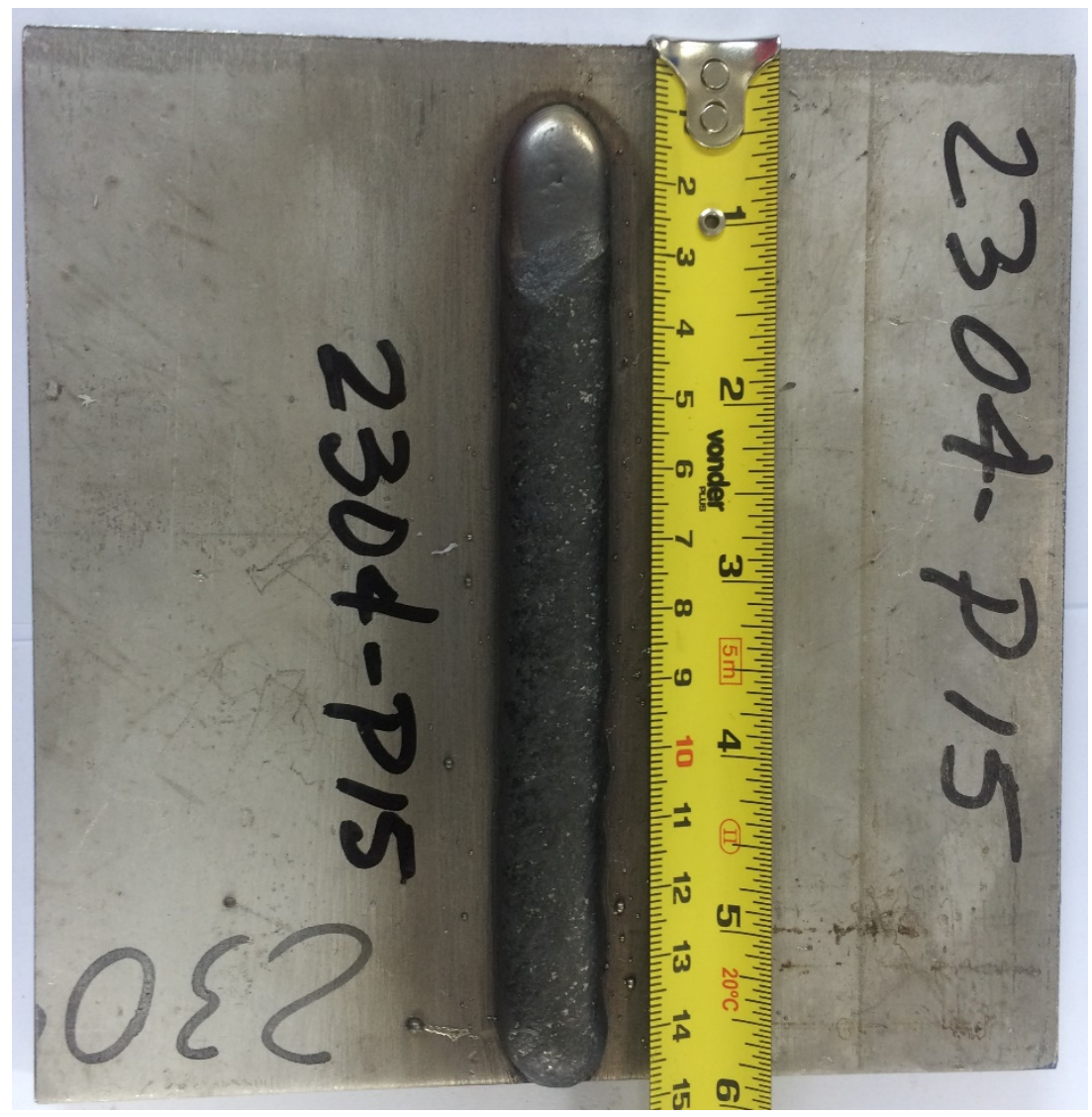

Figura 6.4: Corpo de prova 2304P15,após realização do procedimento experimental de soldagem.

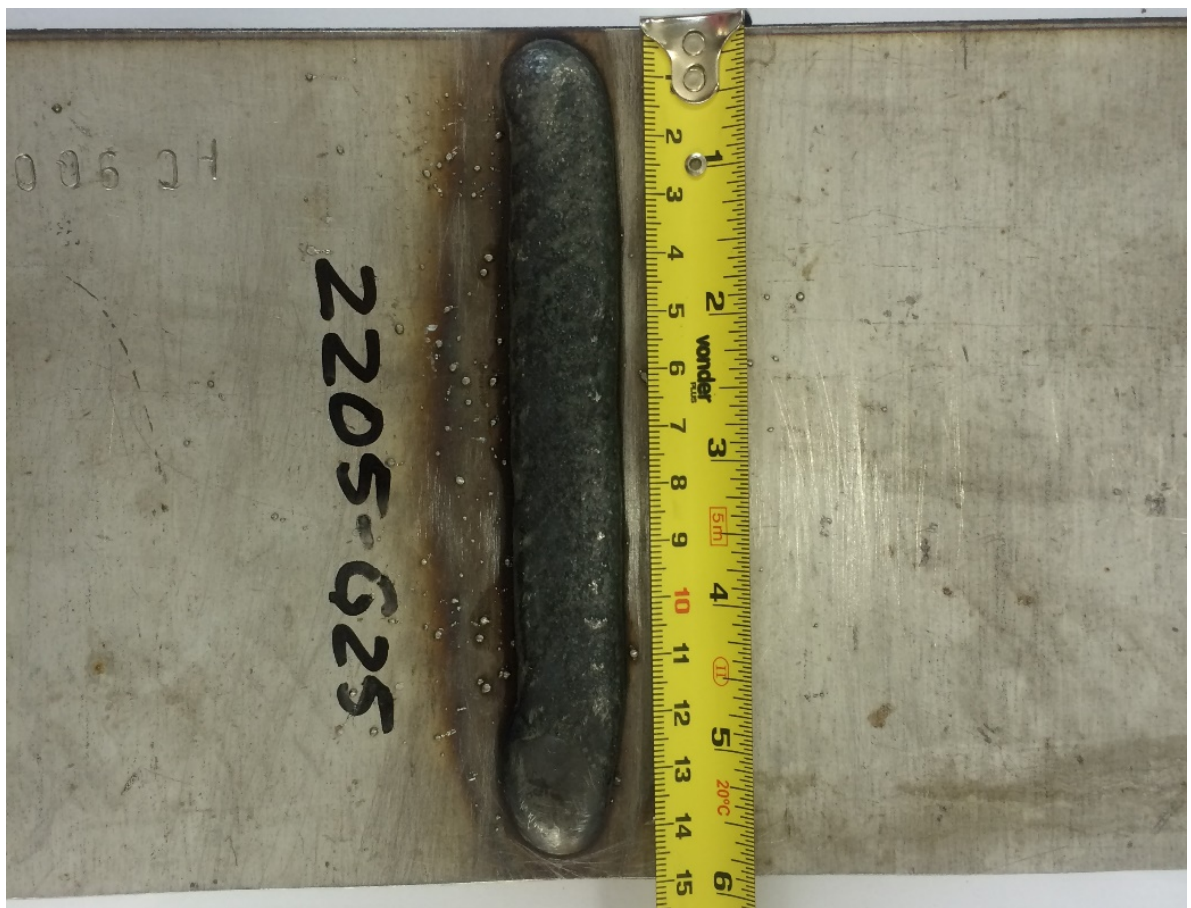

Figura 6.5: Corpo de prova 2205G25, após realização do procedimento experimental de soldagem. 


\section{4}

\section{Medição dos Ciclos Térmicos}

Para obtenção dos dados referentes às temperaturas, os termopares acoplados aos corpos de prova foram conectados a um sistema de aquisição de dados de fabricação da Hottinger Baldwin Messtechnik (HBM) modelo Spider 8,assistido pelo software Catman v.4.5. Os dados de temperatura foram registrados com uma frequência de $50 \mathrm{~Hz}$, durante um tempo total de 640 segundos, iniciado a partir do instante em que se iniciou a soldagem.

A tocha de soldagem foi montada sobre um carrinho automático (tartaruga de deslocamento), com velocidade fixa e controlada, que se deslocava paralelamente ao eixo de soldagem do corpo de prova (FIG. 6.6). A distância do bocal da solda para o corpo de prova foi mantida em $25 \mathrm{~mm}$ para todos os experimentos.

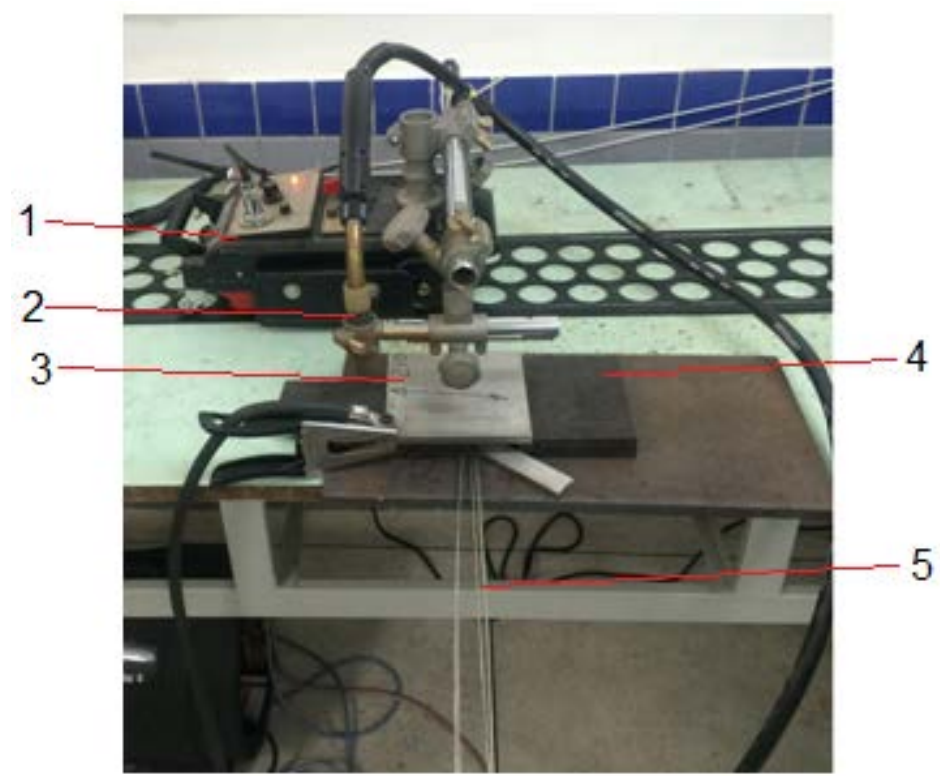

Figura 6.6: Esquema da montagem do equipamento para os ensaios experimentais. (1carro trator; 2- tocha de soldagem; 3- corpo de prova; 4- placa base; 5- termopares acoplados à chapa) 


\section{5}

\section{Análises Macrográficas da Solda}

Objetivando extrair os dados para a calibração do modelo numérico, foi realizada a análise macrográfica da seção transversal da chapa de modo a se obter as posições exatas dos termopares em relação ao cordão de solda e a extensão da ZF. As amostras receberam lixamento a úmido com uma série granulométrica partindo de 320 a 1200 e polimento manual em pasta de diamante na sequência de9, 6, 3 e $1 \mu \mathrm{m}$, tendo como lubrificante álcool 98\%.As amostras foram atacadas quimicamente, através do ataque KALLING $n^{\circ}$ 2(AGUIAR et al., 2015), que consiste em:

_100 ml de álcool;

_5gr de $\mathrm{CuCl}_{2}$ :

_100 ml de $\mathrm{HCl}$

Um tempo de imersão das amostras igual a 30 segundos foi utilizado e posterior secagem a álcool. As amostras testadas mostraram um perfil de penetração que ocasiona uma região de ZTA não uniforme e com dimensões variáveis ao longo de sua extensão. Verifica-se esse perfil devido à direção de propagação de calor ser mais eficiente na direção transversal ao cordão de solda do que em direção à parte inferior da chapa.

\subsection{1}

\section{Contagem de Fases}

As micrografias dos AIDs foram obtidas por microscopia ótica em campo claro em diferentes aumentos. Para realizar a contagem de fases, foram aquisitadas imagens de cada amostra, em escalas de cinza, com aumento de 200X, na região de interesse. Para o processamento digital e as contagens de fases das imagens foi utilizado o software Fiji. O processamento das imagens constitui na correção de iluminação, brilho / contraste e aplicação de filtros para redução de ruído e identificação dos contornos de grão. Após este procedimento a imagem passa a ser binarizada (preto e branco apenas)e por fim foram calculadas as frações de área escuras e claras, as quais correspondem respectivamente às frações volumétricas de ferrita e austenita. 


\section{Resultados e Discussão}

Neste capítulo serão apresentados os resultados dos ensaios experimentais e das simulações numéricas obtidas com os modelos pelo método de elementos finitos. Também serão apresentados resultados comparativos, utilizando o modelo numérico como referência para traçar ciclos térmicos em pontos distintos das amostras, não coincidentes com os termopares e comprovar com a devida análise experimental.

\section{1}

\section{Ensaios Experimentais}

Os ensaios experimentais envolvem a medição das temperaturas em função do tempo, por 5 termopares acoplados em cada um dos corpos de prova, além da análise metalográfica dos mesmos. Os dados obtidos são referência para calibrar os modelos numéricos adotados.

\subsection{1}

\section{Medição dos Ciclos Térmicos Através dos Termopares}

A aquisição das temperaturas foi feita através de 5 termopares acoplados a cada uma das chapas, conforme já discutido anteriormente. Os dados foram apresentados na forma de gráficos e podem ser observados adiante para cada um dos casos. Como os termopares estão dispostos de maneira linear em relação ao centro do cordão de solda, sempre existirá uma dependência das temperaturas dos termopares da seguinte maneira: Temp (TP-1) >Temp (TP-2) >Temp (TP-3) $>$ Temp (TP-4) > Temp (TP-5).

A seguir estão mostrados os ciclos térmicos para todos os corpos de prova, tomando-se apenas os valores de temperatura obtidos pelos termopares dos experimentos (FIG. 7.1 -7.8). A nomenclatura adotada para os termopares associados aos experimentos é (TP1-EXP; TP2-EXP; TP3-EXP; TP4-EXP e TP5- 
EXP) e para os pontos registrando os ciclos térmicos relacionados aos termopares no modelo numérico é (TP1-SIM; TP2-SIM; TP3-SIM; TP4-SIM e TP5-SIM).

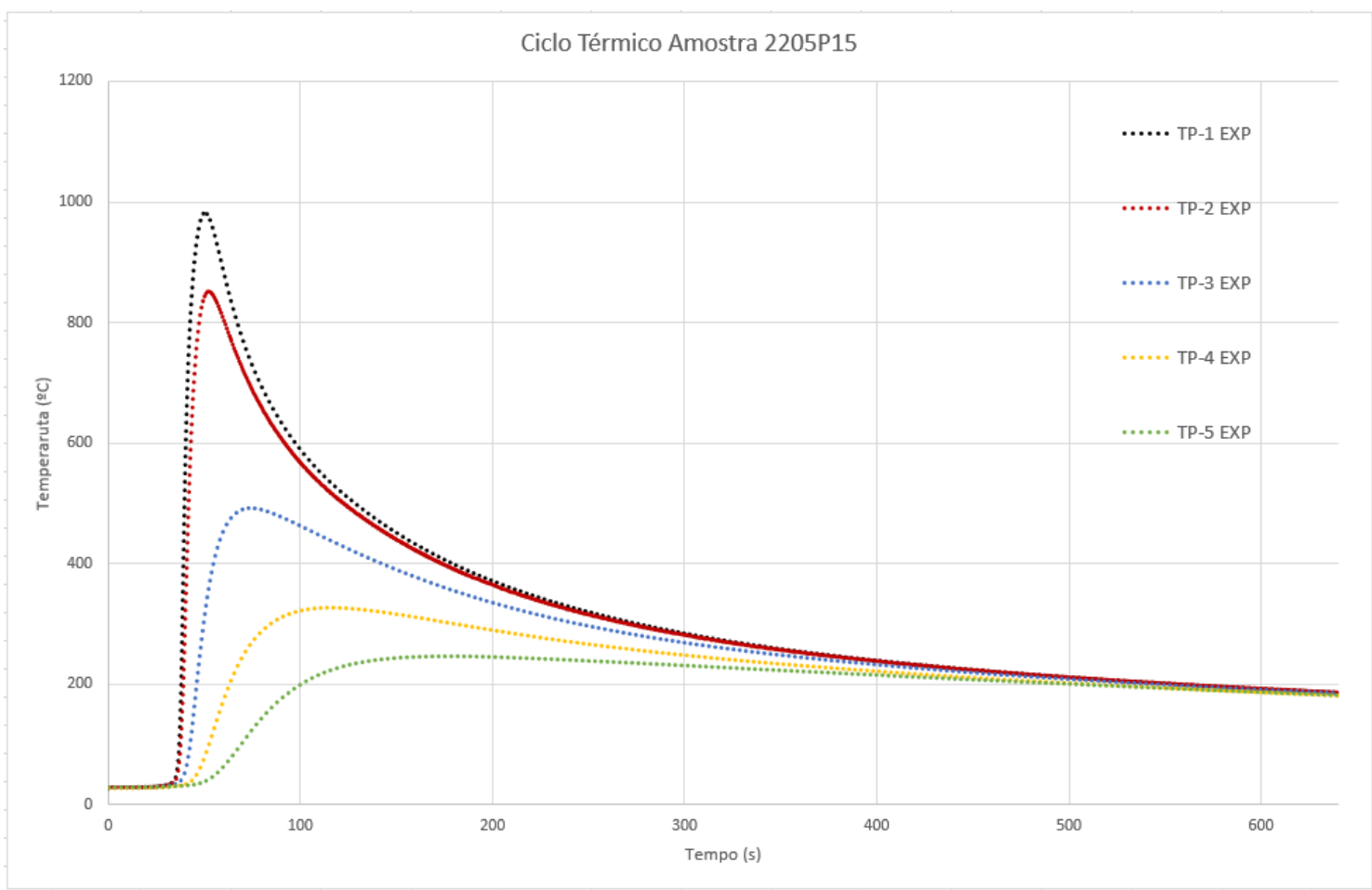

Figura 7.1: Ciclo térmico adquirido do processo experimental para a amostra 2205P15.

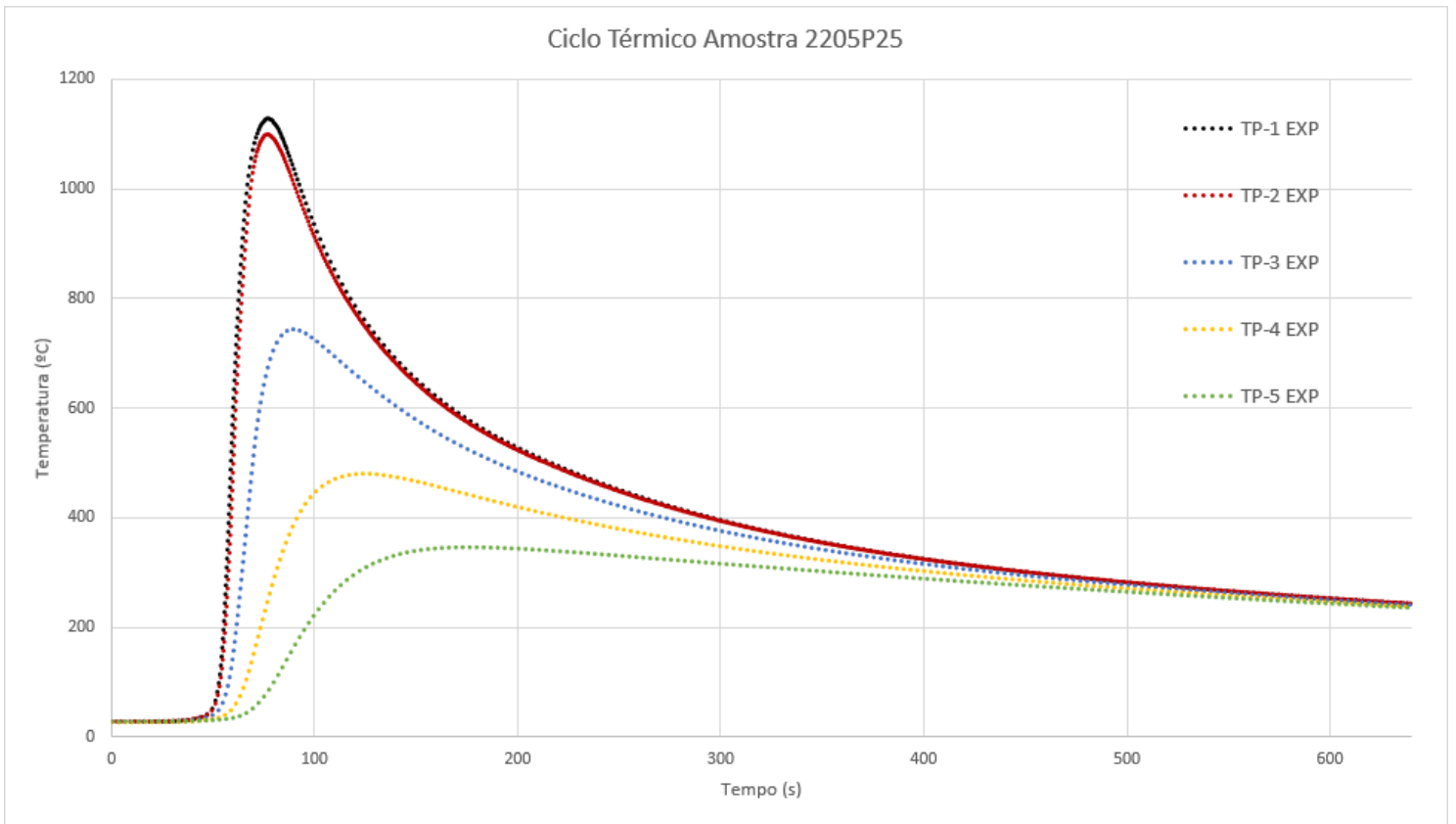

Figura 7.2: Ciclo térmico adquirido do processo experimental para a amostra 2205P25. 


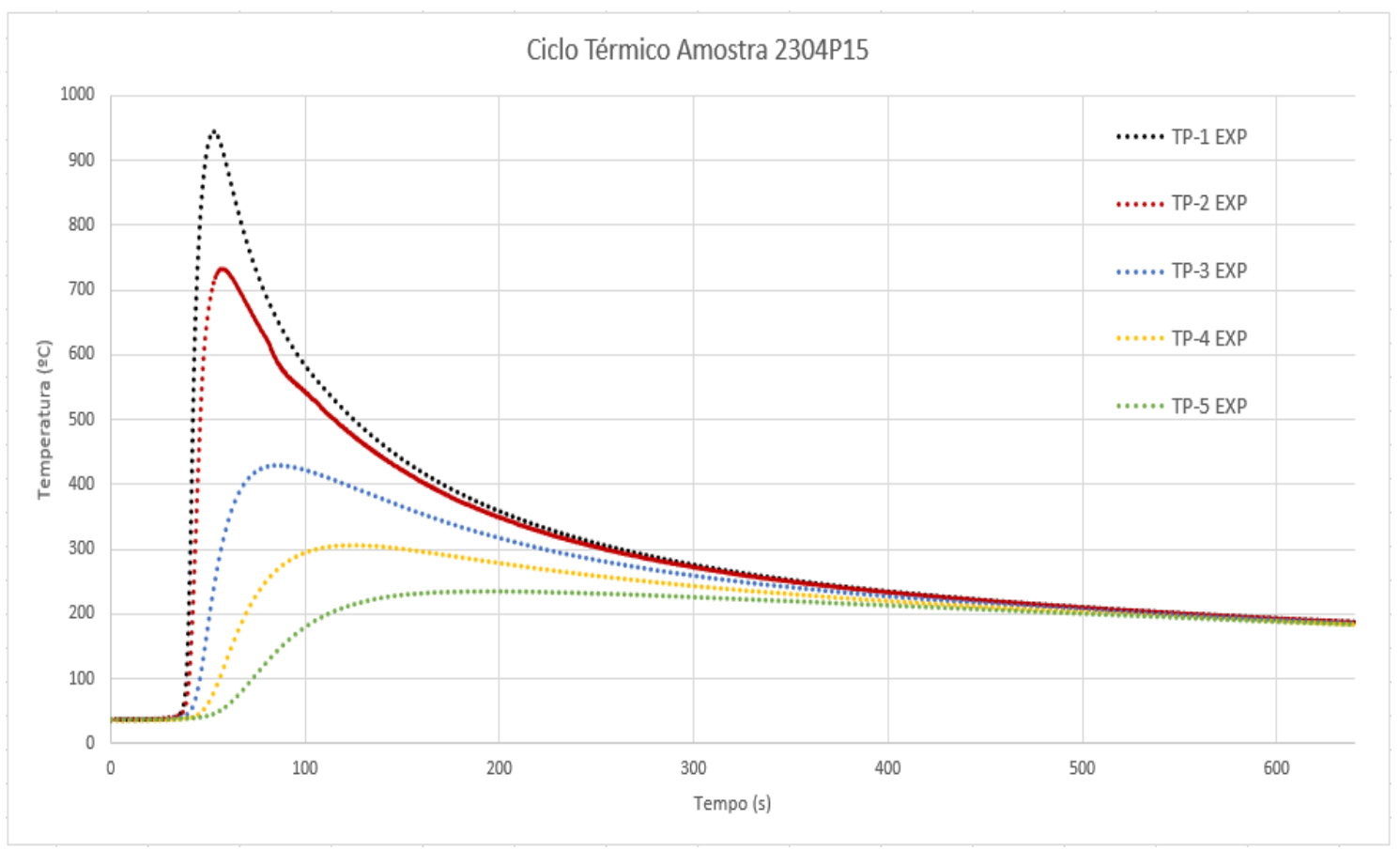

Figura 7.3: Ciclo térmico adquirido do processo experimental para a amostra 2304P15.

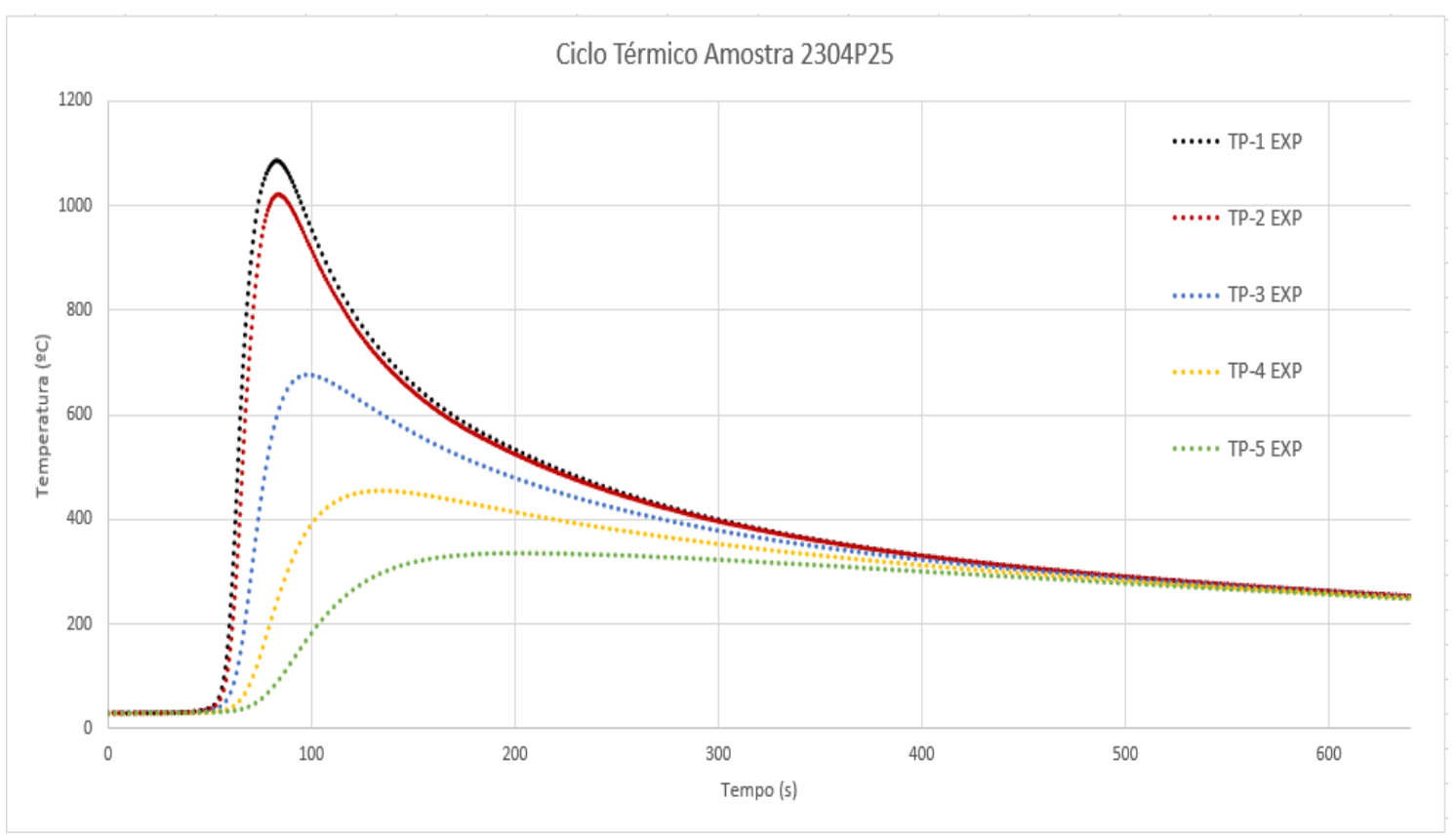

Figura 7.4: Ciclo térmico adquirido do processo experimental para a amostra 2304P25. 


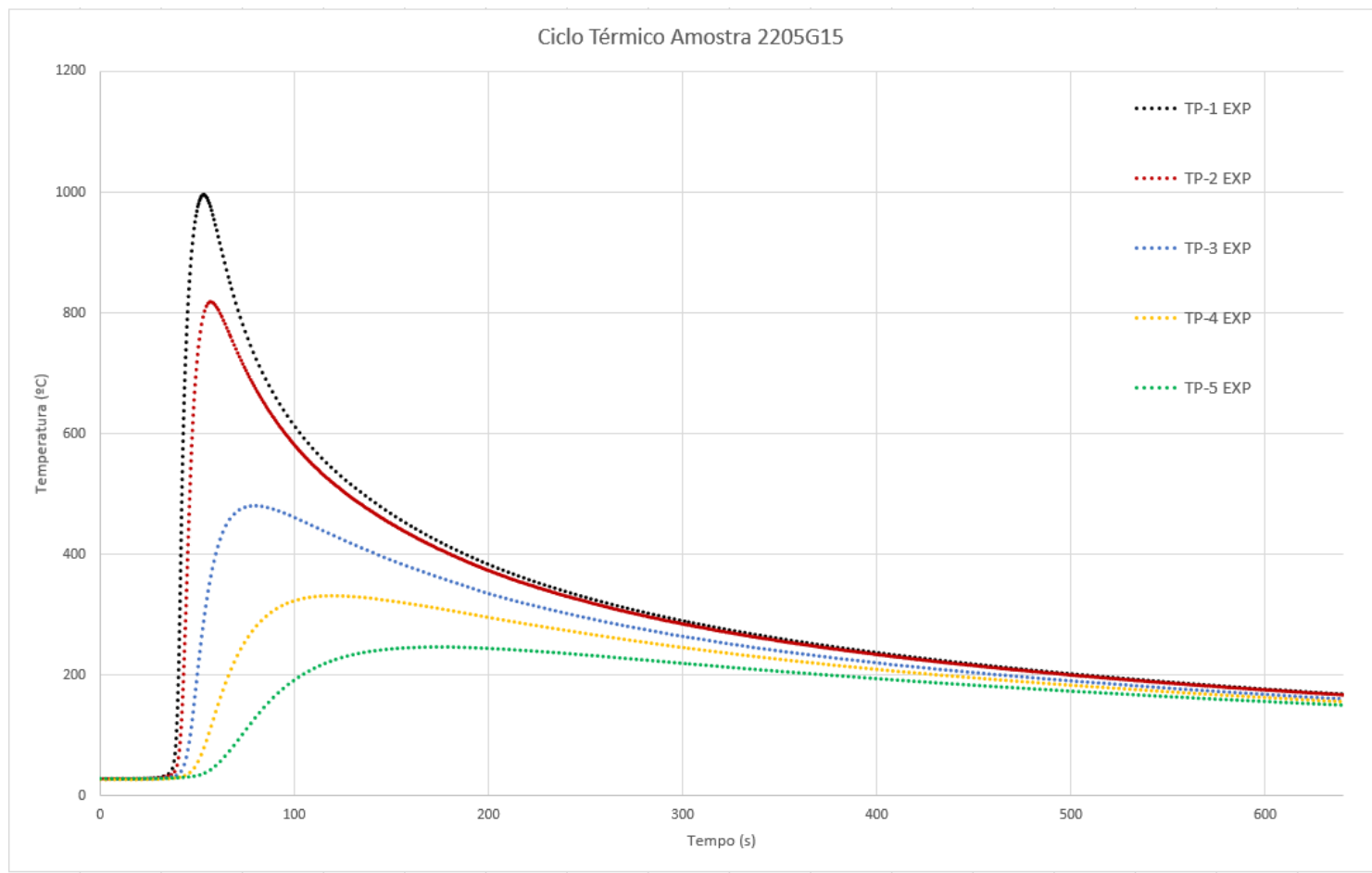

Figura 7.5: Ciclo térmico adquirido do processo experimental para a amostra $2205 \mathrm{G} 15$.

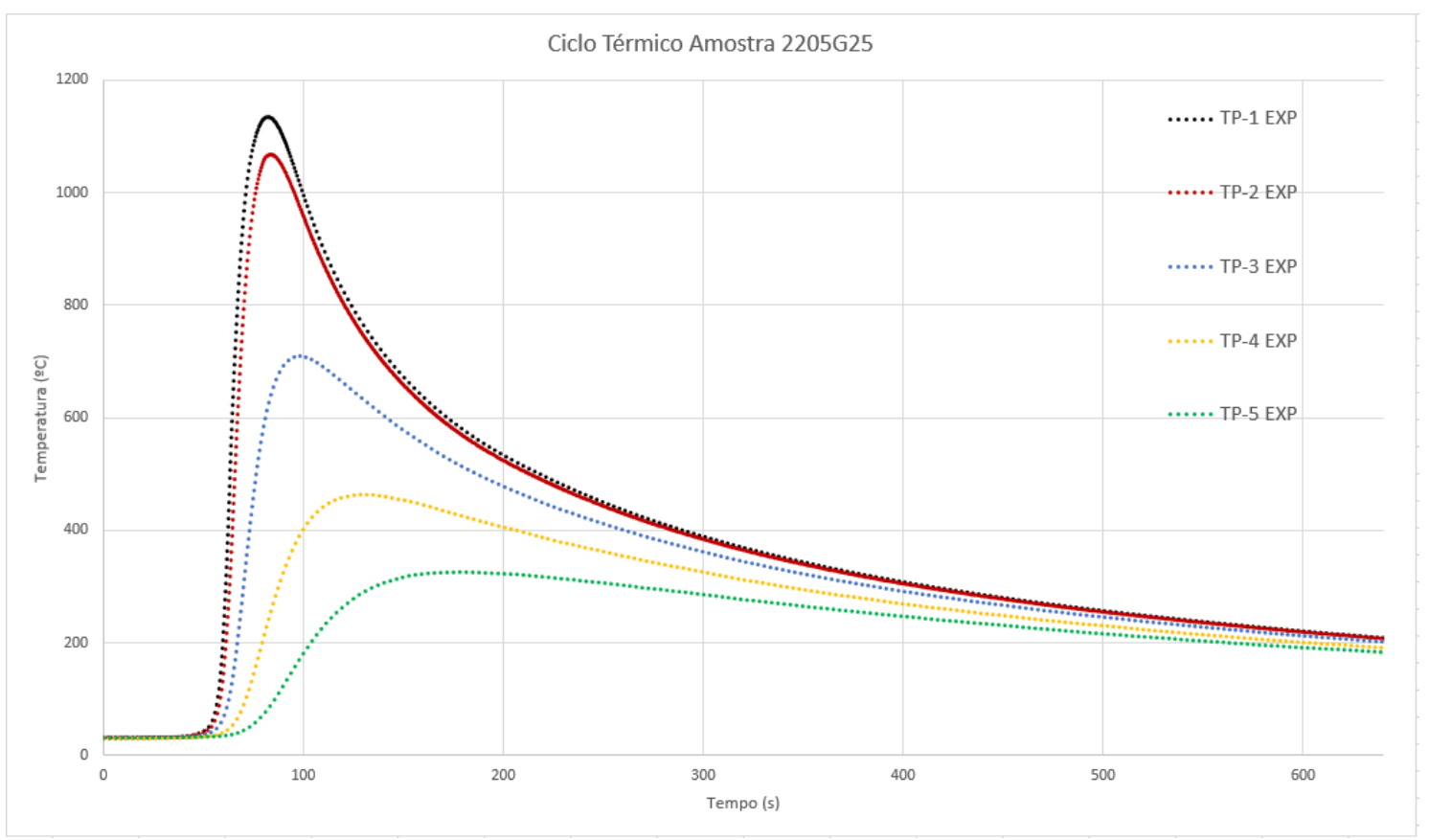

Figura 7.6: Ciclo térmico adquirido do processo experimental para a amostra 2205G25. 


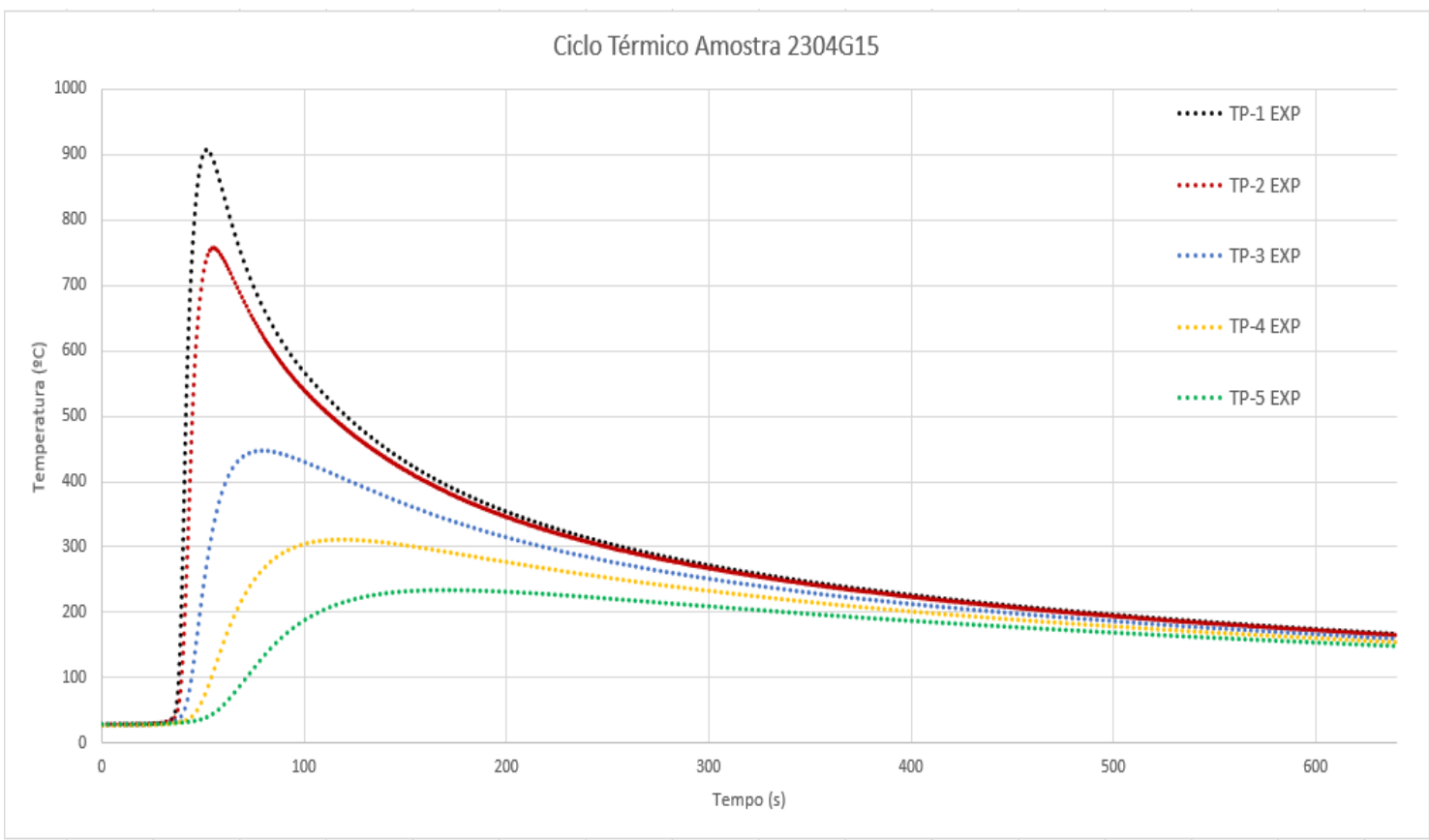

Figura 7.7: Ciclo térmico adquirido do processo experimental para a amostra 2304G15.

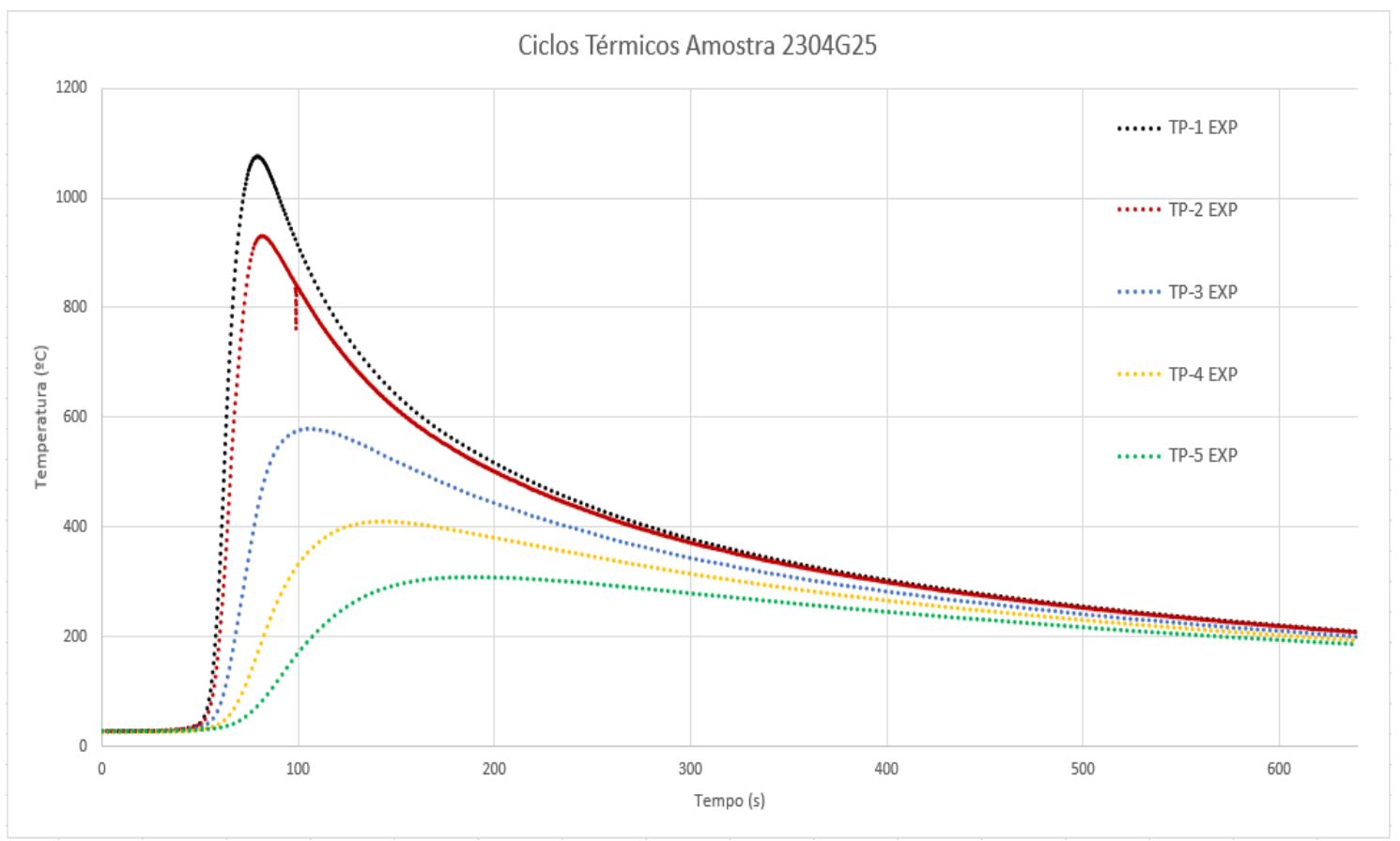

Figura 7.8: Ciclo térmico adquirido do processo experimental para a amostra $2304 \mathrm{G} 25$.

$\mathrm{Na}$ figura 7.8, nota-se a queda repentina de temperatura nos dados experimentais do termopar 2 (TP-2) que está associada à interrupção momentânea do seu adequado funcionamento, a partir de um instante de tempo próximo a 100s. Da mesma forma, uma perturbação acontece nos dados experimentais relacionados ao mesmo termopar 2, mostrado na figura 7.3. 
Pode-se notar que as características geométricas das curvas são as mesmas para os dois materiais distintos, explicitando o fato da condução térmica ser muito semelhante entre eles. Outro fato que corrobora com tal afirmação é a relação aproximada dos tempos em que cada termopar atingiu a sua temperatura de pico. E, como esperado, as temperaturas de pico para todos os termopares relacionados às amostras com maiores aportes térmicos $(2,5 \mathrm{KJ} / \mathrm{mm})$, registraram valores maiores, devido a maior quantidade de energia fornecida ao material.

$\mathrm{Na}$ comparação entre duas amostras de mesmo aporte térmico e materiais diferentes - 2205G15 e 2304G15 por exemplo - as diferenças registradas nas temperaturas de pico podem ser explicadas devido à localização exata dos termopares. Aconteceram deslocamentos, milimétricos, no momento de se perfurar as chapas, antes da alocação dos termopares, da posição esperada para a posição real encontrada, situação devidamente corrigida nos modelos numéricos. Circunstancia semelhante acontece para os termopares de um mesmo corpo de prova, onde suas posições relativas ficaram milimétricamente alteradas daquela anteriormente prevista. Como já citado no capítulo anterior, houve um deslocamento no primeiro termopar em relação ao segundo, de $5 \mathrm{~mm}$ de aproximação, para as chapas com aporte térmico de $2,5 \mathrm{KJ} / \mathrm{mm}$, com o intuito de evitar a fusão do termopar com o metal base do corpo de prova, devido às altas temperaturas encontradas na posição original.

\subsection{2}

\section{Análise Metalográfica}

Foi realizada a análise macrográfica da seção transversal ao cordão de solda para a medição das extensões da Zona Termicamente Afetada (ZTA) e da Zona Fundida (ZF). As figuras 7.9 e 7.10 apresentam macrografias realizadas nas amostras 2205G15 e 2304G25, de maneira característica a todas as outras amostras. Como pode ser observado, o perfil de penetração da linha de fusão não uniforme, ocasiona em uma ZTA com dimensões variáveis ao longo de toda sua extensão. 


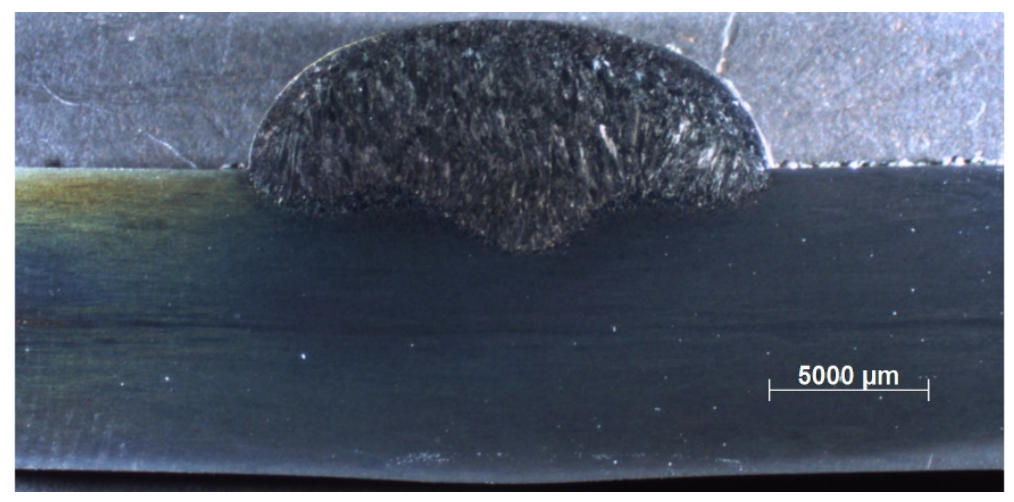

Figura 7.9: Macrografia característica realizada em um dos corpos de prova (2205G15).

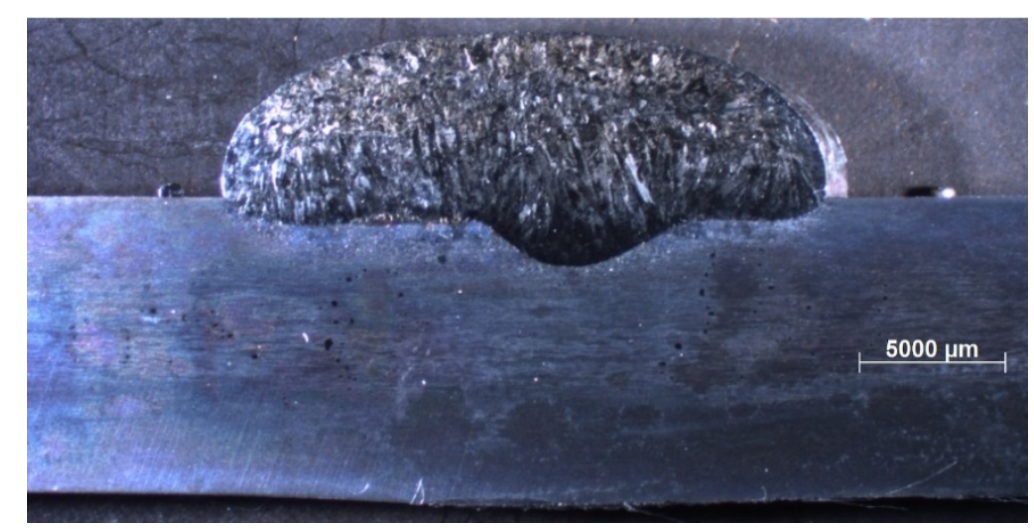

Figura 7.10: Macrografia característica realizada em um dos corpos de prova (2304G25).

A fim de permitir a comparação com os modelos numéricos propostos no presente trabalho, que não preveem esse perfil geométrico da ZTA, foi adotada uma análise da medida da penetração da linha de fusão em relação à superfície superior da chapa. A escolha, por se tratar da zona fundida, recai em dois fatores primordiais, a saber: a demarcação desta linha é clara e de fácil identificação; a temperatura associada a essa região possui uma faixa muito pequena de variação. O valor para a faixa de temperatura de fusão do metal totalmente líquido é de 1460 a $1480^{\circ} \mathrm{C}$ (ASM, 1966), sendo assumido por questão de comparação o patamar intermediário $1470^{\circ} \mathrm{C}$. A correta identificação da extensão da ZTA para as amostras soldadas se mostrou de difícil resolução, sendo simples identificar o início da mesma (logo adjacente à linha de fusão), mas a determinação do término dessa região, bastante complexa e imprecisa.

Na tabela 7.1 estão mostrados os valores relacionados à penetração da linha de fusão para cada uma das amostras obtidas, tomando como patamar o topo da chapa. 
Tabela 7.1: Profundidade medida da linha de fusão para cada amostra.

\begin{tabular}{|c|c|}
\hline Amostra & Penetração (mm) \\
\hline$\underline{2205 P 15}$ & 2,7 \\
\hline$\underline{2205 G 15}$ & 2,6 \\
\hline$\underline{2304 P 15}$ & 2,6 \\
\hline$\underline{2304 G 15}$ & 2,7 \\
\hline$\underline{2205 P 25}$ & 1,5 \\
\hline$\underline{2205 G 25}$ & 2,1 \\
\hline$\underline{2304 P 25}$ & 1,2 \\
\hline$\underline{2304 G 25}$ & 2,4 \\
\hline
\end{tabular}

Nos procedimentos experimentais, identificou-se que à medida que aumenta a energia de soldagem, aumenta a largura do cordão de solda (LONDOÑO, 2001). No entanto, deve ser levado em consideração que, neste caso, somente uma seção transversal do cordão foi preparada para análise, e que a mesma muda de um lugar no corpo de prova para outro. Portanto, nesta pesquisa não foi feito nenhum tipo de análise relacionada com o formato do cordão de solda.

\section{2}

\section{Simulações Numéricas}

As análises numéricas realizadas no presente trabalho consideram a utilização de um modelo tridimensional que somente permite apreciações térmicas. Adotou-se a leitura das temperaturas de pontos geometricamente coincidentes com os experimentais para cada corpo de prova e regime de soldagem empregado. Vale salientar que no modelo, quando um nó não é encontrado no ponto exigido de leitura da temperatura, faz uma busca espacial, adquirindo a temperatura no nó mais próximo (o que pode ser considerada uma pequena fonte de erro). 


\subsection{1}

\section{Efeito de Borda}

Quando se trata de modelagem numérica computacional, deve-se sempre visar construir o menor sistema possível que consiga, de maneira satisfatória, reproduzir o sistema real físico pretendido. Assim no princípio da modelagem, existe um problema típico chamado de "efeito de borda" que define a geometria (comprimento e largura) mínima do sistema (já abordado na seção 4.1). De posse dos ciclos térmicos adquiridos pelo conjunto de termopares acoplados aos corpos de prova, é possível identificar o impacto das duas geometrias empregadas no presente trabalho, com relação ao resultado pretendido.

Portanto, para se utilizar a estrutura de elementos finitos, é preciso definir as dimensões do sistema a fim de que estas sejam compatíveis com as condições de contorno do modelo. Uma importante condição de contorno é a retirada de calor do sistema aqui estudado, na direção transversal à direção de soldagem. Para essa análise, os parâmetros importantes são a condução e a convecção térmicas empregadas no modelo.

A função que descreve a convecção térmica de uma situação real é dependente de alguns fatores, como o meio onde a peça está imersa e a temperatura. No presente trabalho, por se tratar de um modelo simplificado, representou-se a convecção térmica através de valores discretos ao invés de funções dependentes da temperatura.

Como mostrado na tabela 7.1, adotando uma separação por aporte térmico empregado (1,5 e 2,5 KJ/mm), as amostras com menor aporte térmico apresentam uma uniformidade do perfil de penetração da região que sofreu fusão entre elas. Da mesma forma, houve um comportamento experimental uniforme para ambas as 4 amostras, no que se refere a altura e largura do cordão de solda.

Já para as 4 amostras relacionadas ao maior aporte térmico empregado, notou-se uma maior diferença entre alguns aspectos, entre eles as características físicas do cordão de solda. Mas para este caso, a maior diferença foi no que diz respeito à penetração da região fundida, sendo bastante distinta entre as amostras, mas agrupadas de 2 em 2. Aquelas que possuem a maior geometria de 150x300mm (2205G25 e 2304G25), obtiveram uma maior penetração de calor no material. Já as outras duas amostras, com as menores geometrias para esse mesmo 
aporte térmico (2205P25 e 2304P25) apresentaram um perfil de penetração da linha de fusão distintamente menor, o que pode ser um indicativo do efeito de borda nas amostras.

Com o intuito de analisar os efeitos das bordas na evolução da temperatura dos corpos de prova, foram feitas simulações das amostras com as menores dimensões geométricas (150x150mm) para avaliar o perfil de temperatura na região da borda, ou seja, a $75 \mathrm{~mm}$ do centro do cordão (como já discutido anteriormente, o modelo adota uma condição de simetria na chapa), paralelamente ao mesmo.

Obtidas as informações sobre o perfil de temperaturas na borda transversal à direção de soldagem, para a amostra com geometria de 150x150mm, foi então duplicada a extensão dessa dimensão lateral, tornando a geometria da amostra 150x300mm. Assim o procedimento de análise do perfil de temperatura na borda foi repetido, naturalmente que se mantendo todos os outros parâmetros adotados iguais aos do procedimento anterior. A distância de análise do perfil de temperatura também foi mantida a mesma da anterior, ou seja, a $75 \mathrm{~mm}$ do centro do cordão de solda. Novamente a dimensão lateral da chapa a ser simulada foi duplicada, tornando-a 150x600mm e o procedimento de análise do perfil de temperatura se deu da mesma forma.

Os resultados obtidos são apresentados em três tempos distintos, a saber: o tempo de 108s, é o tempo relacionado com o término da soldagem; 448s é um tempo intermediário, já no processo de resfriamento da amostra; e 638s é o tempo final da análise numérica.

Analisando inicialmente a amostra 2205P25, as figuras $7.11-7.13$ mostram o perfil de temperatura nos 3 tempos adotados, comparando em cada tempo os 3 tamanhos de geometria para a chapa soldada com as mesmas condições de soldagem. Recordando apenas, que este corpo de prova experimental apresenta um tamanho de 150x150mm, as outras duas situações geométricas são apenas extrapolações numéricas a fim de investigar tal efeito sob a amostra. 


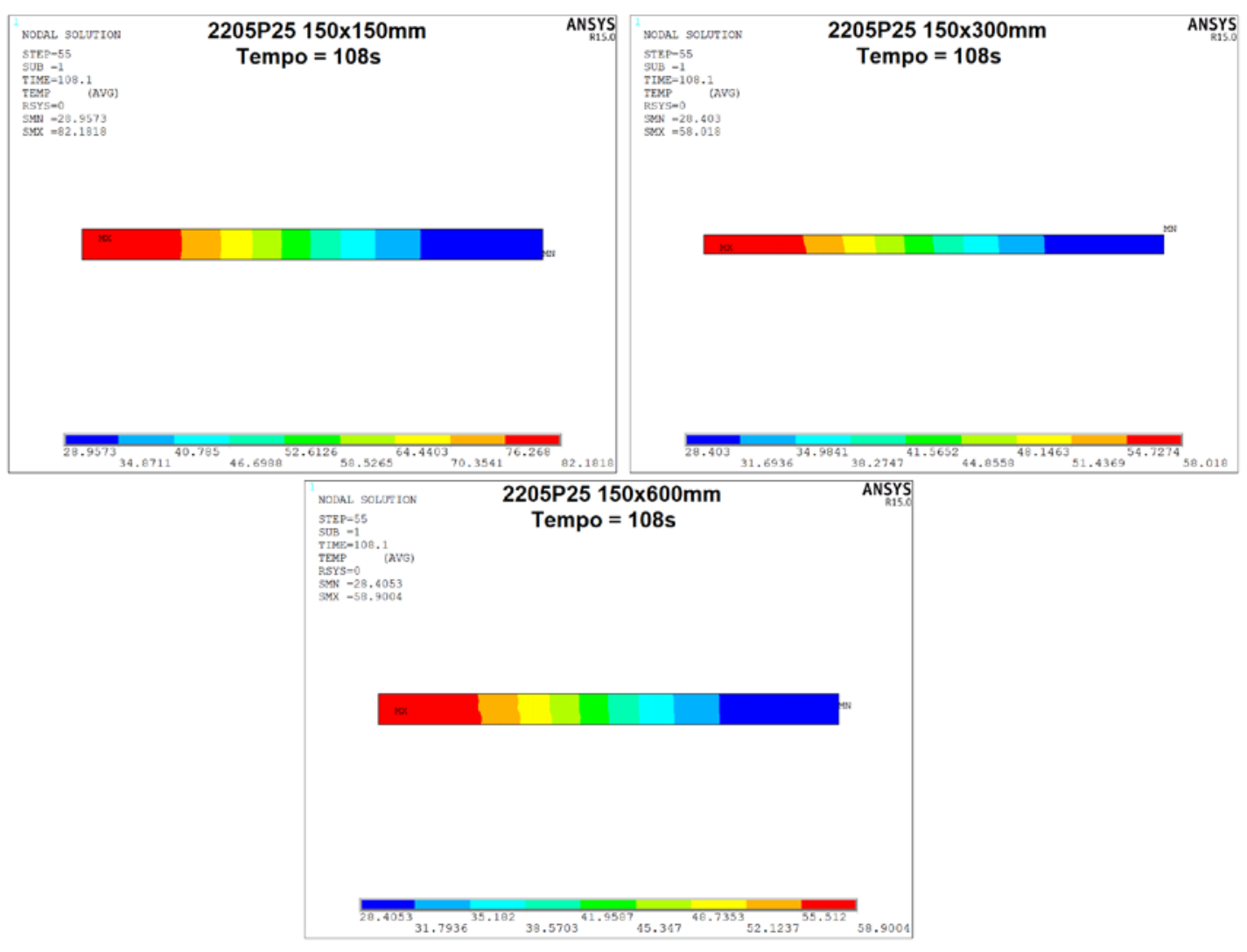

Figura 7.11: Perfil de temperatura da amostra 2205P25, para as 3 condições de tamanho geométrico, no tempo de $108 \mathrm{~s}$.

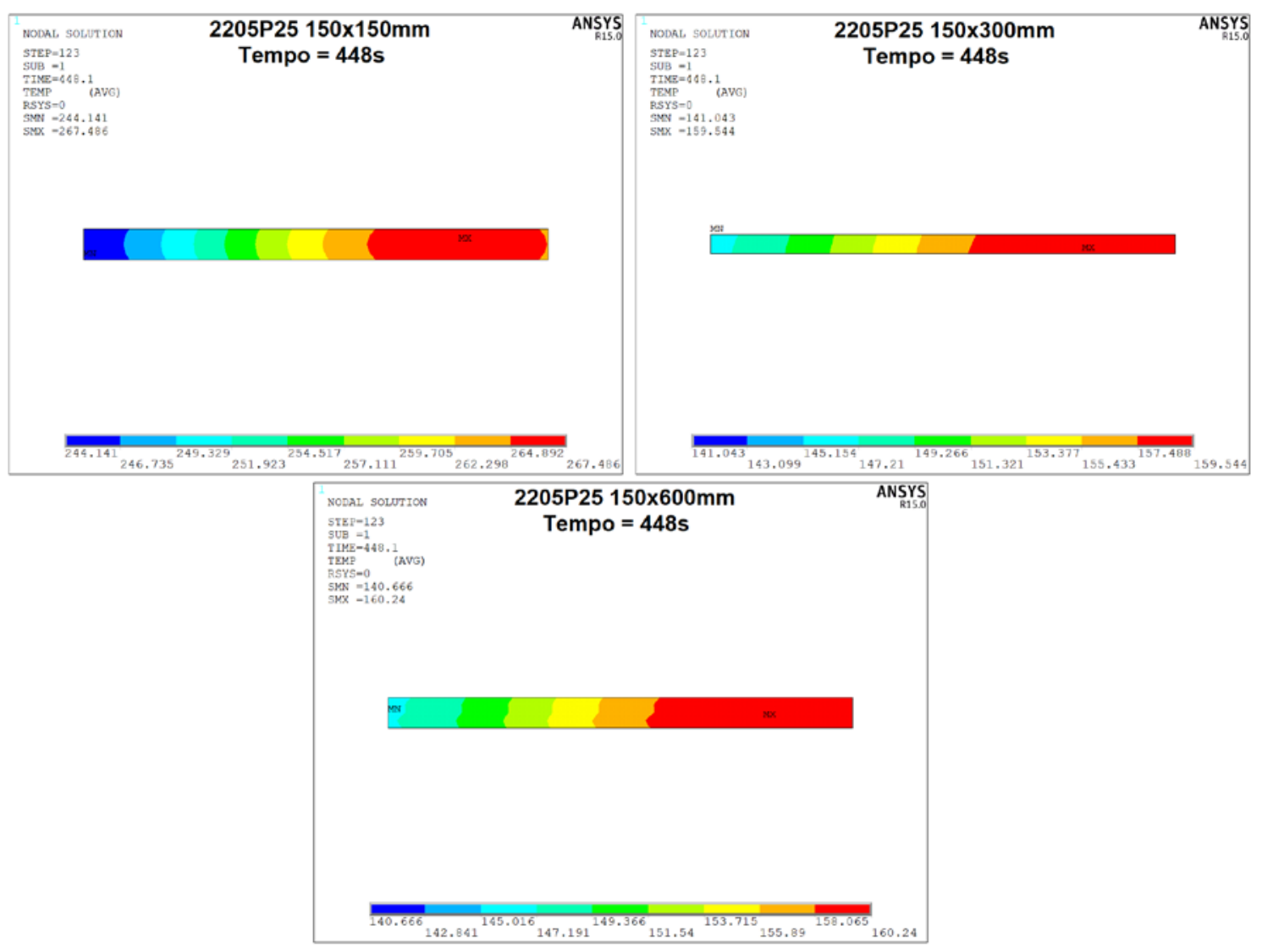

Figura 7.12: Perfil de temperatura da amostra 2205P25, para as 3 condições de tamanho geométrico, no tempo de 448s. 


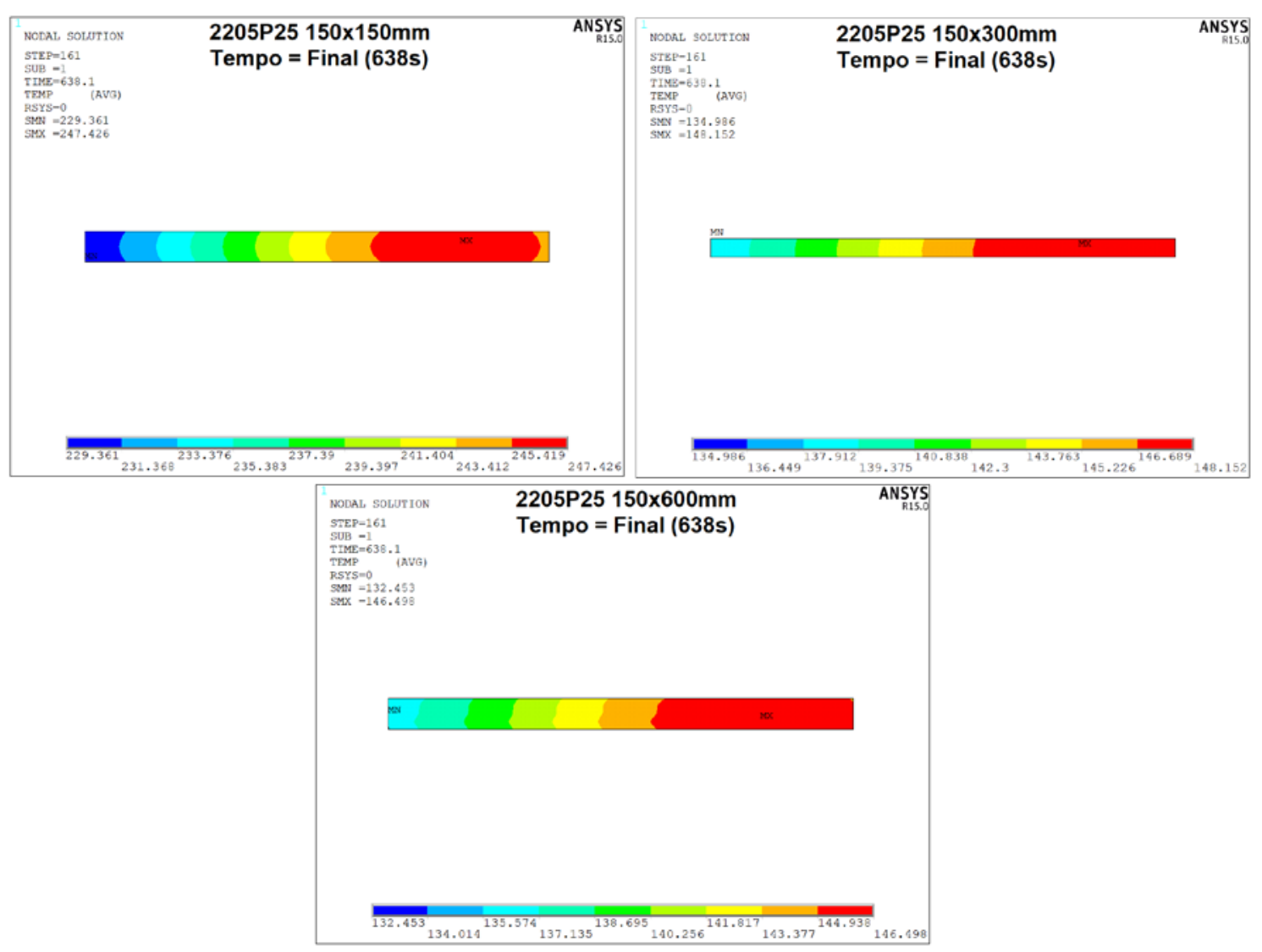

Figura 7.13: Perfil de temperatura da amostra 2205P25, para as 3 condições de tamanho geométrico, no tempo final de aquisição dos dados, 638s.

Nesta primeira comparação, para o tempo de 108s (figura 7.11) observouse que a distribuição da temperatura foi semelhante em todos os casos, para as 3 geometrias adotadas, mas que as os valores das temperaturas foram amplamente distintos quando se trata da chapa de 150x50mm para as outras duas. Como a intenção pretendida é comparar o impacto dessas dimensões geométricas perante as temperaturas, em uma região específica da amostra $(75 \mathrm{~mm}$ do centro do cordão de solda), foram montadas tabelas que apresentam os valores absolutos das diferenças de temperaturas mínima e máxima em cada caso. As diferenças percentuais nas temperaturas estão anotadas a seguir, na tabela 7.2, para as chapas com 150x150mm em relação à de 150x300mm (todas as temperaturas são apresentadas em graus Celsius “ ${ }^{\circ} \mathrm{C}$ ”). 
Tabela 7.2: Diferenças absolutas entre as temperaturas mínimas e máximas da amostra 2205P25, para os 3 tempos adotados, entre as geometrias $150 \times 150 \mathrm{~mm}$ e $150 \times 300 \mathrm{~mm}$.

\begin{tabular}{|c|c|c|c|c|c|c|}
\hline 2205P25 & $\mathrm{T}_{\min 108 \mathrm{~S}}$ & $\mathrm{~T}_{\min } 448 \mathrm{~s}$ & $\mathrm{~T}_{\min 638 \mathrm{~S}}$ & $\mathrm{~T}_{\text {máx 108s }}$ & $\mathrm{T}_{\text {máx 448s }}$ & $\mathrm{T}_{\text {máx } 638 \mathrm{~S}}$ \\
\hline 150x150mm & 28,9573 & 244,141 & 229,361 & 82,1818 & 267,486 & 247,426 \\
\hline $150 \times 300 \mathrm{~mm}$ & 28,403 & 141,043 & 134,986 & 58,018 & 159,544 & 148,152 \\
\hline Dif (\%) & 1,91 & 42,23 & 41,15 & 20,40 & 40,35 & 40,12 \\
\hline
\end{tabular}

Notórias as diferenças nas temperaturas mínimas e máximas para este caso recém apresentado, com diferenças acima de 40\%, apenas não sendo explicita essa correlação no primeiro tempo adotado. No tempo de 108s, ainda não havia um grande fluxo térmico na região analisada, sendo que em determinado ponto da região, ainda permanecia em temperatura inicial de 28 graus. Nos tempos seguintes, tanto intermediário (448s) quanto final (638s), as diferenças na temperatura são elevadas, revelando alguma discrepância entre os tamanhos comparados.

Quando partimos para a comparação relativa das chapas de 150x300mm com a de $150 \times 600 \mathrm{~mm}$, temos a seguinte tabela 7.3, com os seguintes dados:

Tabela 7.3: Diferenças absolutas entre as temperaturas mínimas e máximas da amostra 2205P25, para os 3 tempos adotados, entre as geometrias $150 \times 300 \mathrm{~mm}$ e $150 \times 600 \mathrm{~mm}$.

\begin{tabular}{|c|c|c|c|c|c|c|}
\hline 2205P25 & $\mathrm{T}_{\min 108 \mathrm{~s}}$ & $\mathrm{~T}_{\min 448 \mathrm{~s}}$ & $\mathrm{~T}_{\min } 638 \mathrm{~s}$ & $\mathrm{~T}_{\text {máx 108s }}$ & $\mathrm{T}_{\text {máx } 448 \mathrm{~s}}$ & $\mathrm{~T}_{\text {máx } 638 \mathrm{~s}}$ \\
\hline $150 \times 300 \mathrm{~mm}$ & 28,403 & 141,043 & 134,986 & 58,018 & 159,544 & 148,152 \\
\hline $150 \times 600 \mathrm{~mm}$ & 28,4053 & 140,666 & 132,453 & 58,9004 & 160,24 & 146,498 \\
\hline Dif (\%) & 0,008 & 0,27 & 1,88 & 1,45 & 0,43 & 1,12 \\
\hline
\end{tabular}

Para este segundo caso de comparação, todas as temperaturas comparadas, em todos os tempos, ficam abaixo da diferença absoluta de $2 \%$. Mostrando assim que mesmo dobrando a distribuição lateral da geometria da chapa, o impacto sobre o perfil de temperatura, analisada a $75 \mathrm{~mm}$ do centro do cordão, permanece praticamente sem alteração.

Essas comparações foram feitas para um dos materiais estudados, o aço 2205, no aporte térmico mais alto utilizado, $2,5 \mathrm{KJ} / \mathrm{mm}$. Um procedimento equivalente foi adotado para o outro material estudado, o 2304, sob o mesmo aporte térmico, $2,5 \mathrm{KJ} / \mathrm{mm}$, onde os perfis de temperatura são mostrados a seguir, nas figuras $7.14-7.16$ : 


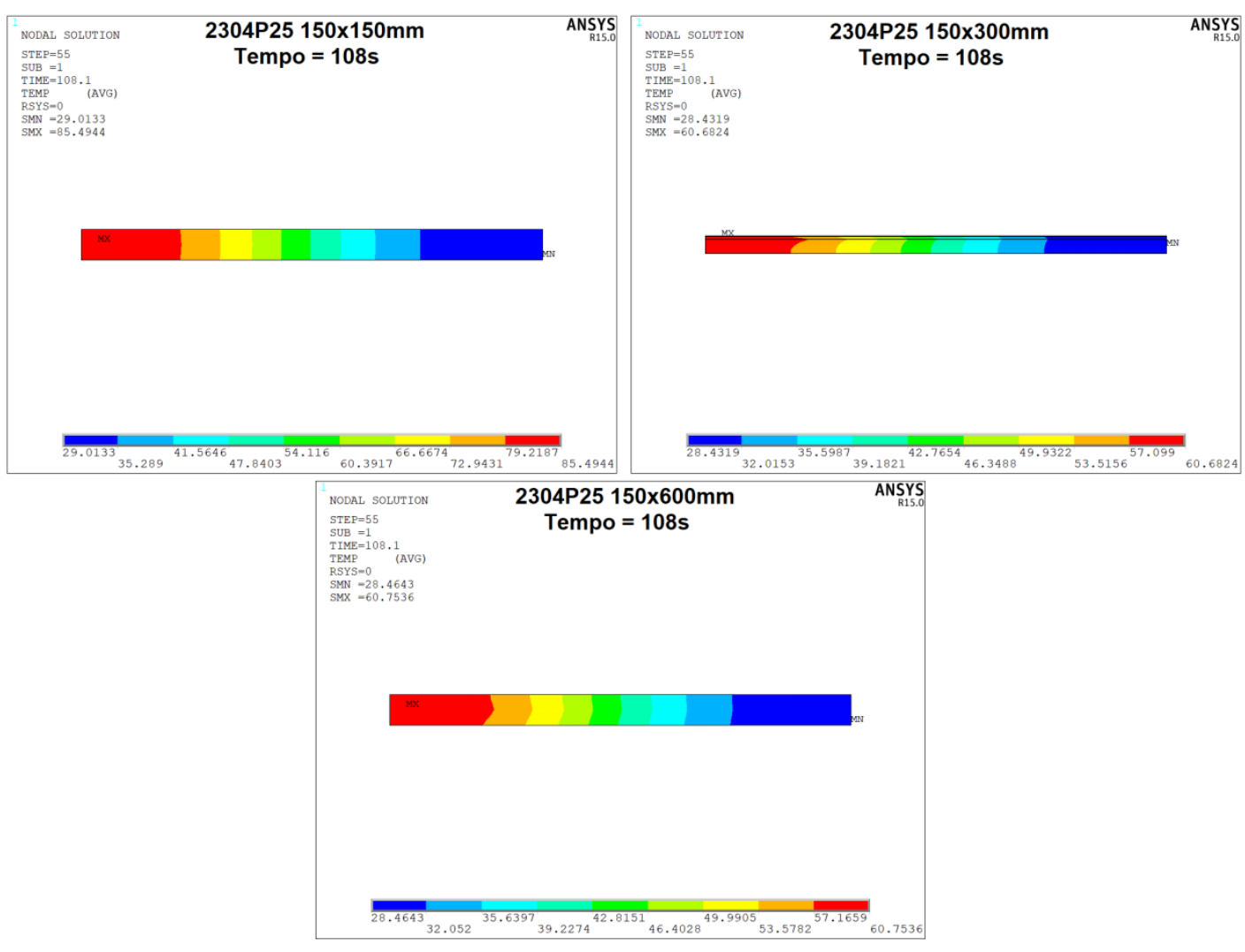

Figura 7.14: Perfil de temperatura da amostra 2304P25, para as 3 condições de tamanho geométrico, no tempo final de aquisição dos dados, 108s.

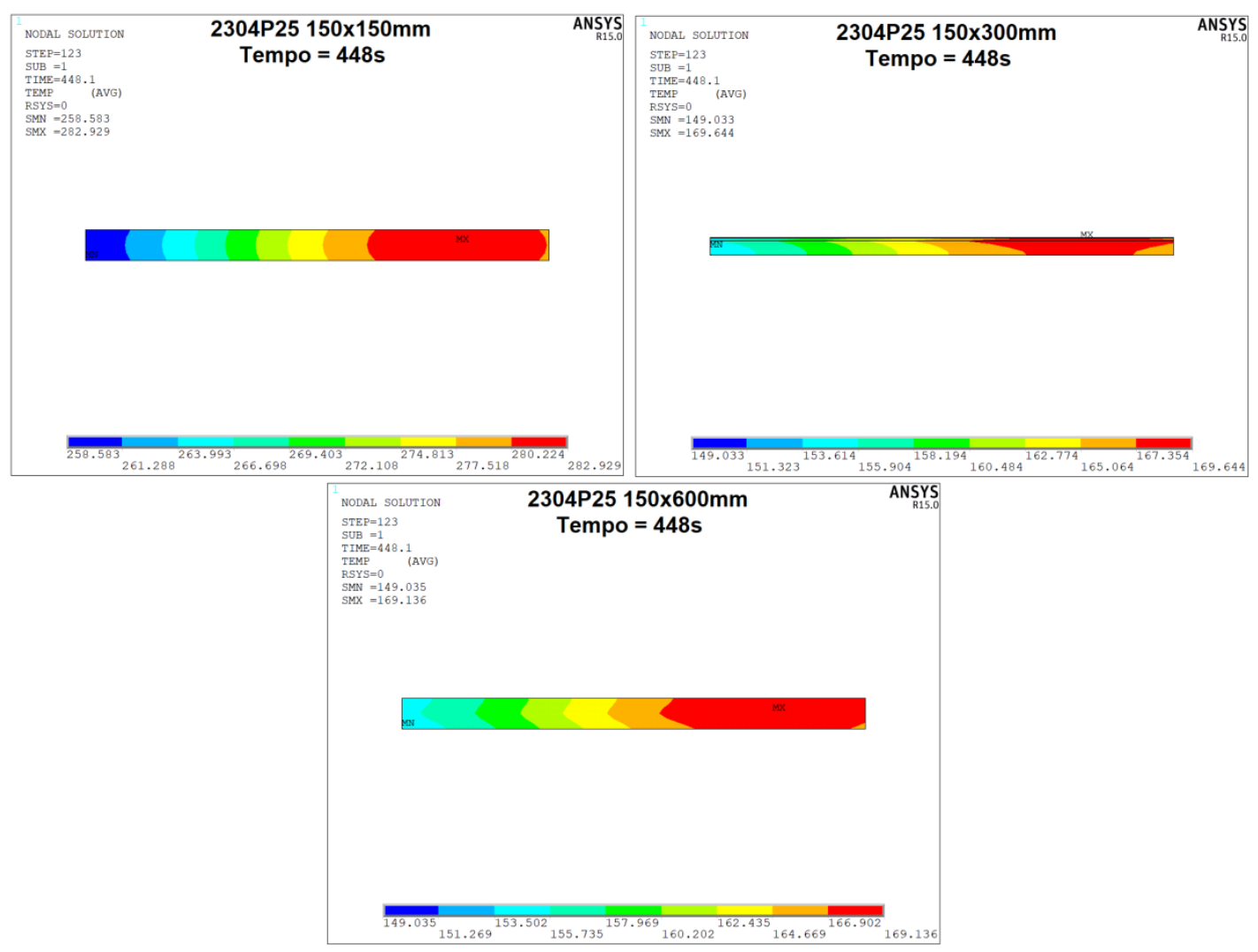

Figura 7.15: Perfil de temperatura da amostra 2304P25, para as 3 condições de tamanho geométrico, no tempo final de aquisição dos dados, $448 \mathrm{~s}$. 


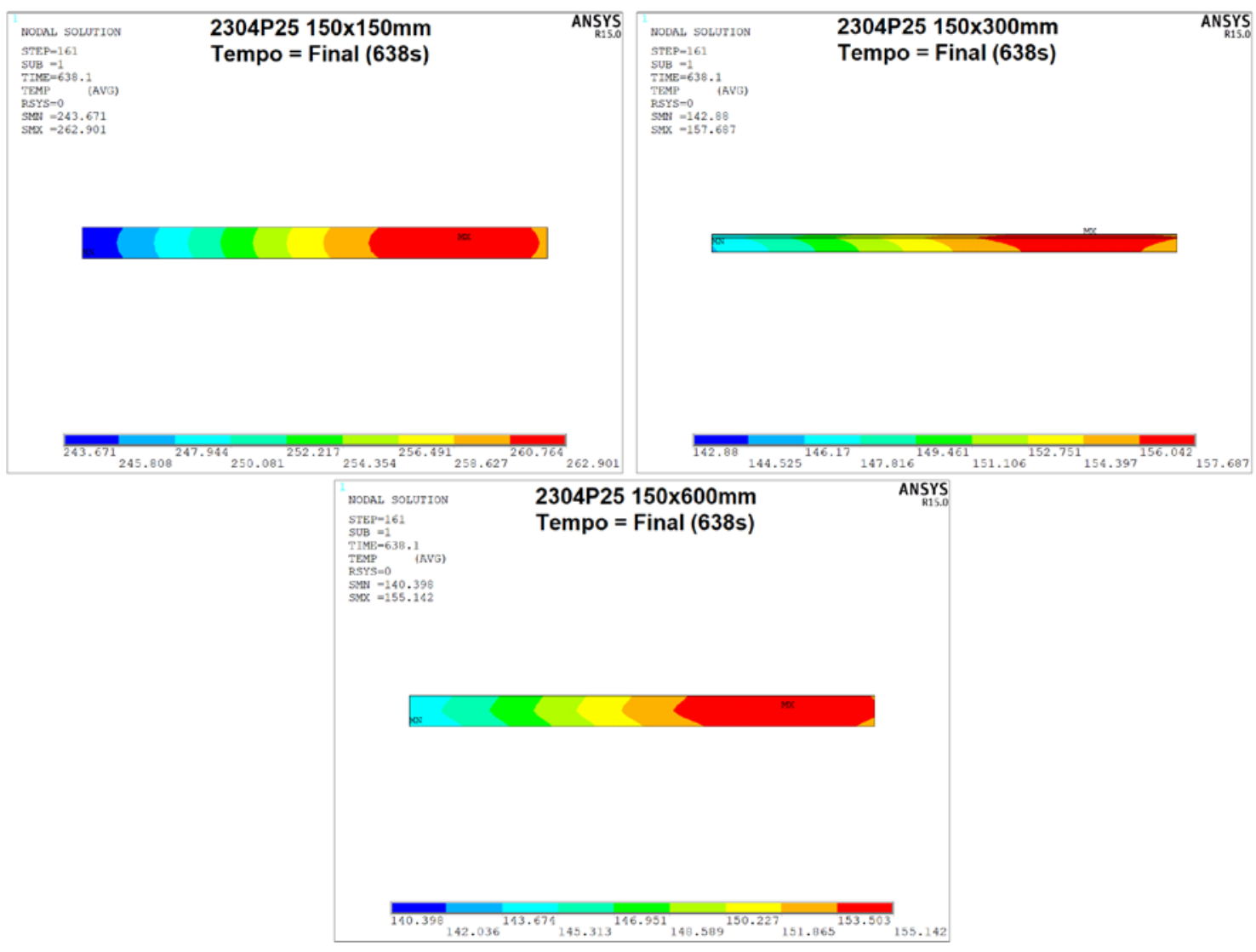

Figura 7.16: Perfil de temperatura da amostra 2304P25, para as 3 condições de tamanho geométrico, no tempo final de aquisição dos dados, 638s.

O comportamento foi semelhante ao da amostra anterior, para os três tempos empregados, a distribuição dos perfis de temperatura são aproximados, mas as temperaturas claramente destoantes, principalmente em se tratando da geometria 150x150mm com relação às outras duas analisadas. Novamente, duas tabelas 7.4 e 7.5, são construídas explicitando os valores das diferenças absolutas entre as três distintas geometrias, admitindo-se todos os outros parâmetros de soldagem idênticos.

Tabela 7.4: Diferenças absolutas entre as temperaturas mínimas e máximas da amostra 2304P25, para os 3 tempos adotados, entre as geometrias $150 \times 150 \mathrm{~mm}$ e $150 \times 300 \mathrm{~mm}$.

\begin{tabular}{|c|c|c|c|c|c|c|}
\hline 2304P25 & $\mathrm{T}_{\text {mín } 108 \mathrm{~s}}$ & $\mathrm{~T}_{\min 448 \mathrm{~s}}$ & $\mathrm{~T}_{\min 638 \mathrm{~s}}$ & $\mathrm{~T}_{\text {máx }}$ 108s & $\mathrm{T}_{\text {máx 448s }}$ & $\mathrm{T}_{\text {máx 638s }}$ \\
\hline 150x150mm & 29,0133 & 258,583 & 243,671 & 85,4944 & 282,929 & 262,901 \\
\hline $150 \times 300 \mathrm{~mm}$ & 28,4319 & 149,033 & 142,88 & 60,6824 & 169,644 & 157,678 \\
\hline Dif (\%) & 2,00 & 42,36 & 41,36 & 29,022 & 40,04 & 40,02 \\
\hline
\end{tabular}


Tabela 7.5: Diferenças absolutas entre as temperaturas mínimas e máximas da amostra 2304P25, para os 3 tempos adotados, entre as geometrias $150 \times 300 \mathrm{~mm}$ e $150 \times 600 \mathrm{~mm}$.

\begin{tabular}{|c|c|c|c|c|c|c|}
\hline 2304P25 & $\mathrm{T}_{\min 108 \mathrm{~S}}$ & $\mathrm{~T}_{\min } 448 \mathrm{~s}$ & $\mathrm{~T}_{\min 638 \mathrm{~S}}$ & $\mathrm{~T}_{\text {máx 108s }}$ & $\mathrm{T}_{\text {máx 448s }}$ & $\mathrm{T}_{\text {máx } 638 \mathrm{~S}}$ \\
\hline $150 \times 300 \mathrm{~mm}$ & 28,4319 & 149,033 & 142,88 & 60,6824 & 169,644 & 157,678 \\
\hline $150 \times 600 \mathrm{~mm}$ & 28,4643 & 149,035 & 140,398 & 60,7536 & 169,136 & 155,142 \\
\hline Dif (\%) & 0,11 & 0,001 & 1,74 & 0,12 & 0,30 & 1,61 \\
\hline
\end{tabular}

Analogamente, as diferenças entre as geometrias 150x150mm e 150x300mm, ficaram acima de 40\%, sendo menores os valores para o primeiro tempo empregado. Já para a outra comparação, entre 150x300mm e 150x600mm, as diferenças ficaram novamente abaixo de 2\%. Mostrando assim um comportamento bastante semelhante dos dois materiais estudados, 2205 e 2304.

Quando a análise é repetida, da mesma maneira, para as amostras 2205P15 e 2304P15 que foram soldadas com menor aporte térmico, os comportamentos são bastante semelhantes aos já recém apresentados. A única distinção é que as diferenças absolutas são menores entre as comparações, uma vez que o gradiente térmico é menor na chapa, pois uma menor energia de soldagem é aplicada nessas amostras.

Os resultados indicam que o efeito das bordas pode ser desprezado na direção transversal à direção de soldagem, para as chapas grandes aqui utilizadas, com dimensões 150x300mm. Esta hipótese não pode ser utilizada para as chapas pequenas, com dimensões 150x150mm, onde o efeito das bordas fica evidenciado. Constata-se ainda que, no caso das chapas grandes, o mecanismo de transferência de calor na direção transversal à solda preponderante é aquele associado ao processo de condução de calor na amostra, sendo este mais efetivo do que a convecção térmica.

\subsection{2}

\section{Validação do Modelo Numérico}

Duas metodologias foram adotadas para a validação dos modelos, quanto à calibração dos mesmos: 
- as comparações diretas dos ciclos térmicos obtidos nos experimentos, através dos 5 termopares, com os colhidos nos modelos numéricos nas respectivas posições espaciais; e

- a verificação e comparação da profundidade da ZF prevista pelos modelos com os valores experimentais obtidos via análise macrográfica das amostras soldadas.

\subsection{3}

\section{Calibração dos Modelos}

A calibração dos modelos é realizada através do ajuste dos parâmetros $a$, $b, c_{1}$ e $c_{2}$ referentes à fonte de calor do modelo duplo elipsoide de Goldak, apresentado pela equação (4.3).Além disso, são considerados os parâmetros reais de soldagem como a tensão, corrente e velocidade de soldagem utilizados no momento da execução do cordão sob chapa experimental.

Para cada conjunto de experimentos desenvolveu-se uma simulação numérica correspondente, sendo ajustados os parâmetros dimensionais da fonte de calor em cada etapa. As amostras foram separadas em 2 conjuntos, distintas pelo aporte térmico aplicado, 1,5 e 2,5 KJ/mm.

Os dados obtidos foram confrontados com os valores de temperatura aquisitados pelos 5 termopares de cada corpo de prova e na medição da profundidade da ZF com a análise metalográfica. O ajuste dos parâmetros no modelo numérico é de fundamental importância para que a distribuição de temperaturas ao longo da junta soldada possa ser correlacionada com a análise experimental em questão.

Os parâmetros $a$ e $b$ estão relacionados com as dimensões da largura e da profundidade da fonte de calor, respectivamente, que por sua vez, estão relacionados com a largura e profundidade da ZTA e ZF. O comprimento da fonte de calor está relacionado com os parâmetros $c_{1}$ e $c_{2}$, onde o primeiro está associado à frontal, e o segundo à parte posterior da fonte de calor, conforme ilustrado na Figura 4.3. Os4 parâmetros geométricos do modelo da fonte de calor foram ajustados de modo a se obter nas simulações numéricas uma boa concordância com os valores dos ciclos térmicos experimentais. Em uma etapa 
posterior, os parâmetros foram reajustados com o intuito de se obter uma profundidade da ZF próxima àquela revelada na análise macrográfica.

Durante o processo de calibração do modelo, o critério utilizado para definir o tamanho da ZF consiste em identificar a região da chapa que apresentou temperatura superior à temperatura de fusão do material, definida previamente como sendo $1470^{\circ} \mathrm{C}$, durante o processo de soldagem. Uma imagem é gerada no instante em que essa região é máxima para a seção transversal à solda, e possa ser feita a comparação com os valores obtidos na análise macrográfica.

Analisando então os dois conjuntos de amostras diferenciados pelos aportes térmicos, o modelo numérico foi devidamente calibrado utilizando-se as 4 amostras de cada uma das condições.

\subsubsection{1}

\section{Amostras Aporte Térmico Menor - 1,5kJ/mm}

Foi usado o mesmo conjunto de parâmetros dimensionais da fonte de calor para cada aporte térmico, como já mencionado anteriormente. Uma das premissas iniciais de se utilizar um modelo numérico simplificado, como este mostrado no presente trabalho, é que consiga descrever o fenômeno físico real, descrevendo o máximo de situações possíveis. Por isso, a calibração do modelo, se utilizando desse conceito, deve ser válida igualmente para cada aporte térmico empregado. Esta separação - por aporte - acontece, pois através do aumento da velocidade de soldagem os contornos das isotermas tendem a se alongar mais em direção ao sentido contrário a soldagem, afetando uma zona menor (CHON, 1993). Com base nessa informação, uma vez que a velocidade de soldagem foi mantida constante dentro do mesmo aporte térmico, o conjunto de valores dos parâmetros geométricos descritos para o modelo de Goldak, deve permanecer o mesmo.

A seguir serão mostrados os resultados da calibração do modelo apenas das amostras relacionadas à chapas grandes, com geometria de 150x300mm, pois como discutido na seção 7.2.1, as amostras com dimensões menores apresentaram efeito de borda.

Os resultados obtidos na calibração dos parâmetros geométricos do modelo da fonte de calor referentes às amostras com aporte térmico de 1,5KJ/mm, são exibidos na tabela 7.6. 
Tabela 7.6: Parâmetros do modelo da fonte de calor para as amostras com aporte térmico de $1,5 \mathrm{KJ} / \mathrm{mm}$.

\begin{tabular}{|c|c|c|c|c|}
\hline & $\boldsymbol{a}(\mathbf{m m})$ & $\boldsymbol{b}(\mathbf{m m})$ & $\boldsymbol{c}_{\mathbf{1}}(\mathbf{m m})$ & $\boldsymbol{c}_{\mathbf{2}}(\mathbf{m m})$ \\
\hline $\mathbf{1 , 5} \mathbf{~ K J} / \mathbf{m m}$ & 11,0 & 6,0 & 8,0 & 16,0 \\
\hline
\end{tabular}

Foram desenvolvidas diversas combinações de parâmetros com o objetivo de obter uma combinação que apresentasse valores de temperaturas e profundidade da ZF compatíveis aos resultados experimentais.

\section{Amostra 2205G15}

Empregando no modelo os valores geométricos ajustados para a fonte de calor, o ciclo térmico conforme o exibido na figura 7.17, é adquirido. O modelo se ajustou adequadamente tanto nas etapas de aquecimento quanto de resfriamento do material, estando em boa concordância.

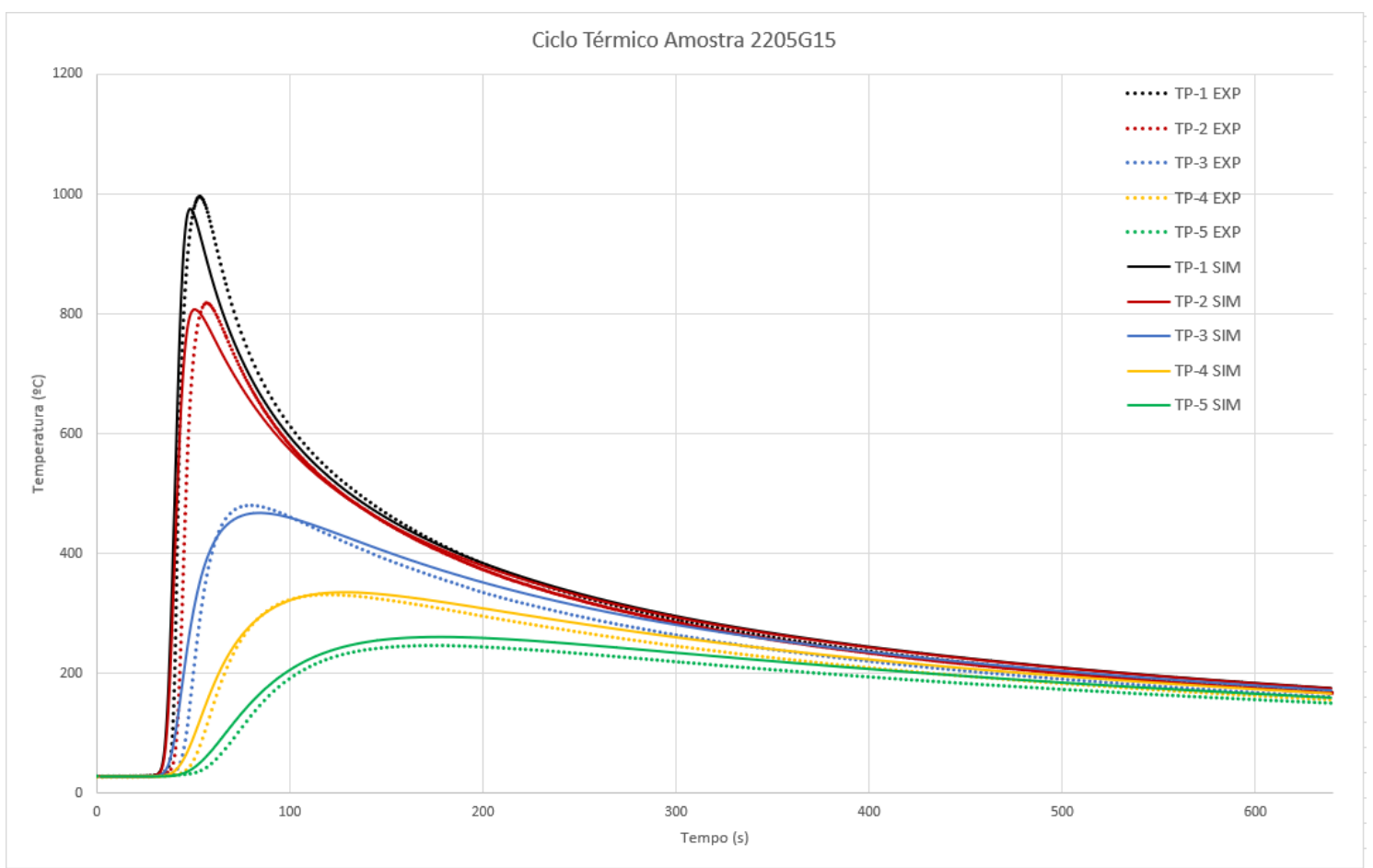

Figura 7.17: Comparação entre o ciclo térmico adquirido do processo experimental e o numericamente simulado para a amostra 2205G15.

Existe uma pequena diferença no atraso dos dados comparados, onde a simulação adquiriu dados em uma posição anterior à dos termopares acoplados à 
chapa. Essa diferença aconteceu devido a um pequeno deslocamento dos furos com relação ao planejado inicialmente.

A tabela 7.7 mostra o maior erro relativo às temperaturas de pico encontradas para os 5 termopares, como sendo um erro menor do que 6\%, para o termopar 5. Seria esperado encontrar a maior divergência das temperaturas de pico em regiões próximas à fonte de calor (nos dois primeiros termopares), devido aos maiores gradientes térmicos presentes nessas regiões espaciais. Como consequência, maiores valores de fluxo de calor estão presentes e os resultados numéricos tendem a divergir mais dos reais aquisitados. Este erro relativo (5,42\%), ainda que pequeno, pode estar associado aduas possíveis condições: diferença entre o posicionamento do termopar e o nó do modelo utilizado para obter a temperatura e a utilização de uma representação simplificada do coeficiente de convecção.

Tabela 7.7: Diferenças absolutas entre as temperaturas de pico registradas no experimento e encontradas na simulação numérica para a amostra 2205G15.

\begin{tabular}{|c|c|c|c|c|c|}
\hline 2205G15 & TP-1 & TP-2 & TP-3 & TP-4 & TP-5 \\
\hline EXP & 996,68 & 818,69 & 480,78 & 331,58 & 246,76 \\
\hline SIM & 975 & 807,4 & 467,9 & 335,4 & 260,9 \\
\hline DIF (\%) & 2,18 & 1,38 & 2,68 & 1,14 & 5,42 \\
\hline
\end{tabular}

A profundidade de penetração da linha de fusão para esta amostra foi de 2,6mm, medida através de análise macrográfica, e na simulação foi encontrado um valor de 2,7mm para esta mesma grandeza, conforme figura 7.18, com uma diferença absoluta no valor de 3,70\%. Também é mostrado a altura do cordão de solda para essa amostra, baseado na análise metalográfica. 


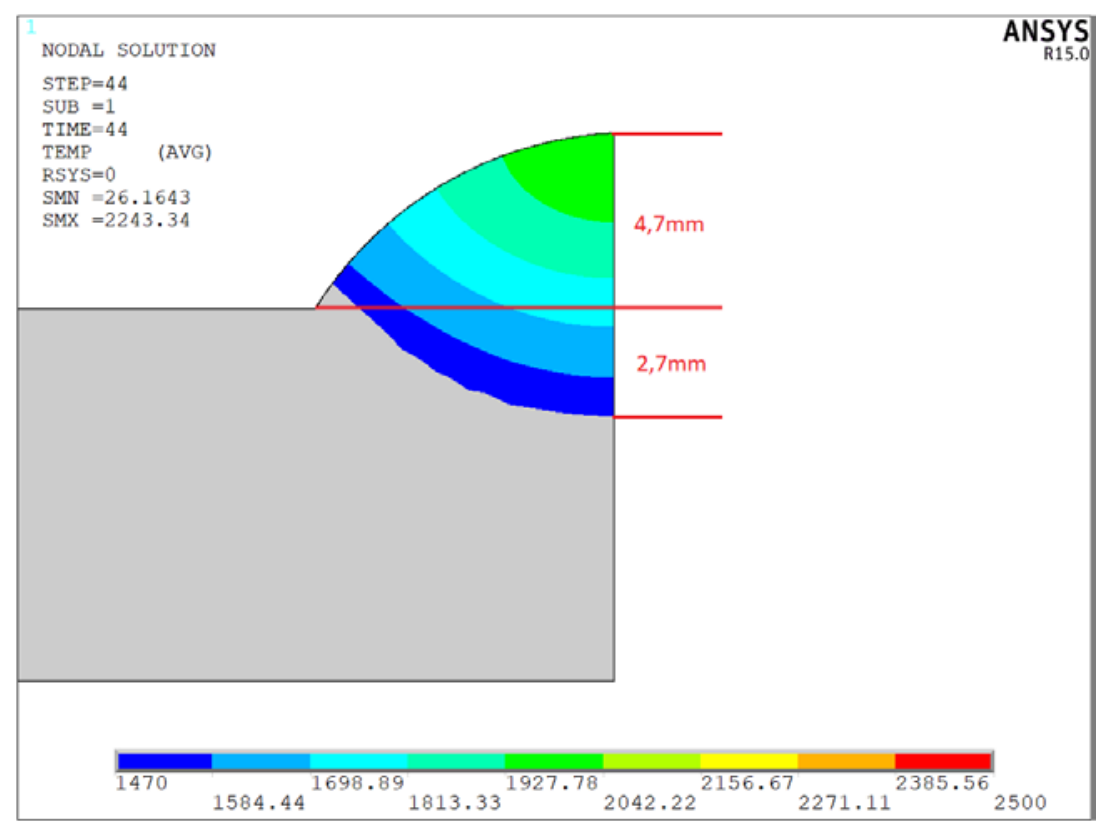

Figura 7.18: Imagem da ZF da amostra 2205G15.

A região mostrada na intersecção do cordão de solda da amostra com a chapa, mostrada na figura 7.18, onde parece não estar fundida, pode ser explicada devido a alguns fatores, a saber: a temperatura de fusão varia entre uma faixa de valores, a posição da fonte de calor no modelo estar sendo assumida no topo do cordão de solda, desconsideração dos efeitos da convecção do material na poça de fusão e sua possível influência no formato final do cordão de solda, o modelo ser simplificado não exibindo exatamente o perfil da zona fundida real. Esse problema já foi exibido na literatura em outros trabalhos (ALMEIDA et. al., 2016; XAVIER et. al., 2013), e no presente trabalho essa região "não fundida” do cordão de solda representa uma parcela diminuta do mesmo.

\section{Amostra 2304G15}

Da mesma forma que para a amostra anterior, utilizando os mesmos parâmetros geométricos do modelo da fonte de calor, o ciclo térmico obtido é mostrado na figura 7.19. Tanto para o aquecimento quanto para o resfriamento natural da amostra, os valores das temperaturas são bastante próximos e o comportamento assintótico das curvas se assemelham. 


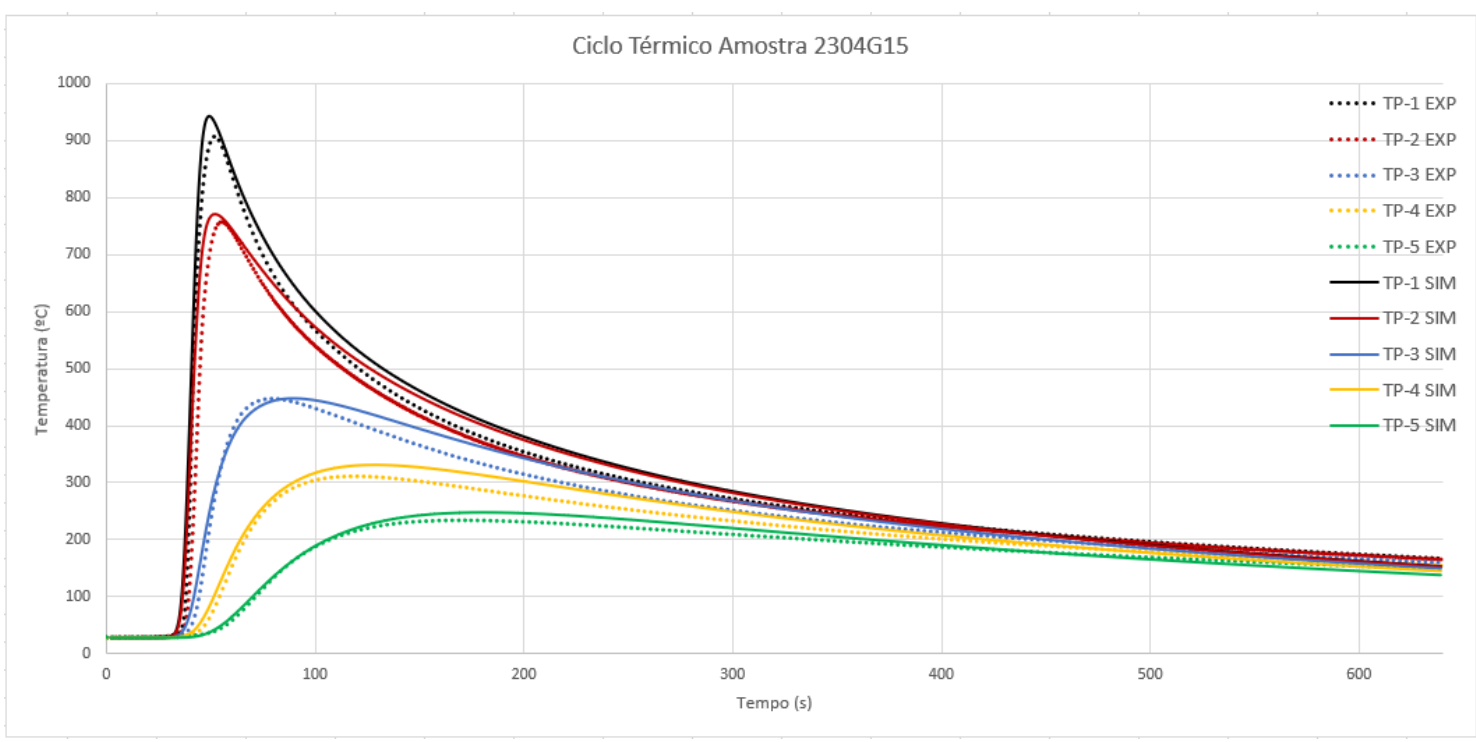

Figura 7.19: Comparação entre o ciclo térmico adquirido do processo experimental e o numericamente simulado para a amostra 2304G15.

A tabela 7.8 mostra o maior erro relativo às temperaturas de pico encontradas para os 5 termopares acoplados à chapa, como sendo um erro também menor do que 6\%, para o termopar 4 . Da mesma forma que a amostra anterior, os maiores erros relativos se encontram nos últimos termopares.

Tabela 7.8: Diferenças absolutas entre as temperaturas de pico registradas no experimento e encontradas na simulação numérica para a amostra 2304G15.

\begin{tabular}{|c|c|c|c|c|c|}
\hline 2304G15 & TP-1 & TP-2 & TP-3 & TP-4 & TP-5 \\
\hline EXP & 907,34 & 757,56 & 447,49 & 311,44 & 234,20 \\
\hline SIM & 942,8 & 771,1 & 447,9 & 331,3 & 247,9 \\
\hline DIF (\%) & 3,76 & 1,76 & 0,09 & 5,99 & 5,53 \\
\hline
\end{tabular}

A penetração da linha de fusão para esta amostra foi de $2,7 \mathrm{~mm}$, medida através de análise macrográfica, e na simulação foi encontrado um valor idêntico para esta grandeza, conforme figura 7.20. Também é mostrado a altura do cordão de solda para essa amostra, baseado na análise metalográfica. 


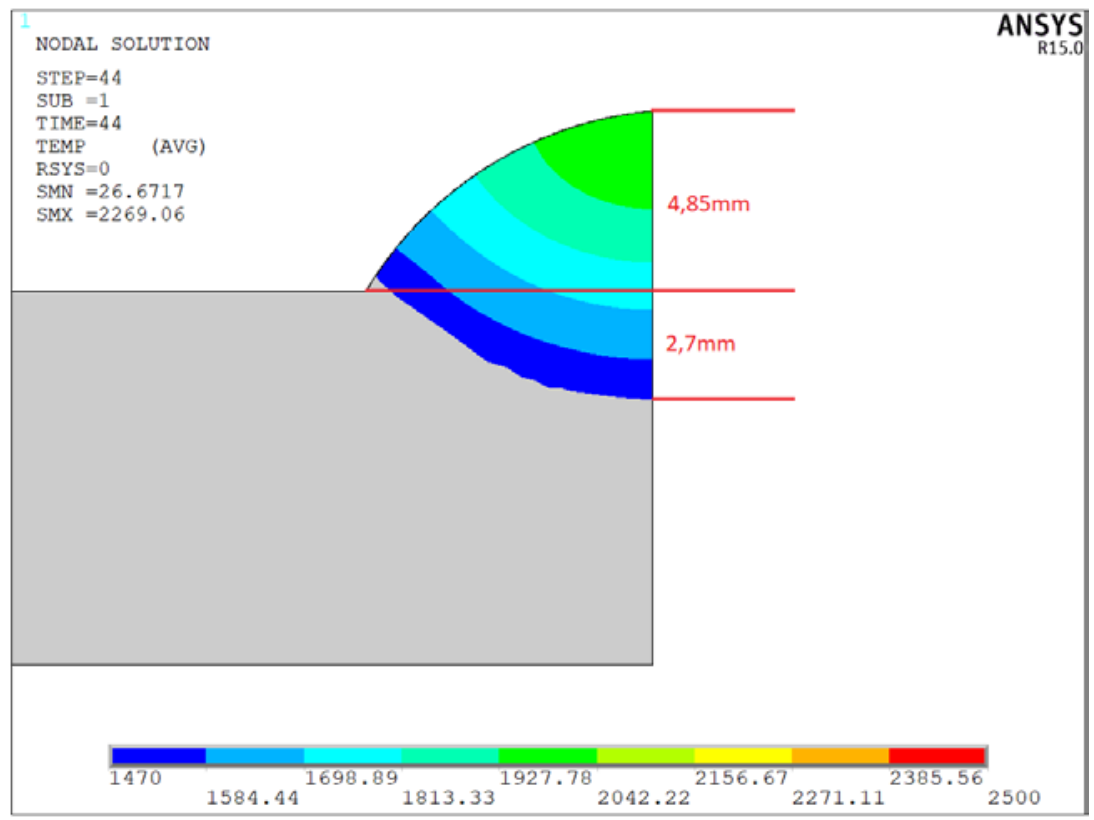

Figura 7.20: Imagem da ZF da amostra 2304G15.

\subsubsection{2}

\section{Amostras Aporte Térmico Maior - 2,5kJ/mm}

Partindo de um princípio idêntico utilizado nas amostras de menor aporte térmico, um mesmo conjunto de parâmetros dimensionais da fonte de calor foi usado em todas as amostras de maior aporte térmico, pois a velocidade de soldagem em questão foi a mesma. Sendo assim, a seguir serão mostrados os resultados da calibração do modelo para as amostras soldadas com o maior aporte térmico empregado no trabalho.

Os resultados obtidos na calibração dos parâmetros geométricos do modelo da fonte de calor referentes às amostras com aporte térmico de $2,5 \mathrm{KJ} / \mathrm{mm}$, são exibidos na tabela 7.9. Como era de se esperar, o duplo elipsoide se mostra geometricamente maior para um maior aporte térmico.

Tabela 7.9: Parâmetros do modelo da fonte de calor para as amostras com aporte térmico de $2,5 \mathrm{KJ} / \mathrm{mm}$.

\begin{tabular}{|c|c|c|c|c|}
\hline & $\boldsymbol{a} \mathbf{( m m})$ & $\boldsymbol{b} \mathbf{( m m})$ & $\boldsymbol{c}_{\mathbf{1}}(\mathbf{m m})$ & $\boldsymbol{c}_{\mathbf{2}}(\mathbf{m m})$ \\
\hline $\mathbf{2 , 5} \mathbf{~ K J} / \mathbf{m m}$ & 17,0 & 8,0 & 15,0 & 20,0 \\
\hline
\end{tabular}

Também aqui foram desenvolvidas inúmeras combinações de parâmetros com o objetivo de obter uma combinação que apresentasse valores de 
temperaturas e penetração da ZF compatíveis aos resultados experimentais avaliados. Como já relatado anteriormente, as isotermas relacionadas ao modelo da fonte de calor empregado se modificam, à medida que o aporte térmico é alterado (CHON, 1993), o que acaba por comprovar tal sequencia metodológica.

Por se tratar de um aporte térmico maior aplicado nas amostras, o gradiente de temperatura consequentemente é superior ao caso anterior apresentado, com isso, resultados igualmente apropriados tendem a ser mais difíceis de serem alcançados, principalmente para as regiões próximas ao cordão de solda (onde estão os termopares envolvidos em uma distribuição de gradiente térmico mais elevada). Como já discutido anteriormente (seção 7.2.1), o processo de convecção térmica é definido, para o modelo, como constante e atribuído a valores discretos. Para esse caso de maiores energias aportadas às amostras, foram atribuídos então dois valores, ainda discretos, de convecção térmica, com o intuito de descrever esse processo de maneira mais adequada.

\section{Amostra 2205G25}

Empregando no modelo, agora os novos valores geométricos ajustados para a fonte de calor, o ciclo térmico encontrado é exibido na figura 7.21. O modelo apresentou ciclos térmicos que se mostraram satisfatoriamente próximos aos experimentais, tanto para as etapas de aquecimento quanto de resfriamento do material, assumindo uma adequada concordância. 


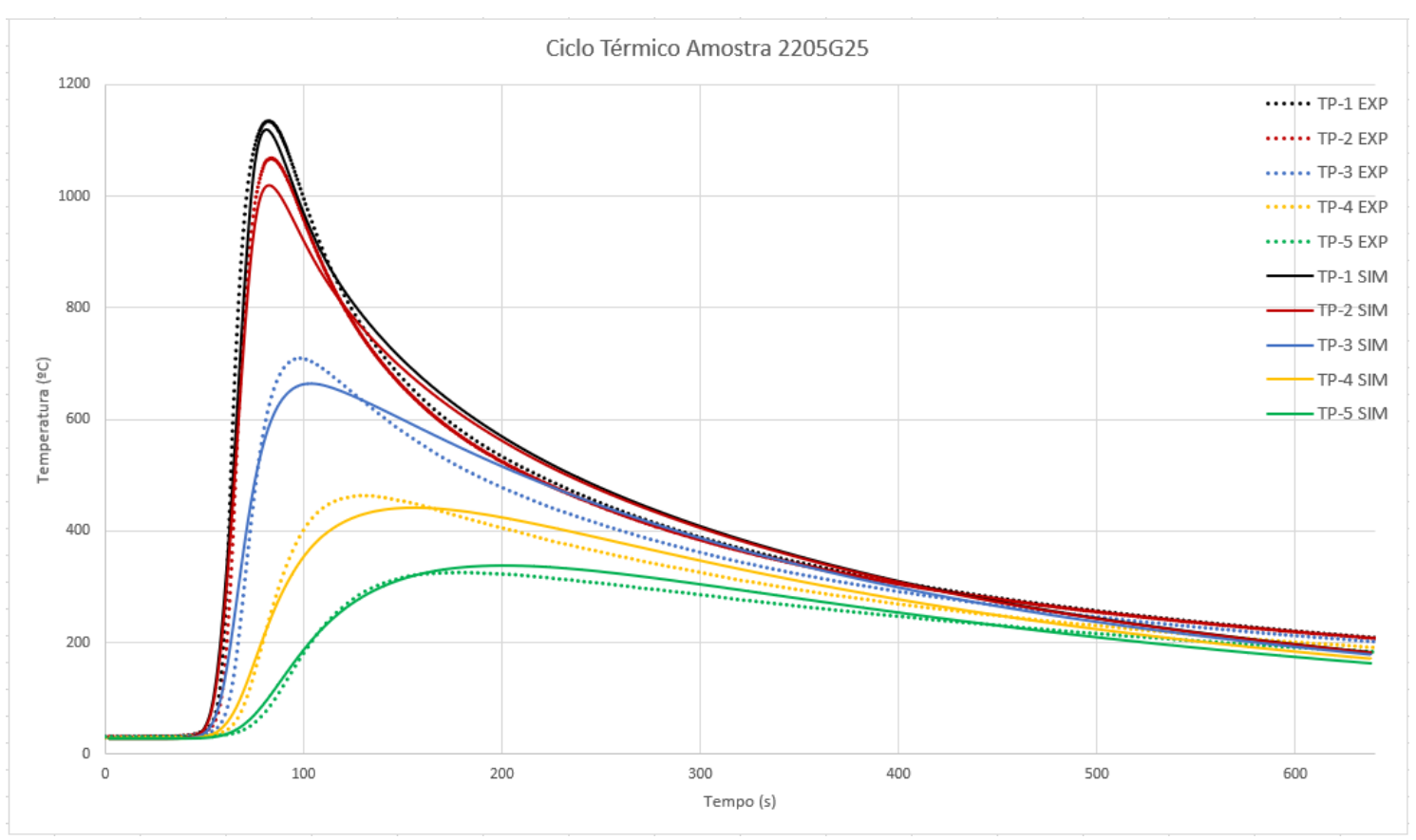

Figura 7.21: Comparação entre o ciclo térmico adquirido do processo experimental e o numericamente simulado para a amostra 2205G25.

Resultado outrora previsto, o modelo apresenta uma configuração sutilmente discrepante para com os resultados experimentais, quando se comparados com os obtidos nas amostras com um aporte térmico menor. Diante deste fato, ainda assim as diferenças absolutas relativas ficam abaixo de 7\% para as temperaturas de pico apresentadas na tabela 7.10. O termopar 3, na maioria dos casos das amostras com aporte térmico de $2,5 \mathrm{~kJ} / \mathrm{mm}$, fica com valores subestimados de temperatura de pico assim como sua taxa de resfriamento. Nestes casos, analisando os resultados obtidos, verificou-se que a temperatura obtida para o termopar 3 estava relacionada a um nó da malha de elementos finitos não equivalente à posição espacial real do mesmo. Fato recorrente em outras amostras, mas que não prejudicam os resultados obtidos.

Tabela 7.10: Diferenças absolutas entre as temperaturas de pico registradas no experimento e encontradas na simulação numérica para a amostra 2205G25.

\begin{tabular}{|c|c|c|c|c|c|}
\hline 2205G25 & TP-1 & TP-2 & TP-3 & TP-4 & TP-5 \\
\hline EXP & 1135,51 & 1068,59 & 709,70 & 463,61 & 325,90 \\
\hline SIM & 1119,6 & 1019,6 & 664,1 & 441,8 & 338,1 \\
\hline DIF (\%) & 1,40 & 4,58 & 6,43 & 4,71 & 3,61 \\
\hline
\end{tabular}


A penetração da região fundida para esta amostra foi de 2,1mm, medida através de análise macrográfica, e na simulação foi encontrado um valor de 2,5mm, constatando um erro relativo de 16\%, conforme figura 7.22. Como descrito anteriormente, esse erro tenderia a aumentar, uma vez aplicado um aporte térmico maior e maiores gradientes se desenvolverem nessas amostras, assim como a convecção térmica, por mais que esteja melhorada nessas análises, ainda se usa de valores discretos para descrevê-la. Também é mostrado a altura do cordão de solda para essa amostra, baseado na análise metalográfica.

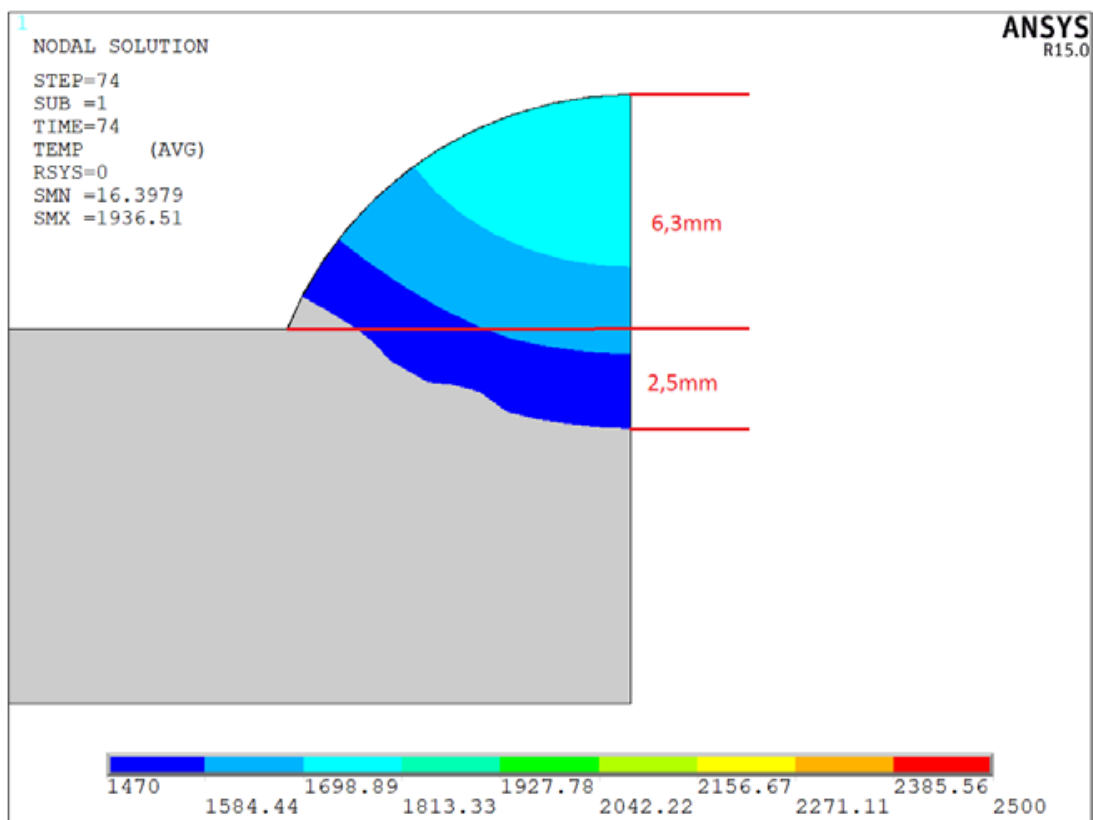

Figura 7.22: Imagem da ZF da amostra 2205G25.

\section{Amostra 2304G25}

De forma análoga, utilizando os mesmos parâmetros geométricos do modelo da fonte de calor, os ciclos térmicos obtidos para a amostra $2304 \mathrm{G} 25$ são mostrados na figura 7.23. Os valores aqui exibidos, parecem se ajustar de maneira melhor do que para a amostra anterior, provavelmente por conta dos pontos onde as temperaturas são obtidas, estarem melhor descritos para essa amostra. 


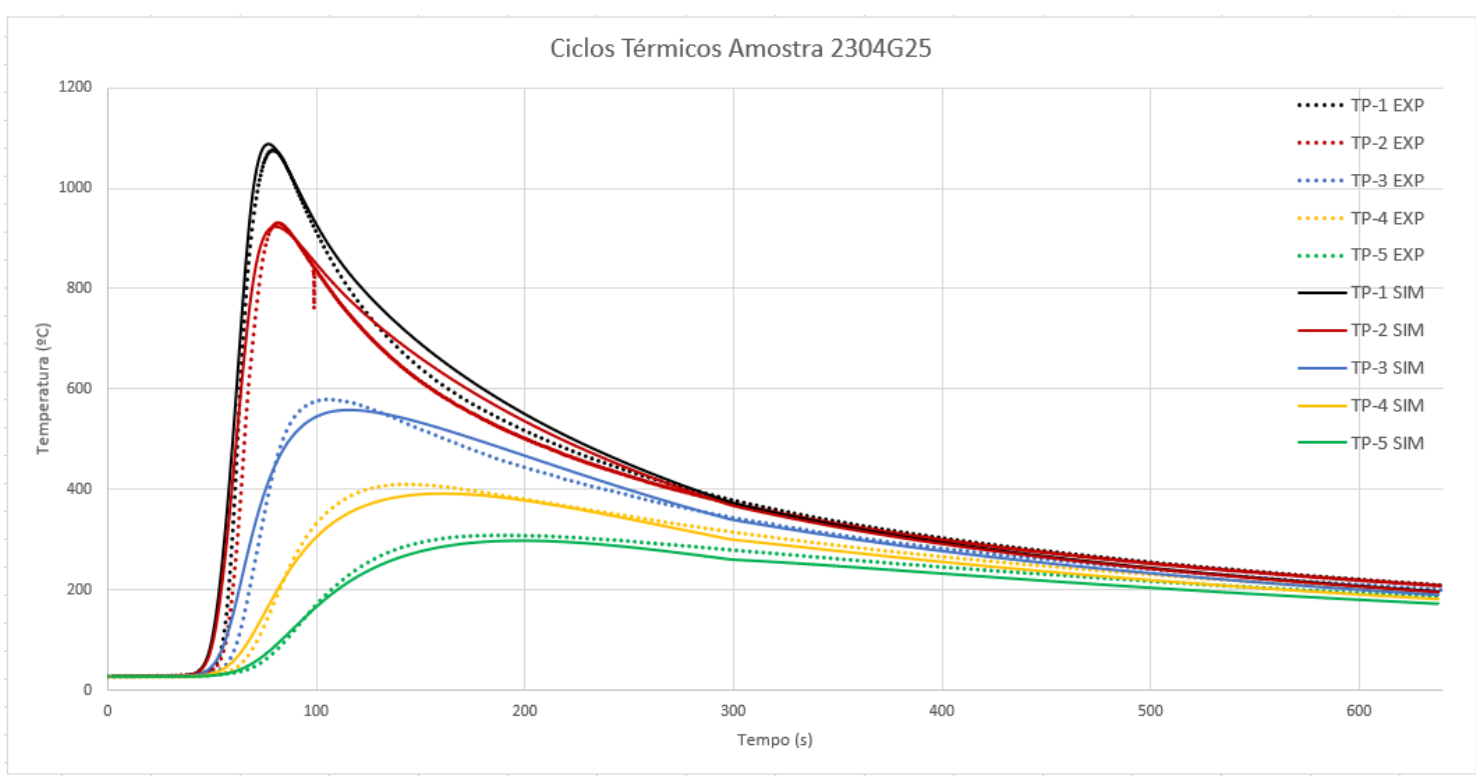

Figura 7.23: Comparação entre o ciclo térmico adquirido do processo experimental e o numericamente simulado para a amostra 2304G25.

A tabela 7.11 mostra o maior erro relativo às temperaturas de pico encontradas para os 5 termopares acoplados à chapa, como sendo um erro menor do que $5 \%$, para o termopar 4 .

Tabela 7.11: Diferenças absolutas entre as temperaturas de pico registradas no experimento e encontradas na simulação numérica para a amostra 2304G25.

\begin{tabular}{|c|c|c|c|c|c|}
\hline 2304G25 & TP-1 & TP-2 & TP-3 & TP-4 & TP-5 \\
\hline EXP & 1076,19 & 931,21 & 579,419 & 410,37 & 309,03 \\
\hline SIM & 1088 & 923,4 & 558,4 & 392 & 298,3 \\
\hline DIF (\%) & 1,09 & 0,84 & 3,63 & 4,48 & 3,47 \\
\hline
\end{tabular}

A penetração da linha de fusão para esta amostra foi de 2,4mm, medida através de análise macrográfica. $\mathrm{O}$ valor encontrado para a mesma medida na simulação numérica foi de 2,6mm, sendo a diferença absoluta entre os valores de 7,69\%, conforme figura 7.24. Também é mostrada a altura do cordão de solda para essa amostra, baseado na análise metalográfica. 


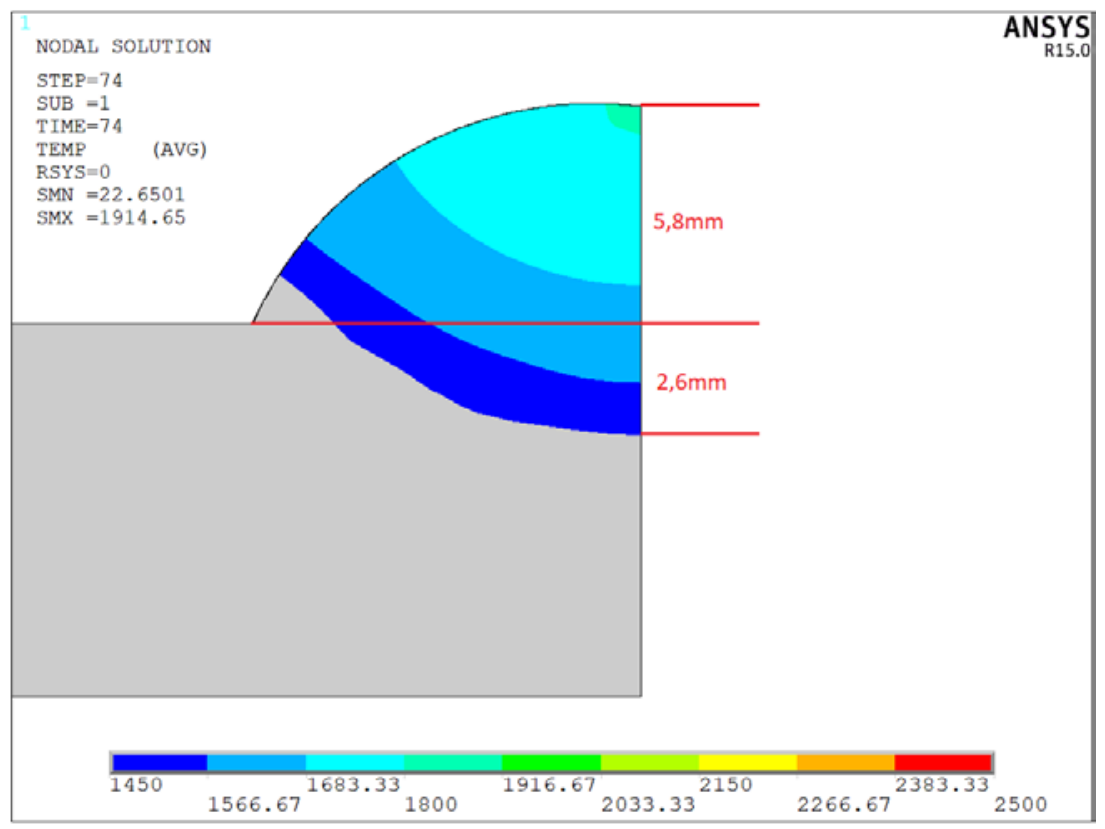

Figura 7.24: Imagem da ZF da amostra 2304G25.

\section{Amostra 2205P25}

Apesar dessas próximas duas amostras apresentarem "efeito de borda" (discutido previamente), os resultados serão brevemente mostrados, a fim de explicar uma condição particular.

Os ciclos térmicos obtidos para essa amostra, exibidos na figura 7.25, apresentam uma boa concordância.

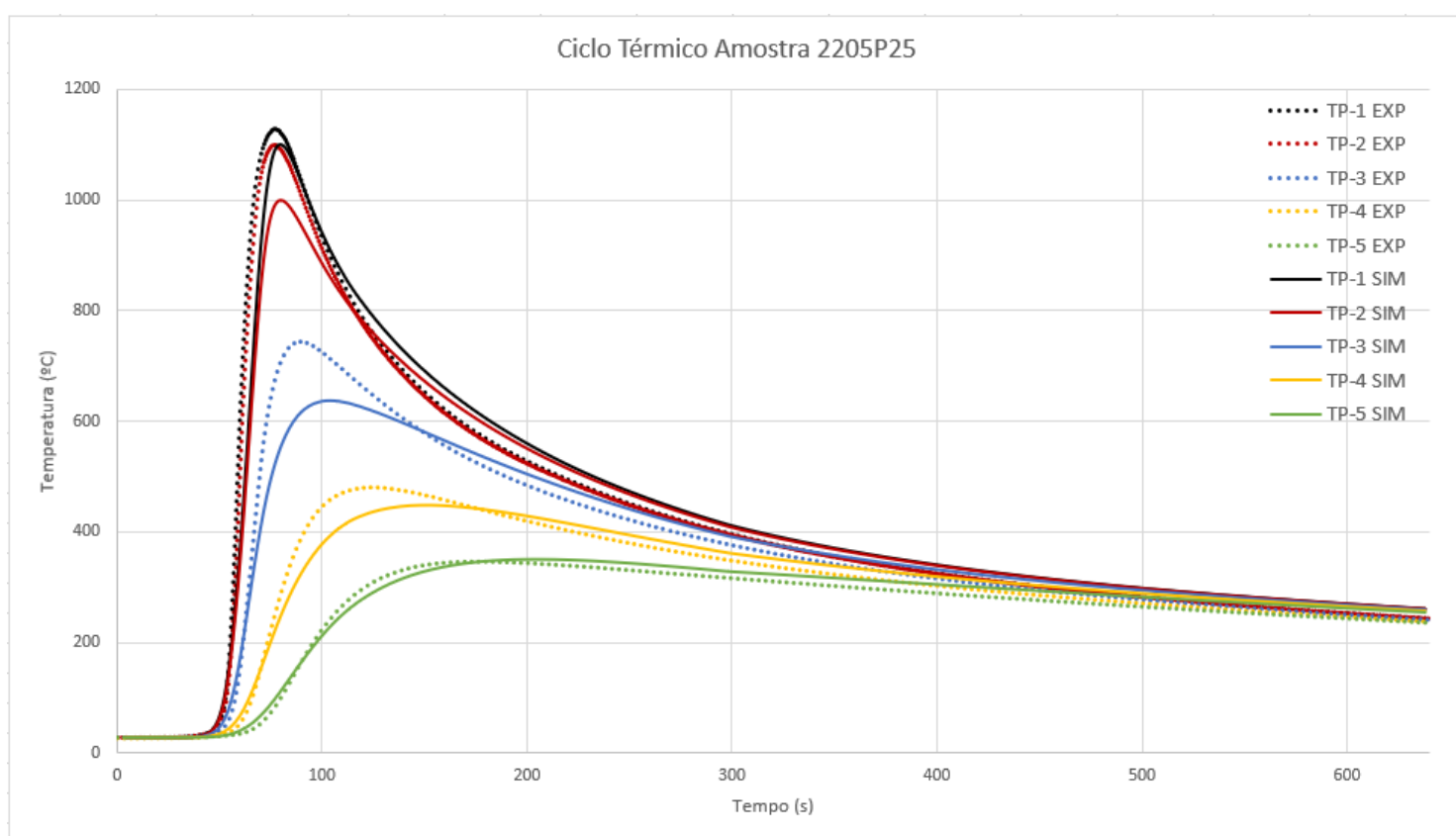

Figura 7.25: Comparação entre o ciclo térmico adquirido do processo experimental e o numericamente simulado para a amostra 2205P25. 
A tabela 7.12 mostra os erros relativos às temperaturas de pico encontradas para os 5 termopares, onde apesar de visualmente no gráfico as diferenças parecem maiores, a maior delas fica abaixo dos 15\%, para o termopar 3.

Tabela 7.12: Diferenças absolutas entre as temperaturas de pico registradas no experimento e encontradas na simulação numérica para a amostra 2205P25.

\begin{tabular}{|c|c|c|c|c|c|}
\hline 2205P25 & TP-1 & TP-2 & TP-3 & TP-4 & TP-5 \\
\hline EXP & 1129,10 & 1100,54 & 743,97 & 480,49 & 346,36 \\
\hline SIM & 1100,6 & 999,7 & 637,3 & 448,3 & 350,4 \\
\hline DIF (\%) & 2,52 & 9,16 & 14,34 & 6,70 & 1,15 \\
\hline
\end{tabular}

A condição dita acima remete à profundidade de penetração da linha de fusão para esta e a próxima amostra. Para esta amostra foi de 1,5mm, medida através de análise macrográfica. Esta penetração da região fundida para a atual e próxima amostras, não acompanha o que aconteceu para as amostras que foram soldadas com o aporte térmico de $1,5 \mathrm{~kJ} / \mathrm{mm}$, onde todas tiveram praticamente a mesma penetração. Seguiu-se um valor destoante para esse perfil, o que já era um indicativo do efeito de borda, e foi comprovado pelas simulações na seção 7.2.1.

O valor encontrado para esta grandeza nas simulações numéricas não foi capaz de reproduzir o esperado e encontrado de maneira experimental, sendo o valor de 2,3mm, exibido na figura 7,26, o que denota uma diferença de $34,78 \%$. O efeito de borda então não é devidamente obtido pelo processo de simulação numérica apresentado neste trabalho, provavelmente devido ao problema em se adequar os valores do processo de convecção térmica na simulação, discutidos também na seção 7.2.1. 


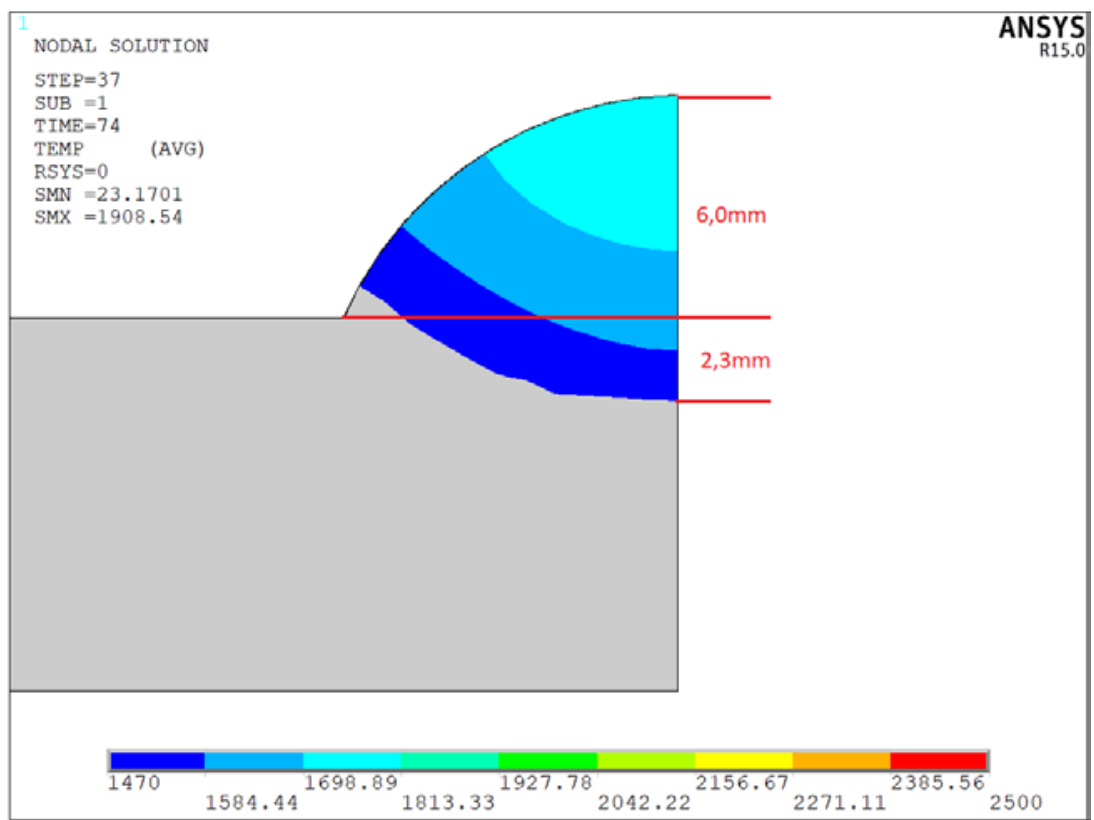

Figura 7.26: Imagem da ZF da amostra 2205P25.

\section{Amostra 2304P25}

Exatamente o mesmo fato relatado para a amostra anterior, aqui também é encontrado, onde utilizando os devidos valores geométricos para a fonte de calor, obtemos os ciclos térmicos mostrados na figura 7.27, e as diferenças na tabela 7.13 .

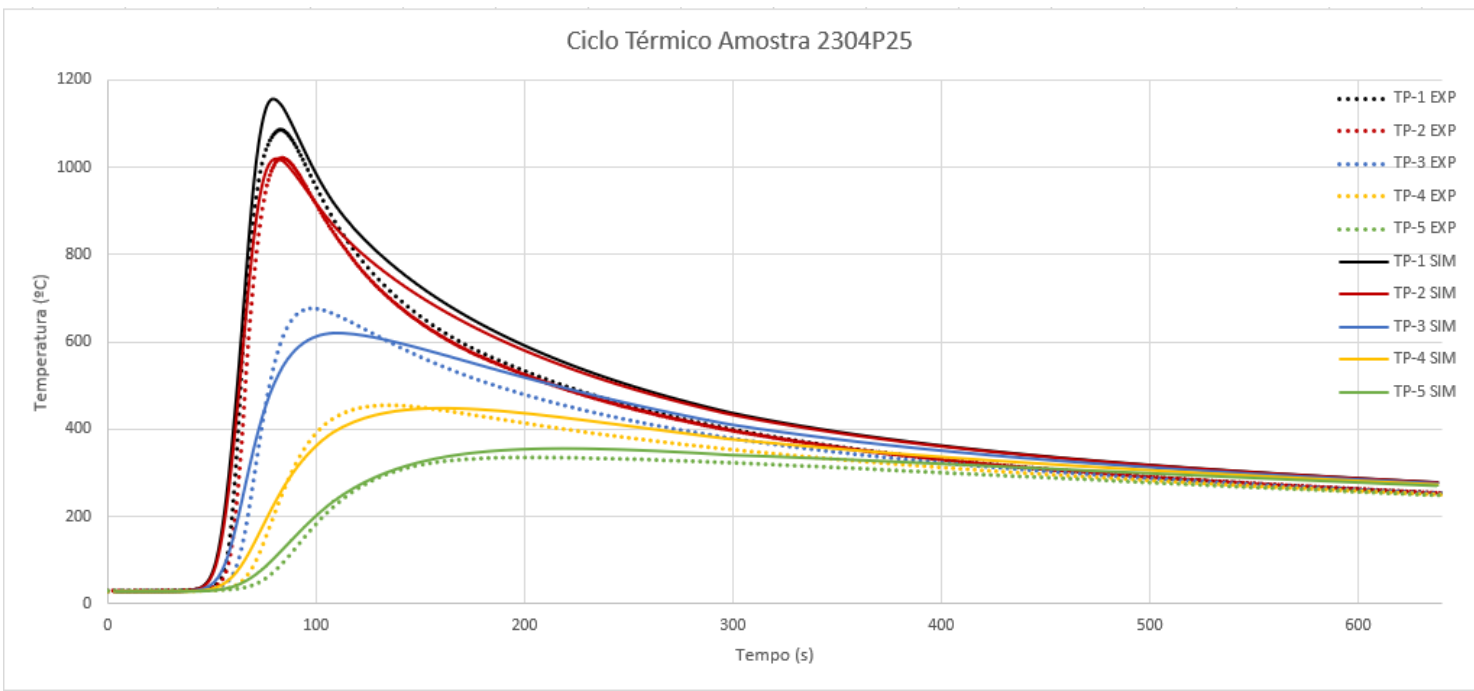

Figura 7.27: Comparação entre o ciclo térmico adquirido do processo experimental e o numericamente simulado para a amostra 2304P25. 
As curvas se ajustam relativamente bem às experimentais e os valores máximos dos erros relativos ficam abaixo de 9\%, sendo o maior deles encontrado também para o termopar 3.

Tabela 7.13: Diferenças absolutas entre as temperaturas de pico registradas no experimento e encontradas na simulação numérica para a amostra 2304P25.

\begin{tabular}{|c|c|c|c|c|c|}
\hline 2304P25 & TP-1 & TP-2 & TP-3 & TP-4 & TP-5 \\
\hline EXP & 1086,55 & 1021,90 & 676,89 & 454,99 & 335,52 \\
\hline SIM & 1156,3 & 1019,2 & 620,2 & 448 & 355,7 \\
\hline DIF (\%) & 6,03 & 0,26 & 8,38 & 1,54 & 5,67 \\
\hline
\end{tabular}

Novamente o modelo não conseguiu descrever o efeito de borda, apresentado para essa amostra, de maneira adequada, onde o perfil de penetração da linha de fusão medido através de análise macrográfica revelou um valor de $1,20 \mathrm{~mm}$. Como mostrado na figura 7.28, no processo numérico, o valor obtido foi de $2,6 \mathrm{~mm}$, gerando um erro relativo de $53,84 \%$ para esta amostra.

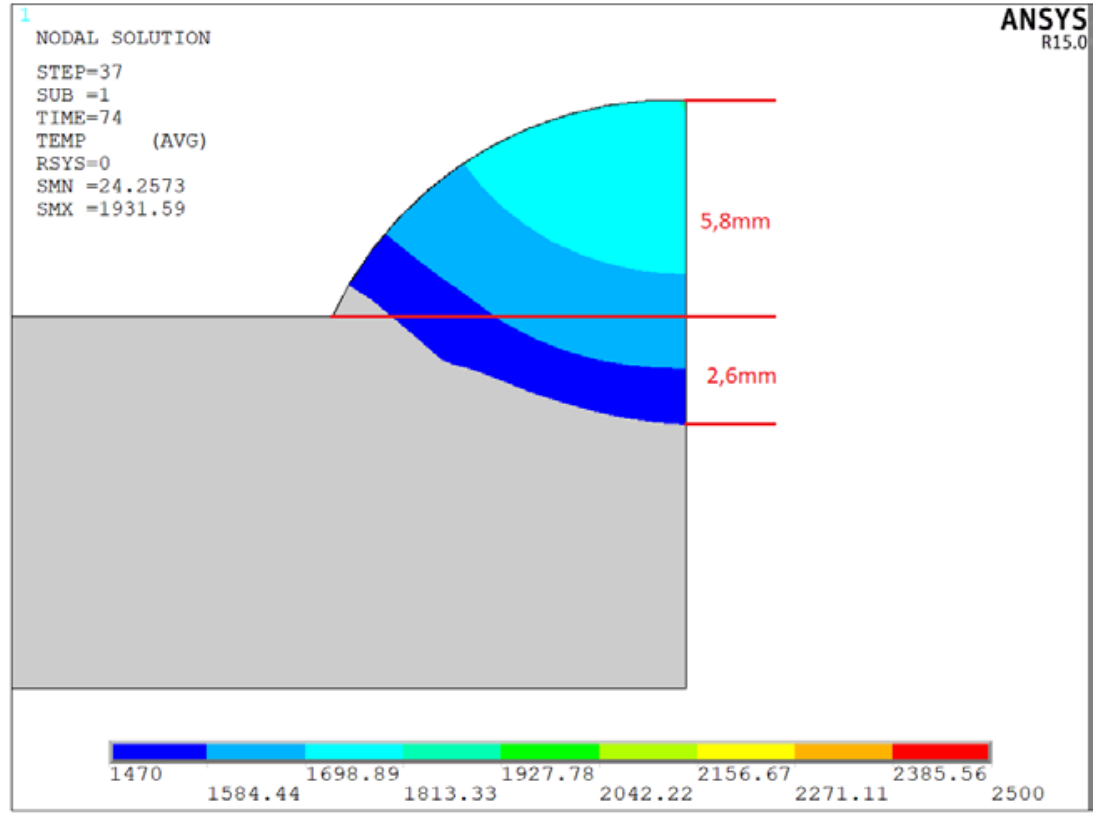

Figura 7.28: Imagem da ZF da amostra 2304P25. 


\section{3}

\section{Ciclos Térmicos Simulados x Microestrutura}

Através dos resultados obtidos na fase anterior, verifica-se a boa concordância com os dados experimentais na etapa de validação do modelo, confirmando uma adequada calibração para o modelo numérico adotado. Com o objetivo de se obter os ciclos térmicos em posições diferentes daquelas onde existiam os termopares, o modelo foi calibrado, sendo assim possível a realização deste procedimento.

Fazendo uso, desta maneira, do sentido em se lograr um modelo numérico devidamente calibrado, agora podendo ser usado para outras aplicações. Sendo assim, dados simulados dos ciclos térmicos das amostras foram obtidos na extensão da ZTA, como mostrado na figura 7.29, diretamente na linha central de todas elas, e esses dados puderam assim ser comparados com as imagens feitas por microscopia.

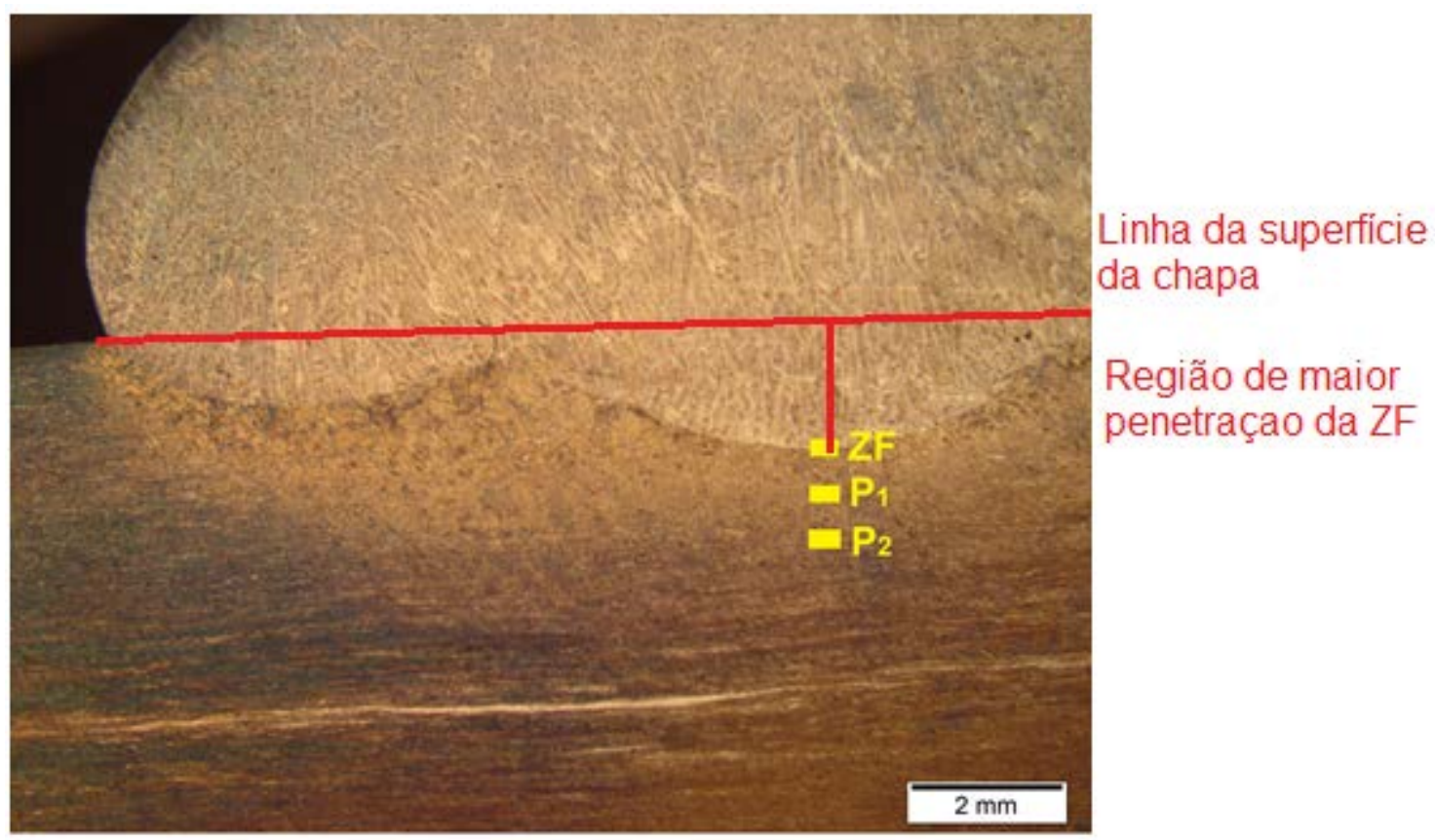

Figura 7.29: Macroscopia ilustrando a posição onde foram obtidos os ciclos térmicos simulados, a fim de serem comparados com a microestrutura encontrada experimentalmente.

Para identificar as temperaturas onde acontece a ferritização dos materiais aqui reportados, são utilizados diagramas de frações de fase obtidos através do software Thermo-Calc. O Thermo-Calc calcula as propriedades termodinâmicas 
das espécies a partir de modelos ajustados mediante a utilização de dados experimentais. Objetiva-se também usar estes diagramas para prever as prováveis transformações de fase que ocorrem nas temperaturas atingidas em cada amostra. Os diagramas foram obtidos de uma tese de doutoramento da autora que se utilizou dos mesmos materiais aqui estudados, reportados em (LUENGAS, 2017), e mostrados na figura 7.30.

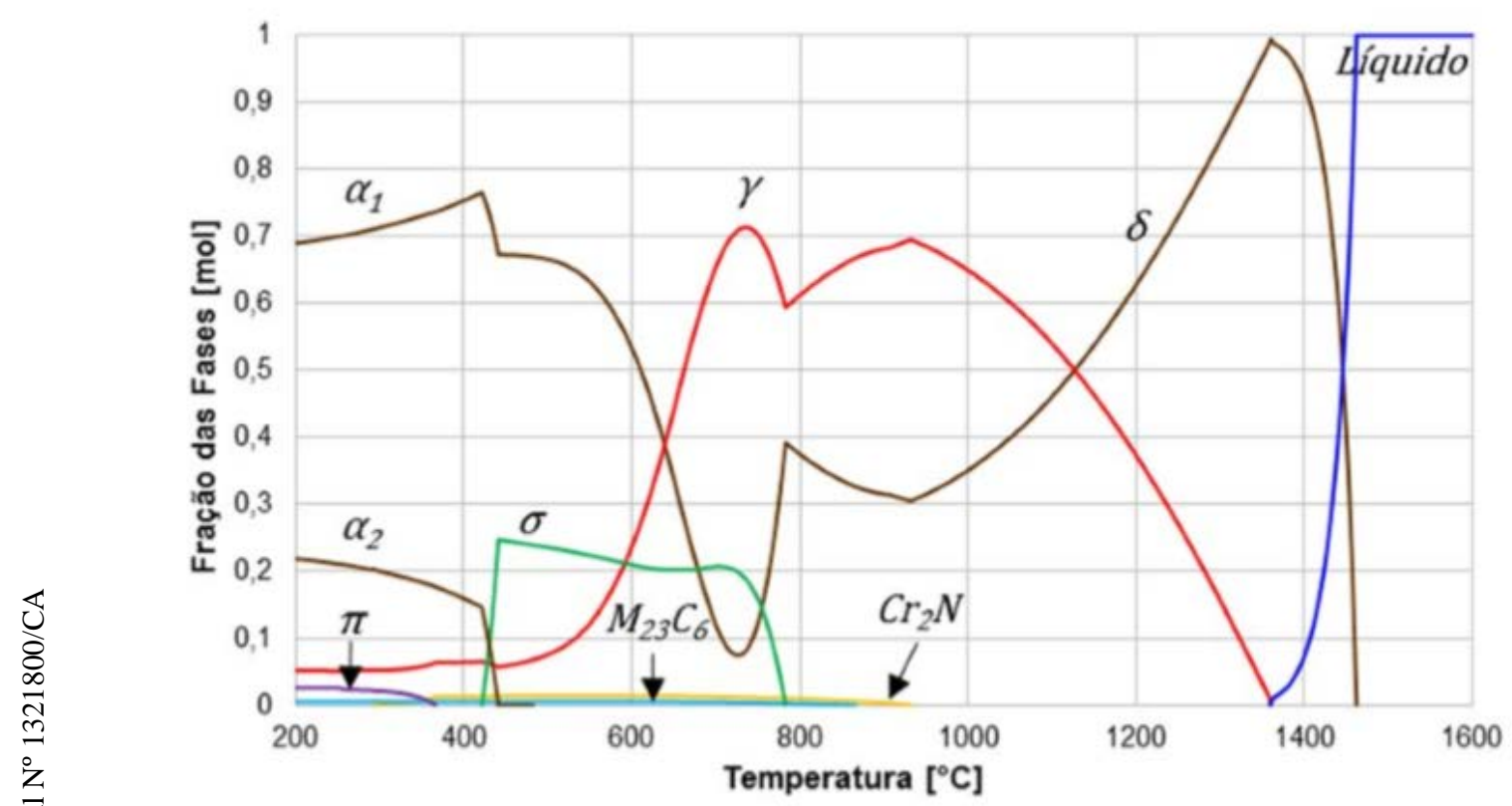

Frações de fase calculadas para o aço inoxidável lean duplex UNS S32304 (2304).

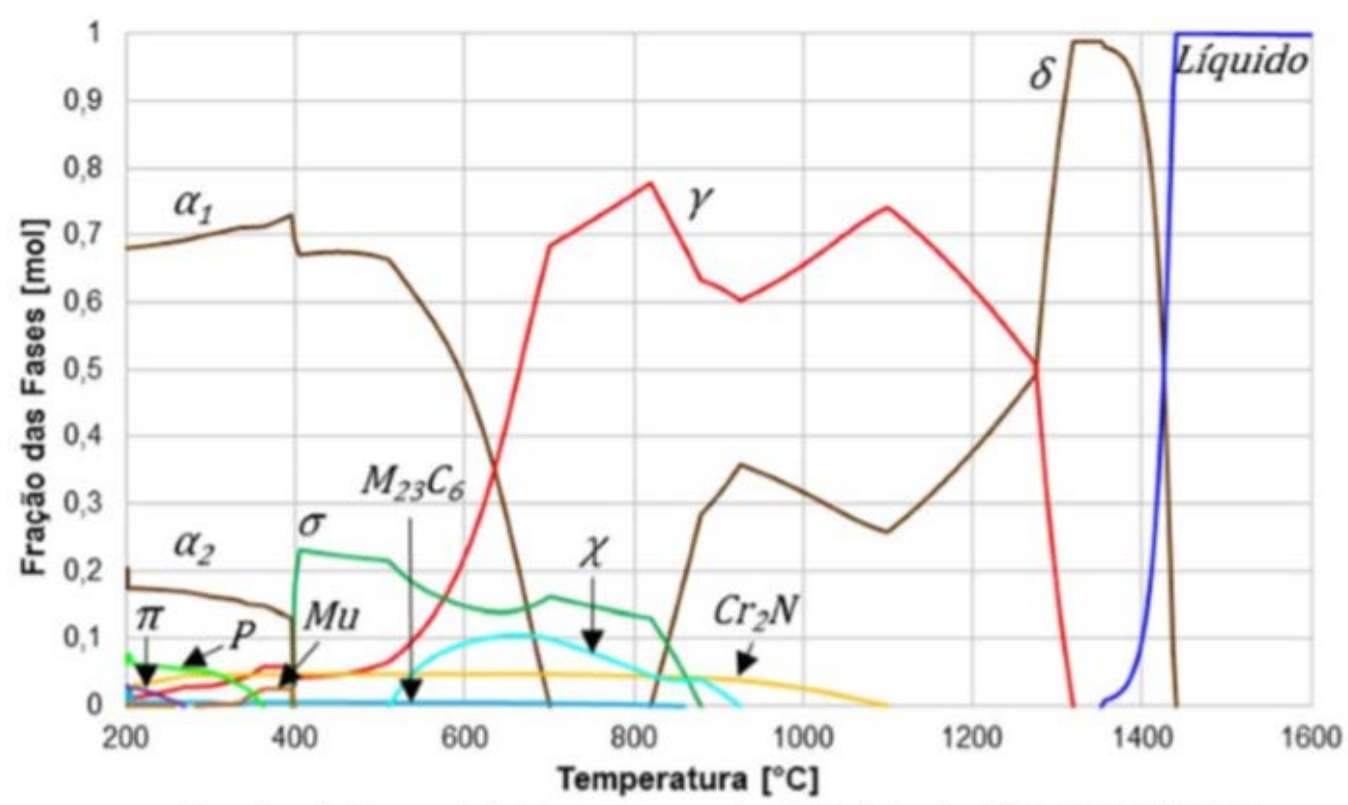

Frações de fase calculadas para o aço inoxidável duplex UNS S32205 (2205).

Figura 7.30: Diagramas obtidos através do software "thermocalc" para os dois aços estudados no presente trabalho, indicando em função da temperatura as fases que estariam presentes em condições de equilíbrio (LUENGAS, 2017). 
Segundo a autora, os diagramas de fases dos AIDs em questão, foram obtidos utilizando o Thermo-Calc Software 4.1 com a base de dados TCFE3. A base de dados TCFE3 é uma base de dados termodinâmica aplicável para diferentes tipos de aços e ligas de ferro com um mínimo de 50\% de ferro em massa. É usada para prever as temperaturas de liquidus e solidus para diferentes tipos de aços. Além de prever as fases que se encontram em equilíbrio no estado sólido.

A tabela 1.14 mostra as temperaturas de equilíbrio das fases ferrita e austenita, assim como a faixa de temperatura de ferritização. Onde, apesar do aço Lean Duplex 2304 apresentar uma temperatura de equilíbrio das fases menor do que o 2205, a faixa de temperatura na qual acontece a ferritização completa do material, acaba sendo maior.

Tabela 7.14: Temperaturas do balance de fases Austenita-Ferrita próximo 1:1 e temperatura de completa ferritização (LUENGAS, 2017).

\begin{tabular}{|c|c|c|}
\hline AID & $\begin{array}{c}\text { Temperatura de Equilíbrio 1:1 de } \\
\text { Ferrita-Austenita }\left({ }^{\circ} \mathrm{C}\right)\end{array}$ & $\begin{array}{c}\text { Temperatura de Ferritização } \\
\text { Completa }\left({ }^{\circ} \mathbf{C}\right)\end{array}$ \\
\hline UNS S32304 & 1126 & $1329-1359$ \\
\hline UNS S32205 & 1275 & $1319-1352$ \\
\hline
\end{tabular}

Para esta etapa seguinte, apenas as amostras que não apresentaram efeito de borda, ou seja, as de geometria 150×300x10mm serão consideradas.

\subsection{1}

\section{Amostras Aporte Térmico Maior - 2,5kJ/mm}

\section{Amostra 2205G25}

Para esta primeira amostra a ser analisada, a figura 7.31exibe os ciclos térmicos obtidos em 3 pontos diferentes, o primeiro deles na linha da zona fundida, o segundo a uma distância de $0,5 \mathrm{~mm}$, e o terceiro a $1 \mathrm{~mm}$ de distância do primeiro, sendo todos lineares em direção à superfície inferior da chapa.

Um parâmetro utilizado em soldagem para avaliar as transformações microestruturais que ocorrem é o tempo de resfriamento na faixa entre 1200- 
$800^{\circ} \mathrm{C}\left(\Delta t_{12-8}\right)$, o qual corresponde ao intervalo de temperatura de maior relevância para os AID’s, por ser esta, a faixa de temperatura em que ocorre a precipitação e coalescimento da austenita na matriz ferrítica (Vasconcellos, 2008; Londoño, 1997). Verifica-se que as taxas de resfriamento dos 3 pontos abordados são muito próximas, e medindo os tempos de resfriamento para cada um dos pontos no intervalo de 1200 a $800^{\circ} \mathrm{C}$, temos:

Para a Zona Fundida: $\Delta t_{12-8}=43,5 s\left(\mathrm{~T}_{\text {máx }}=1470^{\circ} \mathrm{C}\right)$

Para o ponto afastado 0,5mm: $\Delta t_{12-8}=45 s\left(\mathrm{~T}_{\text {máx }}=1400^{\circ} \mathrm{C}\right)$

Para o ponto afastado $1 \mathrm{~mm}: \Delta t_{12-8}=47 \mathrm{~s}\left(\mathrm{~T}_{\text {máx }}=1340^{\circ} \mathrm{C}\right)$

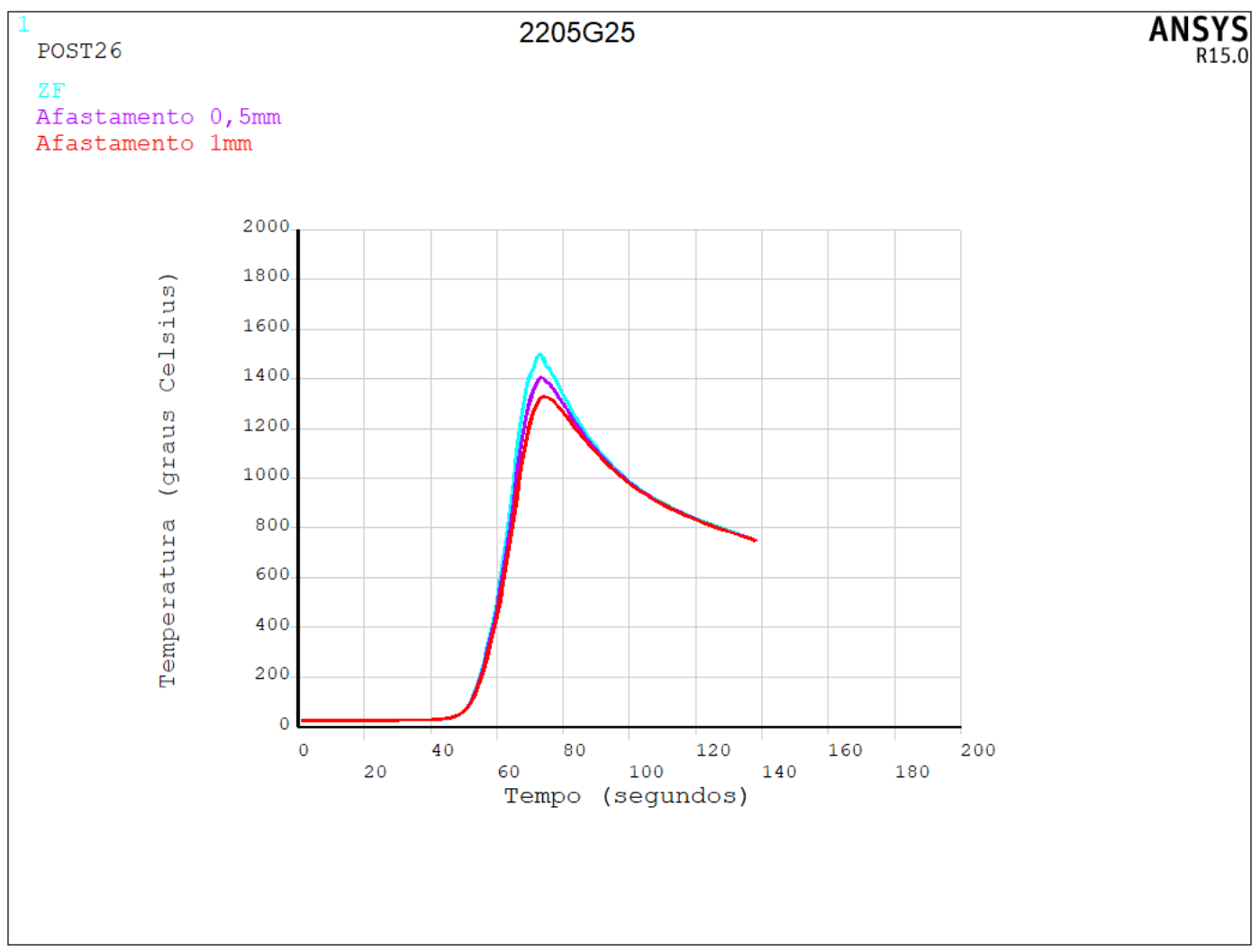

Figura 7.31: Ciclos térmicos simulados para a amostra 2205G25.

A temperatura, a $1 \mathrm{~mm}$ de afastamento da linha de fusão dessa amostra, chegou a $1340^{\circ} \mathrm{C}$, ficando assim na faixa da temperatura de ferritização (a partir de $1300^{\circ} \mathrm{C}$ ), mas o tempo de resfriamento foi bastante elevado, permitindo a reforma da austenita, que previamente havia se dissolvido na matriz ferrítica. A figura 7.32 mostra que a partir de $1 \mathrm{~mm}$ de distância da linha de fusão, a morfologia da microestrutura se torna mais homogênea. A mesma imagem revela 
o já esperado, com uma ZTATE adjacente à linha de fusão, com grãos grandes de ferrita, e uma ZTATB, mais afastada dessa região.

A quantificação de fase, foi feita através de análise de imagens, com o software "Fiji” e mostrou os seguintes resultados, para a condição de como recebido:

_52\% de ferrita;

_48\% de austenita.

mostrando uma fração de fase próxima da proporção esperada para os aços inoxidáveis duplex (50:50).

Para a amostra em questão, a proporção de fases resultante foi:

_para o primeiro 0,5mm, uma ZTATE, foi determinado 51\% de ferrita;

_para o segundo 0,5mm, ZTATB, foi determinado 48\% de ferrita.

Nas amostras soldadas com o aporte térmico de $2,5 \mathrm{~kJ} / \mathrm{mm}$, as frações de fase da austenita são superiores àquelas de menor aporte empregado, uma vez que o tempo $\left(\Delta t_{12-8}\right)$ é maior, contribuindo assim para a reforma da austenita, resultando em um balanço mais homogêneo das fases. Da mesma forma, com o aumento do aporte térmico, o tamanho de grão ferrítico tende a aumentar, evidenciado para as amostras aqui exibidas. Como a velocidade de resfriamento obtida foi menor (do que a amostra de mesmo material com aporte de $1,5 \mathrm{~kJ} / \mathrm{mm}$ ), a austenita nucleada nos contornos de grão da ferrita, obteve um aspecto contínuo.

O resultado microestrutural não foi estritamente contabilizado no modelo, numérico, uma vez que este não considera transformação de fases. Mas o mesmo apresenta uma boa previsão das temperaturas de pico e principalmente das taxas de resfriamento envolvidas no processo de soldagem, dados que levam a se obter uma estimativa da microestrutura. 


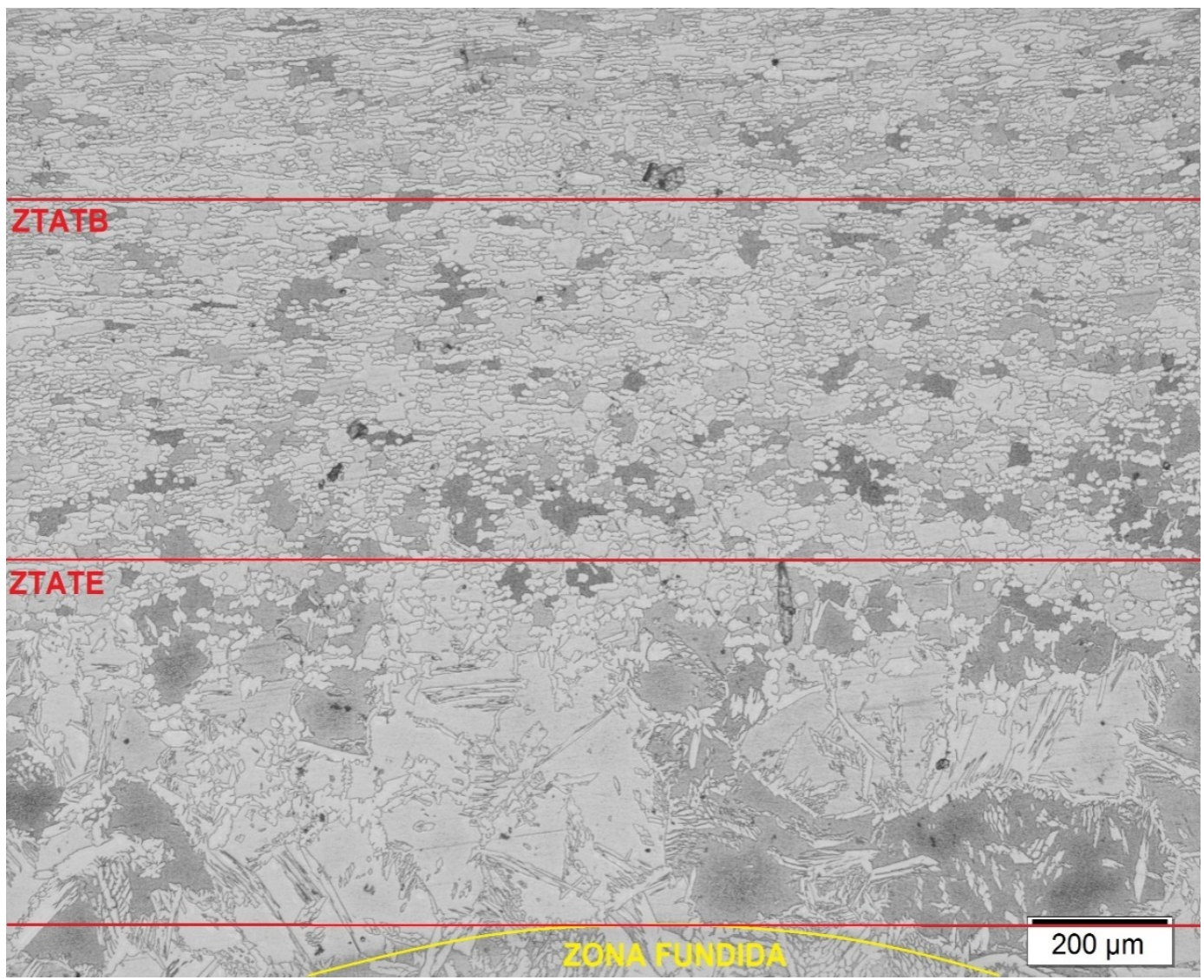

Figura 7.32: Imagens obtidas por microscopia da amostra 2205G25. Superior com um aumento de 100x, inferior com um aumento de 200x.

\section{Amostra 2304G25}

De maneira análoga à anterior, a figura 7.33 exibe os ciclos térmicos obtidos em 3 pontos diferentes, o primeiro deles situado sob a linha da zona fundida, o segundo a uma distância de $0,5 \mathrm{~mm}$, e o terceiro a $1 \mathrm{~mm}$ de distância do primeiro. Foram obtidos os perfis de temperatura exatamente da mesma maneira que da amostra anterior, uma vez que a malha apresenta a mesma característica de discretização.

Novamente, como aconteceu com a amostra anterior de mesmo aporte térmico, as taxas de resfriamento dos 3 pontos abordados são muito próximas, e medindo os tempos de resfriamento para cada um dos pontos no intervalo de 1200 a $800^{\circ} \mathrm{C}$, temos os seguintes valores:

Para a Zona Fundida: $\Delta t_{12-8}=44 s\left(\mathrm{~T}_{\text {máx }}=1470^{\circ} \mathrm{C}\right)$

Para o ponto afastado 0,5mm: $\Delta t_{12-8}=45 s\left(\mathrm{~T}_{\text {máx }}=1430^{\circ} \mathrm{C}\right)$

Para o ponto afastado $1 \mathrm{~mm}: \Delta t_{12-8}=46,5 s\left(\mathrm{~T}_{\text {máx }}=1390^{\circ} \mathrm{C}\right)$ 


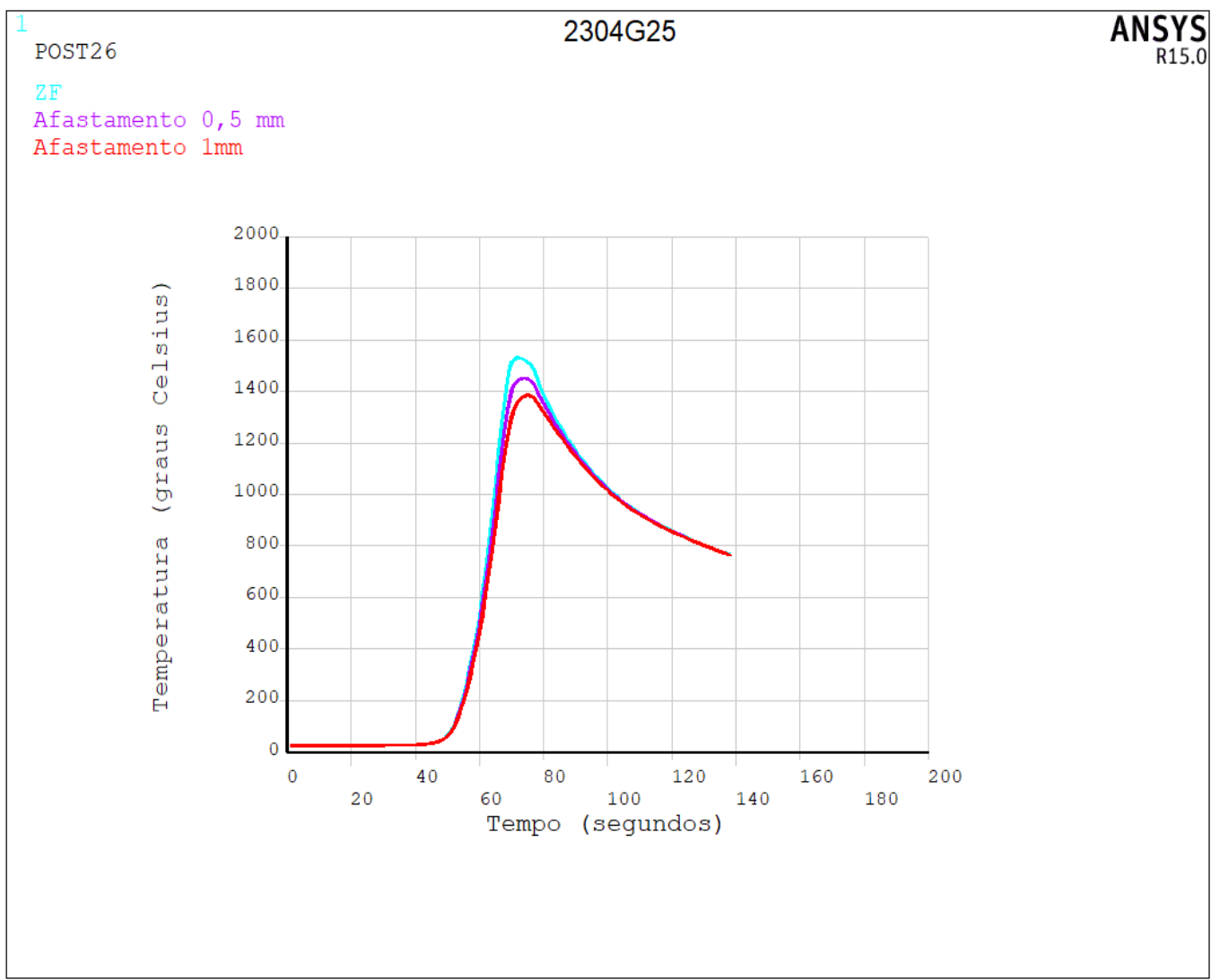

Figura 7.33: Ciclos térmicos simulados para a amostra 2304G25.

A quantificação de fase, foi feita através de processamento de imagens, análogo a todas as amostras e mostrou os seguintes resultados, para a condição de como recebido:

_60\% de ferrita;

_ $40 \%$ de austenita.

sendo assim, o aço lean duplex, na condição de como recebido, já apresentava fração maior de ferrita do que de austenita.

Em se tratando da amostra 2304G25, a quantificação de fase, (FIG. 7.34) mostrou os seguintes resultados:

_para o primeiro 0,5mm, uma ZTATE, foi determinado 66\% de ferrita;

_para o segundo 0,5mm, ZTATB, foi determinado 57\% de ferrita. 


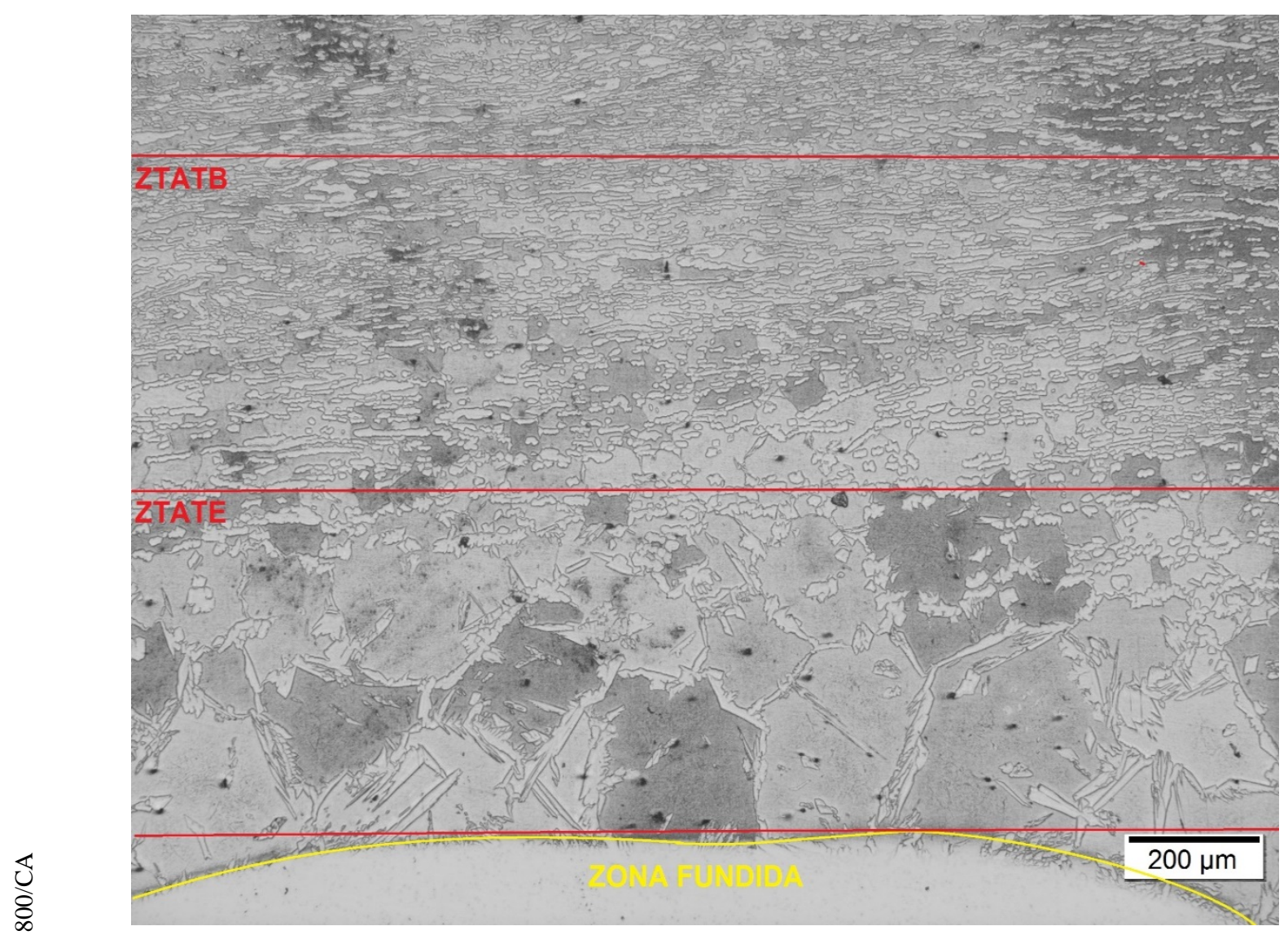

Figura 7.34: Imagens obtidas por microscopia da amostra 2304G25. Superior com um aumento de 100x, inferior com um aumento de 200x.

O aço inoxidável lean duplex 2304 apresenta um teor de cromo ligeiramente maior do que o aço duplex 2205. Sendo o cromo um estabilizador da ferrita, existe, com isso, a tendência dessa fase ser favorecida para este aço. Este maior conteúdo de ferrita na ZTA do aço lean duplex não é exclusivamente devido ao maior teor de Cr neste aço. Embora o cromo seja um elemento estabilizador da ferrita assim também é o molibdênio, que está presente em menor teor neste aço, em comparação ao 2205. O maior conteúdo de ferrita na ZTA do aço lean duplex pode ser associado ao fato de que na soldagem, o tempo na temperatura de pico foi suficiente para atingir a ferritização completa, uma vez que as temperaturas aqui atingidas, foram maiores do que as para o aço 2205. Assim a microestrutura apresentou um tamanho de grão de ferrita maior do que aquele encontrado no aço duplex. 


\subsection{2}

\section{Amostras Aporte Térmico Menor - 1,5kJ/mm}

\section{Amostra 2205G15}

Para as amostras que foram soldadas com o aporte térmico de 1,5kJ/mm e que possuem geometria 150x300x10mm, onde a primeira a ser analisada é a do material 2205, os ciclos térmicos obtidos através da simulação numérica, está apresentado a seguir, na figura 7.35.

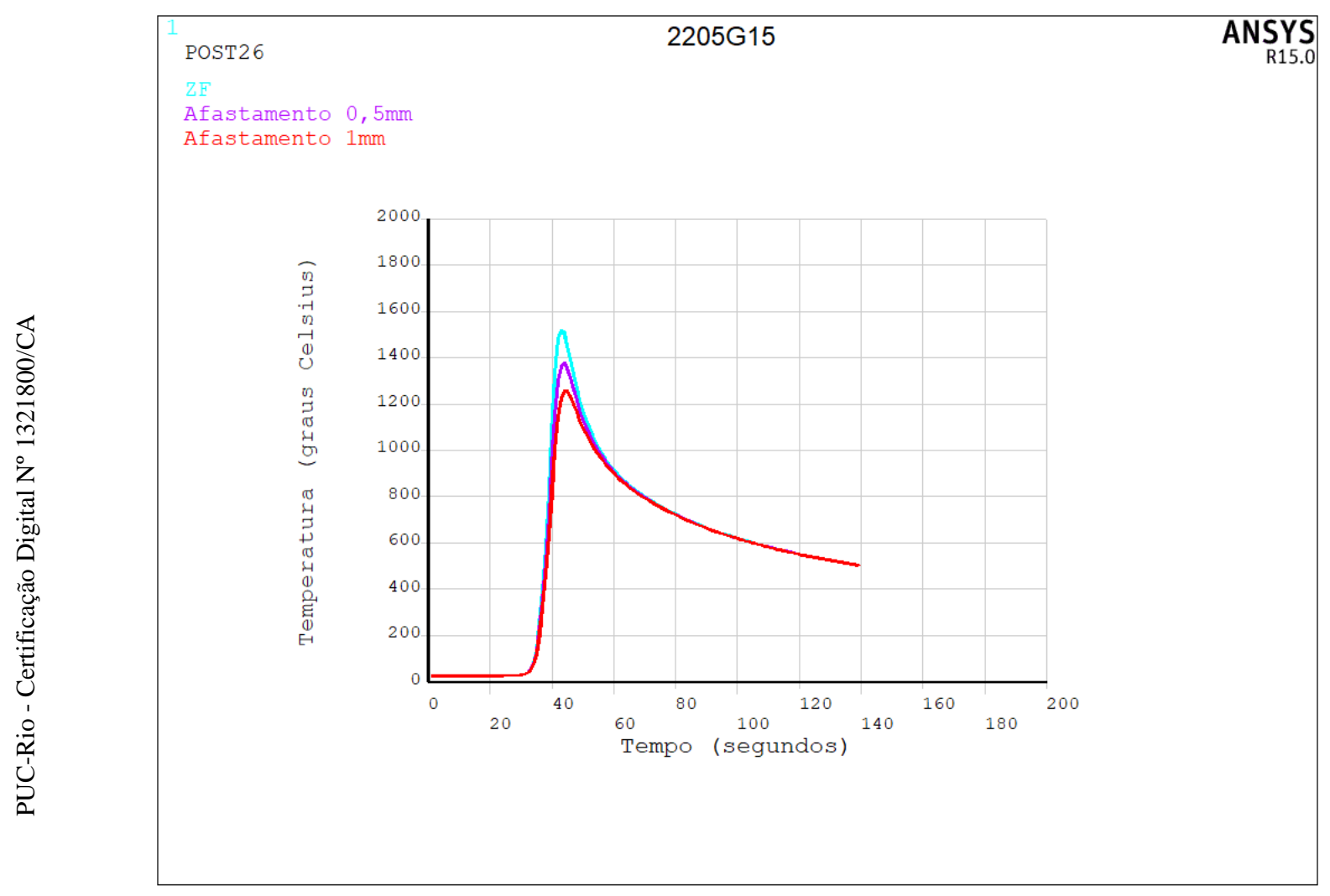

Figura 7.35: Ciclos térmicos simulados para a amostra 2205G15.

Mantendo a configuração admitida para as amostras anteriores, de maior aporte térmico, fica, para este caso, difícil de identificar quaisquer valores pelo gráfico. Então, de maneira a se adequar ao intervalo de tempo, para o caso das amostras soldadas com aporte térmico de $1,5 \mathrm{~kJ} / \mathrm{mm}$, esse intervalo foi restringido para valores até 80s, identificadas na figura 7.36. Uma outra questão prévia, ao analisar a figura 7.37, decorre do fato da extensão da ZTA ser menor para essas amostras (de menor aporte), então o intervalo dos pontos onde são coletados os valores para os ciclos térmicos será reduzido para 0,25mm de distância, um do 
outro. A menor extensão da ZTA, nessa amostra de menor aporte, pode ser definida pelo gráfico mostrado na figura 7.35, sabendo que a temperatura distante 0,5mm da linha de fusão é equiparável à temperatura distante $1,0 \mathrm{~mm}$ da linha de fusão para a amostra 2205G25.

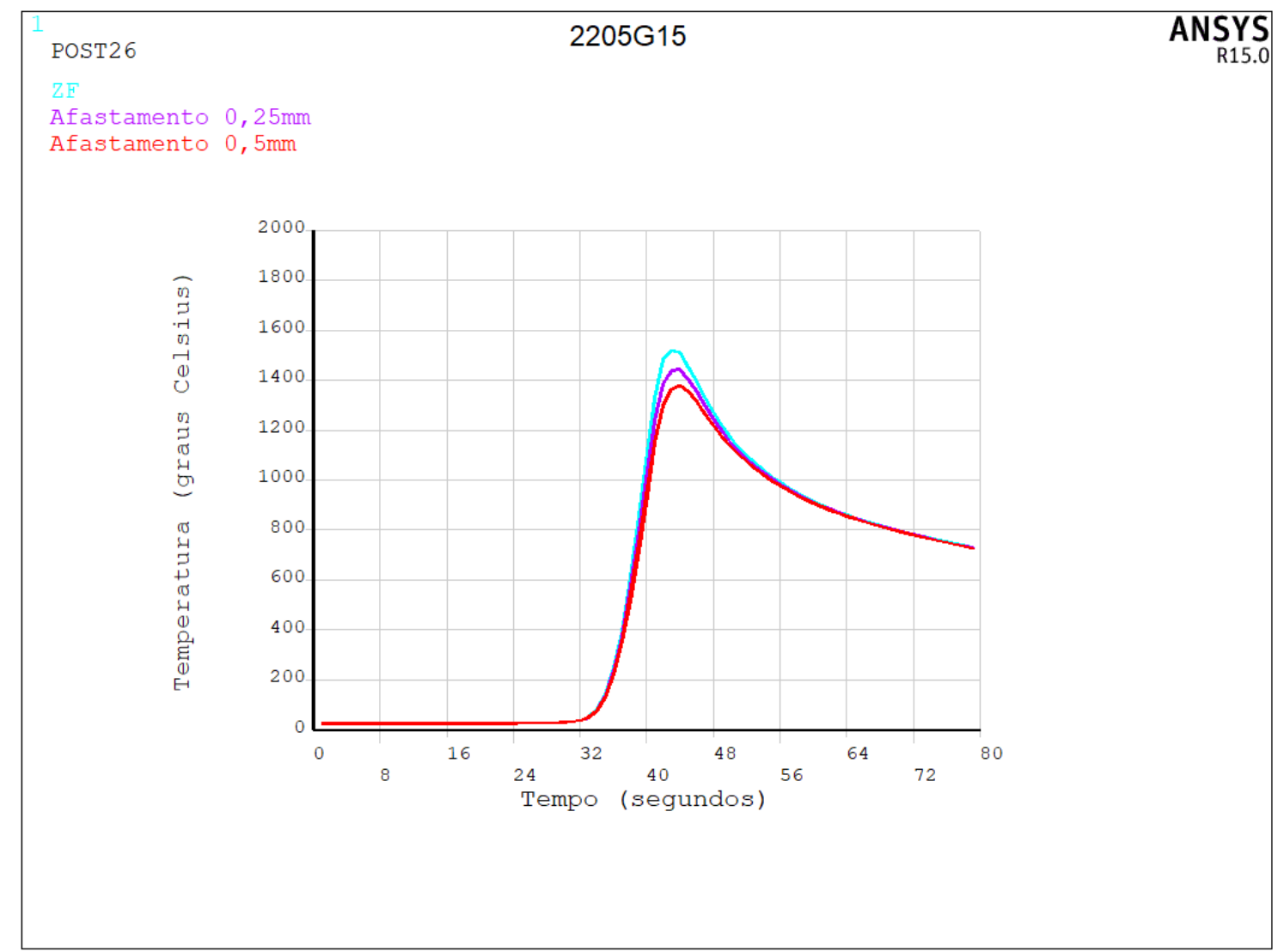

Figura 7.36: Ciclos térmicos simulados para a amostra 2205G15.

Novamente para esses 3 pontos adotados, nota-se que o primeiro deles está exatamente na temperatura de $1470^{\circ} \mathrm{C}$, caracterizado pela linha de fusão. O ponto seguinte dista $0,25 \mathrm{~mm}$ do primeiro, e o segundo agora dista $0,5 \mathrm{~mm}$ do primeiro, e ambos os pontos são colineares ao primeiro, da mesma forma que para as amostras anteriores.

As taxas de resfriamento dos 3 pontos abordados são, mais próximas do que nas amostras anteriores (de maior aporte), e medindo os tempos de resfriamento para cada um dos pontos no intervalo de interesse $\left(1200\right.$ a $\left.800^{\circ} \mathrm{C}\right)$, temos:

Para a Zona Fundida: $\Delta t_{12-8}=19,35 s\left(\mathrm{~T}_{\text {máx }}=1470^{\circ} \mathrm{C}\right)$

Para o ponto afastado $0,25 \mathrm{~mm}: \Delta t_{12-8}=20,05 \mathrm{~s}\left(\mathrm{~T}_{\text {máx }}=1440^{\circ} \mathrm{C}\right)$ 
Para o ponto afastado 0,5mm: $\Delta t_{12-8}=20,65 s\left(\mathrm{~T}_{\text {máx }}=1370^{\circ} \mathrm{C}\right)$

onde, os tempos de resfriamento são menores do que para os aportes térmicos mais elevados, fato já esperado. Para a quantificação de fase, foi realizada da mesma forma que a anterior, através da contagem de fases por imagem (FIG. 7.37), apenas considerando as novas distâncias adotadas e os resultados foram:

_para o primeiro 0,25mm, uma ZTATE, foi determinado 59\% de ferrita; _para o segundo 0,25mm, ZTATB, foi determinado 51\% de ferrita.

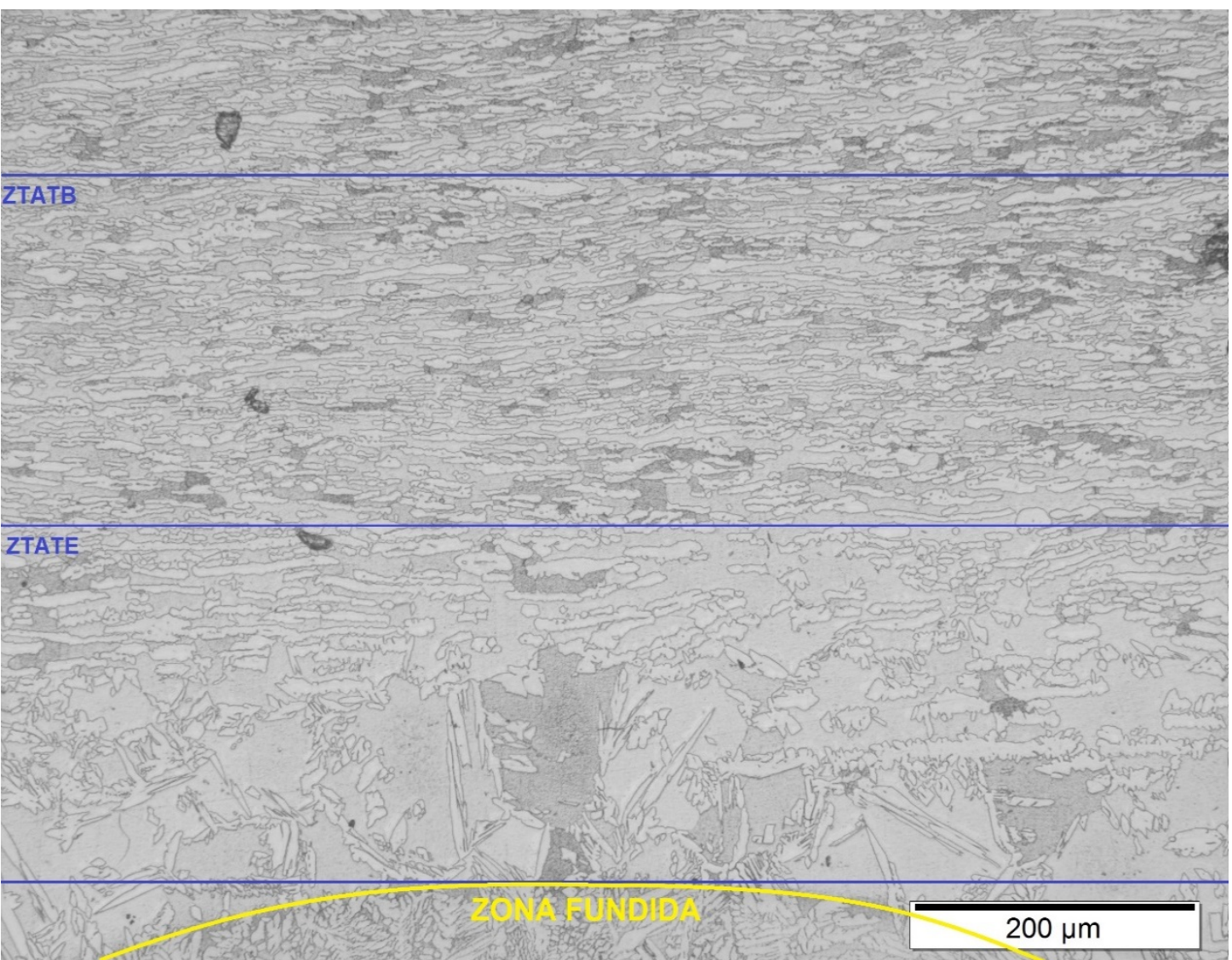

Figura 7.37: Imagens obtidas por microscopia da amostra 2205G15. Superior com um aumento de 100x, inferior com um aumento de 200x.

A função do nitrogênio nos AIDs é estabilizar a fase austenítica, e durante a soldagem esse alto teor de nitrogênio promove mais a estabilização da austenita na ZTA no AID 2205, em comparação com o lean duplex 2304 (admitindo-se o mesmo aporte térmico), assim os grãos de austenita nucleiam e crescem durante o ciclo de resfriamento. A porcentagem da austenita na ZTA diminui com a diminuição do aporte de calor utilizado, sendo, portanto, uma função do tempo $\Delta t_{12-8}$ 
Existe uma imprecisão para essas medidas apresentadas das frações de fase, inerentes ao processo experimental, devido ao contraste obtido nas imagens das amostras, que torna complexa a tarefa de obter tais dados. Como o ataque químico realizado é o mesmo para todas as amostras, essa imprecisão, em princípio, se mantém uniforme e igualmente distribuída para as amostras.

Novamente, o modelo numérico demonstrou a capacidade de prever os ciclos térmicos envolvidos na ZTA - tanto de temperatura alta quando de temperatura baixa - podendo assim, ser realizada uma estimativa da extensão da mesma, conhecendo-se o material empregado.

\section{Amostra 2304G15}

Por fim, com relação à última amostra a ser avaliada, os ciclos térmicos obtidos através da simulação numérica, está apresentado a seguir, na figura 7.38.

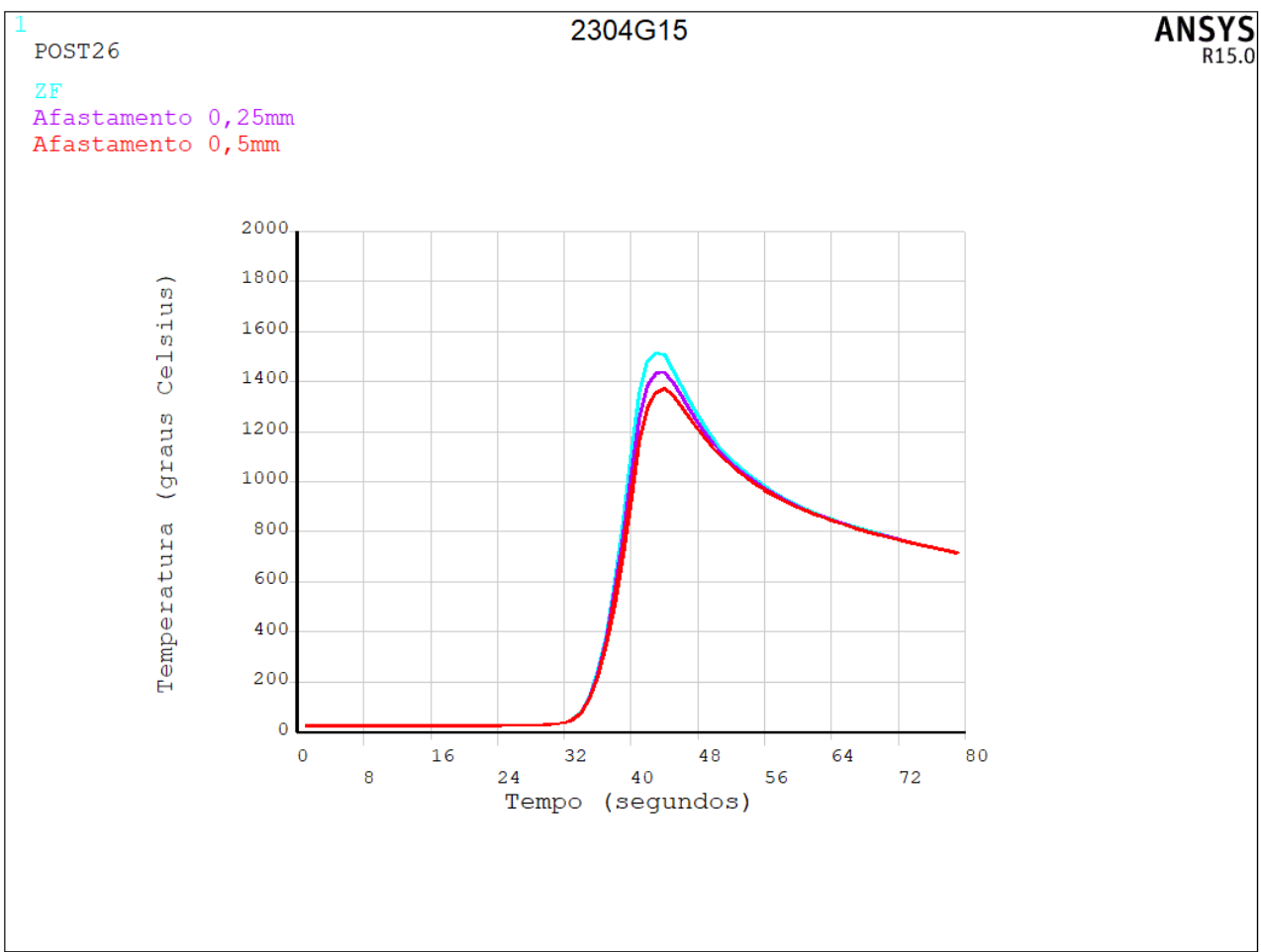

Figura 7.38: Ciclos térmicos simulados para a amostra 2304G15.

O perfil dos ciclos térmicos da presente amostra, como já esperado, é análogo ao da anterior, apresentando taxas de resfriamento dos 3 pontos abordados também similares, e medindo os tempos de resfriamento para cada um dos pontos no intervalo de interesse $\left(1200\right.$ a $\left.800^{\circ} \mathrm{C}\right)$, temos: 
Para a Zona Fundida: $\Delta t_{12-8}=19,00 s\left(\mathrm{~T}_{\text {máx }}=1470^{\circ} \mathrm{C}\right)$

Para o ponto afastado $0,25 \mathrm{~mm}: \Delta t_{12-8}=19,75 \mathrm{~s}\left(\mathrm{~T}_{\text {máx }}=1435^{\circ} \mathrm{C}\right)$

Para o ponto afastado 0,5mm: $\Delta t_{12-8}=20,25 s\left(\mathrm{~T}_{\text {máx }}=1365^{\circ} \mathrm{C}\right)$

onde, os tempos de resfriamento encontrados são similares aos obtidos para a amostra anterior, com o mesmo aporte térmico empregado. Para a quantificação de fase, através da contagem de fases por imagem (FIG. 7.39), apenas considerando as devidas distâncias adotadas os resultados foram:

_para o primeiro 0,25mm, uma ZTATE, foi determinado 69\% de ferrita; _para o segundo $0,25 \mathrm{~mm}$, ZTATB, foi determinado $62 \%$ de ferrita.

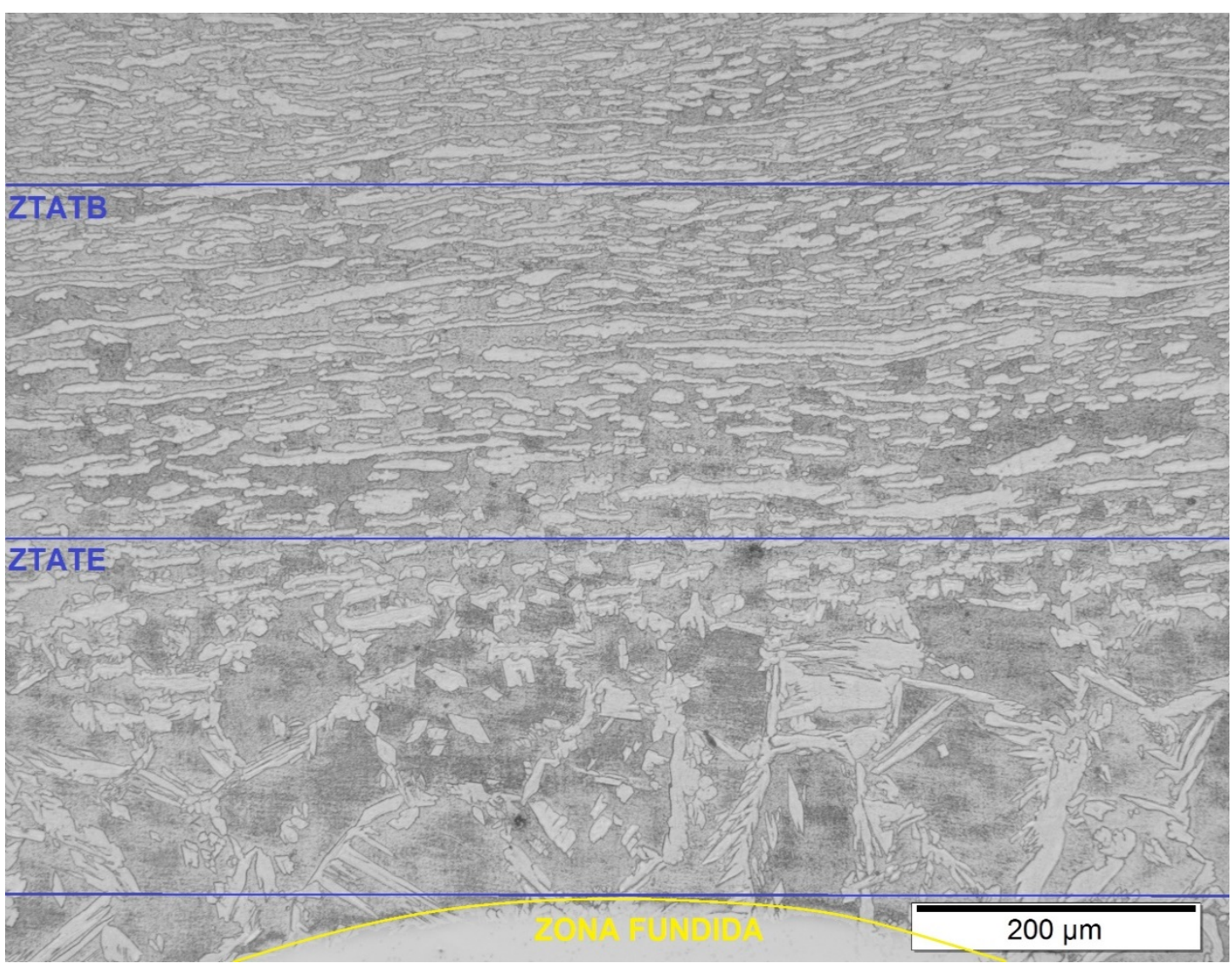

Figura 7.39:Imagens obtidas por microscopia da amostra 2304G15. Superior com um aumento de 100x, inferior com um aumento de 200x.

O comportamento do crescimento de grão proporcional aos aportes de calor (e aos tempos $\Delta t_{12-8}$ ) durante o processo de soldagem, mostra que o crescimento do grão da ferrita é muito mais susceptível para aço inoxidável lean duplex do que o aço inoxidável duplex. As inclinações da relação tamanho de grão da ferrita vs aporte de calor (taxas de resfriamento) são maiores no aço lean duplex. O aumento da porcentagem da fase austenítica quando o tempo 
$\Delta t_{12-8}$ também aumenta, é evidenciado no aumento do tamanho dos grãos de austenita. As agulhas de austenita Widmanstätten se vão-se tornando mais espessas e os grãos de austenita intergranular também exibem um crescimento proporcional ao tempo de resfriamento $\Delta t_{12-8}$.

Os resultados apresentados para todas as 4 amostras aqui avaliadas, mostram que existe ao menos uma fração mínima de austenita na ZTA, usando aportes térmicos de 1,5 e 2,5kJ/mm. Esta fração mínima corresponde a um valor acima de 30\%, como recomendado para aplicação satisfatória em aços duplex (JANA, 1992), sem grandes evidências da ocorrência da fase sigma. Lembrando que o modelo numérico não leva em conta transformação de fase e não simula os processos físicos que acontecem na poça de fusão, considerando todo o material como sendo sólido em todos os instantes de tempo.

Assim, uma vez devidamente calibrado, o modelo pode ser ajustado para outros tipos de situações, envolvendo a mudança dos materiais empregados e do processo de soldagem. Nesta subseção 7.3, foram comparados dados experimentais com os ciclos térmicos obtidos através do modelo numérico, observando-se uma boa concordância entre ambos. 


\section{Conclusões}

Um estudo relacionado à obtenção de ciclos térmicos de soldagem de aços inoxidáveis duplex foi realizado neste trabalho com base em observações experimentais e simulações numéricas. Ao usar a simulação numérica, foi possível prever o histórico térmico e avaliar os ciclos térmicos para calcular localmente os tempos de aquecimento e resfriamento ocorridos durante a soldagem. Assim, os resultados podem ser descritos a seguir:

1) A metodologia proposta utiliza o modelo numérico desenvolvido, mostrando-se adequada para prever características importantes do processo de soldagem, como os ciclos térmicos e o perfil da linha de fusão de juntas soldadas, visto que a distribuição de temperaturas entre as simulações e os experimentos apresentaram boa concordância;

2) O efeito das geometrias empregadas no presente estudo revelou um impacto direto sobre os resultados, na busca por um mínimo sistema a ser simulado, visando reproduzir o sistema real. A geometria de 150x150mm mostrou-se inadequada quanto à essa representação e sua devida reprodutibilidade, uma vez que a mesma apresentou o "efeito de borda”;

3) A fração de austenita permaneceu na faixa recomendada para a aplicação dos aços inoxidáveis duplex aqui estudados;

4) Nenhuma evidência da formação da fase sigma foi observada em cada uma das condições de soldagem avaliadas. De fato, os resultados calculados da simulação numérica demonstraram que as taxas de resfriamento sempre permaneceram acima das descritas como críticas para a precipitação da fase sigma;

5) Neste estudo, um modelo numérico proposto foi capaz de prever, entre outros, as velocidades locais de aquecimento e resfriamento ocorridas durante a soldagem de aços inoxidáveis duplex, o que possibilita avaliar seus efeitos nas características microestruturais em diferentes regiões afetadas pela solda. Os resultados obtidos indicam que a metodologia proposta pode ser 
utilizada como uma ferramenta importante em estudos não só relacionados à soldagem destes materiais, mas também para outras ligas de metais. 


\section{9}

\section{Sugestão para Trabalhos Futuros}

Ainda existe muito a ser desenvolvido no campo envolvendo a análise térmica do processo de soldagem, em especial para os aços duplex. Para isso são necessários aprimoramentos nos modelos numéricos, mais informações a respeito das propriedades físicas dos aços duplex em altas temperaturas e estudos do comportamento termomecânico do modelo com acoplamento e mudança de fase. Como sugestão de futuros trabalhos, se propõe:

1. Levantamento das propriedades termodependentes - como condutibilidade térmica e calor específico, para os aços duplex sob altas temperaturas, para melhorar a precisão dos resultados obtidos através dos modelos numéricos;

2. Representação do coeficiente de convecção térmica para as faces da peça através de funções dependentes da temperatura;

3. Incorporação no modelo tridimensional de efeitos de acoplamento internos, como os associados ao processo de transformação de fase, que se desenvolve durante o processo de soldagem. 


\section{Referências Bibliográficas}

ADAK, M.; MANDAL, N.R. Thermo-Mechanical Analysis of Plates Undergoing Line Heating Pseudolinear Equivalent Constant Rigidity System. Transactions Society of Naval Architects and Marine Engineers, v. 111, p. 353 - 361, 2003.

AGUIAR, I.V.; ESCOBAR, D.P.; SANTOS, D.B.; MODENESI, P.J. Microstructure characterization of a duplex stainless steel weld by electron backscattering diffraction and orientation imaging microscopy techniques. Revista Matéria, v.20, n.01, pp. 212-226; 2015.

ALMEIDA, D.; QUEIROZ, A.V.; XAVIER, C.R.; MARCELO, C.J.; CASTRO, J. A.; OLIVEIRA, E.M.; Modelo duplo-elipsoide acoplado a volumes finitos para simular a soldagem GMAW do aço inoxidável duplex SAF 2205. Tecnologia em Metalurgia Materiais e Mineração, São Paulo, 2016.

AMERICAN SOCIETY OF MATERIALS. Properties and Selection: Iron, Steels and High Performance Alloys. Specialty Steels and Heat-Resistant Alloys, Wrought Stainless Steels, vol. 1, 2002.

ASM - Metals Handbook. Welding, Brazing and Soldering, ASM International, vol. 6,1993.

ASM - Gas-metal arc welding. Welding Handbook. 2.ed., vol. 6, p. 569-581, 1994.

ASM - Metals Handbook, ASM International, 8th Edition, vol. 8, 1966.

ATAMERT*, S.; KING, J.E.; Elemental partitioning and microstructural development in duplex stainless steel weld metal. Acta Metall. Mater., vol. 39, ${ }^{\circ}$ 3, p. 273-285, 1991.

ATAMERT, S.; KING, J.E. Super duplex stainless steels - part 1 heat affected zone microestructures. Materials Science and Technology, vol. 8, n. 10, p. 896911, 1992.

AWS - American Welding Society. Welding Handbook, Welding Process, Miami, USA, vol. 2, 1998.

AWS - American Welding Society. Welding Handbook, vol. 4, 8 ed., Miami, USA, 1997.

BADJI, R.; BOUABDALLAH, M.; BACROIX, B.; KAHLOUN, C.; BELKESSA, B.; MAZA, H. Phase transformation and mechanical behavior in annealed 2205 duplex stainless steel welds. Materials Characterization, 59(4): 447-453, 2008. 
BARAN, N.M. Finite element analysis on microcomputers. McGraw-Hill, Inc., p. $140,1988$.

BISWAS, K.; Notch tip deformation and J-integral analysis for implant weldability test specimen. International Journal of Fracture, 67: 99-116, 1994.

BONIFAZ, E.A. Finite Element Analysis of Heat Flow in Single-Pass Arc Welds, Welding Journal, vol. 79, p. 121s-125s, 2000.

BONAVINA, L.F.; MARTINS, M. Efeito da temperatura na microestrutura do aço ASTM A890 gr 6A. 58 Congresso anual da ABM, Rio de Janeiro, RJ. Julho de 2003.

BORSATO, K.S. Caracterização microestrutural e de propriedades mecânicas de chapas espessas de aço inoxidável duplex UNS S31803, submetidos a ciclos térmicos de soldagem. Tese de doutorado. UFSC, Santa Catarina. 2001.

BORSATO, K.S. Avaliação das propriedades mecânicas, microestrutura e cinética de precipitação da fase sigma do aço inoxidável duplex UNS S31803. Curitiba, Paraná. 2006.

BRANDI, S.D. Estudo da Soldabilidade dos Aços Inoxidáveis Duplex DIN W. 1.4462 (UNS S31803). Tese de Doutorado, USP, São Paulo, 1992.

BRANDI, S.D. Aplicação da norma ASTM A923 prática a para identificação de fases intermetálicas em junta soldada de aço inoxidável superduplex 2507. Escola Politécnica da USP, Engenharia Metalúrgica e de Materiais, 2008.

CALLIARI, I.; ZANESCO, M.; RAMOUS, E. Influence of isothermal aging on secondary phases precipitation and toughness of a duplex stainless steel SAF 2205. Journal of Materials Science, 41(22): 7643-7649, 2006.

CAPRICCIOLI, A.; FROSI, P. Multipurpose ANSYS FE procedure for welding processes simulation. Fusion Engineering and Designing, 84, p. 546-553, 2009.

CASTRO, J.A.; OLIVEIRA, E.M.; ALMEIDA, D.S.S.; FONSECA, G.S.; XAVIER, C.R. Effects of Local Heat Input Conditions on the Thermophysical Properties of Super Duplex Stainless Steels (SDSS). Materials Research, 9 pgs, 2017.

CHARLES, J.; FARIA, R.A. Aços inoxidáveis duplex e aplicações em óleo e gás: uma revisão incluindo a nova oferta da Arcelor Mittal, 2008.

CHAWLA, S.L.; GRUPTA. R.K. Materials Selection for corrosion control. Metals Park, O.H. American Society for Metals, 1995.

CHEN, T.H.; YANG, J.R. Microstructural characterization of simulated heat affected zone in a nitrogen-containing 2205 duplex stainless steel. Materials Science and Engineering A, 338(1-2): 166-181, 2002. 
CHRISTENSEN, N.; DAVIES, V.D.L.; GJERMUNDSEN, K. Distribution of temperatures in arc welding. British Welding Journal, vol. 12, n. 2, p. 54-75, 1965.

CUNHA, L.J.G. Solda: Como, Quando e Por Quê. Ed. D. C. Luzzatto, 260p, 1989.

DAHA, M.A.; NASSEF, G.A.; ABDALLAH, I.A. Numerical modeling of heat transfer and fluid flow in keyhole plasma arc welding of dissimilar steel joints. International Journal of Engineering Science and Technology (IJEST), vol. 4, n. 2, 2012.

DAKHLAOUI, R.; BRAHAM, C.; BACZMANSKI A.; WRONSKI S.; WIERBANOSKI, K.; OLIVER, E.C. Analyze Of phase's mechanical behaviour of duplex stainless steels by X-ray and neutron diffraction. Grado, Italy. 2007.

DUPONT, J.N.; MARDER, A.R. Thermal efficiency of arc welding processes. Welding research supplement, p. 406s-416s, 1995.

EAGAR, T.W.; TSAI, N.S. Temperature Fields Produced by Travelling Distributed Heat Sources. Welding Journal, vol. 62, n. 12, p. 346-355, 1983.

EGHLIMI, A.; SHAMANIAN, M.; RAEISSI, K. Dilution and ferrite number prediction in pulsed current cladding of super-duplex stainless steel using RSM. Journal of Materials Engineering and Performance, vol. 22, n. 12, p. 3657-3664, 2013.

FOLKHARD, E. Welding Metallurgy of Stainless Steels. Springer Verlar, Wien. New York, 1988.

FONSECA, G.S.; OLIVEIRA, P.M.; DINIZ, M.G.; BUBNOFF, D.; CASTRO, J.A. Sigma Phase in Superduplex Stainless Steel: Formation, Kinetics and Microstructural Path. Materials Research, 20(1): 249-255, 2017.

FRANCIS, J.D. Welding Simulations of Aluminium Alloy Joints by Finite Element Analysis, Tese de Mestrado, Virginia Polytechnic Institute and State University, Virginia, USA, 2002.

GENTIL, V. Corrosão, 4 Ed., Rio de Janeiro, LTC Editora, 2003.

GOLDAK, J.; CHAKRAVARTI, A.; BIBBY, M. A New Finite Element Model for Welding Heat Sources. Metallurgical Transactions B, vol. 15B, p 299 - 305, 1984.

GOLDAK, J.; BIBBY, M.; MOORE, J.; HOUSE, R.; PATEL, B. Computer Modeling of Heat Flow in Welds. Metallurgical Transactions B, vol. 17B, p. 587600, 1986.

GUNN, R.N. Duplex stainless steels. Microstructure, properties and applications. Cambridge - England: Abington Publishing, 2003. 
GUNN, R.N. Duplex Stainless Steels: Microstructures, Properties and Applications. Cambridge: Abington Publishing. 204p, 1997.

HALMOY, E. The pressure of the arc acting on the weld pool, Arc Physics and Weld Pool Behaviour[Proc. Conf.]. The Welding Institute, p. 259-266, 1979.

HEIPER, C.R.; ROPER, J.R. Mechanism for minor element effect on GTA fusion zone geometry. Welding Journal, vol. 61, n. 4, p. 97s-102s, 1982.

HERTZMAN, S.; ROBERTS, W.; LINDENMO, M. Microestructure and properties of nitrogen alloyed duplex stainless steel after welding treatments. In: Conference Duplex Stainless Steels'86. Nederlands, p. 257-267, 1986.

HUANG, C.-S.; SHIH, C.-C. Effects of nitrogen and high temperature aging on phase $\sigma$ precipitation of duplex stainless steel. Materials Science and Engineering A, v. 402, p. 66-75, 2005.

IMOA, The International Molybdenum Association (IMOA). Practical Guidelines For The Fabrication of Duplex Stainless Steels. London - UK, 64 p, 2009.

INCROPERA, F.P.; DEWITT, D.P.; Fundamentos de transferência de calor e de massa, $4^{0}$ Ed., Rio de Janeiro: LTC - Livros Técnicos e Científicos Editora, S/A, 1998.

JANA, S.; J. Mater. Process. Technol., 33, 247-261, 1992.

JIANG, W.; YAHIAOUI, K.; HALL, F. R.; LAOUI, T.; Finite element simulation of multipass welding: full three-dimensional versus generalized plane strain or axisymmetric models. J Strain Analysis, vol. 40, n. 6, pp. 587-597, 2005.

KIVINEA, E.I.; HANNERZ, N.E. The properties of Gleeble simulated heat affected zone of SAF 2205 and SAF 2507 duplex stainless steels. In: Conference Duplex Stainless Steels'94, England, paper 7, 1994.

KOBAYASHI, D.; WOLYNEC, S. Evaluation of the low corrosion resistance phase formed during the sigma phase precipitation in duplex stainless steels. Materials Research, vol. 2, n. 4, p. 239-47, 1999.

KOTECKI, D.J. Ferrite control in duplex stainless steel weld metal. Welding Journal. v. 65, n. 10, p. 273s-278s, 1986.

KOU, S. Welding Metallurgy. John Wiley \& Sons, Inc., publication. PP 460, 2003.

LILJAS, M. Welding metallurgy for duplex stainless steels. I. Acciaio Inossidabile (Italy), vol. 63, n. 2, p. 2-10, 1996.

LILJAS, M.; The welding metallurgy of duplex stainless steels. Proceedings. In: Duplex Stainless Steels’94. Escócia: TWI, paper, 1994. 
LINDBLOM, B.E.S.; LUNDQVIST, V.; HANNERZ, N.E. Grain growth in HAZ of duplex stainless steels. In: Conference Duplex Stainless Steels'91, France, p. 373-381, 1991.

LINTONA, V.M., LAYCOCK, N.J., THOMSEN, S.J., KLUMPERS, A. Failure of a Super Duplex Stainless Steel Reaction Vessel, Elsevier, Engineering Failure Analysis 11, 243-256, 2004.

LIOU, H-Y.; HSIEH, R-I.; TSAI, W-T. Microstructure and pitting corrosion in simulated heat-affected zones of duplex stainless steels. Materials Chemistry and Physics, 74(1): 33-42, 2002.

LIPPOLD, J.C.; VAROL, I.; BAESLACK, W.A. III. The influence of composition and microstructure on the HAZ toughness of duplex stainless steels at $-20^{\circ} \mathrm{C}$. Welding Journal, 73(4): 75-79, 1994.

LIPPOLD, J.C.; KOTECKI, D.J. Welding Metallurgy and Weldability of Stainless Steels. John Wiley \& Sons, Inc, 2005.

LITTLE, G.H.; KAMTEKAR, A.G. The effect of thermal properties and weld efficiency on transient temperatures during welding. Comput Struct; 68: 157-65, 1998.

LONDOÑO, A.J.R. Estudo da Precipitação de Nitreto de Cromo e Fase Sigma por Simulação Térmica da Zona Afetada pelo Calor na Soldagem Multipasse de Aços Inoxidáveis Duplex. Dissertação (Mestrado), Escola Politécnica da Universidade de São Paulo, 1997.

LONDOÑO, A.J.R. Precipitação das fases intermetálicas e austenita secundária na ZAC de soldagens multipasse de aços inoxidáveis duplex. Tese (Doutorado) | Escola Politécnica da Universidade de São Paulo, 2001.

LUENGAS, L.O. Simulação Física e Caracterização Microestrutural e Mecânica da Zona Termicamente Afetada (ZTA) em Aços Inoxidáveis Duplex. Tese (Doutorado), Departamento de Engenharia Química e de Materiais, PUC-Rio, 2017.

MADENCI, E.; GUVEN, I. The Finite Element Method and Applications in Engineering using ANSYS. Springer, Berlin, 2005.

MAGNABOSCO, R.; Kinetics of sigma phase formation in a Duplex Stainless Steel. Materials Research, 12(3): 321-327, 2009.

MARQUES, P.V.; MODENESI P.J.; BRACARENSE, A.Q. Soldagem: Fundamentos e tecnologia. Belo Horizonte: Ed. UFMG, p. 51-125, 2007.

MARTINS, M.; CASTELETTI, L.C. Obtenção e caracterização dos Aços inoxidáveis duplex e super duplex. FS - Fundição e Serviços, vol. 17, São Paulo, 2007. 
MESSER, B.; OPREA, V.; WRIGHT, A. Duplex Stainless Steel Welding: Best Practices. Stainless Steel World, December 2007.

MIG/MAG Welding, Svetsaren, vol. 58, n² 2, 2003

MODENESI P.J.; MARQUES, P.V. Soldagem I - Introdução aos processos de soldagem, 2000.

MODENESI, P.J. Soldabilidade dos aços inoxidáveis. Associação Brasileira de Soldagem, 2001.

MODENESI, P.J. Introdução à Física do Arco Elétrico E sua Aplicação na Soldagem dos Metais. UFMG, Departamento de EngenhariaMetalúrgica e de Materiais. 146 pgs, 2007.

McGUIRE, M. Stainless Steels for Design Engineers, ASM International, 2008.

MSC. Software Corporation, Msc. Marc Volume A: Theory and User Information, Version 2005.

MUNDRA, K.; DEBROY, T; ZACHARIA, T.; DAVID, S.A. Role of Thermophysical Properties in Weld Pool Modeling. Welding Journal, n. 9, p. 313320, 1992.

MUTHUPANDI, V.; SRINIVASAN, P.B.; SESHADRI, S.K.; SUNDARESAN, S. Effect of weld metal chemistry and heat input on the structure and properties of duplex stainless steel welds. Materials Science and Engineering A, 358(1-2): 916, 2003.

NASSAU, M.L. Le soudage des aciersaustenito-ferritiques au Cr-Ni-Mo. Soudage et Techniques Connexes, 37(1-2), p. 66-70, 1983.

NGUYEN, N.; OHTA, A.; MATSUOKA, K.; SUZUKI, N.; MAEDA, Y. Analytical solutions for transient temperature of semi-infinite body subjected to 3D moving heat sources. Weld Res., 3, p. 265s-274s, 1999.

NOBLE, D.N. Selection of wrought duplex stainless steels. In: ASM Metals Handbook. ASM International, USA, vol. 6, p. 1217-1232, 1996.

NOWACKI, J.; LUKOJC, A. Structure and properties of the heat-affected zone of duplex steels welded joints. Journal of Materials Processing Technology, 164165: 1074-1081, 2005.

NOWACKI, J.; LUKOJC, A. Microstructural transformations of heat affected zones in duplex steel welded joints. Materials Characterization, 56(4-5): 436-441, 2006.

NILSSON, J.-O. Physical metallurgy of duplex stainless steels. In: Proceedings Duplex Stainless Steel 97, 5th World Conference, Maastricht, Holanda. Outubro 1997, p. 73-82. 
OLSSON, K. Weld surfacing with duplex stainless steel strip electrodes. In: Conference Duplex Stainless Steels'86, The Hauge - The Netherlands, 1986. Proceedings. Nederlands Institut Voor Lastechniek, p. 331-339, 1986.

OLSSON, J.; LILJAS, M. 60 Years of Duplex Stainless Steel Applications. Avesta Sheffield AB, Sweden. Acom n. 2, p. 96, 1996.

PADILHA, A.F.; PLAUT, R.L. Phase transformation and microstructure. In: ALVARES-ARMAS, I.; DEGALLAIX-MOREULI, S. (Ed.) Duplex Stainless Steels. London: ISTE Ltd and John Wiley \& Sons, vol. 1, 2009, cap. 3, p. 115139.

PAPAZOGLOU, V.J.; MASUBUCHI, K. Numerical analysis of thermal stresses during welding including phase transformation effects. Journal of Pressure Vessel Technology, 104: 198-203, 1982.

PARDAL, J.M. Efeitos dos Tratamentos Térmicos nas Propriedades Mecânicas, Magnéticas e na Resistência a Corrosão de Aços Inoxidáveis Superduplex. Juan Manuel Pardal. - Niteroi, RJ: [s.n.], 2009.

PARDAL, J.M. et al. Caracterização e avaliação da resistência à corrosão na soldagem de tubulação de aço inoxidável duplex uns s31803 pelo processo a arco submerso. Soldagem Inspeção, Scielo, vol. 16, p. 310-321, 12. ISSN 0104-9224, 2011.

PAVELIC, V.; TANBAKUCHI, R.; UYEHARA O.A.; MYERS, P.S. Experimental and computed temperature histories in gas tungsten arc welding of thin plates. Welding Journal Research Supplement, vol. 48, pp. 295s-305s, 1969.

RAMIREZ, A.J.; LIPPOLD, J.C.; BRANDI, S.D. The Relationship between Chromium Nitride and Secondary Austenite Precipitation in Duplex Stainless Steels, Metallurgical and Materials Transactions A, vol. 34A, p. 1575- 1597, 2003.

RAYNOR, G.V.; RIVLIN, V.G. Phase equilibria in iron ternary alloys. The Institute of Metals: London, p. 316-32. 1988.

ROBERGE, P.R. Handbook of Corrosion Engineering. McGraw-Hill Handbooks, p.1-54, 2000.

ROSENTHAL, D. The theory of moving sources of heat and its applications to metal treatments. Transactions of the ASME, vol. 68, p 849-866, 1946.

RYKALIN, R.R. Energy sources for welding. Welding in the World, vol. 12, pp. 227-248, 1974.

SANDVIK; Material Datasheet SAF 31803-ENG, Sandvik, Fev 2015.

SANDVIK; Material Datasheet SAF 2304-ENG, Sandvik, Fev 2015. 
SANDVIK, Welding Practice for the Sandvik Duplex Stainless Steels SAF 2304, SAF 2205 and SAF 2507, Workshop Petrobras, 2009.

SAQUIB, M.; UNTAWALE, S.P. Measuring the process efficiency of controlled welding processes. International Journal of Instrumentation, Control and Automation (IJICA), ISSN: 2231-1890, vol. 1, Iss-3, 4, 2012.

SCHWEITZER, P.A. Fundamentals of metallic Corrosion. Atmospheric and media Corrosion of Metals. Corrosion Engineering Handbook, CRC. New York, 1996.

SCOTTI, A.; PONOMAREV, V. Soldagem MIG/MAG - Artliber Editora - 2008.

SEDRIKS, A.J. Corrosion of Stainless Steels, 2nd edition, John Wiley \& Sons, New York, 1996.

SENATORE, M.; FINZETTO, L.; PEREA, E. Estudo comparativo entre os aços inoxidáveis duplex e os inoxidáveis AISI 304L/316L. REM: Revista Escola de Minas, Ouro Preto, 60(1): 175-181. 2007.

SMITH, W.F. Structure and Properties of Engineering Alloys. McGraw-Hill Publishing Co, 1981.

SOLOMON, H.D.; DEVINE, T.M. A tale of two fases. Conference Duplex Stainless Steel’s 82-Proceedings, St. Louis, Estados Unidos, p. 693-756. 1982.

SOUZA, L.R. Efeitos do curvamento por indução eletromagnética nas propriedades mecânicas, magnéticas e na resistência à corrosão de tubos de aço inoxidável duplex UNS S31803. Dissertação (Mestrado) - Centro Universitário Estadual da Zona Oeste, 2015.

STILL, J.R. The use of duplex stainless steel in the offshore oil and gas industry part 2. Welding \& Metal Fabrication, Aug - Sep, p. 331-339, 1994.

TAVARES, S.S.M.; PARDAL, J.M.; LIMA, L.D.; BASTOS, L.N.; NASCIMENTO, A.M.; SOUZA, J.A. Characterization of microstructure, chemical composition, corrosion resistance and toughness of a multipass weld joint of superduplex stainless steel UNS S32750. Materials Characterization, 58(7): 610-616, 2007.

TOPOLSKA, S.; LABANOWSKI, J. Effect of microstructure on impact toughness of duplex and superduplex stainless steels. Journal of Achievements in Materials and Manufacturing Engineering, 36: 142-149, 2009.

TSAI, N.S.; EAGAR, T.W. Distribution of the heat and current fluxes in gas tungsten arcs. Metallurgical Transactions B, vol. 16B, p. 841 - 846, 1985.

USHIO, M.; WU, C.S. Mathematical Modeling of Three-Dimensional Heat and Fluid Flow in a Moving Gas Metal Arc Weld Pool. Metallurgical and Materials Transactions B, vol. 28B, pp, 509-516, 1997. 
VASCONCELLOS P.G. Soldagem em campo de tubos de aço inox duplex e superduplex. Dissertação (Mestrado). Universidade Estadual do Norte Fluminense. Rio de Janeiro. 2008.

VAROL. I. Microestructure/Property Relationships in the weld heat affected zone of duplex stainless steels. Columbus-Ohio, p.261. Tese de Doutorado Department of Welding Engineering, The Ohio State University, 1992.

VAROL*, I.; LIPPOLD, J.C.; BAESLACK, W.A.; III, W.A. Welding of duplex stainless steels. Key Engineering Materials, vol. 69-70, p. 217-252, 1992.

WU, C.S.; CHEN, M.A.; LI, S.K. Analysis of excited droplet oscillation and detachment in active control of metal transfer. Elsevier, Computational Materials Science 31, p. 147-154, 2004.

XAVIER, C.R.; CAMPOS, M.F.; CASTRO, J.A. Numerical Method Applied to Duplex Stainless Steel Welding. Iron making and Steel making, vol. 40, n. 6, 2013.

XAVIER, C.R.; DELGADO, H.G. Jr.; CASTRO, J.A.; FERREIRA, A.F. Numerical Predictions for the Thermal History, Microstructure and Hardness Distributions at the HAZ During Welding of Low Alloy Steels. Materials Research, 19(3): 520-533, 2016.

XIAOJUN, J.; LIXING, H. Finite element analysis of modeling residual stress distribution in all position duplex stainless Steel welded pipe. Materials Science Technology, vol. 20, n. 4, p. 387-390, 2004.

YANG, Y.; YAN, B.; LI, J.; WANG, J. The effect of large heat input on the microstructure and corrosion behavior of simulated heat affected zone in 2205 duplex stainless steel. Corrosion Science, 53(11): 3756-3763, 2011.

YIMING GANG: Chinese Manual Book of Stainless Steel. Metallurgy Industrial Press, Beijing, 1992.

ZACHARIA, T.; DAVID, S.A.; VITEK, J.M. Effect of evaporation and temperature dependent material properties on weld pool development. Metallurgical Transactions B, vol. 22B, p. 233-241, 1991. 